\title{
nordon
}

Nordiska ministerrådet

Planer och budget 2014 


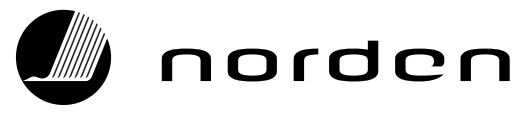





\section{Nordiska ministerrådet Planer och budget 2014}


Nordiska ministerrådet Planer och budget 2014

ISBN 978-92-893-2665-0

http://dx.doi.org/10.6027/ANP2013-778

ANP 2013:778

(C) Nordisk Ministerråd 2013

Omslagsfoto: Scanprint as/Nordiska ministerrådet

Tryk: Scanprint as

Oplag: 500

Printed in Denmark

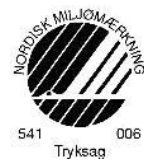

\section{Det nordiske samarbejde}

Det nordiske samarbejde er en af verdens mest omfattende regionale samarbejdsformer. Samarbejdet omfatter Danmark, Finland, Island, Norge og Sverige samt Færøerne, Grønland og Åland.

Det nordiske samarbejde er både politisk, økonomisk og kulturelt forankret, og er en vigtig medspiller i det europæiske og internationale samarbejde. Det nordiske fællesskab arbejder for et stærkt Norden i et stærkt Europa.

Det nordiske samarbejde ønsker at styrke nordiske og regionale interesser og værdier i en global omverden. Fælles værdier landene imellem er med til at styrke Nordens position som en af verdens mest innovative og konkurrencedygtige regioner.

\section{Nordisk Ministerråd}

Ved Stranden 18

1061 København K

Telefon (+45) 33960200

\section{www.norden.org}


Den totale udgiftsramme for Nordisk Ministerråds budget for virksomhedsåret 2014

$\begin{array}{lr}\text { Lasevejledning } & 16\end{array}$

$\begin{array}{ll}\text { Nordisk Ministerråds planer for virksomhedsåret } 2014 & 17\end{array}$

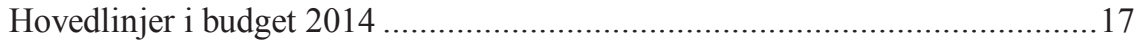

Prioriteringsbudget $\quad 29$

Generel Indledning ...................................................................29

7-8001-2 NordMin 30

7-8002-2 Fler unga i arbete i Norden och arbetsmarknadsmötet 31

7-8003-2 Förbättrade emissionsinventeringar av kortlivade klimatpåverkande luftöroreningar 31

7-8004-2 Lärande på arbetsplats $\quad 32$

7-8005-2 Den nordiska spellistan $\quad 33$

7-8006-2 Välfärdsvakten $\quad 34$

7-8007-2 Bioekonomi-satsningen $\quad 35$

8-8110-1 Testcenter 36

7-8111-2 Uddannelse og forskning inden for grøn vækst 36

7-8112-1 Elmarknaden 38

7-8113-2 Grønne tekniske normer og standarder - Norden som
standardmaker

7-8114-2 Grønt offentligt indkøb $\quad 40$

7-8115-1 Utveckla tekniker och metoder för avfallshantering 40

7-8116-2 Främja integation av miljö och klimat i utvecklingssamarbetet 42

7-8117-1 Samordning och förstärkt finansiering av gröna investeringar och

$\begin{array}{ll}\text { företag } & 43\end{array}$

7-8210-2 Hållbar nordisk välfärd 44

7-8211-1 Fælles studie af den nordiske velfærdsmodels udfordringer $\quad 45$

7-8212-2 Välfärd och kost $\quad 45$

7-8310-2 Klimavenligt byggeri 47

7-8311 Kultur og kreativitet - KreaNord initiativet 47

7-8312-2 Offentligt-privat-partnerskab om planteforædling i Norden 49

$\begin{array}{ll}7-8313-2 \text { Ny Nordisk Mad } & 50\end{array}$

7-8401-1 Kennedycenter (Nordic Cool) 50

7-8402-1 Integrering av jämställdhetsperspektiv 51 


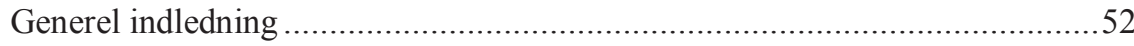

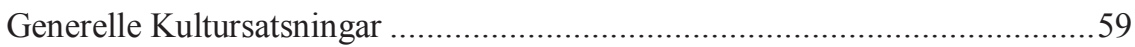

1-2203-1 Dispositonsmidler Kultur $\quad 59$

1-2204-1 Nordisk Kulturforum $\quad 59$

1-2205-2 Nordisk Kulturfond $\quad 60$

1-2206-2 Nordisk Råds priser $\quad 61$

1-2207-1 Kulturministrenes globaliseringsindsatser 62

1-2208-1 Strategiska satsningar 63

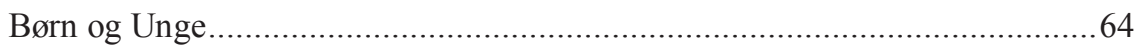

1-2212-2 Nordisk Børne- og Ungdomskomité (NORDBUK) 64

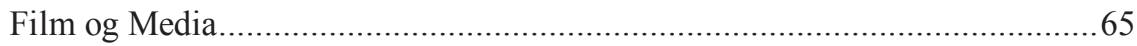

1-2221-2 Nordisk computerspilprogram $\quad 65$

1-2222-2 Nordisk Film- og TV-fond 65

1-2223-2 Nordisk Journalistisk Efteruddannelse 66

$\begin{array}{ll}1-2228-3 \text { NORDICOM } & 67\end{array}$

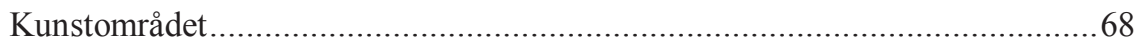

1-2251-2 Kultur- og Kunstprogrammet $\quad 68$

1-2253-2 Nordisk oversættelsesstøtte $\quad 69$

1-2254-2 Nordiskt-baltiskt mobilitetsprogram för Kultur 70

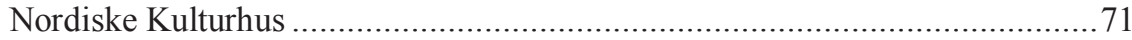

1-2270-3 Nordens hus i Reykjavik $\quad 71$

1-2272-3 Nordens hus på Färöarna $\quad 72$

1-2274-3 Nordens Institut på Åland

1-2277-3 Nordens Institut på Grönland (NAPA) 73

1-2548-3 Kulturkontakt Nord $\quad 74$

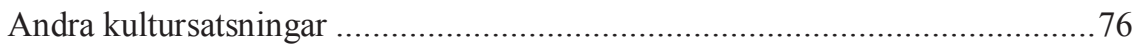

1-2234-4 Samiskt samarbete $\quad 76$

Fiskeri og havbrug, Jordbrug, Levnedsmidler og Skovbrug 77

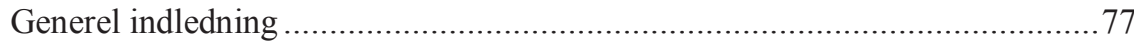

3-6420-2 Ny nordisk mad $\quad 81$

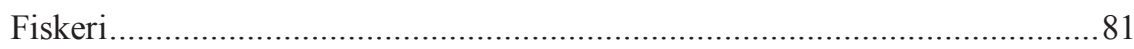

3-6610-1 Projektmidler - Fiskeri $\quad 81$

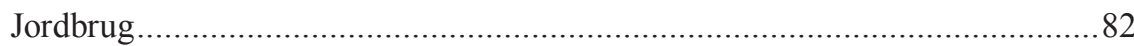

3-6510-1 Projektmidler - Jordbrug $\quad 82$

3-6520-2 Kontaktorgan for jordbrugsforskning (NKJ) 83

3-6585-3 Nordisk Genressource Center (NordGen) 84

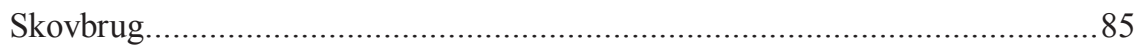


3-6310-1 Projektmidler - Skovbrug 85

3-6581-2 Samnordisk skogsforskning (SNS) 86

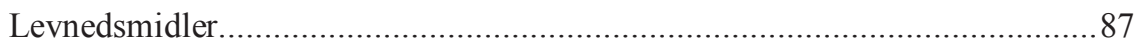

3-6810-1 Projektmidler - levnedsmidler $\quad 87$

3-6820-1 Forskning - levnedsmidler $\quad 89$

3-6830-1 Nordisk handlingsplan for bedre helse og livskvalitet $\quad 89$

$\begin{array}{ll}\text { Jämställdhet } & 90\end{array}$

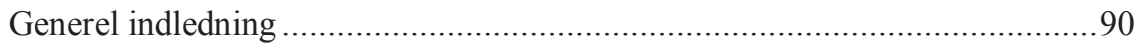

1-4410-1 Projektmedel - Jämställdhet 95

1-4480-2 Nordisk information för kunskap om kön (NIKK) 96

$\begin{array}{ll}\text { Uddannelse og forskning } & 97\end{array}$

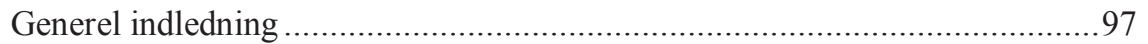

Generelle forsknings- og uddannelsesindsatser........................................... 105

2-2505-1 Dispositionsmidler - Uddannelse og forskning 105

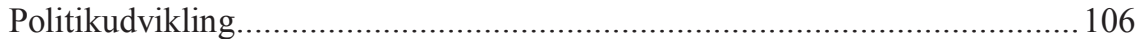

2-2510-1 Rådgivningsgruppen for nordisk skolesamarbejde (NSS) 106

2-2520-1 Rådgivningsgruppen for nordisk samarbejde om voksnes læring (SVL) 106

2-2530-1 Rådgivningsgruppen for nordisk samarbejde indenfor højre uddannelse (HÖGUT) 106

2-2560-1 Ad hoc arbejdsgrupper på prioriterede områder 106

2-2544-1 Det nordiske sprogsamarbejde 107

2-2553-1 Politikudvikling, Videnssamfund og IT-infrastruktur 109

2-3127-2 Politikudvikling voksnes læring 110

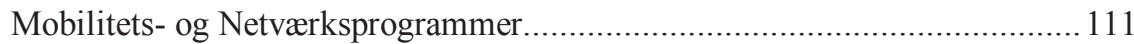

2-2513-2 Nordplus 111

2-2534-4 Bidrag till Nordiskt Sommaruniversitet 113

2-2545-2 Samarbejdsnævn et for Nordenundervisning i udlandet $\quad 114$

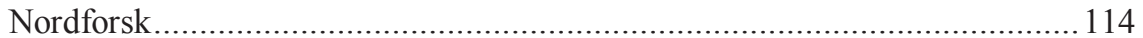

2-3100-3 Nordforsk 114

2-3140-2 Nordisk komité for Bioetik 119

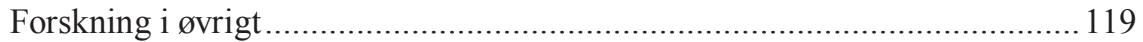

2-3180-2 Nordisk Institut for Teoretisk Fysik (Nordita) 119

2-3181-2 Nordisk Institutt for sjørett (NIfS) 121

2-3182-2 Nordisk Institut for Asienstudier (NIAS) 123

2-3184-2 Nordisk vulkanologisk institut (NORDVULK) 125

2-3185-2 Nordisk Samisk Institut (NSI) 126 


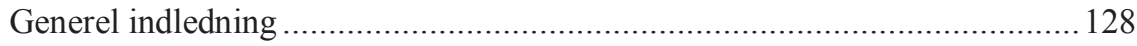

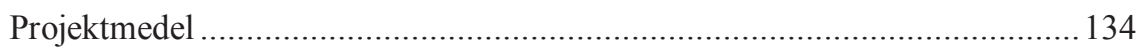

4-4310-1 Projektmidler - Social- och hälsvårdspolitik 134

4-4320-1 Rådet för nordiskt samarbete om funktionshinder 135

4-4340-1 Nomesko och Nososko 135

4-4382-1 NIOM A/S - Nordisk Institutt for Odontologiske Materialer 136

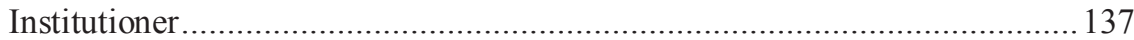

4-4380-3 Nordens Välfärdscenter (NVC) 137

4-4381-3 Nordiska högskolan för folkhälsovetenskap (NHV)* 139

Närings-, Energi och Regionalpolitik $\quad 141$

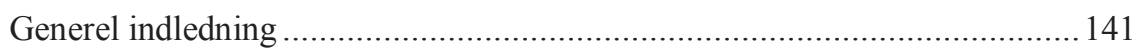

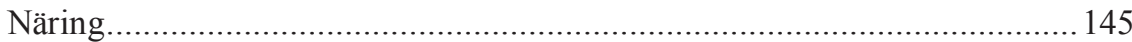

4-5140-1 Projektmedel - Näring 145

4-5180-3 Nordisk Innovation 145

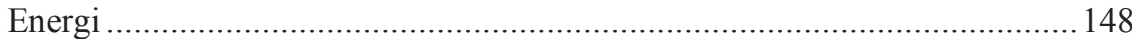

4-5141-1 Projektmedel - Energi 148

4-5142-2 Arbetsgrupper - Energi 149

4-3220-3 - Nordisk Energiforskning (NEF) 149

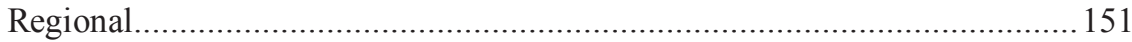

4-5143-1 Implementering av samarbetsprogram, demografi, arbetsgrupper och projektmedel - Regional 151

4-5145-2 Arbetsgrupper under Regional 153

4-5151-4 NORA 154

4-5160-2 Gränsregionalt samarbete $\quad 155$

4-6180-3 Nordregio 155

$\begin{array}{ll}\text { Miljö } & 158\end{array}$

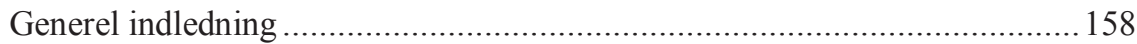

3-3310-1 Dispositionsmedel - Miljö 161

3-3311-2 Miljösektorns arbetsgrupper 161

3-3320-2 NEFCOS Miljöutvecklingsfond 162

3-6720-4 SVANEN - Nordisk Miljömärkning 165

$\begin{array}{ll}\text { Arbejdslivspolitik } & 167\end{array}$

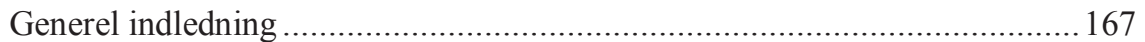

2-4110-1 Projektmedel i övrigt - Arbetsliv 170

2-4111-2 Arbejdsliv faste udvalg $\quad 171$

2-4120-2 Nordjobb 173 
2-4130-1 Kommunikation om arbetsliv 173

2-4180-3 Institut for videreuddannelse inden for arbejdsmiljø (NIVA) 174

$\begin{array}{ll}\text { Ekonomi- og Finanspolitik } & 177\end{array}$

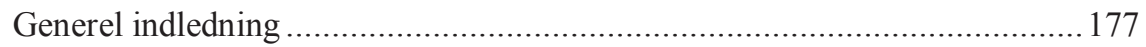

4-5210-1 Projektmedel - Ekonomi- och Finanspolitik 180

$\begin{array}{ll}\text { Lagstiftning } & 183\end{array}$

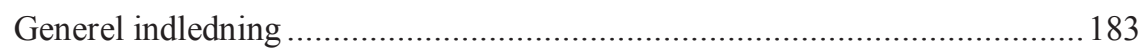

1-7110-1 Projektmedel - Lagstiftning 185

$\begin{array}{ll}\text { Internationalt samarbejde } & 187\end{array}$

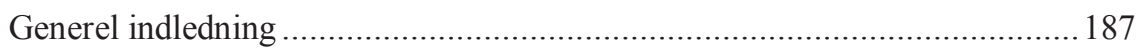

6-0820-2 Kunskapsuppbyggning och nätverk 190

6-0980-1 Partnerskap och gränsregionalt samarbete 192

6-0960-1 NGO-verksamhet i Östersjöregionen 194

6-5280-2 Nopef 195

6-0970-3 Ministerrådets kontor i Nordväst Ryssland 197

6-0810-3 Ministerrådets kontor i Estland, Lettland och Litauen 199

6-0910-1 Politiska initiativ 200

6-0870-1 Arktiskt samarbetsprogram 201

6-0950-2 EHU/Vitryssland 203

6-0990-1 Samarbetet med Nordens grannar i Väst 204

Samarbejdsministrene $\quad 205$

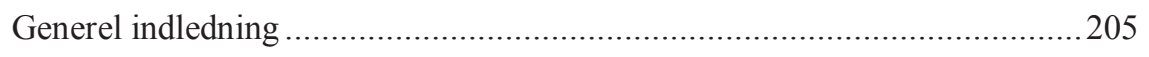

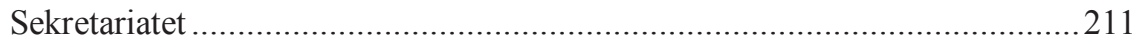

5-0180-3 Ministerrådets sekretariat (NMRS) 211

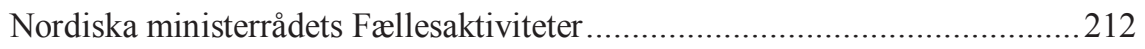

5-0410-4 Föreningarna Nordens Förbund 212

5-0425-4 Bidrag till Västnorden 213

5-0435-1 Generalsekreterarens disponeringsreserv 213

5-0445-1 Formandsskabspuljen 213

5-0460-1 Hållbart Norden 214

5-1011-1 Informationsaktiviteter 215

5-1012-1 Norden i Fokus 217

5-1021-1 Internationella aktiviteter 218

5-1030-2 Hallo Norden 218

5-1035-1 Gränshinder 219

5-1036-1 Grænsehindringsråd 219

5-1050-2 Tjänstemannautbyte 221

5-0500-2 Pulje till Nordiska ministerrådets stöd till Island 222 
$\begin{array}{ll}\text { Globalisering } & 224\end{array}$

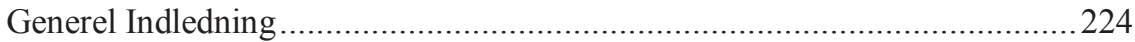

5-2020-1 Globaliseringsforum 224

5-2025-2 Nordisk Topforskning 224

5-2030-2 Innovationsrepresentationer 224

5-2042-1 Energi och transport inkl. uppföljning på gemensamt nordiskt

Energi Expo 225

5-2055-1 Gränshinderforum 225

5-2060-2 Utvecklingen av det nordiska forsknings- och innovations-området

(NORIA) 225

5-2062-1 e-Science 225

5-2065-1 Främjande av högre utbildning i Norden 226

5-2070-1 En god uppläring av ungdomar och vuxna 226

5-2075-2 Belysning av konsekvenserna av klimatförändringarna på naturresurser i Norden 226

5-2076-2 Harmonisering av el-marknaden i Norden 226

5-2080-2 Kultur och kreativitet 227

5.2085-2 Hälsa och välfärd 227

Nordisk Ministerråds budget for virksomhedsåret 2014

Forhandlinger med Nordisk Råd og det opnåede kompromisforslag...............229

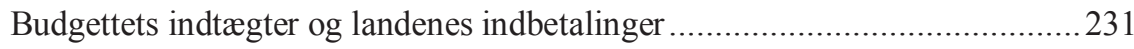

Økonomiske og politiske frihedsgrader i Nordisk Ministerråds budget...........233

Historisk udvikling i Nordisk Ministerråds budget og likviditet 236

Udviklingen i udisponerede midler 2010 - 2012 ........................................2236

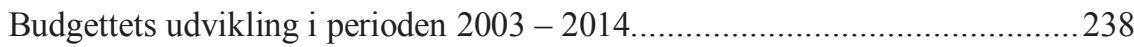

Budgettets fordeling på budgetpostkategorier .............................................240

Bilag 1 - Budgettet konverteret til EURO 242

Bilag 2 - Status 31. 122012 på budgetpostniveau 250

Bilag 3 - Forklaringer til Budgetstruktur og Budgetpost-kategorier 256

Bilag 4 - Økonomiske delegeringsregler i Nordisk Ministerråd $\quad 258$

Bilag 5 - Förteckning över förkortningar 260 
Nordisk Ministerråd godkender, med forbehold for de nationale parlamenters godkendelse, vedlagte budget for år 2014 på totalt 937,390 MDKK (2013 -prisniveau).

Ministerrådet finansieres for langt størstedelens vedkommende gennem bidrag fra de nordiske landene efter en fordelingsnøgle, som årlig fastsættes af Ministerrådet som de respektive landes andel af den samlede nordiske bruttonationalindkomst. Derudover har Ministerrådet indtægter fra øvrige aktiviteter, der udgør ca. 1,4\% af budgettet.

Fordelingsnøglen for landenes indbetalinger for år 2014 er:

$\begin{array}{lr}\text { Danmark } & 21,0 \% \\ \text { Finland } & 16,3 \% \\ \text { Island } & 0,7 \% \\ \text { Norge } & 30,6 \% \\ \text { Sverige } & 31,4 \%\end{array}$

Aftalen om overenskomst om tilgang til højere uddannelse påvirker landenes indbetalinger til det nordiske budget ved at selve betalingsordningen håndteres via Ministerrådets budget. Betalingsordningen gælder Danmark, Finland, Norge og Sverige. Island, Grønland, Færøerne og Åland deltager ikke i betalingsordningen. Det er taget hensyn til de berørte landes gensidige betalinger jf. overenskomsten i de involverede landes endelige bidrag til Ministerrådets budget.

Ved fastsættelsen af budgettet anvender Ministerrådet det aritmetiske gennemsnit af Danmarks Nationalbanks månedsgennemsnitskurser i perioden 1. oktober 2012-30. september $2013^{1}$ :

$$
\begin{aligned}
& 100 \mathrm{EUR}=746 \mathrm{DKK} \\
& 100 \mathrm{ISK}=4,6 \mathrm{DKK} \\
& 100 \mathrm{NOK}=98 \mathrm{DKK} \\
& 100 \mathrm{SEK}=87 \mathrm{DKK}
\end{aligned}
$$

\footnotetext{
${ }^{1}$ Da Danmarks Nationalbank ikke længere noterer ISK, er kursen på ISK beregnet ud fra det aritmetiske gennemsnit af Den islandske Nationalbanks månedsgennemsnitskurser i perioden 1. oktober 2012 30. september 2013.
} 
Til prisopregning af institutionernes tilskud og projektmidler benyttes følgende opregningsfaktorer:

1. Omregningsfaktorerne for bidrag til institutionerne for år 2014 er:

$\begin{array}{ll}\text { Danmark } & 1,5 \% \\ \text { Finland } & 2,1 \% \\ \text { Island } & 3,0 \% \\ \text { Norge } & 2,25 \% \\ \text { Sverige } & 0,87 \%\end{array}$

2. Omregningsfaktoren for projektmidler er 1,6 \% for år 2014.

Landenes indbetalinger til budgettet for år 2013 sker i henhold til Nordisk Ministerråds Økonomireglement $§ 7$.

Ministerrådet har bemyndiget generalsekretæren til

- $\quad$ at tage beslutning om institutionernes budget, når det gælder omregning til og udbetaling $i$ anden valuta

- $\quad$ at tage beslutning om omdisponeringer på op til og med 300.000 DKK mellem budgetposter indenfor totalrammen.

Samarbejdsministrene fastsætter rammen for kultur/uddannelse/forskning til 399.002 TDKK (2013-prisniveau). De ansvarlige ministerråd skal inden for denne ramme fastsætte detailfordelingen for deres respektive områder i henhold til Aftalen om kulturelt samarbejde artikel 15. 


\section{Forord}

Den samlede økonomiske ramme for budsjettet i 2014 er vel 955 MDKK. Med nærmere $1 \mathrm{mrd}$. kroner til rådighet legger budsjettet opp til en fortsatt høy prioritering av det nordiske samarbeidet med den struktur og de aktiviteter dette gir rom for.

Budsjettet inneholder en videreføring av satsningene i prioriteringsbudsjettet som ble introdusert i 2013. Prioriteringsbudsjettet skal være med å fornye og utvikle det nordiske samarbeidet. En del av prioriteringsbudsjettet er forbeholdt til å finansiere initiativer som formannskapslandene ønsker å iverksette. Hvert land har tre år til rådighet for sine satsninger. I 2014 videreføres noen av det svenske formannskapets satsninger fra 2013. Det kommer også tre nye innsatsområder fra det islandske formannskapet $\mathrm{i}$ 2014 - Bioøkonomi, velferdsvakten og den nordiske spillelisten.

I tillegg til de satsninger som ligger i prioriteringsbudsjettet gir det samlede budsjettet rom for en fortsatt prioritering av grensehinderarbeidet der det $\mathrm{i}$ 2014 trer i kraft en ny strategi- og handlingsplan samt at det etableres et Grensehinderråd. Det legges opp til flere politiske initiativ med tilhørende aktiviteter i samtlige sektorministerråd.

Budsjettet innebærer en $5 \%$ lavere ramme i forhold til budsjettet for 2013.

Det nordiske samarbeidet skal moderniseres, og det forberedes derfor flere tiltak som har til hensikt å utvikle, målrette og effektivisere samarbeidet.

Ved flere anledninger har budsjettet vært drøftet med Nordisk råd. Dialogen med Nordisk råd har resultert i et budsjettkompromiss som samlet sett gir et sterkt nordisk budsjett med klare politiske prioriteringer.

København 27. november 2013.

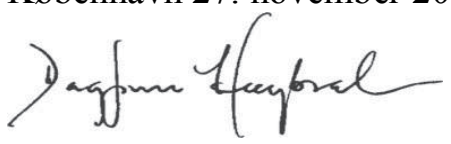

Dagfinn Høybråten

Generalsekretær 
Den totale udgiftsramme for Nordisk Ministerråds budget for virksomhedsåret 2014

\section{Den totale udgiftsramme for Nordisk Ministerråds budget for virksomhedsåret 2014}

Den totale udgiftsramme for 2014 for Nordisk Ministerråd er i alt $\mathbf{9 5 5 . 2 1 5}$ TDKK, som er $5 \%$ nedskæring fra budget 2013 (i 2013 priser). Dette svarer til 49 MDKK besparelse.

Rammen kan specificeres således:

\begin{tabular}{rr}
\hline Sammensæetningen af den samlede ramme & TDKK \\
\hline Budget 2013 & $\mathbf{9 8 6 . 7 2 6}$ \\
Besparelse 5\% & -49.336 \\
Vedtaget budget 2014 i 2013 priser & 937.390 \\
Prisomregningseffekt til 2014 prisniveau & 16.003 \\
Valutaomregningseffekt & 1.822 \\
\hline Total i 2014 priser & $\mathbf{9 5 5 . 2 1 5}$ \\
\hline
\end{tabular}

Til budgetrammen for 2014 (i 2013 priser) lægges effekten af pris- og valutaomregningen med de prisomregningsfaktorer og valutakurser, som vises på side $11 \mathrm{og}$ det giver den totale udgiftsramme for Nordisk Ministerråd for 2014.

Effekten af prisomregningen i budget 2014 betyder en inflationskompensation på 16.003 TDKK, svarende til en gennemsnitlig prisopregningsprocent på $1,7 \%$. Effekten af valutaomregningen til DKK af institutionernes bevillinger i national valuta betyder en stigning i budgettet på 1.822 TDKK. Det skal dog understreges, at det ikke har nogen realvirkning på budgettets størrelse (og landenes indbetalinger) eller på størrelsen af institutionernes bevillinger. Valutakursernes benyttes alene til at omregne institutioners bevillinger, som udbetales i domicillandets valuta, til DKK.

På næste side ses fordeling af udgiftsrammen på budgetsektorer for 2014 . 
SAMMENSTILLING AF BUDGET 2014 OG 2013 (løbende priser, TDKK)

\begin{tabular}{|c|c|c|c|c|c|c|}
\hline & \multirow{2}{*}{$\begin{array}{c}\text { Budget } \\
2014 \\
\end{array}$} & \multirow[t]{2}{*}{ Andel } & \multirow{2}{*}{$\begin{array}{c}\text { Budget } \\
2013 \\
\end{array}$} & \multirow[t]{2}{*}{ Andel } & \multicolumn{2}{|c|}{ Difference } \\
\hline & & & & & $+/-$ & $\%$ \\
\hline Prioriteringsbudgettet & 74.768 & $7,8 \%$ & 81.441 & $8,3 \%$ & -6.673 & $-8,2 \%$ \\
\hline Formandskapspuljen & 30.480 & $3,2 \%$ & 20.360 & $2,1 \%$ & 10.120 & $49,7 \%$ \\
\hline Prioriteringspuljen & 44.288 & $4,6 \%$ & 61.081 & $6,4 \%$ & -16.793 & $-27,5 \%$ \\
\hline $\begin{array}{l}\text { MR-Kultur, MR-FJLS, MR- } \\
\text { Ligestilling }\end{array}$ & 217.891 & $22,8 \%$ & 224.051 & $22,7 \%$ & -6.160 & $-2,7 \%$ \\
\hline Kultur & 167.879 & $17,6 \%$ & 173.335 & $17,6 \%$ & -5.456 & $-3,1 \%$ \\
\hline $\begin{array}{l}\text { Fiskeri, Jord- och skovbrug og } \\
\text { levnedsmidler }\end{array}$ & 41.093 & $4,3 \%$ & 41.598 & $4,4 \%$ & -505 & $-1,2 \%$ \\
\hline Ligestilling & 8.919 & $0,9 \%$ & 9.118 & $0,9 \%$ & -199 & $-2,2 \%$ \\
\hline $\begin{array}{l}\text { MR-Uddannelse og forskning, } \\
\text { MR-S }\end{array}$ & 278.677 & $29,2 \%$ & 283.930 & $28,8 \%$ & -5.253 & $-1,9 \%$ \\
\hline Uddannelse og forskning & 238.384 & $25,0 \%$ & 243.071 & $24,6 \%$ & -4.687 & $-1,9 \%$ \\
\hline Socialpolitik & 40.293 & $4,2 \%$ & 40.859 & $4,1 \%$ & -566 & $-1,4 \%$ \\
\hline $\begin{array}{l}\text { MR-NER, MR-Miljø, MR-A, MR- } \\
\text { Finans }\end{array}$ & 185.409 & $19,4 \%$ & 188.930 & $19,1 \%$ & -3.521 & $-1,9 \%$ \\
\hline Näring, energi og regional & 125.500 & $13,1 \%$ & 127.694 & $12,9 \%$ & -2.194 & $-1,7 \%$ \\
\hline Miljø & 44.392 & $4,6 \%$ & 45.389 & $4,6 \%$ & -997 & $-2,2 \%$ \\
\hline $\begin{array}{l}\text { Arbejds- } \\
\text { liv }\end{array}$ & 13.698 & $1,4 \%$ & 13.992 & $1,4 \%$ & -294 & $-2,1 \%$ \\
\hline Finanspolitik & 1.819 & $0,2 \%$ & 1.855 & $0,2 \%$ & -36 & $-1,9 \%$ \\
\hline MR-Lag & 1.390 & $0,1 \%$ & 1.418 & $0,1 \%$ & -28 & $-2,0 \%$ \\
\hline Lag & 1.390 & $0,1 \%$ & 1.418 & $0,1 \%$ & -28 & $-2,0 \%$ \\
\hline Samarbejdsministrene & 197.080 & $20,6 \%$ & 206.956 & $21,0 \%$ & -9.876 & $-4,8 \%$ \\
\hline Internationalt samarbejde & 89.718 & $9,4 \%$ & 95.592 & $10,0 \%$ & -5.874 & $-6,1 \%$ \\
\hline Ministerrådets sekretariat (NMRS) & 78.204 & $8,2 \%$ & 80.804 & $8,2 \%$ & -2.600 & $-3,2 \%$ \\
\hline $\begin{array}{l}\text { Nordisk Ministerråds fællesaktivite- } \\
\text { ter }\end{array}$ & 29.158 & $3,1 \%$ & 30.560 & $3,1 \%$ & -1.402 & $-4,6 \%$ \\
\hline TOTALT & 955.215 & $100 \%$ & 986.726 & $100 \%$ & -31.511 & $-3,2 \%$ \\
\hline
\end{tabular}




\section{Læsevejledning}

Budget 2014 består af 3 hovedelementer. En indledende generel beskrivelse af ministerrådets planer for 2014, som sammenfatter de vigtigste prioriteringer og indsatser i de forskellige fagministerråd og for samarbejdsministrene. Næste del, som er den mest omfattende, indeholder oversigt over samtlige budgetposter, inddelt efter sektor. Hvert sektorområde indledes med en generel beskrivelse af sektoren, dens vigtigste styringsdokumenter og opnåede resultater i senest afsluttede regnskabsår - 2012. Endvidere beskrives sektorens udmøntning af besparelserne i 2014. Hver enkelt budgetpost indeholder oplysninger om budgetårets budget, de to seneste års budgetter, hvor stor en del af budgettet der blev disponeret sidste år samt hvem der bemyndiges til at træffe beslutning om anvendelsen af bevillingen. Herudover er der til hver budgetpost en beskrivelse af formålet med bevillingen samt hvilke prioriteringer der er for budgetåret. Endelig er der til budgetposter, hvor det er relevant, oplysninger om udgifter til ledelse og administration, kontraktstatus samt hvem der udfører sekretariatsfunktionen, hvis det ikke er en institution eller varetages af ministerrådets sekretariat.

Budgetposterne er inddelt i 4 forskellige kategorier: projektmidler, programlignende aktiviteter, institutioner og organisationsbidrag. For uddybende forklaring se Bilag 3.

Sidste del af budgetforslaget består at nogle tværgående oversigter, herunder oplysninger om finansieringen fordelt på lande, betalingsordningen for højere uddannelse og en opgørelse over de økonomiske frihedsgrader. Hertil kommer historiske data om udviklingen i det samlede budget, likviditeten, fordelingen af udgifter på budgetpostkategorier, de udisponerede midler samt nogle bilag med bl.a. budgettet i euro, økonomiske delegeringsregler og en fortegnelse over brugte forkortelser. 


\section{Nordisk Ministerråds planer for virksomhedsåret 2014}

\section{Hovedlinjer i budget 2014}

Nordisk Ministerråd er forum for det formelle samarbejde mellem de nordiske regeringer. Ministerrådets arbejde er overordnet reguleret af Helsingfors-aftalen, der senest er blevet ændret i 1995.

Det er de nordiske samarbejdsministre(MR-SAM), der har det overordnede ansvar for koordinering af Ministerrådets arbejde. Herudover udføres samarbejdet i 10 fagministerråd.

Formandskabet i Nordisk Ministerråd skifter hvert år og roterer mellem landene. Island afløser i 2014 Sverige som formandskabsland for Nordisk Ministerråd.

Samarbejdsministrene har besluttet, at der skal gennemføres en besparelse på $5 \%$ på det nordiske budget i 2014. De har endvidere besluttet, at besparelsen skal gennemføres ved at reducere alle sektorrammer med 3,5\%, reducere prioriteringsbudgettet med yderligere $5 \mathrm{MDKK}$, kultursamarbejdet med yderligere 1,4 MDKK, internationalt samarbejde med yderligere 4,4 MDKK og endelig skal der findes 4 MDKK ved administrative besparelser i det nordiske samarbejde.

På trods af sparekravet på 5 \% fortsættes de prioriterede satsninger fra 2013 på "Grøn Vækst" og "Holdbar Velfærd", ligesom de nye svensk initierede formandskabssatsninger fra 2013 videreføres i 2014 og 15. Hertil kommer så nye satsninger foreslået fra det kommende islandske formandskab, som i 2014 vil være rettet mod "Bio-økonomi", "Velfærdsvagten" og "Musikeksport" under Nomex.

Budgetforslaget er udarbejdet på grundlag af fagministerrådenes bidrag og følger sektorernes forslag til prioriteringer og nedskæringer.

Samarbejdsministrenes forslag til budget vedtages i september på grundlag af generalsekretærens forslag og en national høring i de nordiske lande.

Det endelige budget for 2014 vedtages i oktober af samarbejdsministrene efter drøftelser med Nordisk Råd. 


\section{Hovedlinjer i Ministerrådenes politiske prioriteringer}

\section{Prioriteringsbudgettet:}

Samarbejdsministrene besluttede i 2012 at oprette et prioriteringsbudget indenfor Nordisk Ministerråds budgetramme fra 2013.

Prioriteringsbudgettet skal anvendes til at igangsætte nye større og overgripende tematiserde satsninger. I 2014 vil vægten ligge på prioriterede indsatser hos det svenske og islandske formandsskab, samt områderne grøn vækst, helse og velfærd samt videreførelse af visse globaliseringsinitiativer.

\section{Tema: Ordförandeskapsandelen}

I den del av prioriteringsbudgeten som öronmärkts för initiativ som initierats av det svenska ordförandeskapet 2013 kommer tre av initiativen att vidareföras 2014: 1) expertnätverket med syfte att föra samman intressenter från den nordiska gruv- och mineralsektorn (NordMin), 2) projektet för att förbättra de nordiska ländernas emissionsinventeringar av kortlivade klimatpåverkande luftföroreningar, s.k. SLCP och 3) projektet som syftar till att genom arbete ge anpassad och praktisk, värderad och dokumenterad utbildning som leder till arbete.

Under det isländska ordförandeskapet 2014 kommer det att igångsättas tre initiativ inom ramen för prioriteringsbudgeten: 1) en nordisk bio-ekonomi satsning som omfattar ett samarbetsprojekt mellan de ministerråd som är ansvariga för näringsliv, innovation, miljö och naturresurser, 2) ett initiativ om den nordiska välfärdsvakten som omfattar en granskning av de lösningar och åtgärder på välfärdsområdet som vidtagits för att möta de hot och utmaningar som de nordiska välfärdssystemen står inför, och 3) en initiativ om den nordiska spellistan som gäller export av kreativa näringar, speciellt nordisk musikexport.

\section{Tema: Gron vækst}

Visionen "Norden - ledande i grön tillväxt" understryker, att de nordiska länderna tillsammans utnyttjar sin position när det gäller energieffektivisering, utveckling av hållbar energi, miljömedvetenhet, innovations- och forskningssatsningar och höga internationella målsättningar på miljö/klimatområdet. Genom att Norden agerar tillsammans kan satsningar inom grön tillväxt uppnå en större massa, skapa en större marknadsstorlek 
samt uppnå ett större politiskt genomslag i pågående internationella processer.

På det nordiska statsministermötet i november 2011, gav statsministrana i uppdrag till olika fackministrar att vidareutveckla de åtta konkreta förslagen som presenterades i rapporten "Norden-ledande i grön tillväxt" från arbetsgruppen för grön tillväxt.

Generalsekreteraren för Nordiska Ministerrådet ska säkra en effektiv och tät koordinering av arbetet som statsministrarna har beslutat skall utföras i de relevanta nordiska fackministerråden där arbetet är en högt prioriterad uppgift 2014.

\section{Tema: Hållbar Nordisk Välfärd}

Hållbar nordisk välfärd är Nordiska ministerrådets program för nya välfärdslösningar. De nordiska länderna står alla inför stora utmaningar i förhållande till att säkra välfärdssystemens utveckling och hållbarhet. Utmaningarna är kopplade till en rad omställningar i samhället kopplade till exempelvis globalisering, demografiska förändringar, attitydförändringar, nya teknologiska utvecklingar och så vidare.

Programmet Hållbar nordisk välfärd, som gäller för perioden 2013-2015, initierar både samarbete i konkreta insatser och etablerar nordiska plattformer för dialog och kunskapsutbyte.

Inom ramen för programmet realiseras de nordiska statsministrarnas uppmaning från 10 juni 2012 till de nordiska hälsoministrarna om att utarbeta konkreta förslag till en vidareutveckling av det nordiska hälsosamarbetet, däribland utprövning av nya läkemedel och behandlingar, samarbete om högspecialiserade funktioner samt forskning om hälsa och välfärd. Programmet rymmer utöver en utveckling och konkretisering av det nordiska hälsosamarbetet också konkreta insatser inom utbildnings- och arbetsmarknadsområdet.

Hållbar nordisk välfärd realiseras genom insatser och aktiviteter inom följande tre insatsområden:

- Utbildning och arbete för välfärd

- Forskning för välfärd

- Infrastruktur för välfärd 
MR-U och MR-S är gemensamt projektägare och därmed huvudansvariga för Hållbar nordisk välfärd.

\section{Tema: Nordisk Ministerråds globaliseringsinitiativ}

Globalisering identifierades som ett nytt prioriterat område för det nordiska samarbetet i samband med statsministrarnas möte i Punkaharju, Finland 2007. Sedan 2008 har totalt 22 globaliseringsinitiativ startats inom NMR. Grundtanken har varit att globaliseringssatsningen som helhet avslutas vid utgången av år 2012, men vissa av de enskilda initiativen har ett motiverat krav för en fortsatt finansiering även under 2014.

Samarbejdsministrene (MR-SAM) prioriterer herudover fortsat særligt det internationale samarbejde, særligt samarbejde med nabolandene i Østersøregionen, arbejdet med at forebygge og nedbryde grænsehindringer, samt arbejdet med bæredygtig udvikling.

Internationalt samarbejde. Nordisk Ministerråds internationale samarbejde har til formål at styrke den samlede region med særligt fokus på Østersøregionen. Indsatsen i og for Arktis forsættes gennem det arktiske samarbejdsprogram og samarbejdet med naboerne i Vest fortsættes i tråd med retningslinjerne. MR-SAM vil i dialog med Nordisk Råd udvikle det fremtidige internationale samarbejdes form og indhold.

Målsætningen for Ministerrådets samarbejde med nabolandene i Østersøregionen og Barentsregionen er at skabe en sammenhængende, velstående og stabil region og gennem samarbejde på områder af fælles interesse. Nordisk Ministerråd har i gennem mange år samarbejdet med Estland, Letland og Litauen og Nordvestrusland, hvor ministerrådets fire kontorer i regionen har en central rolle. I de senere år er det regionale samarbejde blevet intensiveret, dels gennem EU's Østersøstrategi, dels gennem fælles aktiviteter og programmer med de baltiske lande henholdsvis Rusland. Ministerrådet samarbejder også aktivt med de øvrige regionale råd og organisationer i regionen samt med EU, og bidrager til partnerskaberne under Den Nordlige Dimension. Endvidere er der et begyndende samarbejde med Polen og Tyskland på udvalgte områder af fælles interesse.

Ministerrådets Hvideruslandsaktiviteter omfatter støtte til eksiluniversitetet European Humanities University i Vilnius, Litauen, gennem EHU Trust 
Fund som administreres af Nordisk Ministerråd og samler støtte fra 18 donorer i Europa og USA.

Demokratiudvikling og styrkelse af civilsamfundet støttes også gennem Ministerrådets NGO-program, samt projektet Civil Society Sta-bility for Belarus som finansieres af EU og administreres af Nordisk Ministerråd. Stipendieprogrammet Open Europe Scholarship Scheme (OESS) administreres ligeledes af Ministerrådet, samt finansieres af EU. Programmet har til formål at give hviderussiske studerende en mulighed for at gennemføre højere uddannelse på et europæisk universitet.

I forbindelse med Hvideruslandsaktiviteterne har Ministerrådet et tæt samarbejde med EU.

Nordisk Ministerråds arbejde i og for Arktis fortsættes med det arktiske samarbejdsprogram, der har fokus på det overordnede emne, bæredygtig udvikling, med indsatsområderne klima og miljø, befolkning, sundhed, uddannelse og kompetenceudvikling. Aktiviteterne i Ministerrådets arktiske samarbejdsprogram gøres i henhold til prioriteringerne i de nordiske landes strategier, Arktisk Råd, Ministerrådets egne strategier, samt andre relevante fora.

Med naboerne i Vest ønsker Ministerrådet særligt at øge samarbejdet på områderne forskning, innovation og klima, samt at skabe synergi med det arktiske samarbejdsprogram.

Bæredygtig udvikling. De nordiska samarbetsministrarna har förnyat sitt engagemang för arbetet med hållbar utveckling genom att ta fram en ny nordisk strategi för hållbar utveckling. Strategin, Ett gott liv i ett hållbart Norden, är den överordnade och tvärsektoriella ramen för Nordiska ministerrådets arbete. Allt arbete som görs inom ministerrådet ska ha ett integrerat hållbarhetsperspektiv.

Nordiska ministerrådet ska bidra till att de nordiska länderna successivt fortsätter att förbättra välfärden och livskvaliteten för nuvarande och kommande generationer genom att skydda och tillvarata jordens förmåga att uppehålla liv i hela dess mångfald.

Strategin ger långsiktiga riktlinjer fram till 2025 inom följande fokusområden: 


$\begin{array}{ll}\text { - } & \text { den nordiska välfärdsmodellen, } \\ \text { - } & \text { livskraftiga ekosystem, } \\ \text { - } & \text { ett förändrat klimat, } \\ \text { - } & \text { ett hållbart nyttjande av jordens resurser, samt } \\ & \text { utbildning, forskning och innovation. }\end{array}$

Nordiska ministerrådets facksektorer kompletterar strategin med konkreta insatser och utvecklingen i Norden följs upp med hjälp av indikatorer.

Arbetet mot gränshinder för såväl privatpersoner som företag får tydligare former och innehåll. Mandatet för det nuvarande Gränshindringsforum utlöper i 2013. Sedan maj 2012 har en nordisk arbetsgrupp tillsatts för att utveckla en flerårig handlingsplan för gränshinderarbetet, under arbetet har även en översyn över såväl befintliga som tänkbara gränshindersaktörer gjorts. Handlingsplanen kommer att presenteras under Nordiska rådets session i Oslo i oktober 2013. Målsättningen är att en möjlig ny organisering, med sektorförankrade mål ska tas i bruk 1 januari 2014. En del i arbetet kommer också att vara att följa upp på de lösningsförslag som lades fram i rapporten från ämbetsmannakommittéerna på social- respektive arbetsmarknadssektorerna. Dessutom kommer man under året att fokusera på gränshinder rörande yrkeskvalifikationer, skattefrågor för små och medelstora företag som vill utföra uppdrag över de nordiska gränserna samt nordiska kulturarbetare vid arbete i olika nordiska länder.

Ministerrådet for Arbejdsliv (MR-A) har ansvar for Nordisk Ministerråds samarbejde inden for områderne beskæftigelse og arbejdsmarked samt arbejdsmiljø og arbejdsret. I MR-A's samarbejdsprogram 2013-2016 fremhæves globaliseringen og den demografiske udvikling som de langsigtede udfordringer samarbejdet i særlig grad vil blive rettet mod. Samtidig vil samarbejdet efter behov prioritere også mere konjunkturelt betingede udfordringer, som opstår i perioden.

Det overordnede formål med samarbejdet er at bidrage til at sikre et velfungerende nordisk arbejdsmarked og et godt arbejdsliv i et konkurrencedygtigt Norden.

Målene omfatter bl.a. at tilvejebringe en tilstrækkelig, kompetent og omstillingsparat arbejdsstyrke, at bekæmpe ledigheden blandt udsatte grupper og langtidsledighed, at styrke et godt fysisk og psykisk arbejdsmiljø på arbejdspladserne, at styrke balancen mellem lønmodtagerbeskyttelse og fleksibilitet, at fremme ligestilling og ligebehandling på arbejdsmarkedet, 
at styrke det nordiske samarbejde i forhold til international regulering og at bekæmpe grænsehindringer.

Ministerrådet for Økonomi- og Finanspolitik (MR-FINANS) bidrar via samarbetet på det ekonomiska och finansiella området till att skapa förutsättningar för att de grundläggande ekonomisk-politiska målen om en stabil och sund ekonomisk utveckling med hög sysselsättning samt god och uthållig tillväxt skall kunna uppnås.

EU-frågor är av hög prioritet inom det nordiska ekonomiska och finansiella samarbetet. Sektorn har dessutom en ordning för systematiskt samråd och samarbete om EU-frågor på det ekonomiska och finansiella området. Flera EU-relaterade frågor som kommer att behandlas inom ramen för Ekofinrådets verksamhet kan förutses att bli aktuella. Andra områden som väntas utgöra viktiga delar av arbetet inom sektorn under 2014 är uppföljningen av arbetet med att avlägsna gränshinder mellan de nordiska länderna, systematiskt samråd och samarbete om skattefrågor och skatteflykt samt fortsatt samarbete för att verka för att den ekonomiska dimensionen inkorporeras på ett tydligare sätt i den nordiska strategin om hållbar utveckling. En annan prioritering under året kommer vara uppföljning av uppdraget från de nordiska statsministrarna om grön tillväxt, som inriktas mot hur man kan stödja finansieringen av växande gröna företag och investeringar.

Ministerrådet for Fiskeri og havbrug, Jordbrug, Levnedsmidler og Skovbrug (MR-FJLS) arbejder for at styrke en bæredygtig udvikling inden for de fire sektorer fiskeri og havbrug, jordbrug, levnedsmidler og skovbrug. Målet er, at styrke rammerne for en økonomisk vækst og velfærdsudvikling, som på samme tid bidrager til at sikre bedre miljømæssige, sundhedsmæssige, sociale og regionale udviklinger.

Samarbejdet tilrettelægges derfor gennem fokus på tre overordnede udfordringer, som alle har karakter af at være grænseoverskridende, og derfor samtidig er en del af den globale dagsorden, som Norden og sektorerne under MR-FJLS står over for:

- Konkurrencedygtig produktion

- Bæredygtig naturressourceforvaltning

- Øget velfærd 
Rammeprogrammet suppleres af det islandske formandskabsprogram for 2014. Det islandske formandskabsprogram for 2014 har bioøkonomi som hovedtema. Programmet omfatter tre ministerråd, og inkluderer otte embedsmandskomiteer, herunder alle komiteerne under FJLS-området.

Ministerrådet for Jämställdhet (MR-JÄM) arbetar inom ramen för det fyra-åriga samarbetsprogrammet för jämställdhet, Jämställdhet skapar ett hållbart samhälle 2011-2014. Samarbetsprogrammet fokuserar på tre prioriterade teman nämligen samarbete i Norden, samarbete med de tre baltiska länderna och samarbete med Nordvästra Ryssland. Inom dessa områden har samarbetet egna prioriterade teman. Under perioden 2011-2014 har jämställdhetsarbetet två överordnade tvärgående teman nämligen integrering av ett köns- och jämställdhetsperspektiv samt mäns och pojkars aktiva deltagande. För samarbetet i Norden är de prioriterade områdena jämställdhet på arbetsmarknaden; jämställdhet i utbildning; kön, etnicitet och jämställdhet samt nolltolerans mot könsrelaterat våld. För samarbetet med Baltikum är de prioriterade temana jämställdhet på arbetsmarknaden, jämställdhetundervisning, jämställdhet $\mathrm{i}$ det offentliga rummet samt nolltolerans mot könsrelaterat våld. I Nordvästra Ryssland är de prioriterade temana jämställdhetsundervisning samt nolltolerans mot könsrelaterat våld.

Visionen för jämställdhetsarbetet i Nordiska ministerrådet är att vara en förebild för andra, och på internationell nivå synliggöra hur vi i Norden möter globaliseringens utmaningar just genom att genomföra en jämställdhetspolitik som säkrar hållbara samhällen - också i framtiden.

Ministerrådet for Kultur (MR-K). Nordisk ministerråd er en sentral plattform for kultursamarbeidet i Norden. Ministerrådets virksomhet på kulturområdet har forgreninger til annet formelt og uformelt nordisk samarbeid i og utenfor Norden. Det nordiske kultursamarbeidet skal forvalte nordisk kulturarv innen historie, kultur og språk og på denne måten sikre en kontinuitet. Samtidig skal nye kulturuttrykk og impulser innlemmes i dette samarbeidet. Endringer i kulturlivets og kunstens rammebetingelser, i befolkningssammenset- ning, teknologi med mer stiller krav om fleksibilitet og fornyelse.

Ministerrådets styringsdokumenter:

Strategien for Nordisk ministerråds kultursamarbeid 2013 - 2020 ble vedtatt av Ministerrådet for kultur den 31. oktober 2012. 
De fem temaene i strategien for det nordiske kultursamarbeidet for 20132020 er:

- Det bærekraftige Norden

- Det kreative Norden

- Det interkulturelle Norden

- Det unge Norden

- Det digitale Norden

Ved hjelp av disse overskriftene ønsker Ministerrådet for kultur å fange opp endringer og utfordringer i dagens samfunn generelt, og på kulturområdet spesielt. Temaene kompletterer og overlapper hverandre. Strategien skal tjene som styringsdokument for institusjoner og samarbeidsorganer innenfor Nordisk ministerråd.

Ministerrådet för Lagsamarbete (MR-LAG). Samarbejdet indenfor justitssektoren angår bl.a. forberedende lovgivningsarbejde, initiativer til forebyggelse og bekæmpelse af kriminalitet, samarbejde med hensyn til EU/EØS-ret, samt samarbejde med de retshåndhævende myndigheder i de baltiske stater.

Med henblik på en ensartet retlig udvikling i overensstemmelse med Helsingforsaftalens målsætninger og opfyldelse af justitssektorens samarbejdsprogram, gennemgås og drøftes aktuelle nordiske lovgivningsinitiativer.

Under Ministerrådet er etableret Nordisk Baltisk Kontaktgruppe (NBCG). NBCG har som overordnet formål at fremme og styrke det retlige samarbejde mellem de nordiske og de baltiske lande.

Ministerrådet för Miljø (MR-M) skal genom det nordiske miljøsamarbejde bidrage til at bevare og forbedre miljøkvalitet og livskvalitet i Norden, ha forvaltningsrelevans samt påvirke internationalt samarbejde. Udgangspunktet och vårt viktigaste styrdokument er miljøhandlingsprogrammet før perioden $2013-2018$.

Hovedtemaerne i miljøhandlingsprogrammet reflekterer områder, hvor Norden har en stærk tradition og interesse for fælles samarbejde, og samtidig er fremtidsorienteret: grön samfundsutveckling, klimatförändringar och 
luftföroreningar, biologisk mångfald och ekosystem samt hälsa och miljöfarliga kemikalier.

Norden og de nordiske landes miljøsamarbejde er i fokus og vil blive støttet primært gennem miljøarbetsgrupperne men også genom miljøfinansieringsbolaget NEFCO og miljømærket Svanen. Internationellt prioriteras samarbejdet med regionale organer fx. Arktisk Råd, Barentsrådet og HELCOM (Helsinki Commission), men også i EU och i internationella miljökonventioner och fx. i FN's miljøprogram UNEP.

Ministerrådet for Næring, Energi og Regionalpolitikk (MR-NER) skal på det erhvervspolitiske område først og fremmest sikre at fyrtårnsprojekterne under det nye samarbejdsprogram for 2014-2017 sættes i gang. Projekterne skal have fokus på at styrke den nordiske konkurrencekraft, herunder at skabe fælles viden, der kan styrke nordisk erhvervspolitik. Det gælder fx for områderne innovation i den offentlige sektor, behovsdreven innovation og entrepenørskab. Samarbejdsprogrammet for Innovations- og erhvervspolitik 2014-17 er blevet udarbejdet i løbet af 2013. Der vil også blive lagt vægt på at få prioriteringsindsatsen om bio-økonomi sat i gang.

MR-NER skal, via sit energipolitiske samarbejdsprogram for 2014-2017, bidrage til grønne vækstsamfund med stabil energiforsyning og bæredygtig energi til gavn for velfærden i de nordiske lande. Det nordiske energisamarbejde skal være et redskab til yderligere harmonisering af det nordiske elmarked og markedsføring af nordiske styrkepositioner på den globale arena. Der skal fortsat arbejdes målrettet med velfungerende energimarkeder og klimavenlige energisystemer, energieffektivisering og brug af vedvarende energikilder samt med udviklingen af mere miljøvenlige energikilder til transport på sø, land og i fiskerisektoren.

Det nordiska regionalpolitiska samarbetet skall bidra till att säkra en implementering av de regionalpolitiska målsättningarna. Regionalsektorn har tagit fram ett samarbetsprogram för perioden 2013 - 2016 som ska: 1) Bidra till en regionalt hållbar välfärdsutveckling 2) Främja en hållbar regional utveckling i Arktis 3) Stimulera en grön tillväxt i alla regioner.

Ministerrådet for Social og Sundhedspolitik (MR-S) har ansvar for Nordisk Ministerråds samarbejde inden for områderne social- og sundhedspolitik. I perioden 2010-2012 evaluerede de nordiske lande samarbejdet på området med den hensigt at planlægge på lang sigt og prioritere. 
Dette resulterede bl.a. i en ny strategi 2013 for nordisk samarbejde på social- og sundhedsområdet.

Samarbejdet i 2014 baseres på denne nye strategi, som har fire hovedmål:

- Sikre social tryghed i Norden på et arbejdsmarked under stadig forandring

- Målrettet indsats for forebyggelse

- Styrke kvalitet og sikkerhed i social- og sundhedsvæsenet

- Fremme innovation og forskning.

Som led i en politisk prioritering og for at sikre en synlig og målbar indsats koncentreres sektorens projektmidler for perioden 2013-2015 om temaet "Inkludering af udsatte unge i arbejdsliv og uddannelse". Temaet har baggrund i den økonomiske krise i Europa som har sat velfærdsstaten under pres og formålet er en bedre komparativ oversigt over politikker for at inkludere udsatte unge $\mathrm{i}$ arbejdslivet og uddannelse $\mathrm{i}$ de nordiske lande. Temaet sætter særlig fokus på den øgede andel unge med psykiske lidelser, som modtager førtidspension/uførepension.

Nordens velfærdscenter (NVC) er en vigtig aktør til at fremme udviklingen indenfor det velfærdspolitiske område i Norden og dets nærområder, samt at bidrage til at udvikle den nordiske velfærdsmodel i et globalt perspektiv.

I 2013 besluttede EK-S at indstille til MR-S og MR-SAM at nedlægge Nordic School of Public Health NHV (NHV) med sigte på at skolen skal afvikles senest den 1. januar 2015. I 2014 skal to organisationskomiteer arbejde med dette, en komite skal afvikle skolen og den anden udarbejde beslutningsgrundlag for de nordiske aktiviteter inden for folkesundhed. De nordiske lande ser det som yderst vigtigt at beholde ambitionsniveauet i det fortsatte nordiske samarbejde på folkesundhedsområdet.

Ministerrådet for Uddannelse og Forskning (MR-U) har ansvar for Nordisk Ministerråds samarbejde inden for områderne uddannelsespolitik og forskningspolitik, ligesom Ministerrådet koordinerer Nordisk Ministerråds samarbejde inden for områderne IT-politik og sprogpolitik.

En hovedprioritet for MR-U i 2014 er programmet Holdbar Nordisk Velford, som MR-U gennemfører i samarbejde med MR-S under prioriteringsbudgettet (se budgetpost 7-8210-2). 
Initiativer i relation til statsministrenes satsning på grøn vækst formuleret $\mathrm{i}$ pressemeddelelsen Norden - ledende i grøn vaekst er en anden vigtig prioritet. MR-U har ansvaret for at udvikle samarbejdet om uddannelse og forskning for grøn vækst og bidrager til udvikling af en række andre områder knyttet til grøn vækst (se budgetpost 7-8111-2).

Rapporten om gennemgangen af det nordiske forskningssamarbejde Vilja till forskning? danner grundlaget for MR-U's arbejde med at udvikle et mere effektivt, fokuseret og sektorovergribende samarbejde på forskningsområdet. I 2014 vil spørgsmål som udvikling af fælles forskningsinfrastruktur have høj prioritet.

Inden for Nordplus programmerne vil styrket information om og profilering af Nordplus samt spredning af resultater blive prioriteret i 2014.

MR-U vil i 2014 fortsætte sit samarbejde om arbejdsdeling og koncentration inden for højere uddannelse, ligesom diskussioner om finansiering, indhold og administration af Nordisk Master Program (NMP) fra 2015 vil præge året.

I 2014 vil der på sprogområdet primært blive arbejdet med revisionen af den nordiske sprogkonvention og implementering af den nye organiseringen af sprogområdet. 


\section{Prioriteringsbudget}

\section{Generel Indledning}

Samarbetsministrarna beslöt år 2013 att upprätta en prioriteringsbudget inom Nordiska ministerrådets budgetram. Budgettet för 2014 är 74,8 MDKK.

Prioriteringsbudgeten är uppdelad i två delar. En del som består av 30 MDKK som är öronmärkta till initiativ som initierats av det svenska och det isländska ordförandeskapen, och en övrig del på 44 MDKK. Prioriteringsbudgeten ska användas för att igångsätta nya, större och prioriterade satsningar. Under 2014 kommer fokus att ligga på de prioriterade satsningarna hos det isländska ordförandeskapet, samt områdena grön tillväxt, hälsa och välfärd samt en vidareföring av existerande globaliseringsinitiativ. De slutliga budgettexterna till de 3 isländska initiativen, Den nordiska spellistan, Välfärdsvakten och Bioekonomi-satsningen, blir först klara till ministerrådsförslaget i september.

\begin{tabular}{|c|c|c|c|c|c|}
\hline & \multirow{2}{*}{$\begin{array}{c}\text { Budget } \\
2014\end{array}$} & \multirow{2}{*}{$\begin{array}{c}\text { Budget } \\
2013\end{array}$} & \multicolumn{2}{|c|}{ Difference } \\
\hline & & & & $+/-$ & $\%$ \\
\hline \multicolumn{2}{|c|}{ Sum Prioriteringsbudgettet (TDKK) } & 74.768 & 81.441 & -6.673 & $-8,2 \%$ \\
\hline & Formandskapspuljen, Island & 15.240 & & 15.240 & - \\
\hline $7-8005-2$ & Den nordiska spellistan & 2.032 & & 2.032 & - \\
\hline $7-8006-2$ & Välfärdsvakten & 3.048 & & 3.048 & - \\
\hline \multirow[t]{2}{*}{$7-8007-2$} & Bioekonomi-satsningen & 10.160 & & 10.160 & - \\
\hline & Formandskapspuljen, Sverige & 15.240 & 20.360 & -5.120 & $-25,1 \%$ \\
\hline $7-8001-2$ & NordMin & 10.160 & 10.180 & -20 & $-0,2 \%$ \\
\hline $7-8002-2$ & $\begin{array}{l}\text { Fler unga i arbete i Norden och arbetsmak- } \\
\text { nadsmötet }\end{array}$ & 0 & 5.090 & -5.090 & - \\
\hline $7-8003-2$ & $\begin{array}{l}\text { Förbättrade emissionsinventeringar av kortli- } \\
\text { vade klimatpåvekande luftföreningar }\end{array}$ & 2.032 & 2.036 & -4 & $-0,2 \%$ \\
\hline \multirow[t]{2}{*}{$7-8004-2$} & Lärande på arbetsplats & 3.048 & 3.054 & -6 & $-0,2 \%$ \\
\hline & Prioriteringspuljen & 44.288 & 61.081 & -16.793 & $-27,5 \%$ \\
\hline $7-8110-1$ & Testcenter & 828 & 509 & 319 & $62,7 \%$ \\
\hline $7-8111-2$ & Uddannelse og forskning inden for grøn vækst & 3.759 & 8.653 & -4.894 & $-56,6 \%$ \\
\hline $7-8112-1$ & Elmarknaden & 1.173 & 3.054 & -1.881 & $-61,6 \%$ \\
\hline $7-8113-2$ & $\begin{array}{l}\text { Grønne tekniske normer og standarder - Nor- } \\
\text { den som standardmaker }\end{array}$ & 3.251 & 2.036 & 1.215 & $59,7 \%$ \\
\hline $7-8114-2$ & Grøn offentlig indkøb & 2.540 & 2.036 & 504 & $24,8 \%$ \\
\hline $7-8115-2$ & $\begin{array}{l}\text { Utveckla tekniker och metoder för avfallshan- } \\
\text { tering }\end{array}$ & 6.736 & 7.126 & -390 & $-5,5 \%$ \\
\hline
\end{tabular}




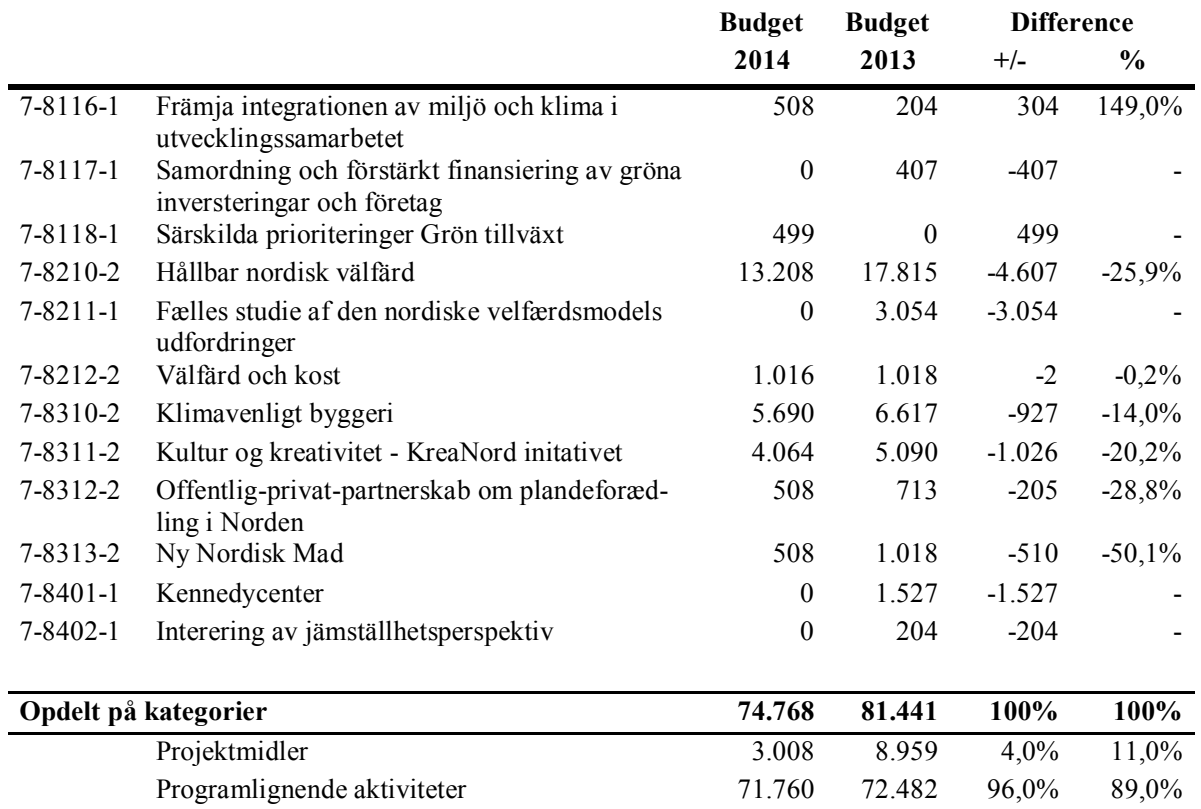

\section{7-8001-2 NordMin}

\begin{tabular}{|l|c|c|c|c|c|} 
Valuta & Budget 14 & Budget 13 & Budget 12 & Disp./bud. 12 & Bud.disp. af \\
\hline DKK & 10.160 .000 & 10.180 .000 & 0 & $0 \%$ & MR-NER
\end{tabular}

Formål
Det inrättas ett expertnätverk med syfte att föra samman aktörer inom den nordiska gruv- och mineralsektorn NordMin. Syftet med NordMin är att stärka en hållbar nordisk gruvnärings konkurrenskraft genom innovation, näringsutveckling och samverkan. NordMin ska synliggöra gruv- och mineralnäringens betydelse för en grön tillväxt i Norden. Nätverket ska fungera som en forsknings- och innovationsplattform för befintliga och framtida nordiska samarbeten inom området och kommer att utformas i dialog med aktörer inom industrin, akademin och från andra berörda myndigheter.

Prioriteringer i Fastställa olika styrdokument såsom en strategisk forsk2014 nings- och innovationsagenda, plan för workshopar och 
seminarier i syfte att diskutera frågor av vikt för branschens utveckling, en handlingsplan för fortsatt finansiering av nätverket och långsiktiga prioriteringar, identifiera och bjuda in fler organisationer i samarbetet samt bjuda in nationella program och projekt som kan ansluta till och utvecklas inom ramarna för NordMin. Genomföra en första utlysning av projektmedel.

Sekretariats- Luleå tekniska universitet (LTU). funktion

7-8002-2 Fler unga i arbete i Norden och arbetsmarknadsmötet

\begin{tabular}{|l|c|c|c|c|c|} 
Valuta & Budget 14 & Budget 13 & Budget 12 & Disp./bud. 12 & Bud.disp. af \\
\hline DKK & 0 & 5.090 .000 & 0 & $0 \%$ & $\begin{array}{c}\text { General- } \\
\text { sekretæren }\end{array}$
\end{tabular}

Budgetposten är nedlagd.

7-8003-2 Förbättrade emissionsinventeringar av kortlivade klimatpåverkande luftföroreningar

\begin{tabular}{|l|c|c|c|c|c|} 
Valuta & Budget 14 & Budget 13 & Budget 12 & Disp./bud. 12 & Bud.disp. af \\
\hline DKK & 2.032 .000 & 2.036 .000 & 0 & $0 \%$ & MR-M
\end{tabular}

Formål

Ett treårigt projekt för att förbättra de nordiska ländernas emissionsinventeringar av kortlivade klimatpåverkande luftföroreningar, s.k. SLCP (Short Lived Climate Pollutants). SLCP påverkar både klimatet och luftkvaliteten.

Syftet med projektet är att skapa förutsättningar för minskade halter av sot och troposfäriskt ozon i atmosfären genom bättre kunskap om utsläppens källor och omfattning genom att

• öka kunskapen om de faktiska utsläppen av SLCP från 
källor i Norden,

- harmonisera metodik för emissionsberäkningar för PM (fina partiklar) /BC (Black Carbon d.v.s. sot)från förbränningskällor

- identifiera de åtgärder för att minska utsläppen som är effektivast i respektive nordiskt land. Utsläppen av sot ska särskilt studeras,

- ge stöd till förhandlingar om ett avtal om sot inom ramen för Arktiska rådet

Åtgärder som föreslås ska vara kostnadseffektiva och genomförbara i de nordiska länderna. Projektet ska bygga vidare på och komplettera det metodutvecklingsarbete för emissionsinventeringar av sot som nu pågår i $\mathrm{FN}$ under UNECEs (United Nations Economic Commission for Europe) luftvårdskonvention LRTAP (Long Range Transboundary Air Pollution).

Uppdraget utförs som ett sammanhållet projekt med IVL Svenska Miljöinstitutet som projektledare.

Prioriteringer i Baserat på bakgrundsanalys, kartläggning och identifie2014 ring av kunskapsluckor under år 2013 inleds arbete med mätningar och emissionsinventeringar samt utveckling av emissionsfaktorer. Utformningen av emissionsfaktorerna ska beakta behov för uppföljning av miljömål i de nordiska länderna.

Förslag till åtgärder där fina partiklar och sot prioriteras tas fram.

7-8004-2 Lärande på arbetsplats

\begin{tabular}{|l|c|c|c|c|c|} 
Valuta & Budget 14 & Budget 13 & Budget 12 & Disp./bud. 12 & Bud.disp. af \\
\hline DKK & 3.048 .000 & 3.054 .000 & 0 & $0 \%$ & MR-U
\end{tabular}

Formål

Det 3-årige utviklingsprosjektet om læring på arbeidsplass, ledet av Skolverket i Sverige, har som formål å møte de utfordringer de nordiske landene står ovenfor 
knyttet til å sikre lærlinge- og praksisplasser og kvaliteten innen læring på arbeidsplass, samt å øke andelen som fullfører videregående opplæring.

Gjennom prosjektet legges det til rette for et samarbeid mellom lokale og regionale aktører, som skoler og skoleeiere, bedrifter, bransjeorganisasjoner, yrkesråd/nemder eller motsvarende, der formålet er erfaringsutveksling om kvalitet i læring på arbeidsplass i Norden. I tillegg til de lokale og regionale aktører er det etablert et samarbeid på nasjonalt nivå mellom de nasjonale myndigheter med ansvar for yrkesopplæring.

En målsetning med prosjektet er at erfaringene fra de lokale og regionale nivå blir drøftet på det nasjonale nivå, og kan bidra til økt viten og politikkutvikling på nasjonalt og nordisk nivå om læring på arbeidsplass.

Prioriteringer i 2014
- $\quad$ Legge til rette for samarbeid mellom lokale og regionale aktører i Norden om erfaringsutveksling om kvalitet i læring på arbeidsplass,

- Stimulere til et utviklingsarbeid om læring på arbeidsplass i Norden,

- Bidra til økt viten og politikkutvikling på nasjonalt og nordisk nivå om læring på arbeidsplass gjennom erfaringene fra de lokale og regionale nivå.

7-8005-2 Den nordiska spellistan

\begin{tabular}{|l|c|c|c|c|c|} 
Valuta & Budget 14 & Budget 13 & Budget 12 & Disp./bud. 12 & Bud.disp. af \\
\hline DKK & 2.032 .000 & 0 & 0 & $0 \%$ & MR-K
\end{tabular}

Formål

Projektet syftar till att synliggöra, marknadsföra och därmed öka exportmöjligheterna för nordisk musik till den nordiska publiken och vidare ut i världen. Ett ökat intresse för nordisk musik kan bidra till att stärka den nordiska musikmarknaden och öka sysselsättningsmöjligheterna inom musikbranschen. 
I detta ändamål har en nordisk spellista (The Nordic Playlist, NPL) utvecklats. Spellistan ska fungera som plattform för marknadsföringen 2014-2016.

Prioriteringer i Att genomföra fas 1 och därmed utveckla ett brand för 2014 den nordiska spellistan. Under 2014 genomförs en ett-årig kampanj för att hitta den bästa nya nordiska musiken och sammansätta en lista med 520 låtar utvalda av identifierade kuratorer. Kampanjen avslutas med en officiell lansering av den nordiska spellistan.

\section{7-8006-2 Välfärdsvakten}

\begin{tabular}{|l|c|c|c|c|c|} 
Valuta & Budget 14 & Budget 13 & Budget 12 & Disp./bud. 12 & Bud.disp. af \\
\hline DKK & 3.048 .000 & 0 & 0 & $0 \%$ & MR-S
\end{tabular}

Formål

Nordiska välfärdsvakten ska undersöka effekterna av finanskrisen på de nordiska välfärdssystemen; specifikt effekterna på hälsa, välfärd och deltagande i arbetsliv. Projektet syftar till att:

- Undersöka effekten av finanskrisen och dess konsekvenser för välfärdssystemen

- Bidra till öppna strategier för välfärdsfrågor och utveckla indikatorer för att följa utvecklingen av välfärdssystemen

- Bidra till att minska effekten av hälsorelaterade problem på välfärd samt öka hållbarheten i välfärdssystemen

Prioriteringer i Under 2014 kommer arbetet med den nordiska välfärds2014 vakten att inledas. De nordiska ländernas erfarenheter ska användas som underlag för forskning om effekterna av ökad ekonomisk börda, långvarig press och arbetslöshet på psykisk hälsa, välfärd och särskilda gruppers livsvillkor. Fokus kommer också ligga på att utvärdera de åtgärder som vidtagits under finanskriser i de nordiska länderna för att lära mer om hur negativa effekter på befolkningens hälsa och välfärd kan motverkas. 


\section{7-8007-2 Bioekonomi-satsningen}

\begin{tabular}{|l|c|c|c|c|c|} 
Valuta & Budget 14 & Budget 13 & Budget 12 & Disp./bud. 12 & Bud.disp. af \\
\hline DKK & 10.160 .000 & 0 & 0 & $0 \%$ & MR-FJLS
\end{tabular}

Formål

Bioekonomin är ett viktigt stöd i de ekonomiska systemen $i$ alla de nordiska länderna och en av hörnstenarna i grön ekonomisk tillväxt och hållbarhet. Bioekonomi bygger på ett ekonomiskt system där användningen av biobaserede produkter, restprodukter och andra produkter som uppstår under bearbetningen, maximeras för att minska avfallet $\mathrm{i}$ värdekedjan och trycket på miljön. Målet är också att göra de nya generationerna medvetna om viktigheten av grön tillväxt och hållbarhet.

Det nordiska initiativet om bioekonomi syftar till att:

- Reducera negativ miljöpåverkan och säkra hållbar användning av resurser inom alla samhällsområden

- Säkra medvetenheten om grön tillväxt och hållbar utveckling i ett långsiktigt perspektiv med nya initiativer var kreativitet används som forskningsoch undervisningsmetod.

- Reducera avfall och maximera utnyttjande och förtjänst av ekologiska produkter

- Främja innovation, grönt näringsliv och regional utveckling

- Öka förnybar energi i transportsektoren samt förnybar energi i fiske och godstransport till sjöss

- Förhindra avfallsproduktion samt öka återvinningen

Prioriteringer i Under 2014 fokuserar initiativet på att stärka det nordiska 2014 samarbetet kring nya initiativer med tvärsektoriellt sammarbete inom forskning, utveckling samt innovation. Detta ska ske i nära samarbete med industri och utbildningsinstitutioner. 


\section{8-8110-1 Testcenter}

\begin{tabular}{|l|c|c|c|c|c|} 
Valuta & Budget 14 & Budget 13 & Budget 12 & Disp./bud. 12 & Bud.disp. af \\
\hline DKK & 828.000 & 509.000 & 0 & $0 \%$ & MR-NER
\end{tabular}

Formål

At arbejde for at udvikle det nordiske samarbejde omkring eksisterende nationale ordninger, hvor grønne energiteknologier kan testes og udvikles i stor skala, samt at undersøge mulighederne for potentiel merværdi af at etablere nye fælles nordiske grønne test- og demonstrationsanlæg.

Der udarbejdes på nuværende tidspunkt en rapport om kortlægning af nordiske testcenter faciliteter. På baggrund af denne vil MR-NER på deres møde i oktober 2013 tage beslutning om en række anbefalinger til det fremtidige arbejde for Testcenter. Det kan have indflydelse på indholdet i budgetteksten.

Prioriteringer i Prioriteringerne i 2014 vil tage udgangspunkt i en kort2014 lægningsrapport om grønne testcentre og demonstrationsanlæg der forventes afsluttet i foråret 2013. På baggrund af denne rapport, der skal kortlægge eksisterende, nordiske grønne testfaciliteter indenfor energieffektivisering og vedvarende energi, vil EK-E efterfølgende udarbejde et forslag til opfølgning på opdraget fra de nordiske statsministre vedrørende fællesnordiske test- og demonstrationsfaciliteter af grønne energiteknologier.

\section{7-8111-2 Uddannelse og forskning inden for grøn vækst}

\begin{tabular}{|l|c|c|c|c|c|} 
Valuta & Budget 14 & Budget 13 & Budget 12 & Disp./bud. 12 & Bud.disp. af \\
\hline DKK & 3.759 .000 & 8.653 .000 & 0 & $0 \%$ & MR-U
\end{tabular}

Formål

Norden er i dag et af verdens førende regioner inden for grøn vækst og bæredygtig udvikling. Dette skyldes ikke mindst at der i de nordiske lande investeres i forskning og udvikling af grønne teknologier, og et relativt højt vidensniveau om bæredygtig udvikling i befolkningerne. 
Der foregår i dag et væld af tiltag og aktiviteter i krydsfeltet mellem uddannelse, forskning og innovation og bæredygtig udvikling i de nordiske lande.

For at styrke Nordens internationale førerposition og inspirere andre regioner og lande til bæredygtig udvikling, består en vigtig opgave $i$ at lære af, udnytte og profilere viden og erfaringer fra igangværende indsatser i Norden.

Prioriteringer i 2014
Med Topforskningsinitiativet (TFI) og den nordiske forskningssatsning for grøn vækst og bæredygtig udvikling, er der skabt bemærkelsesværdige resultater inden for bl.a. klima- og energiforskning. Efter TFI's afslutning i 2013 består en vigtig opgave i at formidle, profilere og udnytte erfaringer og resultaterne af TFI's forskningsresultater. Det gælder konkret om at videreføre TFI's forskning i et nyt rammeprogram om grøn vækst samt om at etablere en forskningsbaseret koordineringsplatform i NordForsk til at facilitere en bredere udnyttelse og formidling af den nordiske forskning for grøn vækst og bæredygtig udvikling.

Samtidig relanceres klimanorden.org som digital læringsplatform for undervisning i klima og bæredygtig udvikling på grund-, ungdoms- og voksenuddannelser i Norden. Portalen skal bidrage til øget viden, engagement og kompetencer inden for klima og bæredygtig udvikling og på sigt skabe grundlag for grøn vækst i Norden. Som en del af klimanorden.org relanceres den nordiske klimadag i 2014 i en ny form. Klimadagen skal inspirere og øge skolernes opmærksomhed på klimaudfordringerne og få børn og unge til at engagere sig i klimaspørgsmål og bæredygtig udvikling.

Endelig arrangeres i 2014 inspirations- og netværksseminarer om undervisning i bæredygtig udvikling for undervisere på grundskoler og ungdomsuddannelser.

EK-U vil hertil løbende tage stilling til yderligere konkrete uddannelses- og forskningsindsatser for grøn vækst. 
7-8112-1 Elmarknaden

\begin{tabular}{|l|c|c|c|c|c|} 
Valuta & BUDGET 14 & BUDGET 13 & BUDGET 12 & Disp./bud. 12 & Bud.disp. af \\
\hline DKK & 1.173 .000$. & 3.054 .000$. & 0. & $0 \%$. & MR-NER
\end{tabular}

Formål

I de nordiske statsministres initiativ om grøn vækst indgår initiativer til at fremme forbrugerfleksibilitet på det nordiske elmarked, og at fremme et samarbejde med ledende aktører inden for industri- og service sektoren for at dele erfaringer og best-practice $\mathrm{i}$ forbrugerfleksibilitet og energieffektivisering.

Prioriteringer i De nordiske statsministre prioriterer behovet for øget 2014 forbrugerfleksibilitet med brug af nye smarte grid teknologier på det fælles elmarked højt. Elmarkedsgruppen under MR-NER har igangsat en udredning der skal belyse mulighederne for at etablere en fælles strategi, der kan udnytte potentialet for forbrugerfleksibilitet, herunder i samspillet mellem elmarkedet og andre energimarkeder. Analysen og anbefalingerne skal præsenteres for MRNER i 2014 og det videre arbejde vil tage udgangspunkt i rapportens resultater. MR-NER vil i løbet af 2013 udarbejde en ny handlingsplan for energisektoren 2014-2017, og resultatet af dette arbejde vil have stor betydning for det energisektorens overordnede, fremtidige arbejde inden for grøn vækst.

7-8113-2 Grønne tekniske normer og standarder - Norden som standard$\underline{\text { maker }}$

\begin{tabular}{|l|c|c|c|c|c|} 
Valuta & Budget 14 & Budget 13 & Budget 12 & Disp./bud. 12 & Bud.disp. af \\
\hline DKK & 3.251 .000 & 2.036 .000 & 0 & $0 \%$ & MR-NER
\end{tabular}

Formål

Formålet med indsatsen er at fjerne barrierer for handel indenfor bæredygtigt byggeri ved at koordinere tekniske normer og standarder på visse områder og styrke den fælles indsats for gennemførelsen og videreudviklingen af 
de europæiske direktiver om energieffektivitet, der omhandler ecodesign og energimærkning. Indsatsen er delt op i en a-del(bæredygtigt byggeri) og bdel(energieffektivitet).

Prioriteringer i A-del (bæredygtigt byggeri):

Der gennemføres tre satsninger på henholdsvis:

1. Bæredygtig renovering af eksisterende bygninger

2. Indeklima og frivillige klassificeringsstandarder

3. Fremtidig EU regulering af produkt- og bygningsdeklarationer

Arbejdet gennemføres af de nationale standardiseringsmyndigheder i dialog med industrien og andre relevante aktører. Der forventes en væsentlig medfinansiering herfra.

Det undersøges om der kan skabes en øget nordisk nytte ved at koble satsningen til arbejdet med Nordisk svanemærkning. Arbejdet forventes afsluttet i 2014.

B-del (energieffektivitet):

Nedenstående er en gennemgang af b-delen, der sker gennem projektet Nordsyn. Nordisk Ministerråd gennemfører i 2013-2015 et treårigt projekt, Nordsyn, der skal føre til et øget og mere permanent samarbejde om markedskontrol af energirelaterede produkter. Hensigten er at støtte de nordiske forbrugere og producenter samt myndighederne i gennemførelsen af ecodesign- og energimærkningsdirektivet.

Ved forhandlingerne mellem Nordisk Ministerråd og Nordisk Råd om budgettet for 2014 er der opnået enighed om:

-at det innenfor budsjettpost 7-8113-2 (Grønne tekniske normer og standarder - Norden som standardmaker) også inkluderes en vurdering av en harmonisering i Nordisk byggningssektor. 
7-8114-2 Grønt offentligt indkøb

\begin{tabular}{|l|c|c|c|c|c|} 
Valuta & Budget 14 & Budget 13 & Budget 12 & Disp./bud. 12 & Bud.disp. af \\
\hline DKK & 2.540 .000 & 2.036 .000 & 0 & $0 \%$ & MR-NER
\end{tabular}

Formål

Insatsen ska adressera de viktigaste hindren för att realisera en innovativ offentlig miljöteknikupphandling: bättre koppla samman utbud och efterfrågan av miljöteknikresurser för att kunna öka tempot i utvecklingen av miljödrivna marknader samt säkerställa tillräckligt stora och ekonomiskt starka och uthålliga beställargrupper för att minska risktagandet för enskilda företag att våga satsa på utveckling av innovativ miljöteknik.

De nordiska ämbetsmannakommittéerna för näringspolitik samt miljöpolitik har i samarbete utarbetat en projektbeskrivning till ett förprojekt som under 2013 har undersökt möjligheterna att kordinera gröna inköpsstandarder i Norden. Förprojektet har satts igång i syfte att planera, förankra och beskriva ett samnordiskt huvudprojekt. Projektet drivs av Miljöstyrningsrådet (Sverige) i nära samarbetet med relevanta partners i de nordiska länderna för att praktiskt komma igång med ett nytt koncept för miljöteknik- och innovationsupphandlingar så att dessa upphandlingar kan breddas och fortgå av egen kraft utifrån ett marknadsdrivet perspektiv.

Prioriteringer i Genomföra det föreslagna huvudprojektet under perioden 2014 2013 - 2015 som bygger på resultaten och utgångspunkterna från det förprojekt som avslutades under 2013.

7-8115-1 Utveckla tekniker och metoder för avfallshantering

\begin{tabular}{|l|c|c|c|c|c|} 
Valuta & BUDGET 14 & BUDGET 13 & BUDGET 12 & Disp./bud. 12 & Bud.disp. af \\
\hline DKK & 6.736 .000 & 7.126 .000 & 0 & $0 \%$ & $\begin{array}{c}\text { MR-M/MR- } \\
\text { FJLS }\end{array}$
\end{tabular}

Formål

Budgetposten delas i två projekt. A-del med budget för 
2,9 MDKK och B-del med budget för 3,8 MDKK. A: Ett förprojekt har satts igång via Nordiska avfallsgruppen under miljösektorn. Förslaget ska se på ökad materialåtervinning av plast och textiler efter fyra fastlagda kriterier. Syftet med förprojektet är att utveckla ett flerårigt projekt som ska se på olika styrinstrument för att minska avfall men också utveckling av möjliga teknologier för att sortera och återanvända avfall ska undersökas.

B: Projektet om mattsvinn har till syfte att tydliggöra tänkbara vinster (ekonomiska, ekologiska och etiska) med ett minskat mattsvinn och att belysa eventuella hinder som finns i t.ex. tillämpningen av gällande EUlagstiftning och handelsnormer och vad som borde förändras för att möjliggöra dessa vinster. Avsikten är gemensamma insatser för att minska matsvinnet $i$ alla led från primärproduktion, via detaljhandel och fram till konsument.

Prioriteringer i A: Förprojektet ska avslutas med en workshop i syfte att 2014 förankra projektet i relevanta fora och att identifiera behov av forskning och utveckling för nya lösningar och beräknas vara klart i oktober 2012.

B: I ett samarbete mellan de nationella myndigheter och departement innan naturvård, livsmedel och jordbruk siktas det på att genomföra ett treårigt projekt som bland annat kommer kartlägga matavfall och matsvinn i primärproduktionen, och andra orsaker till matsvinn samt konkreta åtgärdsförslag och initiera nationella dialoger med livsmedelsbranschen, detaljhandeln och konsumentorganisationer. Dessutom planeras en avslutande gemensam workshop med inriktning på goda exempel på åtgärder för att minska matsvinnet men även bättre utnyttja de oundvikliga matavfallet för att öka biogasproduktion. 
7-8116-2 Främja integation av miljö och klimat i utvecklingssamarbetet

\begin{tabular}{|l|c|c|c|c|c|} 
Valuta & Budget 14 & Budget 13 & Budget 12 & Disp./bud. 12 & Bud.disp. af \\
\hline DKK & 508.000 & 204.000 & 0 & $0 \%$ & MR-M
\end{tabular}

Formål

De nordiska länderna är internationellt sett stora givare inom utvecklingssamarbete till utvecklingsländer och miljö och klimat är centrala delar i de nordiska ländernas biståndspolitik. De nordiska länderna kunden agera gemensamt genom våra biståndsorgan samt i samverkan med andra aktörer, inte minst i den privata sektorn.

Miljöministrarna är eniga om betydelsen av att främja integration av miljö- och klimat i utvecklingssamarbetet men noterar att i frågan ligger utanför miljöministrarnas mandat. I dialog med utvecklingsministrarna har man enats om att temat tas upp på dagordningen vid nästa möte mellan de nordiska utvecklingsministrarna.

NEFCO och NDF samarbetar sedan några år inom ramen för Nordic Climate Facility om klimatinsatser i fattiga utvecklingsländer.

I tillägg har de nordiska miljöministrarna godkänt att NEFCO i samarbete med NDF genomför pilotprojekt om så kallade NAMA:s (Nationally Appropriate Mitigation Actions). Två projekt, ett i Vietnam i cementsektorn och ett i Peru i avfallssektorn har redovisats på FN:s klimatmöten. Detta så kallade Nordic Partnership Initiative är unikt $\mathrm{i}$ världen och har fått stor internationell uppmärksamhet. Det är också ett gott exempel på samarbete mellan offentliga och privata aktörer i en innovativ finansering, sammanlagt omfattar projektet ca 3,9 miljoner $€$, och på att de nordiska länderna tar sitt ansvar för internationella förpliktelser inom klimatområdet. Miljöministrarna är eniga i att man bör se närmare på hur samarbetet mellan NEFCO och NDF kan stärkas.

Miljösektorn överväger under år 2013 dels en konferens 
om dessa klimatprojekt dels ett initiativ om samarbete mellan de nordiska länderna och några utvecklingsländer om borttagande av subventioner på fossila bränslen.

Prioriteringer i Under år 2014 förväntas en uppföljning av dessa initiativ 2014 samt fortsatt samarbete mellan NEFCO och NDF.

7-8117-1 Samordning och förstärkt finansiering av gröna investeringar och företag

\begin{tabular}{|l|c|c|c|c|c|} 
Valuta & Budget 14 & Budget 13 & Budget 12 & Disp./bud. 12 & Bud.disp. af \\
\hline DKK & 0 & 407.000 & 0 & $0 \%$ & MR-Finans
\end{tabular}

Budgetposten är nedlagd.

7-8118-1 Särskilda prioriteringer Grön tillväxt

\begin{tabular}{|l|c|c|c|c|c|} 
Valuta & Budget 14 & Budget 13 & Budget 12 & Disp./bud. 12 & Bud.disp. af \\
\hline DKK & 499.000 & 0 & 0 & $0 \%$ & $\begin{array}{c}\text { General- } \\
\text { sekretæren }\end{array}$
\end{tabular}

Formål I syfte att understödja statsministrarnas tvärsektoriella satsning på grön tillväxt genomförs det särskilda gemensamma profileringsåtgärder.

Prioriteringer i Dessa åtgärder är extraordinära insatser som under 2014 2014 planeras innefatta utarbetandet av ett elektroniskt magasin, samt arrangerandet av seminarier/konferenser med externa och interna intressenter som kan bidra till att profilera, vidareutveckla och finna synergier i den nordiska satsningen på grön tillväxt. 


\section{7-8210-2 Hållbar nordisk välfärd}

\begin{tabular}{|l|c|c|c|c|c|} 
Valuta & Budget 14 & Budget 13 & Budget 12 & Disp./bud. 12 & Bud.disp. af \\
\hline DKK & 13.208 .000 & 17.815 .000 & 0 & $0 \%$ & MR-S/MR-U
\end{tabular}

Formål

Hållbar nordisk välfärd syftar till att hitta innovativa lösningar för att förnya de nordiska välfärdssamfunden för Nordens 25 miljoner invånare. Lösningarna ska bidra till ökad kvalitet och jämlikhet i utbildning, arbete och hälsa och omsorg.

Detta uppnås genom finansiering av konkreta insatser och skapandet av nordiska plattformar för dialog och kunskapsutbyte. De lösningar som tas fram inom ramen för programmet synliggörs och profileras i och utanför Norden.

Programmet Hållbar nordisk välfärd har följande mål:

- idéer, inspiration och exempel på nya välfärdslösningar ska skapas

- utbildning ska leda till arbete

- tillgången på kompetens inom hälso- och omsorgssektorn ska säkras

- forskning om hälsa och välfärd ska främjas

- goda förutsättningar för utveckling och högre kvalitet i hälso- och sjukvård ska skapas

Programmets mål ska realiseras genom konkreta projekt och aktiviteter inom tre insatsområden:

1. Utbildning och arbete för välfärd

2. Forskning för välfärd

3. Infrastruktur för välfärd

Programmet tar sig an stora och komplexa uppgifter. En nordisk insats kan bara fungera som komplement till nationella och lokala insatser. Hållbar nordisk välfärd ska därför också bidra till att öppna upp för erfarenhetsutbyte och lärande mellan länderna inom de tre insatsområdenas fokuseringar. 
Prioriteringer i 2014
- Kommunicera programmets preliminära resultat och delta i välfärdsdebatten i Norden

- Igångsätta kompletterande insatser inom de tre insatsområdena

- Möjliggöra erfarenhetsutbyte och lärande mellan de nordiska länderna på området.

Ved forhandlingerne mellem Nordisk Ministerråd og Nordisk Råd om budgettet for 2014 er der opnået enighed om:

- at der er behov for et nordisk studie for at se på patienternes frie bevægelighed $\mathrm{i}$ Norden når det nye EUdirektiv (Directive on Cross Border Health Care) er implementeret $\mathrm{i}$ landene og de første erfaringer er indhøstet. Spørgsmålet vil indgå i NMR's store $2013-2015$ program, Holdbar Nordisk Velfærd, herunder vurderes i den gennemgang av samarbejdet på sundhedsområdet som nu gennemføres.

7-8211-1 Fælles studie af den nordiske velfærdsmodels udfordringer

\begin{tabular}{|l|c|c|c|c|c|} 
Valuta & Budget 14 & Budget 13 & Budget 12 & Disp./bud. 12 & Bud.disp. af \\
\hline DKK & 0 & 3.054 .000 & 0 & $0 \%$ & MR-A
\end{tabular}

Budgetposten er nedlagt.

7-8212-2 Välfärd och kost

\begin{tabular}{|l|c|c|c|c|c|} 
Valuta & Budget 14 & Budget 13 & Budget 12 & Disp./bud. 12 & Bud.disp. af \\
\hline DKK & 1.016 .000 & 1.018 .000 & 0 & $0 \%$ & MR-FLJS
\end{tabular}

Formål

"Den nordiska handlingsplanen för kost och motion" från 2006 føljes upp på så sätt:

○ Att de nu snart färdigställda nordiska näringsre-

kommendationerna omsätts till konkreta kostråd 
med fokus mot olika sociala grupper i samhället, så att önskad effekt av kostråden uppnås. I en nyligen genomförd undersökning framgår att det föreligger stora skillnader i matval mellan olika grupper och att man som följd av det kan se skillnader i utvecklingen av övervikt och fetma. För att nå bästa resultat behöver olika metoder och kommunikationssätt utvecklas. Dessutom är det viktigt att rekommendationerna anpassas till matvaruval och måltidsmönster.

○ Nyckelhålet är ett viktigt verktyg för att kommunicera kostråden och måste kontinuerligt vidareutvecklas och moderniseras för att nå nya målgrupper och nya områden. Med modernisering avses också utveckling av olika kommunikationsformer och kanalval för att nå ut till olika målgrupper. Nyckelhålet röner ett stort internationellt intresse som sätter Norden i fokus.

- Det framgår också att det är skillnader i matvanor mellan kvinnor och män, liksom att det finns en skillnader beroende på utbildningsnivå och också mellan etniska grupper i samhället, vilket öppnar för samarbete med andra kommittéer (Jämställhet och Social).

Prioriteringer i Lanceringen af de nordiske næringsrekommendationer i 2014 2013 betyder i 2014 at der fokuseres på hvordan de nordiske lande kan inspirere hinanden $i$ arbejdet med at omsætte disse til konkrete kostråd, og hvordan den videre kommunikation af kostrådene kan nå ud til alle de relevante grupper. Det nordiske ernæringsmærke - nøglehulsmærket - skal indgå i disse overvejelser. Et tværgående samarbejde skal indgå i, herunder integrering af ligestilling.

Sekretariats- Den varetages i et samspil mellem nordisk ministerrådsfunktion sekretariat og en af de arbejdsgrupper, der hører under EK FJLS (Levnedsmidler): NKMT (Nordisk arbejdsgruppe for fødevarer, ernæring og toksikologi). 
7-8310-2 Klimavenligt byggeri

\begin{tabular}{|l|c|c|c|c|c|} 
Valuta & Budget 14 & Budget 13 & Budget 12 & Disp./bud. 12 & Bud.disp. af \\
\hline DKK & 5.690 .000 & 6.617 .000 & 0 & $0 \%$ & EK-NER
\end{tabular}

Formål

Et fællesnordisk innovationsprogram for klimavenligt byggeri. Programmet skal styrke udviklingen af Norden som foregangsregion indenfor klimavenligt byggeri, og være med til at sikre innovation, vækst og eksport på området. Programmet skal have en tæt tilknytning til markedet, og være i samspil med nationale programmer og satsninger på området

Prioriteringer i 2014

Sekretariatsfunktion

- Fortsættelse af Modul 3 (fælles nordisk call for proposals som bygger videre på eksisterende nationale indsatser) og monitorering/opfølgning på projekterne herunder.

- Gennemførelse af Nordic Built Arena 3 (konference med deltagelse fra ledelsesniveau fra underskriverne af Nordic Built Charter)

- Strategisk fokus og initiativer på den internationale dimension af Nordic Built, i.e. eksport og øget international konkurrenceevne for den nordiske byggebranche.

- Fortsat promovering af Nordic Built Charter og Nordic Built og forankring af Nordic Built i den nordiske byggebranche

- Analyse af potentialet i og gennemførelse af en Challenge 2

Nordic Innovation varetager sekretariatsfunktionen

7-8311 Kultur og kreativitet - KreaNord initiativet

\begin{tabular}{|l|c|c|c|c|c|} 
Valuta & Budget 14 & Budget 13 & Budget 12 & Disp./bud. 12 & Bud.disp. af \\
\hline DKK & 4.064 .000 & 5.090 .000 & 0 & $0 \%$ & EK- \\
& & & & & NER/MR-K
\end{tabular}


KreaNord er etableret som et nordisk tværsektorielt samlingspunkt for udveksling af erfaringer, viden og udviklingsvisioner for både erhvervs- og kultursektoren.

Formålet med KreaNord er at styrke mulighederne for vækst, beskæftigelse og eksport i de kreative industrier i Norden.

KreaNord skal inden for det afsatte budget skabe øget værdi i de kreative industrier i Norden, der samtidigt bidrager til vækst og innovation i kunst- og kulturlivet samt i det øvrige erhvervsliv. KreaNord skal bidrage til bedre koordinering mellem de nordiske landes politikudvikling.

I 2010 fik KreaNord opbakning fra de nordiske næringsog kulturministre til fire policy anbefalinger som ramme for arbejdet:

1. Fremme det strategiske samarbejde mellem og inden for de nordiske kreative og kulturelle industrier og det øvrige erhvervsliv

2. Fremme nye muligheder for finansiering, adgang til det globale marked og tiltrækning af udenlandske investorer til de kulturelle og kreative industrier i Norden

3. Fremme kultur og kreativitet på alle uddannelsesniveauer i Norden samt fremme kompetenceudviklingen inden for iværksætteri og forretningsudvikling på de kreative og kunstneriske uddannelser.

4. Etableringen af et fælles nordisk marked for kulturelle produkter og tjenester

Prioriteringer i KreaNord arbejder i 2014 med den videre implementerin2014 gen af anbefalingerne. KreaNord skal:

- skabe øget værdi og mulighed for nye forretningsmodeller i de kreative industrier i Norden, der samtidigt bidrager til vækst og innovation $i$ kunst- og kulturlivet samt i det øvrige erhvervsliv. Konkret arbejder KreaNord videre med det etablerede program fra 2013, som giver bidrag til større nordiske samarbejdsprojekter for at styrke 
de kreative erhverv.

- være en stærk nordisk platform og et samlingspunkt for udveksling af erfaringer, viden og dannelse af strategiske partnerskaber

- danne ramme om samarbejde mellem myndighederne i de nordiske lande, private virksomheder, kreative og kulturelle entreprenører og uddannelsesinstitutioner

- bidrage til at koble de nordiske landes nationale satsninger på området og i tæt samarbejde hjælpe hinanden til at indtage en førerposition i forhold til at forstå og udvikle de kreative og kulturelle erhverv i Norden og i relation til EU-initiativer.

- bidra til å synliggjøre Norden som frontløper innenfor de kulturelle og kreative industrier

\section{7-8312-2 Offentligt-privat-partnerskab om planteforædling i Norden}

\begin{tabular}{|l|c|c|c|c|c|} 
Valuta & Budget 14 & Budget 13 & Budget 12 & Disp./bud. 12 & Bud.disp. af \\
\hline DKK & 508.000 & 713.000 & 0 & $0 \%$ & MR-FJLS
\end{tabular}

Formål

MR-FJLS igangsatte i 2011 et offentligt-privatpartnerskab om planteforædling i Norden. Formålet med parterskabet er, at revitalisere den nordiske planteforædling for at styrke landenes tilpasning til klimaforandringer og er samtidig et væsentligt element i ministerrådets arbejde med bioøkonomi. Målet med budgetposten er, at sikre en stabil sekretariatsdækning af partnerskabet og dets aktiviteter, som finansieres med 50 procent fra landene og 50 procent fra virksomhederne. Sekretariatsbetjeningen af partnerskabet varetages af NordGen.

Partnerskabet blev etableret som et pilotprojekt for perioden 2011-13. MR-FJLS skal på sit møde i juni 2013 træffe beslutning om rammerne for partnerskabet fra $2014 \mathrm{og}$ frem, hvilket sker på baggrund af en evaluering, som gennemføres i foråret 2013. 
Prioriteringer i Arbejdet med partnerskabet i 2013 vil have to hovedspor, 2014 dels videreudvikling af de konkrete samarbejdsprojekter, og dels arbejdet med videreførelsen af partnerskabet efter de nye rammer, som besluttes af MR-FJLS i juni 2013.

Sekretariats- NordGen varetager sekretariatsfunktionen for det offentfunktion lig-private-partnerskab om planteforædling i Norden.

\section{7-8313-2 Ny Nordisk Mad}

\begin{tabular}{|l|c|c|c|c|c|} 
Valuta & Budget 14 & Budget 13 & Budget 12 & Disp./bud. 12 & Bud.disp. af \\
\hline DKK & 508.000 & 1.018 .000 & 0 & $0 \%$ & MR-FLJS
\end{tabular}

Formål

Ny Nordisk Mad er en konkret værdiskabende og innovativ satsning, der med udgangspunkt i Manifest for et nyt nordisk køkken, har til formål, at styrke det tværsektorielle samarbejde, som favner mad, kultur, kreative industrier, turisme og erhverv med henblik på at skabe ny inspiration. Indsatsen under denne budgetpost relaterer sig til budgetpost 3-6420-2 Ny Nordisk Mad, og skal bidrage til at synliggøre det nordiske arbejde med Ny Nordisk Mad i og uden for Norden.

Prioriteringer i Prioriteringerne for indsatsen under denne budgetpost 2014 fastlægges ultimo 2013, men følger af rammeprogrammet for Ny Nordisk Mad II 2010-2014.

7-8401-1 Kennedycenter (Nordic Cool)

\begin{tabular}{|l|c|c|c|c|c|} 
Valuta & Budget 14 & Budget 13 & Budget 12 & Disp./bud. 12 & Bud.disp. af \\
\hline DKK & 0 & 1.527 .000 & 0 & $0 \%$ & $\begin{array}{c}\text { NSK/MR- } \\
\text { SAM }\end{array}$
\end{tabular}

Budgetposten er nedlagt. 
7-8402-1 Integrering av jämställdhetsperspektiv

\begin{tabular}{|l|c|c|c|c|c|} 
Valuta & Budget 14 & Budget 13 & Budget 12 & Disp./bud. 12 & Bud.disp. af \\
\hline DKK & 0 & 204.000 & 0 & $0 \%$ & ÄK-JÄM
\end{tabular}

För jämställdhetsintegrering av projekten i prioriteringsbudgeten 2013 beviljade NSK 204 TDKK och ÄK-JÄM 300 TDKK, d.v.s. totalt 504 TDKK. Arbetet är för närvarande pågående. Beviljningen var primärt en engångssatsning eftersom alla sektorer i NMR själva bär ansvaret för att arbeta med jämställdhetsintegrering. 


\section{Kulturpolitik}

\section{Generel indledning}

Generelt Nordisk Ministerråd er en central platform for kultursamarbejdet i Norden. Ministerrådets virksomhed på kulturområdet har forgreninger til andet formelt og uformelt nordisk samarbejde i og udenfor Norden.

Det nordiske kultursamarbejde skal forvalte nordisk kulturarv indenfor historie, kultur og sprog og på denne måde sikre en kontinuitet. Samtidig skal nye kulturudtryk og impulser have plads i samarbejdet. Ændringer i kulturlivets og kunstens rammebetingelser, i befolkningssammensætning, teknologi med mere stiller krav om fleksibilitet og fornyelse. Der vil være behov for mere forskning og kundskabsunderlag når kulturpolitikken skal udformes og iværksættes.

Gennem erfarings.- og kompetenceudvikling samt netværksdannelse skal Norden som region udvikles og styrkes. Sprogforståelsen i Norden skal fremmes. Principperne om ytringsfrihed og armslængdeafstand skal forsvares. Kultursamarbejdet skal fremme en bæredygtig udvikling. Et bredt forankret kultursamarbejde skal udvikle fællesskab og forståelse mellem indbyggerne i Norden og dermed bidrage til sammenhængskraft i de nordiske velfærdssamfund. Samspillet mellem det nordiske og det nationale niveau skal styrkes, sådan at den nordiske indsats får mest mulig gennemslagskraft.

Udmøntning af Som ett led i den beslutade besparingen på 5 procent på besparelse i Nordiska ministerrådets totala budget för 2014, har MR-K budget 2014 har beslutat att bidraget till Nordisk Journalistisk Efteruddannelse, som 2013 uppgår till 2675000 DKK, upphör från och med 1 januari 2014. Budgetpost 1-2223-2 Nordisk Journalistisk Efteruddannelse läggs därmed ned.

Det görs vidare en besparing på budgetpost 1-2203-3 Dispositionsmedel Kultur med 1 miljon DKK. Det görs en 
Ministerrådets styringsdokumenter besparing på budgetpost 2208 Strategiska satsningar med 665000 DKK.

På budgetposterna Nordisk barn- och ungdomskommitté, Nordiskt datorspelsprogram, Nordens hus i Reykjavik, Nordens hus på Färöarna, Nordens institut på Åland, Nordens institut på Grönland och Kulturkontakt Nord görs en pro rata besparing med 3,5 procent.

MR-K har vidare beslutat att neddragningen på administrationskostnader för ovanstående institutioner och samarbetsorgan genomförs genom en fördelningsnyckel som baserar sig på antalet anställda i dessa.

De fem temaer i strategien for det nordiske kultursamarbejde 2013 - 2020 er

1. Det holdbare Norden

2. Det kreative Norden

3. Det interkulturelle Norden

4. Det unge Norden

5. Det digitale Norden

Sådan realiseres strategien:

- I Mål- og resultatkontrakter for Nordisk Ministerråds institutioner og samarbejdsorganer på kulturområdet

- I det årlige formandskabsprogram for kultursektoren

- Ved et årligt kulturforum

- Ved at dialogen intensiveres på alle niveauer

- Ved at samarbejdet mellem de nationale kulturmyndigheder og det nordiske kultursamarbejde styrkes

- I budgettekster som angiver prioriteringer for kommende år

- I de strategiske satsninger som MR-K vedtager

Resumé af Ministerrådets resultater i 2012
Følgende kan opsummeres som vigtigste resultater i 2012:

- Der er vedtaget Strategi for Nordisk Kultursamarbejde $2013-2020$ i en grundig og involverende proces 
- Konklusionerne af 2011-evalueringen af kulturreformen er fulgt op: Der er indledt differentieret dialog med mange aktører indenfor kultursamarbejdet, spørgsmålet om amatør og frivilliges deltagelse i kultursamarbejdet er blevet undersøgt og der er skabt bedre muligheder for politiske prioriteringer og for realisering af strategien med oprettelse af budgetposten strategiske satsninger.

- I 2012 har pågået forberedelser til ministerrådets omfattende engagement i Nordic Cool festivalen på Kennedy Center i Washington i februar/marts 2013 hvor nordisk kunst og kultur blev promoveret.

- Ministerrådet for kultur har engageret sig i udformningen af Nordisk strategi för hållbar utveckling, Ett gott liv i ett hållbart Norden, og har fået inkluderet kultur i strategien.

- En ny Nordisk Råds pris for Børne- og ungdomslitteratur blev en realitet i 2012. Indstiftelsen af prisen er resultatet af de nordiske kulturministres mangeårige ønske om styrke og løfte børne- og ungdomslitteraturen i Norden. Prisen er en del af et samlet løft der blandt andet betyder flere penge til oversættelse af bøger, forfatterskole for unge og forfatterbesøg på skoler i Norden.

- Formandskabet 2012 afholdte en række seminarer og workshops, blandt andet som led i forberedelserne af ny strategi for kultursamarbejdet. Fokuspunkter: Behovet for mere forskning på kulturområdet, arkitektur og byplanlægning, bibliotekernes rolle som mødeplads, interkulturalitet, nye udfordringer på medieområdet og kultur og bæredygtig udvikling

- Under Bog- og biblioteksmessen i Göteborg, som havde Norden som tema, deltog Ministerrådet for kultur med finansiering af en række aktiviteter, der udover litterære aktiviteter gjaldt en stor satsning på temaet Kultur og identitet i samarbejde med Nordisk Råd samt paneldiskussion fotoudstilling og mediesamtale om hvordan mennesker med funktionsnedsættelse fremstilles i medierne.

- Der blev i juni 2012 afholdt Nordisk Kulturforum i et 
nyt format som skal sikre den fremtidige realisering af strategi for kultursamarbejdet.

De nordiska husen, instituten, medieinstitutionerna och ministerrådets rådgivande organ på barn- och ungdomsområdet har var för sig haft en omfattande verksamhet under året varav en del redogörs för nedan:

Kulturkontakt Nord (KKN) har under året arbetat med utveckling av det nordiska biblioteket till en kulturell mötesplats med arrangemang som författaraftnar, filmaftnar och utställningar; seminarier och diskussionsarrangemang fokuserade på Nordiska rådets priser och Ny Nordisk Mat; arrangemang för barn och unga med utställningar, teater, språkcafé och språkverkstad; TING-festivalen i samband med Nordiska rådets session i Helsingfors. Kultur- och konstprogrammet och Nordiskt-baltiskt mobilitetsprogram mottog 1463 ansökningar 2012, vilket är en liten minskning jämfört med 2011 (1472). Enligt sakkunniggrupperna har kvaliteten höjts på ansökningarna vilket har gjort att man beviljat fler projekt stöd jämfört med 2011.

Nordens hus i Reykjavik (NOREY). MR-K har beslutat att Norey ska koordinera och administrera det nya lyftet för barn- och ungdomslitteratur, inklusive det nyinstiftade Nordiska rådets pris för barn- och ungdomslitteratur. Norey har även fortsatt utveckla det nordiska biblioteket som har ökat utlånen med 25 procent sedan 2010. Norey arrangerade den Västnordiska dagen, en tredagars kulturfestival med konst, film, dans, och Västnordisk mat med syfte att profilera det moderna och innovativa Västnorden. Norey arrangerade den nordiska barnboksfestivalen Matur uti i Myrin och, i samarbete med Reykjavik International Film Festival, Iceland Airwaves samt Reykjavik Jazz festival. Dessutom utställningar med konst, mode och design.

Nordens hus på Färöarna (NHFÖ) har under året fortsatt arbetet med kultur i skolan på Färöarna, Listaleypurin. Projektet genomförs i samarbete med Undervisningsministeriet och kommunernas landsförening. NHFÖ har samarbetat med de andra nordiska husen om containerut- 
ställningen Norden rundt - kunst fra Iskantens rand. Huset har även arrangerat ungdomsbiennalen Ung i Färöarna; samordnat arbetet med att producera kortfilmer om ungas syn på det hållbara samhället till Nordic Cool 2013; samarbetat med konstnär Trondur Paterson om utsmyckning av Kennedy Center i samband med Nordic Cool 2013; deltagit på bokmässan i Frankfurt och Göteborg för att presentera färöisk litteratur.

Nordens institut på Grönland (NAPA) har under 2012 genomfört flera projekt och insatser med barn och unga som målgrupp. Bland dessa kan nämnas Arctic Winter Games som är ett möte kring sport och kultur för unga i den arktiska regionen samt Outervision som är ett ett stort dansarrangemang som genomfördes i samverkan med dansinstitutet Bårdar (Norge) och Katuaq.

Nordens institut på Åland (NIP ̊). Barn och unga är en prioriterad målgrupp. NIPÅ har bland annat arrangerat skrivarverkstäder samt workshops kring design och genomfört projektet Yo!BaNa (Young Baltic Narratives) som syftar till att stärka barn och ungdomars möjlighet att göra film och ha film som fritidssysselsättning på öarna. Genom det treåriga projektets gång har över 100 filmer producerats.

Nordiska barn- och ungdomskommittén (NORDBUK) har under 2012 gjort insatser för att stärka ungas organisering, nordisk identitet samt kunskap om ungas situation. Genom ett programkontor fördelas projekt och organisationsbidrag i syfte att stärka nordisk identitet och ungas organisering. 11 organisationsbidrag har beviljats med sammantaget 1,4 MDKK. 29 projektbidrag beviljades med sammantaget 3,7 MDKK. NORDBUK har initierat en översikt om vad som görs i de nordiska länderna för att motverka ungdomsarbetslöshet och marginalisering samt en förstudie om barnfattigdom. NORDBUK gjorde även insatser kring jämställdhet, exempelvis genom ett expertseminarium om ungdom och jämställdhet. Flera insatser har också skett för att stärka ungas organisering. För att främja ett barn- 
och ungdomsperspektiv inom Nordiska ministerrådets olika verksamheter har NORDBUK deltagit i olika arbetsgrupper samt fört dialog med olika kommittéer och verksamhetsområden inom Nordiska ministerrådet.

Nordiska Datorspelsprogrammet har arbetat med global marknadsföring av nordiska datorspel genom Game Developers Conference i San Francisco, Nordic Gamekonferensen i Malmö, och GamesCom i Köln. Vidareutvecklat nätverksarbetet för branschorganisationerna $\mathrm{i}$ Norden, arrangerat en Nordisk speldag med 121 deltagande nordiska bibliotek. Administration av utvecklingsstöd till nordiska datorspel från Norden 2012. Under verksamhetsåret bildades Nordic Game Institute (Stiftelse som från 2013 förvaltar Nordiska Datorspelprogrammet, skapad av de fem nordiska ländernas nationella branschorganisationer för datorspel).

Nordisk Film och TV Fond; kvalitetsgranskning och utdelning av stöd till produktion och distribution som stimulans av nordisk film- och TV produktion. High Five Cross Media For Kids; tvärmedialt kvalitetsinnehåll för nordiska barn (film-TV-spel-mobiltelefoner och online-aktiviteter). Digitaliseringsprojekt i Nordamerika för utvalda nordiska filmer. Nordisk talang- och Master Class - möte mellan avgångselever vid nordiska filmskolor möter branschens professionella kring projektförslag och idéer. Nordisk High Five; stöd till fem nordiska distributionsverksamheter. Medverkan i festivaler, seminarier och branschmöten.

Nordiskt informationscenter för medie- och kommunikationsforskning (NORDICOM); utvecklingen av den nya långsiktiga strategin för kultur; organiserar hearing med fokus på utvecklingen av nordisk kulturstatistik; fokus på barn och unga och medier med stärkt kunskapsutbyte på den globala arenan; underlag av relevans för kunskapsförmedling från forskningen om mediernas roll och villkor i samhället till olika brukargrupper i Norden, Europa och övriga världen; översikter och analyser rörande trender i 
medieutvecklingen i Norden för olika brukargrupper i Norden, Europa och övriga världen.

Nordiska Journalist Centret har som överordnat uppdrag att via kurser, seminarier och andra kompetensutvecklande initiativ för journalister och redaktörer i Norden, skapa och utveckla vetande och förståelse kring nordisk samhörighet och kulturell gemenskap i en alltmer globaliserad värld; pressens roll som demokratins väktare i det moderna Norden; spridning av nordiska mediers erfarenhet med pressfrihet till bland annat Nordvästryssland; understödjande av den nordiska språkförståelsen. Nordiska Journalist Centret har genom ett särskilt projekt finansierat av MR-Sam, avseende Nordvästryssland, genomfört aktiviteter för utveckling av dialogen mellan nordiska och nordvästryska journalister och redaktörer, kring demokrati och pressfrihet.

\begin{tabular}{|c|c|c|c|c|c|}
\hline & & Budget & Budget & Diffe & rence \\
\hline & & 2014 & 2013 & $+/-$ & $\%$ \\
\hline Sum MR & K (TDKK) & 167.879 & 173.335 & -5.456 & $-3,1 \%$ \\
\hline & Generelle kulturinnsatser & 46.416 & 48.648 & -2.232 & $-4,6 \%$ \\
\hline $1-2203-1$ & Dispositionsmidler Kultur & 1.028 & 2.012 & -984 & $-48,9 \%$ \\
\hline $1-2205-2$ & Nordisk kulturfond & 34.525 & 35.274 & -749 & $-2,1 \%$ \\
\hline $1-2206-2$ & Nordisk Råds priser & 3.530 & 2.419 & 1.111 & $45,9 \%$ \\
\hline $1-2208-1$ & Strategiska satsningar & 7.333 & 8.943 & -1.610 & $-18,0 \%$ \\
\hline & Barn och unga & 6.068 & 6.195 & -127 & $-2,1 \%$ \\
\hline & Projektmedel och generella stödordningar & 6.068 & 6.195 & -127 & $-2,1 \%$ \\
\hline $1-2212-2$ & $\begin{array}{l}\text { Nordisk Børne- og Ungdomskomité } \\
\text { (NORDBUK) }\end{array}$ & 6.068 & 6.195 & -127 & $-2,1 \%$ \\
\hline & Film och media & 37.207 & 39.488 & -2.281 & $-5,8 \%$ \\
\hline & Projektmedel och generella stödordningar & 34.063 & 36.478 & -2.415 & $-6,6 \%$ \\
\hline $1-2221-2$ & Nordisk computerspilprogram & 6.610 & 6.782 & -172 & $-2,5 \%$ \\
\hline $1-2222-2$ & Nordisk Film- och TV-fond & 27.453 & 27.021 & 432 & $1,6 \%$ \\
\hline $1-2223-2$ & Nordisk Journalistisk Efteruddannelse & 0 & 2.675 & -2.675 & - \\
\hline & Institutioner & 3.144 & 3.010 & 134 & $4,5 \%$ \\
\hline $1-2228-3$ & NORDICOM & 3.144 & 3.010 & 134 & $4,5 \%$ \\
\hline & Konstområdet & 74.486 & 75.360 & -874 & $-1,2 \%$ \\
\hline & Projektmedel och generella stödordningar & 32.719 & 32.203 & 516 & $1,6 \%$ \\
\hline $1-2251-2$ & Kultur- og kunstprogrammet & 17.523 & 17.247 & 276 & $1,6 \%$ \\
\hline $1-2253-2$ & Nordisk oversættelsesstøtte & 3.022 & 2.974 & 48 & $1,6 \%$ \\
\hline $1-2254-2$ & $\begin{array}{l}\text { Nordiskt-baltiskt mobilitetsprogram för } \\
\text { Kultur }\end{array}$ & 12.174 & 11.982 & 192 & $1,6 \%$ \\
\hline
\end{tabular}




\begin{tabular}{llrrrr} 
& & Budget & \multicolumn{2}{c}{ Budget } & \multicolumn{2}{c}{ Difference } \\
& $\mathbf{2 0 1 4}$ & \multicolumn{1}{c}{$\mathbf{2 0 1 3}$} & \multicolumn{1}{c}{+ - } & \multicolumn{1}{c}{$\%$} \\
\hline \multirow{2}{*}{$1-2270-3$} & Nordiska kulturhus (institutioner) & 41.767 & 43.157 & -1.390 & $-3,2 \%$ \\
$1-2272-3$ & Nordens hus i Reykjavik & 8.412 & 8.779 & -367 & $-4,2 \%$ \\
$1-2274-3$ & Nordens institut på Åland & 13.330 & 13.731 & -401 & $-2,9 \%$ \\
$1-2277-3$ & Nordens institut på Grönland (NAPA) & 2.895 & 3.011 & -116 & $-3,9 \%$ \\
$1-2548-3$ & 6.247 & 6.408 & -161 & $-2,5 \%$ \\
& Kulturkontakt Nord & 10.883 & 11.228 & -345 & $-3,1 \%$ \\
& Andra kultursatsningar & 3.702 & 3.644 & 58 & $1,6 \%$ \\
\hline \multirow{2}{*}{$1-2234-4$} & Projektmedel och generella stödordningar & 3.702 & 3.644 & 58 & $1,6 \%$ \\
& Samisk samarbeid & 3.702 & 3.644 & 58 & $1,6 \%$ \\
& & & & & \\
\hline Opdelt på kategorier & $\mathbf{1 6 7 . 8 7 9}$ & $\mathbf{1 7 3 . 3 3 5}$ & $\mathbf{1 0 0 \%}$ & $\mathbf{1 0 0 \%}$ \\
\hline & Projektmidler & 8.361 & 10.955 & $5,0 \%$ & $6,3 \%$ \\
& Programlignende aktiviteter & 110.905 & 112.569 & $66,1 \%$ & $64,9 \%$ \\
& Institutioner & 44.911 & 46.167 & $26,8 \%$ & $26,6 \%$ \\
& Organisationsbidrag & 3.702 & 3.644 & $2,2 \%$ & $2,1 \%$
\end{tabular}

\section{Generelle Kultursatsningar}

\section{1-2203-1 Dispositonsmidler Kultur}

\begin{tabular}{|l|c|c|c|c|c|} 
Valuta & Budget 14 & Budget 13 & Budget 12 & Disp./bud. 12 & Bud.disp. af \\
\hline DKK & 1.028 .000 & 2.012 .000 & 12.425 .000 & $98 \%$ & MR-K/ÄK-K
\end{tabular}

Formål

Budgetposten skal dække en række aktiviteter og politiske initiativer, herunder udgifter til policygrupper, arbeidsgrupper m.m.

Prioriteringer i Policygrupper og andre politiske initiativer 2014

\section{1-2204-1 Nordisk Kulturforum}

\begin{tabular}{|l|c|c|c|c|c|} 
Valuta & Budget 14 & Budget 13 & Budget 12 & Disp./bud. 12 & Bud.disp. af \\
\hline DKK & 0 & 0 & 1.627 .000 & $83 \%$ & MR-K/ ̈厶K-K
\end{tabular}

Formål 


\section{1-2205-2 Nordisk Kulturfond}

\begin{tabular}{|l|c|c|c|c|c|} 
Valuta & Budget 14 & Budget 13 & Budget 12 & Disp./bud. 12 & Bud.disp. af \\
\hline DKK & 34.525 .000 & 35.274 .000 & 34.650 .000 & $100 \%$ & Fondstyret
\end{tabular}

Formål

Nordisk Kulturfonds formål er at fremme det kulturelle samarbejde mellem de nordiske lande ved at bevilge bidrag til samarbejdsprojekter inden for almen kultur og kunst. Fondens virksomhed baserer sig på en aftale mellem de nordiske lande, der blev indgået i 1966.

Prioriteringer i Nordisk Kulturfond støtter i 2014 nordisk kultursamar2014 bejde i det professionelle kulturliv og i frivilligsektoren med særlig prioritering af:

- Aktiviteter som konkret fremmer børn og unges aktive deltagelse i det nordiske samarbejde om kunst og kultur.

- Aktiviteter som gennem kunst og kultur, æstetiske og kunstneriske processer/metoder bidrager til at øge nabosprogsforståelsen i Norden.

- Aktiviteter der bidrager til mangfoldig inkludering og deltagelse i det nordiske kultursamarbejde, samt aktiviteter der afspejler et mangfoldigt nordisk nutidigt fælleskab.

- Aktiviteter der gennemføres i tyndt befolkede områder, såsom Vestnorden og de nordlige og østlige områder i Norden.

Det forventes, at sekretariatet skal behandle ca. 1200 ansøgninger og administrere ca. 250 bevillinger. Fonden vil i 2014 arbejde proaktivt for at generere ansøgninger inden for de prioriterede områder, blandt andet ved at skabe nordiske mødepladser i form af workshops og medvirke til dannelsen af nordiske netværk.

Nordisk Kulturfond sætter i 2014 fokus på digital kunst og kultur og har reserveret tre mio. DKK til Årets Nordiske Kulturbegivenhed, DIGITAL 2015-2016. Med DIGITAL 2015-2016 ønsker Nordisk Kulturfond at give et 
løft til aktører, som vil skabe ny kunst og nye udtryk med udgangspunkt i digitale medier, metoder og teknologi. Fonden vil bevilge støtten til et nordisk samarbejde, som skaber, producerer og formidler kunst og kultur digitalt. Med denne satsning vil Nordisk Kulturfond stimulere arenaer, hvor samvirke mellem kunst og teknologi fører til udvikling og nye muligheder.

Årets Nordiske Børn- og Unge Festival vil finde sted i august 2014, men da det er en ambulerende festival, vil arrangementet være synligt over store dele af Norden. Fonden bevilgede i 2012 tre mio. DKK til projektet.

Ved forhandlingerne mellem Nordisk Ministerråd og Nordisk Råd om budgettet for 2014 er der opnået enighed om:

-at udrede, om der er effektiviserings- og rationaliseringsgevinster ved at sammenlægge Nordisk Kulturfond og Kulturkontakt Nord, herunder effekterne og fordele og ulemper for det kulturpolitiske arbejde.

Sekretariatsfunktion

Nordisk kulturfonds sekretariat

1-2206-2 Nordisk Råds priser

\begin{tabular}{|l|c|c|c|c|c|} 
Valuta & Budget 14 & Budget 13 & Budget 12 & Disp./bud. 12 & Bud.disp. af \\
\hline DKK & 3.530 .000 & 2.419 .000 & 2.376 .000 & $100 \%$ & MR-K/ÄK-K
\end{tabular}

Formål

Denna budgetpost samlar beviljningarna för de fyra nordiska kulturpriserna; Nordiska rådets barn- och ungdomslitteratur, Nordiska rådets litteraturpris, filmpris och musikpris under en och samma budgetpost. Ökningen av budgetposten hänför sig till kostnader för det från 2013 instiftade barn- och ungdomlitteraturpriset. Medlen är överförda från budgetpost 1-2208-1 Strategiska satsningar.

Budgetposten upprättades 2009 för att bidra till att synliggöra den viktiga satsning som priserna representerar innanför det nordiska kultursamarbetet och till att skapa 
samarbete och synergieffekter mellan priserna och deras profilering.

Budgetposten omfattar:

- prisbeloppen för barn- och ungdomslitteratur-, musik-, litteratur- och filmpriserna

- administrativa kostnader för priserna genom prissekretariaten

- arvode och reseutgifter till bedömningskommittéerna

- $\quad$ kostnader för synliggörande och marknadsföring av priserna

Prioriteringer i 2014
- Administrera priserna enligt prisstadgarna, samt fungera som sekretariat för prisernas bedömningskommittéer

- Synliggöra, profilera marknadsföra priserna till relevanta professionella aktörer och för en bred publik både i Norden och i övriga världen i tätt samarbete med Nordiska ministerrådets kommunikationsavdelning

- Skapa samarbete och synergieffekter mellan priserna

Sekretariats- Sekretariatsfunktionerna tillvaratas av:

funktion
- Nordiska rådets barn- och ungdomslitteraturpris:

Nordens hus i Reykjavik

- Nordiska rådets litteraturpris: Nordiska rådets delegation vid Sveriges riksdag

- Nordiska rådets filmpris: Nordiska Film- och TVfonden

- Nordiska rådets musikpris: Nordens hus på Färöarna

\section{1-2207-1 Kulturministrenes globaliseringsindsatser}

\begin{tabular}{|l|c|c|c|c|c|} 
Valuta & Budget 14 & Budget 13 & Budget 12 & Disp./bud. 12 & Bud.disp. af \\
\hline DKK & 0 & 0 & 1.658 .000 & $100 \%$ & MR-K/ÄK-K
\end{tabular}


Formål Budgetposten är nedlagd. Medlen överfördes 2013 till budgetpost 2208 Strategiska satsningar.

\section{1-2208-1 Strategiska satsningar}

\begin{tabular}{|l|c|c|c|c|c|} 
Valuta & Budget 14 & Budget 13 & Budget 12 & Disp./bud. 12 & Bud.disp. af \\
\hline DKK & 7.333 .000 & 8.943 .000 & 0 & $0 \%$ & MR-K/ÄK-K
\end{tabular}

Formål

Budgetposten upprättades 2012. Syftet är att samla resurser för att realisera kulturministrarnas strategiska satsningar under året. Insatserna ska vara kopplade till Strategi för det nordiska kultursamarbetet 2013 - 2020 vars överordnade teman är Det hållbara Norden, Det unga Norden, Det digitala Norden, Det kreativa Norden och Det interkulturella Norden. Medlen ska även användas till ordförandeskapsaktiviteter och konferenser som belyser arbetet med att realisera strategin.

Prioriteringer i 2014
- $\quad$ Ett lyft för nordisk barn- och ungdomslitteratur

- Nordisk musikexport

- Nordisk dansplattform

- Kreativa näringar

- Kultur och hälsa

- Ordförandeskapsaktiviteter

- Årligt forum om det nordiska kultursamarbetet

Ved forhandlingerne mellem Nordisk Ministerråd og Nordisk Råd om budgettet for 2014 er der opnået enighed om:

-at Nordisk Journalistcenter tilføres 1,0 MDKK til at fremme journalistiske opgaver med klare og tydelige nordiske formål. Ordningerne skal finansieres fra post 12208-1 Strategiska satsningar. 


\section{Børn og Unge}

\section{1-2212-2 Nordisk Børne- og Ungdomskomité (NORDBUK)}

\begin{tabular}{|l|c|c|c|c|c|} 
Valuta & Budget 14 & Budget 13 & Budget 12 & Disp./bud. 12 & Bud.disp. af \\
\hline DKK & 6.068 .000 & 6.195 .000 & 6.085 .000 & $93 \%$ & NORDBUK
\end{tabular}

Formål

Nordiska barn- och ungdomskommittén (NORDBUK) är Nordiska ministerrådets rådgivande och samordnande organ. NORDBUK: s verksamhet styrs av strategi för barn och unga i Norden. Strategin kompletteras av stadgar och en handlingsplan. Till detta tillkommer årliga aktivitetsplaner av ordförandelandet. NORDBUK har också ett uppföljande ansvar genom att analysera hur barn och unga är synliga i ministerrådets verksamheter. En rapport lämnas till MR-SAM varje år med rekommendationer och slutsatser. Rapporten består av beskrivningar på vad som skett utifrån ett antal prioriterade områden, resultat från ordförandeskapets aktiviteter, bidragsgivning samt resultat från nordiska institut och institutioner. I rapporten finns även NORDBUK:s rekommendationer och planerade insatser. Kulturkontakt Nord är programkontor för NORDBUK:s projekt och organisationsbidrag.

Prioriteringer i Under 2013 utvärderades aktuell handlingsplan och en ny 2014 handlingsplan togs fram. Under 2014 kommer NORDBUK att påbörja arbetet efter den nya handlingsplanen. NORDBUK kommer fortsatt att göra särskilda insatser kring:

- Projektbidrag till ungdomsverksamhet

- Organisationsbidrag till ungdomsorganisationer

- Öka kunskap om barn och ungas situation (särskilt fokus på unga utanför skola och arbete samt barnfattigdom)

- Främja det tvärsektoriella arbetet

Sekretariats-

funktion Kulturkontakt Nord 


\section{Film og Media}

\section{1-2221-2 Nordisk computerspilprogram}

\begin{tabular}{|l|c|c|c|c|c|} 
Valuta & Budget 14 & Budget 13 & Budget 12 & Disp./bud. 12 & Bud.disp. af \\
\hline DKK & 6.610 .000 & 6.782 .000 & 9.162 .000 & $99 \%$ & MR-K/ÄK-K
\end{tabular}

Formål

Utvecklingsstödet ska säkra tillgången till nordiska spel för barn och unga genom att ge direkt stöd till utvecklingen av nya kreativa datorspel.

Prioriteringer i - Nordic Game-konferensen ska ge nordiska spel2014 utvecklare möjlighet till erfarenhetsutbyte, kompetensutveckling, nätverksuppbyggnad och ger nordisk synlighet och gemenskap i en global industri.

- Exportaktiviteterna ska hjälpa nordiska spelutvecklare att få ut sina produkter på den globala marknaden.

- Arbetet för breddad finansiering ska säkra ett varaktigt nordiskt samarbete inom datorspelområdet genom att utöka antalet finansierande parter av skilda slag.

Ledelse og Planlagte udgifter 2014: 900.000

admin.

Faktiske udgifter 2012: 1.668.815

Sekretariats- Nordic Game Institute funktion

\section{1-2222-2 Nordisk Film- og TV-fond}

\begin{tabular}{|l|c|c|c|c|c|} 
Valuta & Budget 14 & Budget 13 & Budget 12 & Disp./bud. 12 & Bud.disp. af \\
\hline DKK & 27.453 .000 & 27.021 .000 & 26.543 .000 & $100 \%$ & MR-K/ÄK-K
\end{tabular}

Formål

Nordisk Film \& TV Fond (NFTF) har til opgave at fremme produktion og distribution af nordiske audiovisuelle værker (film og TV). Særligt hensyn tages til produktioner rettet til børn og unge. 
NFTF fungerer i øvrigt som sekretariat for Nordisk Råds filmpris og administrerer prisen på DKK 350.000.

NFTF administrerer tillige en bevilling til Filmkontakt Nord på DKK 1.400.000 i 2013 års priser. Filmkontakt Nord er et samarbejde mellem Nordisk Ministerråd og de nordiske filminstitutter med henblik på at promovere nordiske kort- og dokumentarfilm internationalt.

Prioriteringer i Fondsstyrets prioriteringer for virksomheden er gældende 2014 for hele aftaleperioden, 2010-2015, og virksomheden specificerer således ikke prioriteringer for enkelte år.

- Fremme produktion og distribution af nordiske audiovisuelle værker af høj kvalitet.

- Inspirere og styrke det kreative samarbejde på filmområdet indenfor de nordiske lande.

- Styrke produktion og spredning af kvalitative nordiske børnefilm.

Ledelse og Planlagte udgifter: Samme nivå som 2012

admin. $\quad$ Faktiske udgifter 2012: 4.561.258 DKK

Sekretariats- Nordisk Film \& TV Fonds sekretariat funktion

1-2223-2 Nordisk Journalistisk Efteruddannelse

\begin{tabular}{|l|c|c|c|c|c|} 
Valuta & Budget 14 & Budget 13 & Budget 12 & Disp./bud. 12 & Bud.disp. af \\
\hline DKK & 0 & 2.675 .000 & 2.628 .000 & $100 \%$ & MR-K/ÄK-K
\end{tabular}

Formål Verksamhetsbidraget till Nordisk Journalistisk Efteruddannelse upphör från och med 1 januari 2014 med hänvisning till den allmänna budgetneddragningen och kultur-ministrarnas politiska prioriteringar.

Ved forhandlingerne mellem Nordisk Ministerråd og Nordisk Råd om budgettet for 2014 er der opnået enighed om:

-at Nordisk Journalistcenter tilføres 1,0 MDKK til at fremme journalistiske opgaver med klare og tydelige 
nordiske formål. Ordningerne skal finansieres fra post 12208-1 Strategiska satsningar.

\section{1-2228-3 NORDICOM}

\begin{tabular}{|l|c|c|c|c|c|} 
Valuta & Budget 14 & Budget 13 & Budget 12 & NMR fin. 12 & Bud.disp. af \\
\hline SEK & 3.614 .000 & & & & MR-K/ÄK-K \\
\hline $\begin{array}{l}\text { Modsv. } \\
\text { DKK }\end{array}$ & 3.144 .000 & 3.010 .000 & 2.951 .000 & $34 \%$ &
\end{tabular}

Formål

Nordicom har til opgave gennem informations- og dokumentationsvirksomhed at fremme og videreudvikle det nordiske samarbejde på forskningsområdet medier og kommunikation.

Prioriteringer i Via forskellige kanaler skal Nordicom formidle viden om 2014 medieforskningen til forskellige brugergrupper i samfundet, samt fremme kontakterne mellem nordiske forskere og internationale forskningsmiljøer. NORDICOM är en central aktör för att realisera temat det Digitala Norden i Strategi för det nordiska kultursamarbetet 2013-2020.

- Dokumentation av medieforskningen i de nordiska länderna.

- Dokumentation av medieutvecklingen i de nordiska länderna.

- Kunskapsförmedling inom medieområdet till brukare i Norden, Europa och övriga världen.

Kontrakt-

2013-2015

periode

Kontrakt- Uppfyllt

status

Økonomi Inga anmärkningar

Ledelse og Planlagte udgifter: Samme nivå som 2012

adm.

Faktiske udgifter 2012: 560.000 DKK 


\section{Kunstområdet}

\section{$\underline{\text { 1-2251-2 Kultur- og Kunstprogrammet }}$}

\begin{tabular}{|l|c|c|c|c|c|} 
Valuta & Budget 14 & Budget 13 & Budget 12 & Disp./bud. 12 & Bud.disp. af \\
\hline DKK & 17.523 .000 & 17.247 .000 & 17.942 .000 & $99 \%$ & $\begin{array}{c}\text { Sakkunnig- } \\
\text { gruppen }\end{array}$
\end{tabular}

Formål

Kultur- och konstprogrammet är ett ramprogram som pågår 2012-2016. Programmet beviljar bidrag till projekt från alla kultur- och konstfält. Kvalitet och nytänkande är väsentliga kriterier vid utdelningen av stöd. Programmet har två delar, så kallade moduler.

Produktionsinriktad verksamhet

Denna modul är avsedd för projekt som satsar på kulturoch konstproduktioner samt kreativt arbete. Nyckelordet är innovation, vilket innebär utveckling och testning av nya idéer, koncept och processer.

Kompetensutveckling

Denna modul är avsedd för projekt som satsar på utbyte av information och kompetensutveckling för aktörerna inom kultur- och konstfältet. Detta kan ske i form av t.ex. seminarier, kurser eller workshops.

I budgetposten ingår också medel till Orkester Norden och Nordisk biblioteksvecka med 1000000 DKK respektive 500000 DKK i 2013 års priser.

Prioriteringer i Prioriteringar i Kultur- och konstprogrammet skall reflek2014 tera temana i Strategi for det nordiske kultursamarbete 2013-2020 (prioriteringarna är sido-ordnade)

- Det hållbare Norden

- Det kreativa Norden

- Det interkulturella Norden

- Det unga Norden

- Det digitala Norden

Ledelse og Planlagte udgifter: Samme nivå som 2012 admin. Faktiske udgifter 2012: 63.000 EUR 
Sekretariats- Kulturkontakt Nord funktion

\section{1-2253-2 Nordisk oversættelsesstøtte}

\begin{tabular}{|l|c|c|c|c|c|} 
Valuta & Budget 14 & Budget 13 & Budget 12 & Disp./bud. 12 & Bud.disp. af \\
\hline DKK & 3.022 .000 & 2.974 .000 & 2.921 .000 & $100 \%$ & $\begin{array}{c}\text { Sakkunnig- } \\
\text { gruppen }\end{array}$
\end{tabular}

Formål

Denne budgetposter blev etableret i 2010, og har til hensigt at synliggøre og lyfte frem oversættelsestøtten til nordisk litteratur.

I 2014 er DKK 300.000 øremærket oversættelse af børneog ungdomslitteratur.

Støtteordningens formål er at bidrage til flere udgivelser af kvalitetslitteratur på andre nordiske sprog end originalsproget.

Nätverket för de nordiska litteraturcentralerna (NORDLIT) handlägger översättningsstödet mellan de nordiska länderna och Färöarna, Grönland och Åland.

Kulturstyrelsen i Danmark är koordinator för nätverket och stödordningen.

Prioriteringer i 2014

Sekretariats- Kulturstyrelsen, Danmark
- Av bidraget ska 300000 DKK öronmärkas för utgivning av litteratur för barn och unga

- De mindre språkområdena (Färöarna, Grönland och det samiska språkområdet) i Norden 
1-2254-2 Nordiskt-baltiskt mobilitetsprogram för Kultur

\begin{tabular}{|l|c|c|c|c|c|} 
Valuta & Budget 14 & Budget 13 & Budget 12 & Disp./bud. 12 & Bud.disp. af \\
\hline DKK & 12.174 .000 & 11.982 .000 & 11.770 .000 & $100 \%$ & $\begin{array}{c}\text { Sakkunnig- } \\
\text { gruppen }\end{array}$
\end{tabular}

Formål

Det nordisk-baltiska mobilitetsprogrammet 2012-2014 är ett tvärsektoriellt ramprogram som beviljar mobilitetsstöd för kultur- och konstaktörer, stöder nätverksbildande inom konst- och kulturfältet samt bidrar till utveckling av konstnärsresidenscentra. Programmet är öppet för professionella konstnärer, utövare, förmedlare, producenter och kulturaktörer från alla sektorer inom konst- och kulturfältet inklusive kulturarv.

Mobilitetsprogrammet bidrar till att förstärka existerande nordisk-baltiskt samarbete. De övergripande principerna vad gäller såväl finansiering som styrning baseras på deltagande på lika villkor.

Finansieringen av programmet sker likvärdigt med bidrag från de baltiska länderna och Nordiska ministerrådet. Dessutom tilldelas ett särskilt bidrag från Nordiska ministerrådets grannlandsbudget. I 2013 uppgick grannlandsbudgetens bidrag till ca 750000 DKK.

Skandinavisk Forenings Kunstnerhus i Rom får ett ettårigt bidrag på DKK 900.000 i 2013 års priser inom ramen för denna budgetpost.

Prioriteringer i I løbet af 2014 skal det politisk besluttes om programmet 2014 skal fortsætte efter 2014 og i hvilken form det eventuelt skal ske.

Ledelse og Planlagte udgifter: Samme nivå som 2012

admin. Faktiske udgifter 2012: 106.000 EUR

Sekretariats- Kulturkontakt Nord funktion 


\section{Nordiske Kulturhus}

\section{1-2270-3 Nordens hus i Reykjavik}

\begin{tabular}{|l|c|c|c|c|c|} 
Valuta & Budget 14 & Budget 13 & Budget 12 & NMR fin. 12 & Bud.disp. af \\
\hline ISK & 182.870 .000 & 186.787 .000 & - & - & Institutionen \\
\hline $\begin{array}{l}\text { Modsv. } \\
\text { DKK }\end{array}$ & 8.412 .000 & 8.779 .000 & - & - &
\end{tabular}

Formål

Nordens Hus i Reykjavik (NOREY) startede sin virksomhed i 1968. Huset skal være et nordisk kulturcenter og et bindeled mellem Island og de øvrige nordiske lande.

NOREY är en central aktör i realiseringen av kulturministrarnas Strategi för det nordiska kultursmarbetet 20132020.

Biblioteket står som husets kernevirksomhed.

Under 2012 utbetalades verksamhetsbidraget till Nordens hus i Reykjavik på 8,5 MDKK från budgetpost 1-2203-1 Dispositionsmedel Kultur.

Prioriteringer i 2014

Kontraktperiode

Kontrakt- Uppfyllt status

Økonomi Inga anmärkningar

2011-2013
- Barn och unga - delaktighet och engagemang

- Litteratur och språk - ett modernt nordiskt bibliotek och sekretariat för Nordiska rådets barn- och ungdomslitteraturpris

- Internationell kunskap och kultur - Norden i världen, världen i Norden

- Lokal kulturkontaktpunkt - nätverksbygge och information

- Långsiktig hållbarhet - som innovatör med lokal och regional strategi

- Husets underhåll - arkitektur i centrum 
Ledelse og Planlagte udgifter: Samme nivå som 2012

adm.

Faktiske udgifter 2012: 42.431 .000 ISK

1-2272-3 Nordens hus på Färöarna

\begin{tabular}{|l|c|c|c|c|c|} 
Valuta & Budget 14 & Budget 13 & Budget 12 & NMR fin. 12 & Bud.disp. af \\
\hline DKK & 13.330 .000 & 13.731 .000 & 13.462 .000 & $67 \%$ & Institutionen
\end{tabular}

Formål

Nordens Hus på Færøerne (NHFÖ) startede sin virksomhed i 1983. Huset opgave er at formidle nordisk kultur på Færøerne og færøsk kultur i de øvrige nordiske lande, samtidig med at huset har en vigtig funktion som færøsk kulturhus. Nordens hus på Färöarna är en central aktör i realiseringen av kulturministrarnas Strategi för det nordiska kultursmarbetet 2013-2020. Nordens Hus på Færøerne administrerer Nordisk Råds musikpris.

Prioriteringer i 2014

Kontraktperiode

Kontrakt- Uppfyllt

status

Økonomi Inga anmärkningar

Ledelse og Planlagte udgifter: Samme nivå som 2012 adm.
- Kulturprojekter for børn

- Kulturprojekter for voksne

- Lokal kulturkontaktpunkt og Nordisk Råds musikpris

- Kultur og erhverv

- Vedligehold af huset

2012-2014

Faktiske udgifter 2012: 3.325.000 
1-2274-3 Nordens Institut på Åland

\begin{tabular}{|l|c|c|c|c|c|} 
Valuta & Budget 14 & Budget 13 & Budget 12 & NMR fin. 12 & Bud.disp. af \\
\hline EUR & 388.100 & 404.700 & 394.800 & $77 \%$ & Institutionen \\
\hline $\begin{array}{l}\text { Modsv. } \\
\text { DKK }\end{array}$ & 2.895 .000 & 3.011 .000 & 2.941 .000 & &
\end{tabular}

Formål

Nordens Institut på Åland (NIP $\AA$ ) etablerades 1984 och har som uppgift att främja det åländska kulturlivet i samspel med kulturlivet i det övriga Norden och i samarbete med lokala kulturorganisationer.

Institutet skall även främja kontakten och utväxling mellan Åland och det övriga Norden. NIPÅ är en central aktör i realiseringen av kulturministrarnas Strategi för det nordiska kultursmarbetet 2013-2020.

Prioriteringer i 2014

Kontraktperiode

Kontrakt- Uppfyllt status

Økonomi Inga anmärkninagr

Ledelse og Planlagte udgifter: Samme nivå som 2012 adm.
- Förmedling av nordisk konst och kultur till Åland samt kulturutväxling

- Kulturell mångfald och interkulturell dialog

- Barn och unga

- Lokal kulturkontaktpunkt - information och nätverksbygge

2012-2014

Faktiske udgifter 2012: 94.200 EUR

\section{$\underline{\text { 1-2277-3 Nordens Institut på Grönland (NAPA) }}$}

\begin{tabular}{|l|c|c|c|c|c|} 
Valuta & Budget 14 & Budget 13 & Budget 12 & NMR fin. 12 & Bud.disp. af \\
\hline DKK & 6.247 .000 & 6.408 .000 & 6.282 .000 & $86 \%$ & Institutionen
\end{tabular}

Formål

Nordens institut på Grönland (NAPA) etablerades 1986 i 
samarbete med Grönlands självstyre och Nuuks kommun. Institutets syfte är att stärka det grönländska kulturlivet, deltagande i nordisk sammarbete och utveckla sammarbete mellan Grönland och de övriga nordiska länderna, med särskilt fokus på kultur. Barn och unga är en prioriterad målgrupp. NAPA är en central aktör i realiseringen av kulturministrarnas Strategi för det nordiska kultursmarbetet 2013-2020.

Prioriteringer i 2014
- Barn och ungdomsprojekt

- Fortsatt utveckling av kulturarrangeman på Grönland och i Norden.

- Lokalt kulturkontaktpunkt för Kultur- och konstprogrammet samt Nordisk-Baltisk Mobilitetsprogram

$\begin{aligned} & \text { Kontrakt- } \\ & \text { periode }\end{aligned}$
$2012-2014$

Kontrakt- Uppfyllt

status

Økonomi Inga anmärkningar

Ledelse og Planlagte udgifter: Samme nivå som 2012

adm. Faktiske udgifter 2012: 1.260.000

\section{1-2548-3 Kulturkontakt Nord}

\begin{tabular}{|l|c|c|c|c|c|} 
Valuta & Budget 14 & Budget 13 & Budget 12 & NMR fin. 12 & Bud.disp. af \\
\hline EUR & 1.458 .800 & 1.509 .100 & 855.400 & $88 \%$ & Institutionen \\
\hline $\begin{array}{l}\text { Modsv. } \\
\text { DKK }\end{array}$ & 10.883 .000 & 11.228 .000 & 10.969 .000 & &
\end{tabular}

Formål

Kulturkontakt Nord (KKN) etablerades 2012 genom en sammanläggning av Kulturkontakt Nord och Nordens institut i Finland. KKN är en central aktör i realiseringen av kulturministrarnas Strategi för det nordiska kultursmarbetet 2013-2020. 
Kulturkontakt Nords syfte är att:

- utgöra en central nordisk kulturell mötesplats med syfte att stärka nordisk språklig och kulturell närvaro i Finland och i det övriga Norden

- fungera som administrativt sekretariat för Nordiska ministerrådets program

- profilera det nordiska kultursamarbetet, både i Norden och internationellt.

\section{Prioriteringer $\mathrm{i}$}

2014

Kontrakt-

periode

Kontrakt- Uppfyllt

status

Økonomi Inga anmärkningar

Ledelse og Planlagte udgifter: Samme nivå som 2012 adm.
- Nordisk mötesplats

- Programadministration

- Information och kommunikation

Ved forhandlingerne mellem Nordisk Ministerråd og Nordisk Råd om budgettet for 2014 er der opnået enighed om:

- at udrede, om der er effektiviserings- og rationaliseringsgevinster ved at sammenlægge Nordisk Kulturfond og Kulturkontakt Nord, herunder effekterne og fordele og ulemper for det kulturpolitiske arbejde.

2013-2015

Faktiske udgifter 2012: 101.000 EUR. 


\section{Andra kultursatsningar}

\section{1-2234-4 Samiskt samarbete}

\begin{tabular}{|l|c|c|c|c|c|} 
Valuta & Budget 14 & Budget 13 & Budget 12 & Disp./bud. 12 & Bud.disp. af \\
\hline DKK & 3.702 .000 & 3.644 .000 & 3.580 .000 & $97 \%$ & $\begin{array}{c}\text { Samerådet } \\
\text { och Samiska } \\
\text { konstnärsrådet }\end{array}$
\end{tabular}

Formål

Ändamålet med beviljningen är att stöda det samiska samarbetet på kulturområdet. Budgetposten fördelas mellan Samerådet och Samiska konstnärsrådet. Samerådet är de norska, finska, svenska och ryska samernas gemensamma kulturpolitiska och politiska organ, som idag är organiserat med huvudvikt på fyra sakområden: kultur, mänskliga rättigheter, miljöarbete och samarbete mellan urbefolkningar. Samiska konstnärsrådet är takorganisationen för samiska konstnärsorganisationer som har författare, bildkonstnärer, musiker, komponister och teateranställda som medlemmar.

Stödet är i huvudsak ämnat för kulturstöd men en mindre andel av stödet går till drift av verksamheten som de två aktörerna driver.

Prioriteringer i Samerådet och Samiska konstnärsrådet skall eftersträva 2014 att använda största delen av beviljningarna till kulturstöd och en mindre del till administrativa driftskostnader. Samerådet och Samiska konstnärsrådet skall i den verksamhet som beviljningen finansierar beakta strategin för det nordiska kultursamarbetet 2013-2020.

- Stöda, stimulera och utveckla de lokala samiska konstnärerna och kulturutövarna, bevarandet av det samiska kulturarvet och kulturlivets särart samt det samiska kulturlivet.

- Informera om samiska kulturfrågor och ansvara för urfolkens kultursamarbete.

- Utdela och/eller administrera kulturstöd till samiska konst- och kulturaktörer. 


\section{Fiskeri og havbrug, Jordbrug, Levnedsmidler og Skovbrug}

\section{Generel indledning}

Generelt

MR-FJLS består af ét ministerråd med fire politikområder: Fiskeri og havbrug, Jordbrug, Levnedsmidler og Skovbrug.

Ministerrådets embedsmandsstruktur består af én embedsmandskomité (EK-FJLS) med integrerede afdelinger, og består af fem selvstændige og samarbejdende enheder, nemlig en eksekutivkomité og fire afdelinger for henholdsvis fiskeri og havbrug, jordbrug, levnedsmidler og skovbrug.

MR-FJLS' kerneopgaver er at fremme bæredygtig udnyttelse af naturressourcer, inklusive de genetiske ressourcer. MR-FJLS bidrager til at sikre tillid og tilgang til gode madvarer, som en forudsætning for bedre sundhed hos nordiske borgere og udvikle de muligheder, som findes i nordiske råvarer og madkultur. Forskning og innovation indgår som en nødvendig forudsætning i dette arbejde.

Udmøntning af EK-FJLS (Eksekutiv) besluttede, at de samlede reduktiobesparelse i ner på 4,1\% (inkl. de administrative besparelser) vil rebudget 2014 sultere i en nedskæring af midlerne til programmet for $\mathrm{Ny}$ Nordisk Mad II på 680.000 DKK, institutionen NordGen på 400.000 SEK, svarende til 1,7\% nedskæring, og resten af budgetposterne med en pro rata reduktion med 3,7 $\%$. Den administrative besparelse på 259 TDKK udmøntes gennem tilpasninger under de forskellige budgetposter, som bliver reduceret.

Ministerrådets styringsdokumenter
Gældende styringsdokument for MR-FJLS er rammeprogrammet for 2013-2016, som blev godkendt af MR-FJLS den 28. juni 2012 og blev forelagt på Nordisk Råds session 2012.

Rammeprogrammet for MR-FJLS 2013-2016 har fokus på tre overordnede udfordringer 
- Konkurrencedygtig produktion

- Bæredygtig naturressourceforvaltning

- $\quad$ get velfærd

Formandsprogrammet for de enkelte år, der skal præcisere og supplere rammeprogrammet, udgør tilsammen handlingsprogrammet for samarbejdet. For 2014 har det islandske formandskab "Bioøkonomi" som sin prioritering. Derudover findes der forskellige programmer, der på hver sit felt understøtter målsætningerne i rammeprogrammet for MR-FJLS. MR-FJLS lægger vægt på løbende at udvikle samarbejdet om politiske og faglige problemstillinger i andre dele af det nordiske samarbejde og i Nordisk Ministerråd. Dels samarbejder sektorerne direkte eller gennem programmerne. Endvidere lægges vægt på at samarbejde med Nordisk Råd og i forhold til internationale institutioner arbejdes i relation til EU, FAO, OECD og Verdensbanken.

Et tættere samarbejde mellem SamNordisk Skovforskning (SNS), Nordisk Komite for jordbrugs- og madforskning (NKJ) og Arbejdsgruppe for fiskerisamarbejd (AG-Fisk) blev etableret i 2012 med det formål at drøfte og formulere ministerrådets forskningspolicy. Samtidig indgår disse også i løbende dialoger og samarbejder med NordForsk, NEF og Nordisk Innovation.

Resumé af Ministerrådets resultater i 2012
Formandsprogrammet for MR-FJLS relateredes til det overordnede norske formandskabsprogram og for FJLSområdet udtrykkedes det i de værdinormer, som gør Norden til foregangsregion som sikrer udviklingen af primærerhvervene i respekt for bæredygtighed, klima, miljø, ernæring og fødevaresikkerhed.

Resultaterne fra ministerrådets arbejde i 2012 disponeres i det følgende efter de indsatsområder, som fremgår af Rammeprogrammet 2009-2012 og stilles op mod områdets målsætning. 
Nordisk konkurrencekraft

- Konkurrencekraftig produktion gennem aktiviteter, som har sat fokus på erhvervets rammebetingelser.

- Udvikle mærknings- og certificeringssystemer, som tilfredsstiller forbrugernes behov.

- Seminar med fokus på grøn vækst i jordbrug og fiskeri.

- Seminar fokuserede på skovens rolle i forhold til, træbrug og arkitektur, naturmangfoldighed, klima og bioenergi.

Klima

- Fokus på primærerhvervene, dvs. hvad erhvervene kan iværksætte for at reducere klimaproblemerne.

- Skovbrugssamarbejdets opfølgning på Selfossdeklarationen om bæredygtigt skovbrug, som fokuserer på vandmiljø og klimaforandringer.

- En konference om bæredygtig produktion og udnyttelse af biomasse, som del af ministerrådets engagement i forhold til EU's Østersøstrategi. Dette forslag blev siden ført videre til EuropaKommissionen, og har efterfølgende ført til, at der i den nye aktions plan er indført en "Horizontal Action Sustainable Development and Bioeconomy" som NMRS har fået koordinerende ansvar for.

- Ministrenes "Nidarosdeklaration" om grøn vækst.

Kyst- og landsbyudvikling

- Samarbejdet har støttet bæredygtig udvikling af kyst og landsbyer i Norden.

- De fiskeripolitiske aktiviteter som har et klart kystudviklingsperspektiv.

- Ny Nordisk Mad II som satser på udnyttelse af lokale råvarer og lokal madkultur og tradition.

- Det norske formandskab gennemførte to seminarer, en om kystkultur og sjømat i Bergen og den anden om Skageraksamarbejdet om kystkultur i 


\section{Langesund.}

Velfærd, levnedsmidler og sundhed

- Sunt kosthold, sunne valg, matglede, god vannkvalitet og aktiv livsstil er viktig for enkeltindividet og for velferdsstatens utvikling.

- Et sunnere kosthold legger grunnlag for bedre helse og levekår

- Forbedret vannkvalitet gir bedre helse og velferd

- Oppnå målet om god dyrevelferd.

Internationalt samarbejde

- I forbindelse med FN konferencen Rio+20 "The Future We Want" gennemførtes et side-event med fokus på Ny Nordisk Mad og landdistriktsudvikling med titlen "From New Nordic Food to New Rural Economy".

I forhold til Østersøstrategien blev etableret netværk og samarbejdsrelationer inden for skovforskningen, arbejdet med genetiske ressourcer og veterinært beredskab.

\begin{tabular}{|c|c|c|c|c|c|}
\hline & \multirow{2}{*}{$\begin{array}{c}\text { Budget } \\
2014\end{array}$} & \multirow{2}{*}{$\begin{array}{l}\text { Budget } \\
2013\end{array}$} & \multicolumn{2}{|c|}{ Difference } \\
\hline & & & & $+/-$ & $\%$ \\
\hline \multicolumn{2}{|c|}{ Sum MR-FJLS (TDKK) } & 41.093 & 41.598 & -505 & $-1,2 \%$ \\
\hline & Projektmidler & 1.716 & 2.369 & -653 & $-27,6 \%$ \\
\hline \multirow[t]{2}{*}{$3-6420-2$} & Ny nordisk mad & 1.716 & 2.369 & -653 & $-27,6 \%$ \\
\hline & Fiskeri & 6.106 & 6.240 & -134 & $-2,1 \%$ \\
\hline \multirow{3}{*}{$3-6610-1$} & Projektmedel - Fiskeri & 6.106 & 6.240 & -134 & $-2,1 \%$ \\
\hline & Jord-och skovbrug & 27.761 & 27.358 & 403 & $1,5 \%$ \\
\hline & Projektmidler - jordbrug & 1.171 & 1.196 & -25 & $-2,1 \%$ \\
\hline $3-6510-1$ & Projektmidler Jordbrug & 364 & 372 & -8 & $-2,2 \%$ \\
\hline \multirow[t]{2}{*}{$3-6520-2$} & $\begin{array}{l}\text { Nordiskt kontaktorgan för jordbruksforsk- } \\
\text { ning (NKJ) }\end{array}$ & 807 & 824 & -17 & $-2,1 \%$ \\
\hline & Institutioner - jordbrug & 20.810 & 20.256 & 554 & $2,7 \%$ \\
\hline \multirow[t]{2}{*}{$3-6585-3$} & Nordisk Genressource Center (NordGen) & 20.810 & 20.256 & 554 & $2,7 \%$ \\
\hline & Projektmidler - skovbrug & 5.780 & 5.906 & -126 & $-2,1 \%$ \\
\hline $3-6310-1$ & Projektmidler Skovbrug & 301 & 307 & -6 & $-2,0 \%$ \\
\hline \multirow[t]{2}{*}{$3-6581-2$} & Samnordisk skogsforskning (SNS) & 5.479 & 5.599 & -120 & $-2,1 \%$ \\
\hline & Levnedsmidler & 5.510 & 5.631 & -121 & $-2,1 \%$ \\
\hline $3-6810-1$ & Projektmedel - Levnedsmidler & 4.971 & 5.080 & -109 & $-2,1 \%$ \\
\hline $3-6830-1$ & Nordisk handlingsplan for bedre helse og & 539 & 551 & -12 & $-2,2 \%$ \\
\hline
\end{tabular}




\begin{tabular}{crrrr}
\hline Opdelt på kategorier & $\mathbf{4 1 . 0 9 3}$ & $\mathbf{4 1 . 5 9 8}$ & $\mathbf{1 0 0} \%$ & $\mathbf{1 0 0 \%}$ \\
\hline Projektmidler & 12.281 & 12.550 & $29,9 \%$ & $30,2 \%$ \\
Programlignende aktiviteter & 8.002 & 8.792 & $19,5 \%$ & $21,1 \%$ \\
Institutioner & 20.810 & 20.256 & $50,6 \%$ & $48,7 \%$
\end{tabular}

$\underline{3-6420-2}$ Ny nordisk mad

\begin{tabular}{|l|c|c|c|c|c|} 
Valuta & Budget 14 & Budget 13 & Budget 12 & Disp./bud. 12 & Bud.disp. af \\
\hline DKK & 1.716 .000 & 2.369 .000 & 2.327 .000 & $100 \%$ & $\begin{array}{l}\text { Styregrup- } \\
\text { pen for Ny } \\
\text { Nordisk Mad }\end{array}$
\end{tabular}

Formål

Ny Nordisk Mad er en konkret værdiskabende og innovativ satsning. Arbejdet med Ny Nordisk Mad er forankret inden for MR-FJLS, men har et tværsektorielt sigte, og involverer et tæt samarbejde med KreaNord og det nordiske kultursamarbejde. Til programmet er etableret en programorganisation och arbetet leds av en styrgrupp.

Prioriteringer i Prioriteringer for programmet for 2014, fastlægges ultimo 2014 2013, men følger af rammeprogrammet for Ny Nordisk Mad II 2010-2014.

Ledelse og Planlagte udgifter 2013: 950.000 DKK adm.

Faktiske udgifter 2011: 900.000 DKK

\section{Fiskeri}

3-6610-1 Projektmidler - Fiskeri

\begin{tabular}{|l|c|c|c|c|c|} 
Valuta & Budget 14 & Budget 13 & Budget 12 & Disp./bud. 12 & Bud.disp. af \\
\hline DKK & 6.106 .000 & 6.240 .000 & 6.130 .000 & $97 \%$ & $\begin{array}{c}\text { EK-FJLS } \\
\text { (Fiskeri og } \\
\text { Havbrug) }\end{array}$
\end{tabular}

Formål

Formålet med midlerne er at understøtte politisk prioriterede aktiviteter, som fremmer bæredygtigt fiskeri og akvakultur samt fangst af marine pattedyr inden for rammerne af Rammeprogrammet for MR-FJLS samt for- 
Fiskeri og havbrug, Jordbrug, Levnedsmidler og Skovbrug

mandskabsprogrammet for hvert år.

Prioriteringer i Prioriteringerne i 2014 vil have deres udgangspunkt i

2014 målsætningerne i det nye Rammeprogram for MR-FJLS 2013-16 og det islandske formandskabsprogram vil være toneangivende for de aktuelle aktiviteter i fiskerisamarbejdet i 2014.

Det forventes, at de pågående større substanstemaer i fiskerisamarbejdet fortsættes i 2014:

- Fiskeriernes konkurrencekraft og rammebetingelser

- Udvikling af bæredygtig akvakultur

- Udvikling af samarbejde med internationale organer

- Kystsamfund, udvikling og kultur

- Særligt fokus på arktiske problemstillinger

- Klimaforandringenes påvirkning på hav og fiskeri

- Udnyttelse af marine pattedyr

- Udvikling af integreret havforvaltning

- Udvikling af økosystem- og flerartsforvaltning

- Udvikling af nordisk bioøkonomi og grøn vækst

Ledelse og Planlagte udgifter 2014: 250.000 DKK

adm. Faktiske udgifter 2012: 250.000 DKK

Sekretariats- Sekretariatsfunktionen i AG-Fisk varetages af DTUfunktion Aqua, Hirthals

\section{Jordbrug}

3-6510-1 Projektmidler - Jordbrug

\begin{tabular}{|l|c|c|c|c|c|} 
Valuta & Budget 14 & Budget 13 & Budget 12 & Disp./bud. 12 & Bud.disp. af \\
\hline DKK & 364.000 & 372.000 & 365.000 & $93 \%$ & $\begin{array}{c}\text { EK-FJLS } \\
\text { (Jordbrug) }\end{array}$
\end{tabular}

Formål

Jordbrugsafdelingens midler anvendes til at understøtte afdelingens aktiviteter i relation til at føre rammepro- 
grammets målsætninger ud i livet. Dette gøres primært ved at understøtte de policyrettede aktiviteter i regi af embedsmandskomitéen og gennemførelse af formandskabsprogrammet.

Prioriteringer i Prioriteringerne for 2014 følger rammeprogrammet for 2014

MR-FJLS og det islandske formandskabsprogram og der vil især komme fokus på bioøkonomien. Der vil gennem fokus på bioøkonomien blive prioriteret inden for følgende områder:

- Bioøkonomi og jordbrugets rolle

- Bioøkonomi og kyst- og landdistriktsudvikling

- Jordbrugets konkurrencekraft

- Miljø- og klimaspørgsmål i relation til jordbruget

- Genressourcespørgsmål

\section{3-6520-2 Kontaktorgan for jordbrugsforskning (NKJ)}

\begin{tabular}{|l|c|c|c|c|c|} 
Valuta & Budget 14 & Budget 13 & Budget 12 & Disp./bud. 12 & Bud.disp. af \\
\hline DKK & 807.000 & 824.000 & 809.000 & $100 \%$ & NKJ
\end{tabular}

Formål

Nordiska kommitteen för jordbruks- och matforskning (NKJ) har som övergripande mål att bidra till en kunskapsbaserad jordbruks- och matsektor i de nordiska länderna. Det görs genom att främja och stödja nordiskt forskningssamarbete i jordbruks- och matsektorn, inklusive skog och fisk. NKJs arbete ska tillföra ett mervärde till forskningen på nationell och europeisk nivå. NKJ ska bidra till nationell, nordisk och europeisk politikutformning inom sitt ansvarsområde och har en rådgivande funktion till Nordiska ministerrådet i forskningspolitiska frågor när det gäller jordbruks- och matforskning.

Prioriteringer i NKJs fortsätter sitt strategiska arbete i linje med strategin 2014 för 2011-2014. Störst fokus ligger på arbete under temat ett "bio-baserat" samhälle, där NKJ har arbetat fram ett strategidokument, Nordiska Bioekonomi-Initiativet (NBI), som ligger till grund för det fortsatta arbetet. NKJ kommer också prioritera projektet Arctic Bioeconomy, 
som ska kartlägga de förnybara biologiska resurserna i Arktis. Representanter för NKJ kommer också att delta i olika aktiviteter på den europeiska forskningsarenan.

Ledelse og adm.

Sekretariatsfunktion
Planerade utgifter för 2014: 500000 NOK (nationalt finansieret)

Faktiska utgifter 2012: 500000 NOK (nationalt finansieret)

Sekretariatet finansieras genom nationella medlemsavgifter. Bidraget på från NMR används till strategiska policyrelaterade aktiviteter. NKJs sekretariat ligger hos NordForsk i Oslo.

\section{3-6585-3 Nordisk Genressource Center (NordGen)}

\begin{tabular}{|l|c|c|c|c|c|} 
Valuta & Budget 14 & Budget 13 & Budget 12 & NMR fin. 12 & Bud.disp. af \\
\hline SEK & 23.920 .000 & 24.114 .000 & 23.887 .000 & $75 \%$ & NordGen \\
\hline $\begin{array}{l}\text { Modsv. } \\
\text { DKK }\end{array}$ & 20.810 .000 & 20.256 .000 & 19.587 .000 & & \\
\hline
\end{tabular}

Formål

NordGen skal fremme fælles forvaltning af genetiske ressourcer i Norden og på den måde bidrage til fødevaresikkerhed og erhvervsudviklingen. NordGen skal videre påvirke Norden og det internationale samfund til bæredygtige, retfærdige og transparente løsninger for brug og bevaring af genetiske ressourcer.

Prioriteringer i Ved indgangen til 2012 indledtes en ny kontraktperiode 2014 mellem Nordisk Ministerråd og NordGen, denne løber til 31. december 2014. I 2011 besluttedes en samlet plan for NordGens økonomi, som fik tilslutning fra både MRFJLS og MR-SAM. Som følge af denne plan gennemførtes visse tilpasninger i organisationen med udgangspunkt $\mathrm{i}$ institutionens to kerneaktiviteter, som også udgjorde grundlaget for den nye kontrakt. Udover de organisatoriske tilpasninger, blev der også truffet beslutning om øgning af NordGens budget fra og med 2012, med henblik på at sikre institutionens evne til fortsat at kunne levere 
sine kerneydelser om bevaring og bæredygtig udnyttelse af genetiske ressorucer.

Efter gældende kontrakt mellem NMRS og NordGen er prioriteterne for institutionen i perioden 2012-2014 fastlagt. NordGens to kerneopgaver er at sikre bevaring af genetiske ressourcer relevant for mad og landbrug og at bidrage til bæredygtig udnyttelse af genetiske ressourcer relevant for mad og landbrug.

Kontrakt- 2102-2014

periode

Kontrakt- Opfyldt.

status

Økonomi NordGen følger banen med den langsigtede økonomiske udvikling.

Ledelse og Planlagte udgifter (2014): 5.331.000 DKK

adm.

Faktiske udgifter (2012): 3.821.000 DKK

\section{Skovbrug}

3-6310-1 Projektmidler - Skovbrug

\begin{tabular}{|l|c|c|c|c|c|} 
Valuta & Budget 14 & Budget 13 & Budget 12 & Disp./bud. 12 & Bud.disp. af \\
\hline DKK & 301.000 & 307.000 & 389.000 & $71 \%$ & $\begin{array}{c}\text { EK-FJLS } \\
\text { (Skovbrug) }\end{array}$
\end{tabular}

Formål Skovbrugsafdelingens projektmidler anvendes til at understøtte afdelingens aktiviteter i relation til at føre rammeprogrammets målsætninger ud i livet. Dette gøres primært ved at understøtte de policyrettede aktiviteter i regi af embedsmandskomitéen og gennemførelse af formandskabsprogrammet.

Prioriteringer i Prioriteringerne for 2014 følger rammeprogrammet for 2014

MR-FJLS og det islandske formandskabsprogram. Der vil gennem fokus på bioøkonomi blive prioriteret inden for 
Fiskeri og havbrug, Jordbrug, Levnedsmidler og Skovbrug

følgende områder:

- Bioøkonomi og skovbrugets rolle

- Bioøkonomi og kyst- og landdistriktsudvikling

- Skovbrugets konkurrencekraft

- Skov og energi

- Skov og klima

- Skov og vand

3-6581-2 Samnordisk skogsforskning (SNS)

\begin{tabular}{|l|c|c|c|c|c|} 
Valuta & Budget 14 & Budget 13 & Budget 12 & Disp./bud. 12 & Bud.disp. af \\
\hline DKK & 5.479 .000 & 5.599 .000 & 5.413 .000 & $100 \%$ & SNS
\end{tabular}

Formål

SNS arbetar för att skapa nordisk synergi inom skogsforskningen genom att aktivt initiera nya samarbetsområden och fungera som ett dynamiskt, övergripande organ som samarbetar med de nationella forskningsaktörerna och skogssektorn i övrigt. Genom stöd till avancerade samnordiska forskningsnätverk och -projekt, vetenskapligt kunskapsutbyte och -förmedling samt forskarutbildning inom skogssektorn vill SNS medverka till att utveckla framtidens socialt, ekologiskt och ekonomiskt ansvarsfulla skogsbruk och nyttjande av träråvara i Norden.

Prioriteringer i Strategien for SNS for perioden 2014-17 forventes god2014 kendt inden årets udgang 2013, og prioriteringerne for 2014 vil derfor blive fastlagt på baggrund af den nye strategi.

Ledelse og Planlagte udgifter 2014: 850.000 DKK adm. Faktiske udgifter 2012: 707.000 DKK

Sekretariats- $\quad$ Sekretariatet for SNS bliver i perioden 2014-2017 forvenfunktion tet placeret ved SLU, Alnarp i Sverige 


\section{Levnedsmidler}

\section{3-6810-1 Projektmidler - levnedsmidler}

\begin{tabular}{|l|c|c|c|c|c|} 
Valuta & Budget 14 & Budget 13 & Budget 12 & Disp./bud. 12 & Bud.disp. af \\
\hline DKK & 4.971 .000 & 5.080 .000 & 3.877 .000 & $93 \%$ & $\begin{array}{c}\text { EK-FJLS } \\
\text { (Levneds- } \\
\text { midler) }\end{array}$
\end{tabular}

Formål

Fra 2013 er 6810 og 6820 sammenlagt til en samlet budgetpost. Deraf den store forskel i beløbene i forhold til budget 2012 .

Formålet med midlerne er at understøtte aktiviteter i forhold til sikre og sunde fødevarer, forbrugerbeskyttelse, og at arbejde for et højt niveau indenfor dyresundhed og dyrevelfærd. Dette gøres konkret i regi af levnedsmiddelsektorens arbejdsgrupper. Endvidere bruges midlerne til at understøtte de mere policy rettede aktiviteter i regi af embedsmandskomitéen og gennemførelse af formandskabsprogrammet.

Prioriteringer i Prioriteringerne for 2014 følger punkterne i det nye ram2014 meprogram for MR-FJLS 2013-16 samt det islandske formandskabsprogram. Der vil blive prioriteret inden for følgende områder:

- Konkurransedyktig produksjon

- Videreutvikle arbeid med mattrygghet (Food safety).

- Utvikle metoder for ensretting av et risikobasert tilsyn.

- Videreutvikle arbeid med redelig håndtering og omsetning samt korrekt informasjon til brukerne slik at disse kan ta informerte valg.

- Videreutvikle den nordiske tradisjonen med fokus på friske dyr som oppdrettes på en etisk forsvarlig måte.

- Arbeide for at satsing på "ny nordisk mat" ivaretar hensynene til mattrygghet, matkvalitet og kosthold. 
Fiskeri og havbrug, Jordbrug, Levnedsmidler og Skovbrug

- Bæredyktig ressursforvaltning

- Arbeid med å minske matsvinn i hele kjeden, uten å gi avkall på redelig og mattrygghet (Food safety).

- Vurdere konsekvensen av klimaendringer for næringsmiddeltrygghet herunder tilgang til rent drikkevann.

- Å opprettholde og videreutvikle de nordiske velferdssamfunnene.

- Styrke og videreutvikle arbeidet med å minimere risiko for helseskade (human og dyrehelse) på EK-FJLS (Livsmedel)s ansvarsområder.

- Fokus på risiko-nytte aspektet

- Styrke arbeidet med informasjon om helsefremmende kosthold og betydningen av fysisk aktivitet

- Implementere de nordiske næringsrekommendasjonene og omsette disse til anbefalinger for sammensetning av kosten, samt arbeide for å underlette forbrukernes muligheter for å ta helsemessige gunstige valg.

- Styrke arbeidet med å reversere den økende antimikrobielle resistens hos mennesker og dyr.

Ledelse og Planlagte udgifter 2014: 1.490.000 DKK

adm.

Faktiske udgifter 2012: 1.490.000 DKK

Sekretariats- Sekretariatsfunktionen i den nordiske arbejdsgruppe for funktion ernæring, mad og toksikologi (NKMT) varetages af Fødevarestyrelsen, Danmark.

Sekretariatsfunktionen i den nordiske arbejdsgruppe for madforvaltning og forbrugerinformation (NMF) varetages af Livsmedelsverket, Sverige.

Sekretariatsfunktionen i den nordiske arbejdsgruppe for mikrobiologi og dyresundhed/dyrevelfærd (NMDD) varetages af Mattillsynet, Norge. Generalsekretariatet i Nordisk Metodikkomite for Levnedsmidler (NMKL) varetages af Veterinærinstituttet, Norge. 
3-6820-1 Forskning - levnedsmidler

\begin{tabular}{|l|c|c|c|c|c|} 
Valuta & Budget 14 & Budget 13 & Budget 12 & Disp./bud. 12 & Bud.disp. af \\
\hline DKK & 0 & 0 & 1.113 .000 & $100 \%$ & $\begin{array}{c}\text { EK-FJLS } \\
\text { (Levneds- } \\
\text { midler) }\end{array}$
\end{tabular}

Budgetposten er nedlagt.

3-6830-1 Nordisk handlingsplan for bedre helse og livskvalitet

\begin{tabular}{|l|c|c|c|c|c|} 
Valuta & Budget 14 & Budget 13 & Budget 12 & Disp./bud. 12 & Bud.disp. af \\
\hline DKK & 539.000 & 551.000 & 541.000 & $97 \%$ & $\begin{array}{c}\text { EK-FJLS } \\
\text { (Levneds- } \\
\text { midler) }\end{array}$
\end{tabular}

Formål Formålet er at implementere den nordiske handlingsplan for bedre sundhed og livskvalitet gennem kost og fysisk aktivitet som en prioriteret indsats af tværsektoriel karakter.

Prioriteringer i Tværsektorielle aktiviteter indenfor handlingsplanens 2014 prioriteringsområder, som involverer flere fagsektorer. Opfølgning på de nordiske næringsstofanbefalinger vil være et prioriteret område, bl.a. med fokus på indtaget af salt og D-vitamin. 


\section{Jämställdhet}

\section{Generel indledning}

Generelt Det formella nordiska samarbetet inom Ministerrådet for jämställdhet (MR-JÄM) inleddes 1980. Samarbetet baserar sig på samarbetsprogrammet Jämställdhet skapar ett hållbart samhälle - Nordiskt jämställdhetspolitiskt samarbete 2011-2014. I utarbetandet av programmet har ministerrådet involverat och förankrat innehållet hos ett brett spektrum av aktörer i det civila samhället och politiska myndigheter i Norden, de baltiska länderna och Nordvästra Ryssland.

MR-JÄM har allt sedan etableringen arbetat aktivt för att utveckla och främja jämställdhet och jämlikhet i de nordiska samhällena. I det nordiska sammanhanget innebär det att omsorg, makt och inflytande fördelas lika mellan alla kvinnor/flickor och män/pojkar och allas rätt till lika rättigheter, skyldigheter och möjligheter inom alla samhällsområden och i alla livsfaser. Ett jämställt samhälle förutsätter ett samhäller fritt fån alla typer av könsrelaterat våld och annan ojämlik behandling. Mäns och pojkars aktiva deltagande i jämställdhetsarbetet är en förutsättning för att lyckas nå målet om ett verkligt jämställt samhälle präglat av mångfald.

Genom att jämställa alla mäns/pojkars och kvinnors/ flickors erfarenheter, kunskaper, kompetens och perspektiv säkra man både ett hållbart samhälle och uppnår ett bättre och mer rättvist samhälle. Genom jämställdhet säkerställer man $\mathrm{i}$ högre grad att alla tillgängliga mänskliga resurser i samhället tas tillvara, vilket ökar fortsättningarna för ekonomisk tillväxt och säkrar välfärden.

Det nordiska jämställdhetssamarbetet bygger på en gemensam demokratisk tradition och historia. Samarbetet har varit och är fortfarande till ömsesidig nytta för de nordiska länderna, de självstyrande områdena och närområ- 
dena. Det är viktigt att de relativt små nordiska välfärdssamhällena utbyter erfarenheter, använder sig av varandras kunskaper och för politiska debatter för att utveckla innehållet $\mathrm{i}$ och förståelsen av vad jämställdhet, jämlikhet och mångfald är.

Norden är en del av en allt mer globaliserad värld. Att delta $\mathrm{i}$ en globaliserad värld innebär att man från nordisk sida bör uppvisa ett internationellt engagemang. Jämställdhet är en del av den nordiska identiteten och har varit grundläggande för våra demokratier och utvecklandet av våra välfärdssamhällen. Visionen för jämställdhetsarbetet i nordiska ministerrådet är att vara en förebild för andra och på internationell nivå synliggöra hur vi i Norden möter globaliseringens utmaningar just genom att genomföra en jämställdhetspolitik som säkrar hållbara samhällen också i framtiden.

Samarbetet omfattar tre geografiska områden: de nordiska länderna och självstyrande områdena, de baltiska länderna, samt Nordvästra Ryssland. Vart och ett av de tre områdena har egna prioriterade teman. Jämställdhetsintegrering och mäns/pojkars aktiva deltagande ska ingå i samarbetsprogrammets alla områden som ett tvärgående tema. Nedan anges prioriteringarna för dessa tre nämnda områden.

Norden:

1) Jämställdhet på arbetsmarknaden

2) Jämställdhet inom utbildning

3) Kön, etnicitet och jämställdhet

4) Nolltolerans mot könsrelaterat våld

Samarbetet med de baltiska länderna:

1) Jämställdhet på arbetsmarknaden

2) Jämställdhetsundervisning

3) Jämställdhet/likabehandling i det offentliga rummet och i media

4) Nolltolerans mot könsrelaterat våld 
Nordvästra Ryssland:

1) Jämställdhetsundervisning

2) Nolltolerans mot könsrelaterat våld

Udmøntning af Jämställdhetssektorn har att företa en 3,7 \% besparing på besparelse i budget 2014 sin budget om 9.118.000 DKK (2013 priser). Den totala besparingen motsvarar 339.000 DKK varav 20.000 DKK utgör den administrativa besparingen på sektorn. Hela besparingen företas på budgetposten Projektmedel.

Ministerrådets styringsdokumenter

Det nordiska jämställdhetssamarbetet styrs av det fyraåriga samarbetsprogrammet Jämställdhet skapar ett hållbart samhälle - Nordiskt jämställdhetspolitiskt samarbete 2011-2014. Programmet realiseras genom årliga sektorprogram, som fastställer sektorns årliga prioriteringar och aktiviteter i förhållande till samarbetsprogrammet liksom gällande ordförandeskapsprogram. Därtill följer MR-JÄM alla de riktlinjer och överordnande styrningsdokument som har utarbetats för det nordiska samarbetet.

Det nordisk-baltiska jämställdhetssamarbetet fastställs på årliga NB8 möten på tjänstemannanivå, och NB8ministermöten som arrangeras vid behov. Det nordiskbaltiska jämställdhetssamarbetet följer även Retningslinjer for Nordisk Ministerråds samarbeid med Estland, Latvia og Litauen 2009-2013.

Det nordiska jämställdhetssamarbetet med Nordvästra Ryssland tar utgångspunkt i Protocol of Intent between the Nordic Council of Ministers and the Government of St Petersburg of the Russian Federation och Guidelines for the Nordic Council of Ministers' co-operation with NorthWest Russia 2009-2013.

Ytterligare ett styrningsdokument med stor relevans för jämställdhetssektorn är nordiska ministerrådet strategi för hållbar utveckling - Ett gott liv i ett hållbart Norden. Därtill använder jämställdhetssektorn så kallade "trojka"möten. Dessa möten innebär att innevarande, föregående och kommande ordförandeskapet möts. Syftet med dessa möten är att garantera kontinuitet och sammanhang mel- 
Resumé af Ministerrådets resultater i 2012 lan det nordiska jämställdhetssamarbetets årliga sektorprogram och samarbetsprogram.

År 2012 var det andra året för genomförandet av samarbetsprogrammet Jämställdhet skapar ett hållbart samhälle. Sektorprogrammet år 2012 fokuserade på samarbetsprogrammets två tvärgående teman: integrering av ett könsoch jämställdhetsperspektiv samt aktivt deltagande av män/pojkar.

Exempel på större konferenser och seminarier:

Mansforskningskonferensen Maskuliniteter i förändring män, jämställdhet och livskvalitet.

Seminarium på temat Män och rekrytering till omsorgsyrken (inspirerat av det danska ordförandeskapets arbete 2010 - Skift job - ikke køn (www.skiftjob.dk).

Expertseminarium ("dialogmöte") om Män, anti-feminism och främlingsfientlighet.

Samisk jämställdhetskonferens.

Exempel på köns- och jämställdhetsintegreringsinsatser: Projekt om könsbalans i Nordisk forskning i samarbete med Ministerrådet för utbildning (MR-U).

Planläggning och beslut om utbildningsinsats för att re vitaliering av NMR:s jämställdhets-integreringsarbete (implementeras under 2013).

Internationella aktiviteter:

Årligt deltagande vid FN-sessionen Committee on the Status of Women (CSW), detta år i form av ett ministerseminarium under rubriken "Equality between Women and Men - the Nordic Way" samt ett expertseminarium på temat "Rural women - an economic potential". Som en fortsättning på tidigare arbete med kön, klimat och hållbar utveckling arrangerades seminariet "Gender Equality is Sustainability" inom ramen för Nordiska ministerrådets satsning "The Nordic Way at Rio+20". Samarbetet med de baltiska länderna och NV Ryssland Inom ramen för samarbetet med de baltiska länderna genomfördes lanseringen av den danska barnboken "Den 
dag då Rikke var Rasmus - Den dag då Frederik var Frida" med tillhörande lärarvägledning. Ett rundabordssamal - Nordic Baltic Round Table Meeting on Gender and Media - genomfördes även i förbindelse med det årliga NB8-mötet på tjänstemannanivå.

Inom ramen för samarbetet med NV Ryssland har inte någon ny aktivitet genomförts under 2012 men planläggning för aktiviteter 2013 påbörjats.

\section{NORDISK INFORMATION FÖR KUNSKAP OM KöN (NIKK)}

Nationella sekretariatet för genusforskning vid Göteborgs universitet valdes under 2012 till förvaltningsorgan för det nyetablerade samarbetsorganet Nordisk Information för kunskap om kön (NIKK). Uppstartsverksamheten påbörjades oktober 2012. Uppstartarbetet har bestått $\mathrm{i}$ inventering och upprättandet av web portal samt rekrytering av personal.

\begin{tabular}{|c|c|c|c|c|c|}
\hline & \multirow{2}{*}{$\begin{array}{c}\text { Budget } \\
2014\end{array}$} & \multirow{2}{*}{$\begin{array}{c}\text { Budget } \\
2013\end{array}$} & \multicolumn{2}{|c|}{ Difference } \\
\hline & & & & $+/-$ & $\%$ \\
\hline MR-Jäm & TDKK) & 8.919 & 9.118 & -199 & $-2,2 \%$ \\
\hline & Projektmedel & 8.919 & 9.118 & -199 & $-2,2 \%$ \\
\hline $1-4410-1$ & Projektmedel - Jämställdhet & 6.379 & 6.064 & 315 & $5,2 \%$ \\
\hline $1-4480-2$ & $\begin{array}{l}\text { Nordisk information för kunskap om kön } \\
\text { (NIKK) }\end{array}$ & 2.540 & 3.054 & -514 & $-16,8 \%$ \\
\hline \multicolumn{2}{|c|}{ Opdelt på kategorier } & 8.919 & 9.118 & $100 \%$ & $100 \%$ \\
\hline & Projektmidler & 6.379 & 6.064 & $71,5 \%$ & $66,5 \%$ \\
\hline & Programlignende aktiviteter & 2.540 & 3.054 & $28,5 \%$ & $33,5 \%$ \\
\hline
\end{tabular}

*I tillägg till den 2,5 MDKK årliga beviljning i 2013, innehöll budgetposten en engångsbeviljning om 0,5 MDKK för eventuella uppstartskostnader. Detta förklarar ändring på beviljningen mellan åren. 
1-4410-1 Projektmedel - Jämställdhet

\begin{tabular}{|l|c|c|c|c|c|} 
Valuta & Budget 14 & Budget 13 & Budget 12 & Disp./bud. 12 & Bud.disp. af \\
\hline DKK & 6.379 .000 & 6.064 .000 & 3.657 .000 & $87 \%$ & MR/Äk-JÄM
\end{tabular}

Formål

Medlen ska användas till att följa upp de behov, intressen och önskemål som MR-JÄM beslutar om för att inom ramen av det nordiska jämställdhetssamarbetet genomföras i de fem nordiska länderna, Färöarna, Grönland och Åland och i Nordens närområden samt på internationell arena. Medlen fördelas enligt en modell där 3.0 MDKK avsätts till genomförandet av det årliga sektorprogrammet och 2.8 MDKK avsätt till en ansökningspott administrerad av NIKK. Av reseterande medel avsätts 229.000 DKK till Ad hoc initiativ (politiska prioriteringar) och 250.000 DKK till sektorns administrativa omkostnader.

Prioriteringer i Under 2014 kommer MR-JÄM att lägga vikt vid att ut2014 veckla aktiviteter inom ramen för samarbetsprogrammet Jämställdhet skapar ett hållbart samhälle - Nordiskt jämställdhetspolitiskt samarbete 2011-2014.

Aktiviteterna på det nordiska jämställdhetspolitiska området under år 2014 kommer att stöda det isländska ordförandeskapets prioriteringar i Nordiska ministerrådet. Utöver nya aktiviteter kommer det isländska ordförandeskapet under 2014 att föra vidare och ytterligare utveckla enskilda aktiviteter, som startades under 2011 och 2012, exempelvis projektet Deltid, kön och ekonomisk fördelning i Norden samt "Nordic Project on Gender Mainstreaming - best practices and effects". Därtill kommer sektorn att arbeta med utformandet av ett nytt samarbetsprogram som ska träda i kraft 2015. 
1-4480-2 Nordisk information för kunskap om kön (NIKK)

\begin{tabular}{|l|c|c|c|c|c|} 
Valuta & Budget 14 & Budget 13 & Budget 12 & Disp./bud. 12 & Bud.disp. af \\
\hline DKK & 2.540 .000 & 3.054 .000 & 5.300 .000 & $100 \%$ & MR/Äk-JÄM
\end{tabular}

Formål

Nordisk Information för Kunskap om Kön (NIKK) skall vara ett synliggörande och förmedlande organ samt ett flexibelt och operationellt verktyg som stöder realiseringen av nordiska jämställdhetspolitiska prioriteringar. NIKK skall insamla, använda och förmedla nationell forskning, politik och praxis i ett nordiskt perspektiv och till en bred målgrupp. Vidare skall NIKK koordinera utförande och förmedling av komparativa studier och projekt efter beställning av ÄK-JÄM. I relation till sektorprogrammet skall NIKK kunna agera projektsekretariat.

I tillägg till den 2,5 MDKK årliga beviljning i 2013, innehöll budgetposten en engångsbeviljning om 0,5 MDKK för eventuella uppstartskostnader. Detta förklarar ändring på beviljningen mellan åren.

Prioriteringer i NIKK:s huvuduppgift och främsta prioritering är att syn2014 liggöra och förmedla vad som händer tvärsektoriellt och på jämställdhetsområdet i hela Norden, såväl inom forskning som inom politik. På uppdrag av MR/ÄK-JÄM ska NIKK även vid behov bistå med att koordinera nordiska projekt. Sedan 2012 koordinerar NIKK, på uppdrag av ÄK-JÄM, projektet Deltid, kön och ekonomisk fördelning. Projektet avslutas under 2014.

Ledelse og adm.

Sekretariatsfunktion
Planlagda utgifter 2014: 2.500.000 DKK

Faktiska utgifter 2012: 645.023 DKK

Bemärkning: NIKK påbörjade sitt uppdrag oktober 2012 och var därmed verksam tre månader under 2012.

Sekretariatet för NIKK är placerat hos Nationella sekretariatet för genusforskning vid Göteborgs universitet. 


\section{Uddannelse og forskning}

\section{Generel indledning}

Generelt Nordisk Ministerråd for Uddannelse og Forskning (MRU) har ansvar for Nordisk Ministerråds samarbejde inden for områderne uddannelsespolitik og forskningspolitik, ligesom MR-U koordinerer ministerrådets samarbejde inden for områderne IT-politik og sprogpolitik. Udover dispositionsmidlerne har budgetrammen fire hovedkategorier: Politikudvikling, mobilitets-, projekt- og netværksprogrammet Nordplus, NordForsk og forskning i øvrigt (samarbejdsorganer).

En hovedprioritet for MR-U i 2014 er programmet Holdbar Nordisk Velfaerd, som MR-U gennemfører i samarbejde med MR-S under prioriteringsbudgettet. Inden for rammen af Holdbar Nordisk Velfærd arbejdes der for innovative løsninger, som kan udvikle og forny den nordiske velfærdsmodel. Løsningerne skal bidrage til øget kvalitet og ligestilling i uddannelse, arbejde samt helse og omsorg (se budgetpost 7-8210-2). Initiativer i relation til statsministrenes satsning på grøn vækst formuleret i pressemeddelelsen Norden - ledende i grøn voekst er en anden vigtig prioritet. MR-U har ansvaret for at udvikle samarbejdet om uddannelse og forskning for grøn vækst og bidrager til udvikling af en række andre områder knyttet til grøn vækst (se budgetpost 7-8111-2).

Rapporten om gennemgangen af det nordiske forskningssamarbejde Vilja till forskning? danner grundlaget for MR-U's arbejde med at udvikle et mere effektivt, fokuseret og sektorovergribende samarbejde på forskningsområdet. I 2014 vil spørgsmål som udvikling af fælles forskningsinfrastruktur have høj prioritet.

Politikudvikling

MR-U rådgives af ad hoc-arbejdsgrupper på prioriterede områder, Ekspertgruppen Nordens Sprogråd, det uformel- 
le forum af IT-direktører og Nordisk Netværk for Voksnes Læring (NVL).

Mobilitet-, projekt- og netværksprogrammet Nordplus I 2014 vil styrket information om og profilering af Nordplus samt spredning af resultater blive prioriteret.

NordForsk

NordForsk har en nøglefunktion i at implementere det nordiske forsknings- og innovationsområde (NORIA).

NordForsk er aktiv i at etablere samnordiske forskningsmiljøer samt forskeruddannelser af højeste internationale kvalitet. Disse baseres på nationale forskningsprioriteringer og styrker regionens konkurrenceevne og status som videnssamfund. NordForsk skal særskilt koncentrere sin indsats, hvor landene har en international stærk position eller et særskilt strategisk motiv. Initiativerne skal udformes ud fra nationale prioriteringer, og de organisationer, som finansierer den nationale forskning, skal stå for hovedparten af udgifterne, mens NordForsk bidrager med støtte til de samlede projekt- og programudgifter.

Eventuelle nye satsninger i 2014 er inden for områder som grøn vækst, Arktis samt nordiske sprog og nordisk sprogkultur.

Samarbejdsorganer

Samarbejdsorganerne er tidligere nordiske forskningsinstitutter, som er overført til nationalt niveau og er tilpasset værtslandets retslige forhold. Samarbejdsorganerne fremmer forskning og forskningssamarbejde inden for udvalgte specifikke fagområder. I 2014 vil MR-U understøtte den fortsatte nationalisering af samarbejdsorganerne.

Øvrige satsninger

MR-U vil i 2014 fortsætte sit samarbejde om arbejdsdeling og koncentration inden for højere uddannelse, ligesom diskussioner om finansiering, indhold og administration af Nordisk Master Program (NMP) fra 2015 vil præge året. 
I 2014 vil der på sprogområdet primært blive arbejdet med revisionen af den nordiske sprogkonvention og implementering af den nye organisering af sprogområdet.

For at forbedre regionens muligheder for at drage nytte af globaliseringen og udvikle uddannelsessystemerne videreføres samarbejdet med Estland, Letland og Litauen. Uddannelses- og forskningssamarbejdet med Rusland styrkes gennem samarbejdsaftalen med fælles finansiering og fælles prioriteringer. Arktisk samarbejde inden for uddannelse og forskning videreudvikles på basis af arbejdet $\mathrm{i}$ den såkaldte Arktis 8 ad hoc gruppe. Der skal endvidere følges op på områder, som styrker det nordiske samarbejde i forhold til EU, Europarådet mv.

Udmøntning af besparelse $\mathbf{i}$ budget 2014
Ministerrådets styringsdokumenter
Uddannelses- og forskningssektoren har i 2014 en budgetramme på i alt 233,870 MDKK (2013-tal). MR-U har i forhold til 2013 gennemført en besparelse på 3,8 pct., svarende til 9,201 MDKK. Besparelsen er udmøntet ved at reducere i dispositionsmidlerne, i budgetposten for ad hoc arbejdsgrupper på prioriterede områder og $\mathrm{i}$ budgetposten for Politikudvikling, Videnssamfund og IT-infrastruktur. Endvidere er der gennemført en besparelse på 20 pct. på de fem samarbejdsorganer Nordisk vulkanologisk institut (NORDVULK), Nordisk Institut for Asiastudier (NIAS), Nordisk Institut for Søret (NIfS), Nordisk Samisk Institut (NSU) samt Nordisk Institut for Teoretisk Fysik (Nordita). Hvad angår Nordisk Sommeruniversitet og Nordisk komité for Bioetik så skal de to faste programmer fra 2014 drives i regi af NordForsk.

Besparelsen på administration skal dels findes inden for bidragene til de fem samarbejdsorganer, dels ved at drive Nordisk Sommeruniversitet og Nordisk komité for Bioetik i regi af NordForsk. Midlerne til at drive de to virksomheder dækkes af NordForsks budget.

Det årlige formandskabsprogram og sektorprogrammet for uddannelse og forskning udgør centrale styringsdokumenter for sektoren. I 2013/2014 arbejder MR-U med at formulere et nyt strategi- og styringsdokument, som vil koble 
Resumé af Ministerrådets resultater i 2012 de strategiske satsninger med budgettet og de konkrete aktiviteter inden for sektoren.

- MR-U nedsatte i 2012 en arbejdsgruppe om samarbejdet under MR-U med henblik på at effektivisere og modernisere samarbejdet og beslutningsprocesser. Rapporten fra arbejdsgruppen peger blandt andet på et behov for at styrke betjeningen af ministrene i retning af et større politisk fokus. Dette kan for eksempel ske ved at kernevirksomhed defineres og prioriteres nærmere, at samarbejdet med andre ministerråd, embedsmandskomitéer og Nordisk Råd udvikles, og at EK-U rådgives af ad hoc-arbejdsgrupper på prioriterede områder frem for permanente arbejdsgrupper. I slutningen af 2012 nedsatte EK-U tre ad hoc-arbejdsgrupper: Ad hocarbejdsgruppen om samvirken, arbejdsdeling og koncentration (SAK) inden for højere uddannelse i Norden, Ad hoc-arbejdsgruppen på forsknigsområdet og Ad hoc-arbejdsgruppen om opdatering af eScience Action plan 2013.

- 2012 markerte begynnelsen på en ny 5-årig programperiode for Nordplus. Totalt 703 søknader ble mottatt våren 2012. Dette er en økning på nesten 100 søknader sammenlignet med 2010 og 2011. Det er imidlertid ofte flere søknader ved begynnelsen av en ny programperiode blant annet som følge av ekstra promotering av programmet. Totalt 396 prosjekt fikk innvilget støtte.

- I 2012 ble det gjennomført en evaluering av virksomheten på språkområdet under MR-U. Evalueringsprosessen har resultert $i$ en ny organisering av språkområdet fra 1. januar 2014. Det opprettes i løpet av 2013 en ad hoc-arbeidsgruppe for språkområdet med medlemmer utpekt av både EK-U og EK-K. Gruppens opgave blir at avklare hva et hovedansvar og et sektoransvar på språkområdet innebærer.

Det er i 2012 arbeidet videre med revisjonen av den nordiske språkkonvensjonen. 
- Inom globaliseringsprojektet Främjande av högre utbildning $i$ Norden finansierades under 2012 etableringen av universitetsbaserade nordiska nätverk vars måsättning är att knyta högre utbildning, forskning och innovation närmare samman, s.k. kunskapstriangelnätverk. Vidare genomfördes en utlysning för att stöjda utvecklingen av Sino-Nordiska kunskapstriangelnätverk, med deltagare både från nordiska universitet och från kinesiska universitet i Shanghaiområdet.

- Rådgivningsgruppen för det nordiska samarbetet inom högre utbildning (HÖGUT) har i 2012 fortsatt med globaliseringsprojektet Främjande av högre utbildning $i$ Norden. En utlysning av Nordiskt Master Program (NMP) har genomförts och en arbetskommitté för Nordiskt Master Program gav förslag till en långsiktig utveckling av programmet. HÖGUT har även finansierat projektet U-Map vars mål är att profilera styrkepositioner inom högre utbildning i Norden. Överenskommelsen om högre utbildning reviderades och förnyades under 2012 och en ny överenskommelse skrevs under av undervisningsministrarna för åren 2013-15. Rådgivningsgruppen lades ned den 31. december 2012.

- Rådgivningsgruppen for det nordiske skolesamarbeidet (NSS) har i 2012 prioritert arbeidet knyttet til frafall og kreativitet, innovation og entreprenørskap som en del av globaliseringsprosjektet En god opploering for ungdom og voksne. Nordens velferdssenter har fått i oppdrag å utvikle og lansere en nordisk ressursbank over program og tiltak som har oppnådd gode resultat for å stimulere 16-25-åringer å gjennomføre videregående opplæring eller komme inn på arbeidsmarkedet.

- NSS har i 2012 initert et arbeid med nordiske analyserapporter hvert annet år basert på de nordiske resultatene i internasjonale undersøkelser på skoleområdet. Med bakgrunn i resultatene fra The International Civic and Citizenship Education study 2009 (ICCS) om skoleele- 
vers kunnskap om samfunn og demokratisk deltakelse, er det igangsatt et samarbeid mellom forskere i Norden. Høsten 2012 ble konferansen Demokratiske verdier og laererbevissthet gjennomført for lærerutdannere i Norden. Målet var å bruke funn og erfaringer fra nordisk demokratiforskning til å stimulere undervisningen omkring demokratiperspektivet i lærerutdanningene.

Videre har NSS i fellesskap med SVL fortsatt arbeidet med nasjonal implementering av NQF/EQF, og gjennomført en temadiskussjon om fagopplæring og motivasjon. Rådgivningsgruppen ble nedlagt pr. 31. desember 2012 .

- Rådgivningsgruppen for det nordiske samarbejde om voksnes læring (SVL) har i 2012 i regi af globaliseringsprojektet En god uddannelse for unge og voksne iværksat en kortlægning af ligheder og forskelle i ordninger for voksne på ISCED 3-niveau (uddannelsesordninger for voksne efter grundskolen) i de nordiske lande og Færøerne, Grønland og Åland og færdiggjort en rapport om læse- og skriveundervisning for voksne. SVL har styrket samarbejdet med Arbejdsmarkedsudvalget under MR-A om et nordisk netværk for The Program for the International Assessment of Adult Competencies (PIAAC) frem mod offentliggørelse af resultaterne i efteråret 2013, gennemført en temadiskussion om fagoplæring og motivation samt en temadiskussion om integration og indvandrerlæreruddannelse. Rådgivningsgruppen blev nedlagt pr. 31. december 2012.

- NVL blev i 2011-2012 evalueret af Danmarks Evalueringsinstitut (EVA), se evalueringen på www.eva.dk. På baggrund af evalueringen har MR-U besluttet, at NVL skal fortsætte sit virke i perioden 2013-2016. Udførlig årsrapport for 2012 kan læses på NVL's hjemmeside på www.nordvux.net.

- Det uformelle forum af IT-direktører i Norden har i 2011 og 2012 drevet et fælles nordisk projekt om cloud 
computing. Arbejdet har resulteret i rapporten Nordic Public Sector Cloud Computing med forslag til nordisk samarbejde omkring cloud computing.

- Med afsæt i de nordisk statsministres beslutning om at satse på grøn vækst og bæredygtig udvikling har MR-U i 2012 arbejdet videre med at konkretisere uddannelsesog forskningsindsatsen i en handlingsplan for 20132015.

- MR-U har i 2012 iværksat et udviklingsarbejde for at øge børn, unge og voksnes kendskab til og viden om klimaforandringer og bæredygtig udvikling. Arbejdet skal lede frem til en opdateret, levende og attraktiv portal for læringsmateriale og skolesamarbejde om klima og bæredygtig udvikling på klimanorden.org.

- MR-U har i 2012 fortsat arbejdet med at udvikle og mobilisere strategiske forskningsprogrammer, der skal fremme bæredygtig udvikling og grøn vækst. Dette gøres først og fremmest gennem Topforskningsinitiativet (TFI) om klima, energi og miljø 2009-2013.

- Ministerrådet har under flera år arbetat för att förverkliga etableringen av The Baltic Ring, ett sammanhängande fiberoptiskt nätverk för avancerad datorkommunikation runt hela Östersjön. Initiativet Baltic Ring är etablerat som ett flaggskeppsprojekt $i$ handlingsplanen för EU:s Östersjöstrategi.

- Globaliseringsinitiativet eScience er et av de største nordiske forsknings- og utdanningsinitiativene og skal fremme nordisk samarbeid om å utvikle nye arbeidsformer og forskningsmetoder med basis i nødvendig elektronisk infrastruktur for å håndtere store mengder digitale data. De to satsingsområdene for programmet er forskning på klimaendringer og helse/sosiale forutsetninger for helse. 
- Programmet Education for Tomorrow har et budsjett på 75 MNOK, hvorav 4 MNOK er øremerket tematikken næring, læring og helse, og 2 MDKK er øremerket forskning om avhopp. Hensikten med programmet er å gi ny kunnskap slik at de nordiske utdanningssystemene er bedre rustet til å møte morgendagens behov.

- NordForsk har i 2012 begynt planleggingen av et initiativ innen samfunnssikkerhet som er en direkte oppfølger til Haga-ministrenes arbeid og som leverte en rapport som danner grunnlaget for ett nytt tematisk program. Dertil sonderes muligheten for å starte et tverrvitenskapelig program med fokus på Arktis. Se vidare NordForsk:s hemsida www.nordforsk.org.

- År 2012 skrev Nordiska ministerrådet och NordForsk en Memorandum of Understanding med EUkommissionen om att tillsammans med andra centrala intressenter i Europa arbeta för förverkligandet av ett europeiskt forskningsrum (ERA) år 2014.

- Nordiska ministerrådet har startat ett nordiskt-ryskt samarbete inom utbildning och forskning tillsammans med ryska utbildnings- och forskningsdepartementet.

\begin{tabular}{|c|c|c|c|c|c|}
\hline & \multirow{2}{*}{$\begin{array}{c}\text { Budget } \\
2014\end{array}$} & \multirow{2}{*}{$\begin{array}{c}\text { Budget } \\
2013\end{array}$} & \multicolumn{2}{|c|}{ Difference } \\
\hline & & & & $+/-$ & $\%$ \\
\hline \multicolumn{2}{|c|}{ MR-U (TDKK) } & 238.384 & 243.071 & -4.687 & $-1,9 \%$ \\
\hline & $\begin{array}{l}\text { Generelle utdannings- og forskningsinnsat- } \\
\text { ser }\end{array}$ & 2.939 & 4.896 & -1.957 & $-40,0 \%$ \\
\hline \multirow[t]{2}{*}{$2-2505-1$} & Dispositionsmedel-Utbildning och forskning & 2.939 & 4.896 & -1.957 & $-40,0 \%$ \\
\hline & Politikudvikling m.v. & 17.847 & 16.117 & 1.730 & $10,7 \%$ \\
\hline $2-2560-1$ & $\begin{array}{l}\text { Ad hoc arbejdsgrupper på prioriterede } \\
\text { områder }\end{array}$ & 2.595 & 3.054 & -459 & $-15,0 \%$ \\
\hline $2-2544-1$ & Det nordiske sprogsamarbejde & 6.911 & 5.453 & 1.458 & $26,7 \%$ \\
\hline $2-2553-1$ & $\begin{array}{l}\text { Politikudvikling, Videnssamfund og IT- } \\
\text { infrastruktur }\end{array}$ & 560 & 612 & -52 & $-8,5 \%$ \\
\hline \multirow[t]{2}{*}{$2-3127-2$} & Politikudvikling voksnes læring & 7.781 & 6.998 & 783 & $11,2 \%$ \\
\hline & Mobilitets og netvaerksprogrammer & 74.616 & 75.752 & -1.136 & $-1,5 \%$ \\
\hline $2-2513-2$ & Nordplus & 74.616 & 73.441 & 1.175 & $1,6 \%$ \\
\hline $2-2534-4$ & $\begin{array}{l}\text { Bidrag till Nordisk Sommaruniversitet } \\
\text { (NSU) }\end{array}$ & 0 & 1.212 & -1.212 & - \\
\hline
\end{tabular}




\begin{tabular}{llrrrr} 
& & $\begin{array}{c}\text { Budget } \\
\mathbf{2 0 1 4}\end{array}$ & $\begin{array}{r}\text { Budget } \\
\mathbf{2 0 1 3}\end{array}$ & \multicolumn{1}{c}{$\begin{array}{c}\text { Difference } \\
+/-\end{array}$} & \multicolumn{1}{c}{$\mathbf{\%}$} \\
\hline $2-2545-2$ & Samarbejdsnævnet for Nordenundervisning i & 0 & 1.099 & -1.099 & - \\
& udlandet & 121.382 & 119.731 & 1.651 & $1,4 \%$ \\
\hline NordForsk & 121.382 & 118.711 & 2.671 & $2,3 \%$ \\
\hline $2-3100-3$ & NordForsk & 0 & 1.020 & -1.020 & - \\
$2-3140-2$ & Nordisk komitè for Bioetikk & 21.600 & 26.575 & -4.975 & $-18,7 \%$ \\
& Forskning $i$ øvrigt & 8.869 & 10.911 & -2.042 & $-18,7 \%$ \\
\hline $2-3180-2$ & Nordisk Institut for Teoretisk Fysik (NOR- & & & \\
& DITA) & 2.643 & 3.251 & -608 & $-18,7 \%$ \\
$2-3181-2$ & Nordiska Institutet for Sjörett (NIfS) & 4.190 & 5.155 & -965 & $-18,7 \%$ \\
$2-3182-2$ & Nordisk Institutt for Asiastudier (NIAS) & 4.280 & 5.267 & -987 & $-18,7 \%$ \\
$2-3184-2$ & Nordisk vulkanologisk institut (NORD- & & & & \\
& VULK) & 1.618 & 1.991 & -373 & $-18,7 \%$ \\
$2-3185-2$ & Nordisk Samisk Institutt (NSI) & & & & \\
\hline & & $\mathbf{2 3 8 . 3 8 4}$ & $\mathbf{2 4 3 . 0 7 1}$ & $\mathbf{1 0 0 \%}$ & $\mathbf{1 0 0 \%}$ \\
\hline Opdelt på kategorier & 13.005 & 14.015 & $5,5 \%$ & $5,8 \%$ \\
\hline & Projektmidler & 103.997 & 109.133 & $43,6 \%$ & $44,9 \%$ \\
& Programlignende aktiviteter & 121.382 & 118.711 & $50,9 \%$ & $48,8 \%$ \\
& Institutioner & 0 & 1.212 & $0,0 \%$ & $0,5 \%$
\end{tabular}

\section{Generelle forsknings- og uddannelsesindsatser}

\section{2-2505-1 Dispositionsmidler - Uddannelse og forskning}

\begin{tabular}{|l|c|c|c|c|c|} 
Valuta & Budget 14 & Budget 13 & Budget 12 & Disp./bud. 12 & Bud.disp. af \\
\hline DKK & 2.939 .000 & 4.896 .000 & 3.592 .000 & $96 \%$ & EK-U
\end{tabular}

Formål

Dispositionsmidlerne anvendes til at finansiere politisk relevante projekter og initiativer, særligt med henblik på opfølgning af NMR's prioriteringsbudget og MR-U's strategiske satsninger.

Som led i den generelle besparelse på Nordisk Ministerråds budget i 2014 er der gennemført en besparelse på budgetposten på godt 1 MDKK. Desuden er der omdisponeret midler til to andre budgetposter, henholdsvis 250.000 DKK til budgetpost 2-2544-1 Det nordiske sprogsamarbejde, og 660.000 DKK til budgetpost 22553-1 Politikudvikling voksnes læring.

Under denne budgetpost er der reserveret 200.000 DKK 
til styrket information og kommunikation på sprogområdet.

\section{Politikudvikling}

2-2510-1 Rådgivningsgruppen for nordisk skolesamarbejde (NSS)

\begin{tabular}{|l|c|c|c|c|c|} 
Valuta & Budget 14 & Budget 13 & Budget 12 & Disp./bud. 12 & Bud.disp. af \\
\hline DKK & 0 & 0 & 1.651 .000 & $87 \%$ & NSS
\end{tabular}

Rådgivningsgruppen er nedlagt fra 2013.

2-2520-1 Rådgivningsgruppen for nordisk samarbejde om voksnes læring (SVL)

\begin{tabular}{|l|c|c|c|c|c|} 
Valuta & Budget 14 & Budget 13 & Budget 12 & Disp./bud. 12 & Bud.disp. af \\
\hline DKK & 0 & 0 & 1.175 .000 & $88 \%$ & SVL
\end{tabular}

Rådgivningsgruppen er nedlagt fra 2013.

2-2530-1 Rådgivningsgruppen for nordisk samarbejde indenfor højre uddannelse (HÖGUT)

\begin{tabular}{|l|c|c|c|c|c|} 
Valuta & Budget 14 & Budget 13 & Budget 12 & Disp./bud. 12 & Bud.disp. af \\
\hline DKK & 0 & 0 & 1.391 .000 & $80 \%$ & HÖGUT
\end{tabular}

Rådgivningsgruppen er nedlagt fra 2013.

2-2560-1 Ad hoc arbejdsgrupper på prioriterede områder

\begin{tabular}{|l|c|c|c|c|c|} 
Valuta & Budget 14 & Budget 13 & Budget 12 & Disp./bud. 12 & Bud.disp. af \\
\hline DKK & 2.595 .000 & 3.054 .000 & 0 & $0 \%$ & EK-U
\end{tabular}

106 
Formål

EK-U nedsatte i 2011 en arbejdsgruppe, der skulle vurdere om den måde, MR-U-systemet arbejder, er optimal, hvad angår målopnåelse, synergier, ressourceudnyttelse og indflydelse. Arbejdsgruppen foreslog blandt andet, at EK-U fremover anvender ad hoc arbejdsgrupper, tænketanke, nationale myndigheder og lignende til at frembringe indspil og underlag til ministerrådets arbejde på prioriterede områder. Ad hoc grupper forventes at kunne fungere som et effektivt og fleksibelt redskab for EK-U, herunder at kunne imødekomme behovet for tværsektorielt samarbejde om udvalgte temaer. I forlængelse heraf blev de de tre rådgivningsgrupper Rådgivningsgruppen for nordisk skolesamarbejde, NSS (budgetpost 2-25101), Rådgivningsgruppen for nordisk samarbejde om voksnes læring, SVL (2-2520-1) og Rådgivningsgruppen for nordisk samarbejde inden for højere uddannelse, HØGUT (2-2530-1) nedlagt pr. 31. december 2012.

Som led i den generelle besparelse på Nordisk Ministerråds budget i 2014 er der gennemført en besparelse på budgetposten på 500.000 DKK.

Prioriteringer i EK-U vil i 2014 fortsætte arbejde med at implementere 2014 brugen af ad hoc arbejdsgrupper på udvalgte områder.

2-2544-1 Det nordiske sprogsamarbejde

\begin{tabular}{|l|c|c|c|c|c|} 
Valuta & Budget 14 & Budget 13 & Budget 12 & Disp./bud. 12 & Bud.disp. af \\
\hline DKK & 6.911 .000 & 5.453 .000 & 5.357 .000 & $90 \%$ & ÄK-U
\end{tabular}

Formål

Språkområdet i det nordiske samarbeidet får en ny organisering fra 2014. Organiseringen er utformet på bakgrunn av en evaluering av enhetene på språkområdet under MR-U i 2012 og bygger på ønsket om å:

- Forenkle organiseringen av språkområdet

- Styrke koordineringen av aktiviteter 
- Ha klarere linjer for referanseforhold

- Styrke Nordisk Sprogkoordination

- Inndra kultursektoren.

Organiseringen av språkområdet ble besluttet av EK-U i 2012 og gjelder for perioden 1. januar 2014 - 31. desember 2018:

- MR-U beholder hovedansvaret for språkområdet $\mathrm{i}$ Nordisk Ministerråd

- MR-K beholder sektoransvaret for språkområdet i Nordisk Ministerråd

- EK-U er styregruppe for koordineringen av oppgaver og tjenesteytelser på språkområdet

- Det inngås en kontrakt med et forvaltningsorgan som ivaretar oppdraget å koordinere oppgaver og tjenesteytelser på språkområdet. De tjenesteytelser som forvaltningsorganet skal koordinere, er følgende:

o Program for språkkurs (Nordkurs, Nordspråk og De Nordiske Perler)

- Nordiske språkpiloter

- Nettverket for språknemndene i Norden

- Nordisk gruppe for parallellspråklighet (midlertidig gruppe)

- Sekretariatsbistand for Ekspertgruppen Nordens Språkråd (ENS).

Forvaltningsorganet forvalter de midler som er avsatt på språkområdet under MR-U. Midler til Nordplus Nordiske Språk-programmet forvaltes av administrator for programmet, og midler til Styrket informasjon og kommunikasjon på sprogområdet forvaltes av Nordisk ministerråds sekretariat.

Som led i beslutningen om organiseringen af sprogsamarbejdet fra 2014 er der tilført budgetposten 250.000 DKK fra budgetpost 2-2505-1 Dispositionsmidler - Uddannelse og forskning og 1.099.000 DKK fra budgetpost 2-2545-2 Samarbeidsnemnden for Nordenundervisning i utlandet til budgetposten. 
Prioriteringer i EK-U har besluttet følgende fokusområder for det nordis2014 ke språksamarbeidet fra 2014:

- De fire arbeidsområdene i 'Deklarasjon om nordisk språkpolitikk'. EK-U stadfestet i 2008 at ansvaret for oppfølgningen er nasjonalt. Nordiske tiltak skal understøtte nasjonale tiltak

- Innsatser for å styrke barn og unges språkforståelse av dansk, norsk og svensk. EK-U besluttet i 2008 et særlig fokus på barn og unges språkforståelse

- Lytteforståelse av dansk, norsk og svensk.

I 2014 vil det på språkområdet primært arbeides med:

- Revisjonen av den nordiske språkkonvensjonen i henhold til beslutning i NSK den 28. april 2011

- Implementeringen av den nye organiseringen av språkområdet.

Ledelse og adm.

Sekretariatsfunktion
Planlagte utgifter 2014: Språkområdet får en ny organisering fra 2014. EK-U beslutter forvaltningsorgan for oppdraget å koordinere oppgaver og tjenesteytelser i løpet av juni 2013. Kontrakt med forvaltningsorganet, herunder også administrasjonskostnader, forhandles i løpet av høsten 2013.

Faktiske utgifter 2012: 1) Dansk Sprognævn: 241.844 DKK. 2) Program for språkkurs: Nordkurs 150.000 DKK, Nordspråk: 61.000 DKK og De nordiske perler: 180.000 DKK. 3) De nordisk sprogpiloter: 10.000 DKK.

Foreningerne Nordens Forbund (FNF)

2-2553-1 Politikudvikling, Videnssamfund og IT-infrastruktur

\begin{tabular}{|l|c|c|c|c|c|} 
Valuta & Budget 14 & Budget 13 & Budget 12 & Disp./bud. 12 & Bud.disp. af \\
\hline DKK & 560.000 & 612.000 & 601.000 & $67 \%$ & ÄK-U
\end{tabular}


Formål

Det nordiske it-samarbejde er organiseret omkring et uformelt forum af IT-direktører fra hvert af de nordiske lande, som har ansvaret for at kvalificere, koordinere og videreudvikle NMRs IT-politik på områder, hvor der er synergi og nordisk nytte. Formålet er at bidrage til udviklingen af den digitale infrastruktur i Norden og udnytte fælles potentialer i offentlige it-investeringer. Budgetposten skal støtte MR-U's aktiviteter på ansvarsområdet.

Som led i den generelle besparelse på Nordisk Ministerråds budget i 2014 er der gennemført en besparelse på budgetposten på $61.200 \mathrm{DKK}$.

Prioriteringer i IT-samarbejdet vil fortsat prioritere arbejdet med at digi2014 talisere den offentlige sektor og bidrage udviklingen af den digitale infrastruktur i Norden, som grundlag for grøn vækst og bæredygtig velfærd i Norden. I 2014 vil indsatsen være koncentreret om følgende aktiviteter:

- Gennemførelse og formidling af et nordisk projekt om eSENS

- Videreudvikle eID og eSignature i Norden

- Strategi for it-samarbejdet.

\section{2-3127-2 Politikudvikling voksnes læring}

\begin{tabular}{|l|c|c|c|c|c|} 
Valuta & Budget 14 & Budget 13 & Budget 12 & Disp./bud. 12 & Bud.disp. af \\
\hline DKK & 7.781 .000 & 6.998 .000 & 6.874 .000 & $100 \%$ & EK-U
\end{tabular}

Formål

Nordisk Netværk for Voksnes Læring (NVL) blev etableret i 2005. NVL er en nordisk mødeplads, som er organiseret omkring en værtsorganisation/ hovedkoordinator og nationale netværk/ landekoordinatorer i alle de nordiske lande og kontaktmiljøer i de selvstyrende områder. NVL skal følge og analysere udviklingen inden for området voksnes læring, bygge netværk, informere om nordisk samarbejde om voksnes læring, sprede resultater og erfaringer fra rapporter, projekter, udviklingsarbejder samt bidrage med underlag til Nordisk Ministerråds arbejde. 
Som led i beslutningen om NVL fra 2013 er der tilført budgetposten 660.000 DKK fra budgetpost 2-2505-1 Dispositionsmidler - Uddannelse og forskning til budgetposten.

Prioriteringer i NVL skal fremme udvikling og implementering af strate2014 gier for livslang læring og kompetenceudvikling inden for forskellige områder af voksnes læring, bidrage til personlig udvikling og demokratisk deltagelse samt informere struktureret og strategisk om nordisk samarbejde om voksnes læring.

- Fleksibilitet i uddannelserne.

- Arbejdspladsen som læringsarena.

- Validering af realkompetencer.

- Vejledning i forhold til videre uddannelse og kompetenceudvikling.

- Fremme udviklingen af kreative og innovative i uddannelserne.

Ledelse og Planlagte udgifter 2014: 421.000 DKK

adm. Faktiske udgifter 2012: 355.000 DKK

Sekretariats- Vox, nationalt fagorgan for kompetencepolitik, Oslo. funktion NVL drives af to heltidsansatte medarbejdere, ti deltidsansatte medarbejdere i landene samt tre kontaktpersoner på Færøerne, Grønland og Åland. Ressourcen anvendes helt overvejende til faglig ledelse og faglig udvikling. Værtsorganisationen har ikke registreret tidsforbruget, men det skønnes, at mindst 90 pct. af ressourcen går til faglige opgaver. På det grundlag skønnes de samlede administrative udgifter til 421TDKK.

\section{Mobilitets- og Netværksprogrammer}

\section{2-2513-2 Nordplus}

\begin{tabular}{|l|c|c|c|c|c|} 
Valuta & Budget 14 & Budget 13 & Budget 12 & Disp./bud. 12 & Bud.disp. af \\
\hline DKK & 74.616 .000 & 73.441 .000 & 72.142 .000 & $83 \%$ & EK-U
\end{tabular}


Formål

Nordplus Horisontal og de fire sektorprogrammene

Nordplus Junior, Nordplus Høyere Utdanning, Nordplus

Voksen og Nordplus Nordiske Språk.

De overordnede målsetninger og innholdet for Nordplus 2012-2016 er beskrevet i Nordplus Programdokument. Programdokumentet skal sikre en helhetlig og transparent styring i programmet, og eies av MR-U/EK-U.

Overordnede målsetninger for Nordplus 2012-2016 er å:

- Styrke og utvikle det nordiske utdanningssamarbeidet og bidra til å skape et nordisk-baltisk utdanningsområde;

- Støtte, bygge på, dra nytte av og spre innovative produkter og prosesser på utdanningsområdet gjennom systematisk utveksling av erfaringer og god praksis;

- Bidra til utviklingen av kvalitet og innovasjon i utdanningssystemene for livslang læring i deltakerlandene gjennom utdanningssamarbeid, samt samarbeid med arbeidslivet, om utviklingsprosjekter, utveksling og nettverksbygging;

- Fremme nordisk språk og kultur og gjensidig nordisk-baltisk språklig og kulturell forståelse;

- Styrke språkforståelsen særlig blant barn og unge i de nordiske språk, primært dansk, svensk og norsk;

- Stimulere interessen for, kunnskap om og forståelse for de nordiske språk.

Prioriteringer i Prioriterte oppgaver i 2014 er å arbeide videre med for2014 enklinger og utvikling av programmet herunder blant annet:

- Arbeide systematisk og kontinuerlig for å styrke synliggjøring og utnyttelse av resultater fra programmet som helhet og enkeltprosjekt;

- Sikre bedre rapportering og statistikk fra programmet.

Ledelse og Planlagte udgifter 2014: 7.030.245 DKK (2013-tal) 
adm.

Sekretariatsfunktion
Faktiske udgifter 2012: 6.935.314 DKK

Nordplus administrasjonen er basert på et konsortium utpekt av Nordisk ministerråd, bestående av fem nasjonale programkontorer i Danmark, Finland, Island, Norge og Sverige, som hver er utpekt som hovedadministrator for et spesifikt Nordplus delprogram. Nordplus administrasjonen inkluderer de tre nasjonale programkontorer, som er utpekt av utdannings- og forskningsministrene i henholdsvis Estland, Latvia og Litauen til nasjonale informasjonskontorer for Nordplus. De utvalgte informasjonspunkter for Nordplus i Grønland, Færøyene og Åland er tilknyttet de utpekte nasjonale programkontorer i henholdsvis Danmark og Finland, og er således en del av Nordplus administrasjonen. En av de fem nordiske hovedadministratorer, Styrelsen for Videregående Uddannelser, er av Nordisk ministerråd utpekt som hovedkoordinator for Nordplus administrasjonen for perioden 01.01.2014-31.12.2016.

\section{2-2534-4 Bidrag till Nordiskt Sommaruniversitet}

\begin{tabular}{|l|c|c|c|c|c|} 
Valuta & Budget 14 & Budget 13 & Budget 12 & Disp./bud. 12 & Bud.disp. af \\
\hline DKK & 0 & 1.212 .000 & 1.191 .000 & $100 \%$ & $\begin{array}{c}\text { Styret for } \\
\text { NSU }\end{array}$
\end{tabular}

Fra 2014 skal Nordisk Sommeruniversitet (NSU) drives i regi af NorForsk.

Ved forhandlingerne mellem Nordisk Ministerråd og Nordisk Råd om budgettet for 2014 er der opnået enighed om:

-at Nordisk Sommeruniversitet (NSU) bliver underlagt NordForsk under forudsætning af, at NSU's aktivitetsniveau fortsætter. NordForsk får i 2014 i opgave at finansiere NSU's virksomhed i 2014 på et tilsvarende niveau som for 2013. 
2-2545-2 Samarbejdsnævn et for Nordenundervisning i udlandet

\begin{tabular}{|l|c|c|c|c|c|} 
Valuta & Budget 14 & Budget 13 & Budget 12 & Disp./bud. 12 & Bud.disp. af \\
\hline DKK & 0 & 1.099 .000 & 1.080 .000 & $100 \%$ & $\begin{array}{c}\text { Samar- } \\
\text { bejdsnævnet } \\
\text { for Norden- } \\
\text { undervisning } \\
\text { i Udlandet }\end{array}$
\end{tabular}

Beslutning om organisering af sprogsamarbejdet blev taget på EK-U’s møde den 5. december 2012, herunder at den virksomhed, der varetages af Samarbejdsnævnet for Nordenundervisning i Udlandet ikke længere finansieres af nordiske midler.

\section{Nordforsk}

2-3100-3 Nordforsk

\begin{tabular}{|l|c|c|c|c|c|} 
Valuta & Budget 14 & Budget 13 & Budget 12 & NMR fin. 12 & Bud.disp. af \\
\hline NOK & 123.859 .000 & 121.134 .000 & 117.003 .000 & $58 \%$ & Institutionen \\
\hline $\begin{array}{l}\text { Modsv. } \\
\text { DKK }\end{array}$ & 121.382 .000 & 118.711 .000 & 112.931 .000 & &
\end{tabular}

Formål

NordForsks overordnede mål er i henhold til statuttene å bidra til å befeste og videreutvikle Norden som en av verdens mest dynamiske regioner for forskning og innovasjon, og på den måten styrke landenes internasjo-nale konkurransekraft og sikre befolkningens levekår.

NordForsk har som hovedoppgave å fremme et effektivt samarbeid mellom de nordiske landene i spørsmål om forskning og forskerutdanning av høyeste internasjonale kvalitet gjennom å være en kompetent og effektiv samordner og aktør innen policyutvikling og forskningsfinansiering.

Från och med 1 januari 2014 ska Nordisk kommitté för bioetik och Nordiskt sommaruniversitet bedrivas i NordForsks regi. 
Prioriteringer i Den överordnade prioriteringen år 2014 är att slutföra 2014 NordForsks strategiperiod 2011-2014 samt bereda ny strategiperiod baserad på de reviderade stadgar som Nordiska ministerrådet tagit fram för NordForsk samt under ledning av en ny styrelse.

Inom de fem satsningsområden som definierats för strategiperioden 2011-2014 är huvuprioriteringarna följande:

Finansiering av nordiskt forskningssamarbete NordForsk bidrar till ökad kvalitet inom forskning i Norden. Huvudprioriteringarna inom satsningsområdet forskningsfinansiering är etablerandet av nordiska excellenscentra, initierande och deltagande i tvärvetenskapliga forskningsprogram utgående från stora samhälleliga utmaningar samt skapandet av kritisk massa och komposition inom små och spridda forskningsområden som bedöms ha stor betydelse och potential för framtiden. Samtliga satsningar inom forskningsfinansiering baserar sig på nationella prioriteringar och samfinansieras av NordForsk/Nordiska ministerrådet och nationella forskingsfinansiärer.

- En god uppföljning av pågående satsningar är en prioritet för NordForsk. År 2014 vidareförs de stora satsningarna globaliseringsinitiativet inom eScience (NeGI); programmet inom utbildningsforskning och förmedling "Education for Tomorrow"; programmet inom Hälsa och Välfärd; samt programmet inom Samhällssäkerhet. Programmen finansierar storskaliga Nordic Centres of Excellence, forskningsprojekt, forskarutbildning samt disseminationsaktiviteter. Forskarmobilitet och etablerandet av långsiktiga nätverk utgör en viktig komponent $i$ alla NordForsks satsningar.

- $\quad$ En prioritet år 2014 är att starta upp nya satsningar baserat på det planläggningsarbete som gjorts år 2013. Potentiella nya satsningar år 2014 är samarbete för grön tillväxt, samarbete om Arktis samt 
samarbete om nordiska språk och språkkultur.

- $\quad$ Uppföljning av avslutade initiativ är en prioritet. I samarbete med Nordisk Innovation och Nordisk Energiforskning koordinerar NordForsk år 2014 en slutevaluering av Toppforskningsinitiativet inom klimat, energi och miljö.

Samarbete inom forskningsinfrastruktur

Tillgång till forskningsinfrastruktur är en förutsättning för excellent forskning. NordForsk stärker nordiska forskares tillgång till forskningsinfrastruktur genom att främja gemensam användning av forskningsinfrastruktur, etablerandet av gemensam nordisk forsknings $\neg$ infrastruktur samt nordisk samordning inom europeiskt infrastruktursamarbete, där det är relevant.

- År 2014 kommer NordForsk att prioritera att ta fram och implementera lämpliga satsningar i samarbete med en nordisk rådgivargrupp för forskningsinfrastruktur, som år 2013 etablerats under NordForsk.

- Ett fortsatt prioriterat område är eInfrastruktur och arbetet inom Nordic eInfrastructure Cooperation (NeIC) vidareförs och vidareutvecklas till att omfatta nya relevanta forskningsområden.

- Användning av hälso- och sociala register är en annan prioritet.

- Slutligen prioriteras planläggning och implementering av nordiska aktiviteter - möjligen som ett storskaligt program - relaterade till European Spallation Source i Lund.

Norden-Europa-relationer

Nordiskt samarbete är en del av ett bredare europeiskt samarbete. Prioriteringarna inom satsningsområdet Europarelationer är att synliggöra resultat av det nordiska forskningssamarbetet i Europa och främja samarbete mellan nordiska och europeiska forskningsaktörer där det finns tydligt nordiskt mervärde och en samsyn mellan de nordiska länderna. NordForsks ambition är att främja 
nordiskt-europeiskt forskningssamarbete då detta bedöms lämpligt.

Forskningsanalys och forskningspolitik

Samtliga storskaliga nordiska satsningar baserar sig på grundlig analys och förberedande aktiviteter bl.a. inom s.k. NORIA-net, som etableras av NordForsk i samarbete med nationella forskningsfinansiärer och policyaktörer. Här prioriteras en god dialog mellan forskningsarenan och den politiska arenan, analys av det nordiska forskningslandskapet samt ett stärkt samarbete mellan forsknings- och utbildningssektorn och andra sektorer.

- Det kontinuerliga arbetet med analysen av det nordiska forskningslandskapet är den centrala prioriteringen inom satsningsområdet. Analysen omfattar såväl strukturen hos landskapet som vilka prioriteringar och prestationer som görs däri. Landskapsanalysen är en flerårig aktivitet som sträcker sig genom NordForsks strategiperiod. Fokus i analysen år 2014 kommer att ligga på prioriteringar och prestationer.

- $\quad$ En prioritering år 2014 är att aktivt bidra till stärkt samordning av nordiskt forskningssamarbete. Detta gör NordForsk bl.a. genom strategiska partnerskap med Nordisk Samarbetsnämnd för Naturvetenskaper (NOS-N), Nordisk Samarbetnämnd för Medicin (NOS-M) och Nordic eInfrastructure Cooperation (NeIC) som alla ägs av de nationella forskningsråden. Det görs även genom Nordisk Kommitté för Jordbruks- och matforskning (NKJ) som organisatoriskt hör under MR-FJLS Nordic Trial Alliance (på uppdrag av NMR) samt genom administration och koordinering av stora samfinansierade forskningsprogram, som beskrivet ovan.

Kommunikation

NordForsk vill bidra till långsiktiga kunskapsbaserade framsteg i de nordiska samhällena. Inom satsningsområdet kommunikation prioriteras synliggörandet av resultat av 
- det nordiska forskningssamarbetet,

- NordForsks roll som plattform för dialog mellan aktörer och sektorer inom det nordiska forskningssamarbetet, samt

- $\quad$ vikten av en strategisk mix av kommunikationskanaler för att nå de riktiga målgrupperna.

Kommunikation av samarbetsaktiviteter och forskningsresultat ingår som en integrerad del i alla NordForsks aktiviteter och en prioritet är att vidareutveckla denna förmedlingsroll.

En prioritet år 2014 är deltagande i EuroScience Open Forum (ESOF) vilket organiseras vartannat år och som denna gång hålls i Köpenhamn, Danmark.

En annan prioritet är en större konferens för att förmedla resultaten av Toppforsknings $\rightarrow$ initiativet inom klimat, energi och miljö som genomgått en slutevaluering år 2014.

NordForsk får i mål- och resultatkontrakt för 2014 i uppdrag att sköta verksamheten för Nordisk kommitté för bioetik och Nordiskt sommaruniversitet. NordForsk blir därmed sekretariat och ansvarig för verksamheten.

Ved forhandlingerne mellem Nordisk Ministerråd og Nordisk Råd om budgettet for 2014 er der opnået enighed om:

-at undersøge, om der findes mulige effektiviserings- og rationaliseringsgevinster ved at sammenlægge driftsfunktioner i de tre separate organisationer, der udgør Nordisk Center i Oslo. Styring af institutionerne udredes i generalsekretærens moderniserings-arbejde.

-at Nordisk Sommeruniversitet (NSU) bliver underlagt NordForsk under forudsætning af, at NSU's aktivitetsniveau fortsætter. NordForsk får i 2014 i opgave at finansiere NSU's virksomhed i 2014 på et tilsvarende niveau som for 2013. 
Kontrakt- Kontraktperioden 2007-2009 forlænges med et år ad ganperiode gen frem til og med 2014.

Kontrakt- $\quad$ Nye vedtægter er under udarbejdelse.

status

Økonomi Inga anmärkningar.

Ledelse og Planlagte udgifter 2014: 6,1 MNOK

adm. $\quad$ Faktiske udgifter 2012: 5,9 MNOK

2-3140-2 Nordisk komité for Bioetik

\begin{tabular}{|l|c|c|c|c|c|} 
Valuta & Budget 14 & Budget 13 & Budget 12 & Disp./bud. 12 & Bud.disp. af \\
\hline DKK & 0 & 1.020 .000 & 1.002 .000 & $97 \%$ & $\begin{array}{c}\text { Nordisk } \\
\text { kommitté för } \\
\text { bioetik }\end{array}$
\end{tabular}

Fra 2014 skal Nordisk komité for Bioetik drives i regi af NordForsk.

\section{Forskning i øvrigt}

2-3180-2 Nordisk Institut for Teoretisk Fysik (Nordita)

\begin{tabular}{|l|c|c|c|c|c|} 
Valuta & Budget 14 & Budget 13 & Budget 12 & Disp./bud. 12 & Bud.disp. af \\
\hline DKK & 8.869 .000 & 10.911 .000 & 10.718 .000 & $100 \%$ & $\begin{array}{c}\text { Styret for } \\
\text { Nordita }\end{array}$
\end{tabular}

Formål

Nordita är ett internationellt forskningsinstitut placerat i Stockholm och är ett samarbetsorgan under NMR. Från år 2007 är Kungliga Tekniska Högskolan (KTH) och Stockholms Universitet (SU) värdar för Nordita. Institutets främsta uppgift är att utföra grundforskning på högsta internationella nivå inom teoretisk fysik, samt att främja forsknings- och utbildningsverksamhet i Norden. För att uppnå detta bedriver institutet förutom egen grundläg- 
gande forskning även vetenskaplig programverksamhet med stort nordiskt deltagande bestående av 1-2 månaders perioder av intensiv forskning kring ett specifikt tema $\mathrm{i}$ samarbete med inbjudna gästforskare. Vid Nordita genomförs även konferenser och workshops inom teoretisk fysik. Nordita har ett stipendiatprogram för högt meriterade unga forskare och utbildar doktorander genom handledning och vid kurser och forskarskolor.

Bidraget fra Nordisk Ministerråd vil i 2014 blive reduceret med $20 \%$ i forhold til 2013, og det vil være nødvendigt at tage ledelsesmæssige skridt for at tilpasse samarbejdsorganet til denne situation.

Prioriteringer i Nordita prioriterar verksamheter som bidrar till att stärka 2014 forskningen inom teoretisk fysik i Norden. I detta ingår grundforskning, programverksamhet, stipendie- och gästforskarprogram samt forskarskolor. Nordita har följande prioriteringar under året:

- Första prioritet är att genomföra forskning på högsta internationella nivå inom ett brett spektrum av teoretisk fysik.

- Vidare att genomföra särskilda vetenskapliga program som täcker ett brett urval av vetenskapliga områden. Under 2014 är följande vetenskapliga program planerade: "News in Neutrino Physics", "What is the Dark Matter?", "Dynamics of Particles in Flows: Fundamentals and Applications", "Novel Directions in Frustrated and Critical Magnetism", "Quantum Engineering of States and Devices" och "Control of Ultrafast Quantum Phenomena".

- Att genomföra ett antal specialiserade konferenser och workshops inom teoretisk fysik och närstående områden.

- Årets "Nordita Winterschool on Theoretical Physics", en forskarskola för doktorander och unga forskare främst från Norden, kommer att hållas under två veckor i januari 2014 med ämnesområde kondenserade materiens fysik. 
Ledelse og adm.
Planlagte udgifter 2014: De administrativa kostnaderna kommer att reduceras något under 2014 jämfört med 2013 till följd av en minskning av den nordiska finansieringen.

Faktiske udgifter 2012: 33347000 SEK (DKK 28678 000 med NMR kurs 0,86 ) varav administrativa kostnader 5751000 SEK (DKK 4946000 med NMR kurs 0,86).

Sekretariats- Kungliga Tekniska Högskolan. funktion

\section{2-3181-2 Nordisk Institutt for sjørett (NIfS)}

\begin{tabular}{|l|c|c|c|c|c|} 
Valuta & Budget 14 & Budget 13 & Budget 12 & Disp./bud. 12 & Bud.disp. af \\
\hline DKK & 2.643 .000 & 3.251 .000 & 3.194 .000 & $100 \%$ & $\begin{array}{c}\text { Styret for } \\
\text { NIfS }\end{array}$
\end{tabular}

Formål

Nordisk institutt for sjørett (NIfS) er nu et samarbejdsorgan under NMR.

Ejerskabet for NIfS blev overført til Universitet i Oslo (UiO) i 2004.

Nordisk institutt for sjørett (NIfS) skal fremme forskning og undervisning i de nordiske land i sjørett, alminnelig transportrett, energi- og petroleumsrett og beslektede fagområder. NIfS skal videre opprettholde en høy kompetanse $\mathrm{i}$ alminnelig formuerett.

NIfS skal innen sine fagområder drive forskning og forskerutdanning, tilby undervisning og videreutdanning, utgjøre et internasjonalt kompetansesenter, utvikle internasjonalt samarbeid og sikre forskningsformidling.

Bidraget fra Nordisk Ministerråd vil i 2014 blive reduceret med $20 \%$ i forhold til 2013, og det vil være nødvendigt at tage ledelsesmæssige skridt for at tilpasse samarbejdsorganet til denne situation. 
Prioriteringer i NIfS har i sin virksomhet først og fremst fokus på å 2014 fremme og videreføre det nordiske samarbeidet innen rammene for sitt mandat. På grunn at rettens økende grad av internasjonalisering får imidlertid aktiviteten på instituttet også en mer globalisert innretning. NIfS har følgende prioriterte forskningsområder:

- Forskning knyttet til kontrakter i skipsfarts-, off shore- og energisektoren, herunder en rekke ulike typer av kontrakter knyttet til skip, offshoreinstallasjoner, transport og energi. Særlig fokus rettes mot multimodale transporter, offshore certepartier og energioptimaltransport. Planen er også å se nærmere på kontrakter innenfor luftfarten. Denne forskningen får også mer internasjonal innretning gjennom forskergruppen Internasjonale kontrakter.

- Forskning knyttet til sikkerhet og ansvar innenfor skipsfarts, offshore- og energisektoren. Dette inkluderer fokus på nordområdene og til Østersjø/Baltikumområdet og spørsmål knyttet til miljøutslipp fra skip.

- Forskning knyttet til havrett. Dette kommer i forlengelsen av satsningen på sikkerhet og ansvar, og vil fortsette fokuset på sårbare havområder og miljøspørsmål.

- Forskning innen energi-, klima- og miljørett med fokus på globaliserings- og klimaspørsmål.

- Forskning innen energimarkedsrett dvs. reguleringen av henholdsvis gassmarkedet og kraftmarkedet.

Ledelse og Planlagte udgifter 2014: 1.106000 NOK adm. Faktiske udgifter 2012: 1.381960 NOK for år 2012

Sekretariats- Universitetet i Oslo. funktion 


\section{2-3182-2 Nordisk Institut for Asienstudier (NIAS)}

\begin{tabular}{|l|c|c|c|c|c|} 
Valuta & Budget 14 & Budget 13 & Budget 12 & Disp./bud. 12 & Bud.disp. af \\
\hline DKK & 4.190 .000 & 5.155 .000 & 5.064 .000 & $100 \%$ & NIAS styre
\end{tabular}

Formål

NIAS blev indlejret på Københavns Universitet i 2005 og er nu et samarbejds-program under Nordisk Ministerråd. NIAS arbejder i et nordisk konsortium sammen med Københavns Universitet (KU) som hovedpartner og værtsinstitution og medlemsinstitutionerne i Nordic NIAS Council (NNC). NIAS samarbejder med KU om implementering af dets strategiske satsning på Asien området, Asia Dynamics Initiative.

NIAS er et uafhængigt nordisk forsknings- og serviceinstitut, som genererer og kommunikerer indsigt i Asiens moderne samfundsudvikling set $i$ en historisk og kulturel kontekst. NIAS dækker hele Asien.

NIAS aktiviteter omfatter:

- Grundforskning og anvendt forskning.

- Egen videnskabelig publikation gennem etablerede publikationskanaler samt nordisk og international videnskabelig publicering på eget forlag, NIAS Press.

- Støtte til forskeruddannelse i de nordiske lande og undervisning på Master og $\mathrm{PhD}$-niveau.

- Arbejdsstipendier for Master og PhD studerende, NIAS SUPRA Programme

- Informations- og biblioteksservice i det nordiske område, NIAS LINC - NIAS Library and Information Centre.

- Intellektuel udveksling og støtte til nordiske landespecifikke og tematiske netværk.

- Samarbejde med Nordisk Ministerråd (NMR) omkring udvikling af øvrige aktiviteter i Asien og NMR's globaliseringsstrategi, hvor udvikling af relationer til Asien vil spille en rolle.

- Konsulentarbejde og rådgivning for NMR. 
Gennem samarbejde med NNC, 23 nordiske universiteter og forskningsinstitutioner, bidrager NIAS til koordinering, konsolidering og ekspansion af Asienstudier i de nordiske lande.

Bidraget fra Nordisk Ministerråd vil i 2014 blive reduceret med $20 \%$ i forhold til 2013, og det vil være nødvendigt at tage ledelsesmæssige skridt for at tilpasse samarbejdsorganet til denne situation.

Prioriteringer i 2014

Ledelse og adm.

Sekretariatsfunktion
- $\quad$ Styrke eksternt finansierede forskningsprojekter med fokus på Asiens voksende betydning for Norden og Europa. Projektet: Asia and the Changing Arctic har højeste prioritet.

- Fortsat styrke samarbejdsrelationerne mellem de nordiske asienforskningsmiljøer, samt mellem disse og det europæiske asienforskningsmiljø gennem medlemskabet i The European Alliance of Asian Studies, og samarbejdet med Asia-Europe Foundation.

- Promovere udviklingen af forskningscentre og programmer i Asien med fokus på Norden, bl.a. gennem netværksudvikling og etablering af komparative forskningsprojekter. To nordisk-asiatiske forskernetværk er oprettet, og et nordisk center er under etablering i Korea.

- Følge udviklingen i Asien generelt med henblik på NIAS funktion som rådgivende organ for nordiske offentlige og private interessenter, herunder de nordiske nyhedsmedier.

Planlagte udgifter 2014: 1.178.979 DKK. Faktiske udgifter 2012: 1.382.000 DKK.

Sekretariatsfunktionen ligger på NIAS. Regnskab/finansiel styring og IT-ydelser sker i samarbejde med Københavns Universitets administration. 
2-3184-2 Nordisk vulkanologisk institut (NORDVULK)

\begin{tabular}{|l|c|c|c|c|c|} 
Valuta & Budget 14 & Budget 13 & Budget 12 & Disp./bud. 12 & Bud.disp. af \\
\hline DKK & 4.280 .000 & 5.267 .000 & 5.174 .000 & $100 \%$ & Styret i \\
& & & & & NORDVULK
\end{tabular}

Formål

Nordiskt Vulkanologiskt Center (NORDVULK) er et nordisk forskningscenter indenfor emnet vulkanologi. Centeret er idag en integreret del af det Geovidenskabelige Institut på Islands Universitet. NORDVULK's formål er at opretholde et nordisk kompetance center indenfor forskning i vulkanologi og relaterede emner, herunder at vejlede og uddanne yngre nordiske forskere indenfor feltet således at den faglige ekspertise indefor disse emner fremmes i de nordiske lande. NORDVULK udbyder hvert år minimum 5 stillinger til nordiske yngre forskere samt $\mathrm{PhD}$ studerende. Forskning udført på NORDVULK publiceres $\mathrm{i}$ internationale tidsskrifter, og præsenteres på både nordiske samt internationale konferencer. Desuden stræber NORDVULK efter at afholde årlige forskerskoler med nordisk deltagelse, hvor der sættes fokus på varierende emner indenfor vulkanologi.

Bidraget fra Nordisk Ministerråd vil i 2014 blive reduceret med $20 \%$ i forhold til 2013, og det vil være nødvendigt at tage ledelsesmæssige skridt for at tilpasse samarbejdsorganet til denne situation.

Prioriteringer i 2014
- At opretholde og udvikle NORDVULK's virksomhed indenfor både vulkanologisk forskning på internationalt niveau, samt uddannelse af yngre nordiske forskere.

- Understøtte den internationale synlighed NORDVULK nyder som et nordisk kompetencecenter i vulkanologi, gennem yderligere udbygning og forstærkning af internationalt samarbejde i forskningsprojekter.

- Understøtte den almene Nordiske interesse for Jordens processer vækket ved Islandske vulkanudbrud i 
de senere år, gennem PR aktiviteter i form af forelæsninger, samt repræsentation af NORDVULK ved relevante offentlige møder.

Ledelse og Planlagte udgifter 2014: De administrative omkostninger adm. for 2014 forventes at være ca. 10.000.000 ISK. Faktiske udgifter 2012: 8.518.000 ISK.

De lavere omkostninger i 2012 end forudgående år skyldes af barselsorlov i administrationen dele af året

Sekretariats- Sekretariatsfunktionen udføres af Islands Universitet. funktion

\section{2-3185-2 Nordisk Samisk Institut (NSI)}

\begin{tabular}{|l|c|c|c|c|c|} 
Valuta & Budget 14 & Budget 13 & Budget 12 & Disp./bud. 12 & Bud.disp. af \\
\hline DKK & 1.618 .000 & 1.991 .000 & 1.956 .000 & $100 \%$ & $\begin{array}{c}\text { Styret for } \\
\text { Samisk } \\
\text { Høgskole }\end{array}$
\end{tabular}

Formål

Eierskapet for Nordisk Samisk Institutt (NSI) blev i 2005 overført til Sámi allaskuvla - Samisk høgskole. Høgskolen skal produsere og effektivt formidle kvalitetsmessig god forskning som møter kunnskapsbehov og kunnskapsutfordringer i det samiske samfunn, auke kunnskapen om og forståelsen for samiske forhold og samenes situasjon som minoritet og urfolk i samfunnet generelt, i Norden og internasjonalt. Hensikten er å bidra til utvikling av bærekraftige samiske lokalsamfunn.

Bidraget fra Nordisk Ministerråd vil i 2014 blive reduceret med $20 \%$ i forhold til 2013, og det vil være nødvendigt at tage ledelsesmæssige skridt for at tilpasse samarbejdsorganet til denne situation.

Prioriteringer i År 2014 er første året av nye 4-årige forskningsprogram2014 met "Samisk forskning for det samiske samfunn". Programmet omfatter primært forskning innen områdene: 
- Videreutvikling av samisk som vitenskapsspråk, spesiell innen fagområdene språkforskning, humaniora, pedagogikk og urfolksforskning.

- Forskning på samisk tradisjonell kunnskap, kartlegging og dokumentasjon av samiske tradisjonskunnskaper. Utvikling av forskningsprosjekter og metoder for innsamling, vern, kunnskapslagring, bruk og formidling står sentralt.

- Utvikling av forskningskompetanse innen samiske tradisjonelle næringer og tradisjonell naturforståelse og ressursforvaltning.

- Samisk rettshistorie og rettsutvikling i nordisk samiske sammenheng samt rettslige spørsmål knyttet til samenes og andre urfolks kulturarv og samfunnsutvikling

- Forskning på det moderne samiske samfunn, inkludert utdanningsforskning.

Ledelse og Planlagte udgifter i 2014: NOK 1.920.000 (DKK adm. $\quad 1.804 .800$ med NMR-kurs 0,94)

Faktiske udgifter for 2012: De administrative kostnadene for 2012 var NOK 2.308.130 (DKK 2.169.642).

Sekretariats- $\quad$ Sekretariatsfunksjonen for Nordisk Samisk Institutt (NSI) funktion er samorganisert med Samisk høgskoles øvrige virksomhet.

Direktør for Samisk høgskole det har øverste administrative ansvaret for gjennomføringen av forskningsprogrammet "Samisk forskning for det samiske samfunn". 


\section{Social- og Helsepolitik}

\section{Generel indledning}

Generelt De nordiske regeringers samarbejde inden for social- og sundhedssektoren ledes af Ministerrådet for social- og helsepolitik (MR-S). Den samlede budgetramme for social- og sundhedssektoren i 2014 er på 40.293 TDKK. Budgetrammen dækker projektmidler og samarbejdsorganerne Nordisk Institutt for Odontologiske Materialer (NIOM), Nordisk medicinalstatistisk komité, Nordisk socialstatistisk komité (NOMESKO/NOSOSKO) og Rådet for funktionshinder samt institutionerne Nordens Velfærdscenter (NVC) og Nordic School for Public Health NHV (NHV). NHV er finansieret direkte fra landene og indgår derfor ikke i de akkumulerede beløb, men er ellers underlagt samme vilkår som institutioner finansieret af Nordisk Ministerråd.

Det nordiske samarbejde på social- og sundhedsområdet er baseret på fælles værdier, som er koncentreret om udvikling og bæredygtigheden af det nordiske velfærdssamfund i et Europæisk/globalt perspektiv, herunder fjernelse af grænsehindringer mellem de nordiske lande. Endvidere koncentreres samarbejdet om udvikling af Nordens samarbejde med Nordens nærområder samt udvekslingen af national information og erfaring.

Prioriteringsbudget: I 2013 upprättades en prioriteringsbudget i Nordiska ministerrådet. Prioriteringsbudgetet avlöste 2007-2012 års globaliseringsbudget. MR-S är tillsammans med MR-U ansvarigt för programmet Hållbar nordisk välfärd, ett tre-årigt program som får finansiering av prioriteringsbudgeten.

Det prioriterede tema for sektorens projektmidler: Som led $i$ en politisk prioritering og for at sikre en synlig og målbar indsats besluttede MR-S på dets møde i juni 2012, at sektorens projektmidler for perioden 2013-2015 koncentreres om temaet "Inklusion af udsatte unge $\mathrm{i}$ arbejds- 
liv og uddannelse". Temaet har baggrund i den økonomiske krise i Europa, som har sat velfærdsstaten under pres og formålet er en bedre komparativ oversigt over politikker for at inkludere udsatte unge $\mathrm{i}$ arbejdslivet og uddannelse i de nordiske lande. Temaet sætter særlig fokus på den øgede andel unge med psykiske lidelser, som modtager førtidspension/uførepension.

Nabosamarbejde og samarbejde om bekæmpelse af menneskehandel: MR-S er engageret i samarbejdet med vores nabolande, særligt Nordvestrusland. Hovedindsatsområderne er sociale initiativer målrettet udsatte grupper og indsats mod HIV/AIDS, samt indsats mod menneskehandel. Ministerrådet fortsætter med aktiv deltagelse i Northern Dimension Partnership in Public Health and Social Wellbeing (NDPHS).

Øvrige satsninger: De nordiske lande fortsætter med at fokusere på udviklingen og bæredygtigheden af de nordiske sundhedssystemer. Målet er at placere Norden som foregangsregion på disse felter og samtidig imødekomme globaliseringsudviklingen på sundhedsområdet.

Udmøntning af besparelse $\mathrm{i}$ budget 2014

Ministerrådets styringsdokumenter
MR-SAM vedtog $\mathrm{i}$ forbindelse med budget 2014 en reduktion på 1.772 TDKK på MR-S budgetramme, deraf er pålagt administrative besparelse på 342 TDKK. Denne reduktion er udført således at projektmidlerne til MR-S prioriterede tema "Inklusion af udsatte unge i arbejdsliv og uddannelse" (2.500 TDKK) blev friholdt for enhver besparelse. Besparelsen på 1.430 TDKK er fordelt ligeligt på sektorens andre budgetposter. Besparelsen på de administrative udgifter udmøntes gennem reduktioner af bevillinger til samarbejdsorganer i henhold til fordelingsnøgle, som er baseret af antal medarbejdere i de respektive organer. Den samlede besparelse på MR-S rammen i 2014 er 4,3 \% i henhold til rammen i 2013 (i 2013 priser).

Strategi for social- og sundhedsområdet:

Det nordiske social- og sundhedspolitiske samarbejde bygger på en strategi som blev godkendt af MR-S i 2012 2013. Der er tale om et overordnet politisk dokument, som 
komplementeres af formandskabets prioriteringer, og det der besluttes af MR-S.

Strategi for anvendelse af sektorens projektmidler:

Projektstrategien for 2013 og frem er et vigtigt led i udmøntningen af centrale prioriteringer for MR-S samarbejdsområder. Projektstrategien skal sikre, at projektmidler anvendes effektivt, fokuseret og er koncentreret om større projekter.

Samarbejdsaftale mellem NMR og Skt. Petersborg: En tværsektoriel rammeaftale med Skt. Petersborg, Rusland om samarbejde inden for social-, sundhed- og ligestillingsområdet, herunder indsatser mod menneskehandel.

Resumé af Ministerrådets resultater i 2012
Prioriteringsbudgeten - Hållbar nordisk välfärd: Nordiska ministerrådet har beslutat att från och med 2013 upprätta en prioriteringsbudget för prioriterade insatser. MR-S har under 2012 förberett igångsättandet av en satsning på välfärd. Programmet blir ett tre-årigt program som MR-S ansvarar för tillsammans med MR-U. Programmet fokuserar på följande tre insatsområden: 1) Utbildning och arbete för välfärd, 2) Forskning för välfärd och 3) Infrastruktur för välfärd.

Sektorns projektmedel: Under 2011-2012 har MR-S:s projektmedel använts till en satsning på temat "Tidiga förebyggande insatser för familjer i risk för social marginalisering". Inom ramen för temat har det fokuserats på (1) Aktuell forskning inom området risk och skyddsfaktorer (2) Lovande exempel på tidiga interventioner från de nordiska länderna (3) Förenklad tillgång till service ur ett brukarperspektiv och (4) Låt barnens röst höras. Projektet avslutades i december 2012 med slutkonferens med 300 deltagare. Resultaten från projekten pekar på att tidiga insatser för familjer och barn både är en samhällsekonomisk vinst samt leder till högre livskvalitet. Resultaten från projektet sammanfattas i inspirationshäften. I tillägg kommer förmedlingsseminarier i de nordiske lände för att sprida information till en bredare krets genomföras. 
Øvrige satsninger:

Fortsat nordisk samarbejde i forhold til den tiltagende centralisering og specialisering af de nordiske landes sundhedsvæsener. Formålet med et nordisk samarbejde på dette område er at sikre en højere kvalitet $i$ varetagelsen af de højtspecialiserede funktioner end den, de enkelte lande kan varetage hver for sig. I 2012 har en nordisk expertgrupp arbetat fram ett konkret förslag till nordiskt samarbete om högspecialiserade behandlingar. Ett framtida nordiskt samarbete föreslås fokusera på 1) Professionellt erfarenhets- och kompetensutbyte, 2) Gemensamma nordiska databaser/kvalitetsregister, 3) Gemensamma nordiska procedurer.

Norden er foregangsregion når det gælder en langvarig og udbredt anvendelse af avancerede e-helsetjenester. Samtidig deltager de nordiske lande nu aktivt i EU-projekter hvor der er unik mulighed for at Norden kan være drivkraft i det europæiske arbejde og kan gå hurtigere fremad end andre lande i Europa. I 2012 arbejdede den nordiske eHelsegruppe med kortlægning af gruppens strategi for eHelse i de nordiske lande.

MR-S besluttede i 2010 at de nordiske lande skulle gennemføre en vurdering af samarbejde om kliniske studier. Store kliniske multicenterstudier er den metode der anvendes til at måle, med så stor sikkerhed og præcision som muligt, om nye behandlinger er effektive og sikre. Dette kræver store grupper af patienter, som er vanskeligt at opnå på nationalt plan i de nordiske lande, især hvad angår små patientgrupper eller sjældne sygdomme. Med en befolkning på omkring 25 millioner mennesker kan de nordiske lande være en god base for gennemførelsen af kliniske multicenterstudier og lægemiddelforsøg. Den nordiske arbejdsgruppe om kliniske multicenterstudier fremlagde i 2012 et konkret forslag om samarbejde i 2012 som blev godkendt.

MR-S har i 2012 også besluttet at igangsætte forskning på 
området social ulighed $i$ sundhed og velfærd inden for programmet Holdbar Nordisk Velfærd i 2013.

Samarbejde med nabolandene: Nordisk Ministerråds Sekretariat (NMRS) har aktivt deltaget i Northern Dimension Partnership in Public Health and Social Wellbeing (NDPHS). I 2012 er der gennemført en fokuseret indsats mod menneskehandel gennem et samlet treårigt program som afsluttes i 2013. Programmet består af fem delprojekter, der skal fremme en helhedsorienteret indsats på tværs af ministerråd inden for den nordlige dimensions region.

Nordisk Handikappolitisk Råd (NHR): NHR blev evalueret i 2009. Evalueringen viste, at der eksisterer et værdifuldt fællesskab på Handikapområdet i Norden, men at NHR har haft begrænset politisk gennemslagskraft. Et udvalg fik i 2010 mandat til at vurdere det fremtidige nordiske samarbejde på området. Udvalget har i 2011 leveret en rapport til MR-S. MR-S skal træffe beslutning om en rekommandation til MR-SAM om struktur og organisering af det fremtidige nordiske handikappolitiske samarbejde i 2013.

Nordens Velfærdscenter (NVC): NVC har i 2012 gennemført et stort antal aktiviteter. Velfærdspolitiske udfordringer og løsninger har stået som fokusområde på tværs af NVC's fem indsatsområder. I forlængelse heraf har NVC afsluttet to større projekter "Tidlig forebyggende indsatser for familier i risiko af social marginalisering" og "arbejdsinkludering af udsatte grupper" der bl.a. sætter fokus på personer med funktionshinder. Derudover er en antologi om den nordiske velfærdspolitiske udvikling inden for alkohol og narkotikaområdet publiceret. Velfærdsteknologi er ligeledes et fokusområde og der er produceret et temahæfte om ældre og informationssamfundet og om velfærdsteknologi og kronikere.

Nordisk højskole for folkesundhedsvidenskab (NHV): I 2011 besluttede MR-S at udføre en udredning af NHV og i 2012 har et nordisk konsulentkonsortium udarbejdet en 
rapport, som skal danne et grundlag for diskussion og beslutninger om NHV's fremtid. Den manglende akkreditering af skolens eksamener blev et tydeligere problem i 2012. Den i 2011 konstituerede rektor blev ansat i foråret 2012.

Nordisk Institutt for Odontologiske Materialer as (NIOM): I 2012 har NIOM haft 44 forskningsprojekter på forskellige stadier fra planlægning, via gennemførelse til publicering, og publiceret 11 forskningspublikationer i internationale tidsskrifter. 16 projekter er baseret på tværvidenskabeligt samarbejde, både internt i NIOM og med eksterne samarbejdspartnere. Syv forskningsprojekter er af samnordisk karakter. Fire gæsteforskere fra universiteter og højskoler i Finland, Sverige og Island har haft ophold på NIOM. Derudover fortsatte samarbejdet med tidligere gæsteforskere fra Danmark og Sverige. Der har været arbejdet med at videreudvikle produktdatabasen til en informationsportal for dentale biomaterialer. I 2012 har Helse- og omsorgsdepartementet i Norge i tillæg til NMR budget finansieret NIOM direkte med 7.117.775 NKK.

Nordisk medicinalstatistisk komité (NOMESKO): I 2012 arbejdede NOMESKO på den årlige publikation "Health Statistics in the Nordic Countries"/"Helsestatistik for de nordiske lande" som skal udgives primo 2013. NOMESKO har også arbejdet på en temapublikation om finansieringen for sundhedsvæsenet som skal udgives primo 2013.

Nordisk socialstatistisk komité (NOSOSKO): I 2012 udgav NOSOSKO den årlige publikation "Social tryghed i de nordiske lande" henholdsvis på dansk og engelsk. Projektet om den nordiske velfærdsstat blev afsluttet i 2012. Dette har ført til udgivelse af en nyrevideret og kraftigt udvidet udgave af "Utfordringer for den nordiske velferdsstaten". 


\begin{tabular}{|c|c|c|c|c|c|}
\hline & \multirow{2}{*}{$\begin{array}{c}\text { Budget } \\
2014\end{array}$} & \multirow{2}{*}{$\begin{array}{c}\text { Budget } \\
2013\end{array}$} & \multicolumn{2}{|c|}{ Difference } \\
\hline & & & & $+/-$ & $\%$ \\
\hline \multicolumn{2}{|c|}{ MR-S (TDKK) } & 40.293 & 40.859 & -566 & $-1,4 \%$ \\
\hline & Projektmedel & 19.151 & 19.595 & -444 & $-2,3 \%$ \\
\hline $4-4310-1$ & Projekmedel - Social- och hälsovårdspolitik & 5.725 & 5.756 & -31 & $-0,5 \%$ \\
\hline $4-4320-1$ & $\begin{array}{l}\text { Rådet för nordiskt samarbete om funktions- } \\
\text { hinder }\end{array}$ & 1.106 & 1.142 & -36 & $-3,2 \%$ \\
\hline $4-4340-1$ & Nomesko og Nososko & 1.864 & 1.916 & -52 & $-2,7 \%$ \\
\hline \multirow[t]{2}{*}{$4-4382-2$} & $\begin{array}{l}\text { NIOM AS - Nordisk institutt for Odontolo- } \\
\text { giske Materialer }\end{array}$ & 10.456 & 10.781 & -325 & $-3,0 \%$ \\
\hline & Institutioner & 21.142 & 21.264 & -122 & $-0,6 \%$ \\
\hline $4-4380-3$ & Nordens Välfärdcenter & 21.142 & 21.264 & -122 & $-0,6 \%$ \\
\hline $4-4381-3$ & $\begin{array}{l}\text { Nordiska högskolan för folkhälsovetenskab } \\
\text { (NHV)* }\end{array}$ & 40.010 & 38.297 & 1.713 & $4,5 \%$ \\
\hline \multicolumn{2}{|c|}{ Opdelt på kategorier } & 40.293 & 40.859 & $100 \%$ & $100 \%$ \\
\hline & Projektmidler & 8.695 & 8.814 & $21,6 \%$ & $21,6 \%$ \\
\hline & Programlignende aktiviteter & 10.456 & 10.781 & $25,9 \%$ & $26,4 \%$ \\
\hline & Institutioner & 21.142 & 21.264 & $52,5 \%$ & $52,0 \%$ \\
\hline
\end{tabular}

\section{Projektmedel}

4-4310-1 Projektmidler - Social- och hälsvårdspolitik

\begin{tabular}{|l|c|c|c|c|c|} 
Valuta & Budget 14 & Budget 13 & Budget 12 & Disp./bud. 12 & Bud.disp. af \\
\hline DKK & 5.725 .000 & 5.756 .000 & 5.654 .000 & $94 \%$ & MR-S/EK-S
\end{tabular}

Formål

Projektmidlerne anvendes med henblik på at styrke en koncentreret og sammenhængende indsats, hvor projekterne understøtter hinanden, fremmer synergieffekt og er policyskabende.

Prioriteringer i Som led i en politisk prioritering og for at sikre en synlig 2014 og målbar indsats vil sektorens projektmidler blive målrettet et specifikt temaområde gældende for perioden 2013-2015. MR-S tog på deres møde i juni 2012 beslutning om at sektorens projektmidler for perioden 20132015 koncentreres om temaet "Inklusion af udsatte unge i arbejdsliv og uddannelse". 
4-4320-1 Rådet för nordiskt samarbete om funktionshinder

\begin{tabular}{|l|c|c|c|c|c|} 
Valuta & Budget 14 & Budget 13 & Budget 12 & Disp./bud. 12 & Bud.disp. af \\
\hline DKK & 1.106 .000 & 1.142 .000 & 1.122 .000 & $100 \%$ & NVC
\end{tabular}

Formål

Rådet för nordiskt samarbete om funktionshinder är ett rådgivande organ i förhållande till hela Nordiska Ministerrådet, MR-S kommer dock att ha huvudansvaret för rådets arbete. Rådets huvuduppgift är att ge inspel till handlingsplanen för det nordiska funktionshinderarbetet. MR-S har ansvaret for handlingsplanen. Andre Ministerråd inviteres der hvor det er relevant.

Prioriteringer i Det nordiska funktionshindersamarbetet har genomgått en 2014 omorganisering. Fokus för det nya rådet under 2014 är att följa upp verkställandet av den nya 3 åriga handlingsplanen för funktionshinderområdet.

Ledelse og Planlagte udgifter 2014: 850.000 SEK

adm. Faktiske udgifter 2012: 870.000 SEK

Sekretariats- Nordens Velfærdscenter (NVC) funktion

\section{4-4340-1 Nomesko och Nososko}

\begin{tabular}{|l|c|c|c|c|c|} 
Valuta & Budget 14 & Budget 13 & Budget 12 & Disp./bud. 12 & Bud.disp. af \\
\hline DKK & 1.864 .000 & 1.916 .000 & 1.882 .000 & $100 \%$ & $\begin{array}{c}\text { Statens } \\
\text { Serum Insti- } \\
\text { tut, Danmark }\end{array}$
\end{tabular}

Formål

Det nordiske samarbejde om medicinal- og socialstatistik skal på området sikre sammenlignelige statistikker mellem de nordiske lande, drive internationalt og koordinerende arbejde, påtage sig udviklingsopgaver og drive publikations- og informationsvirksomhed.

Prioriteringer i NOMESKO forventer i 2014 at udgive "Helsestatistik for 2014 de nordiske lande" på både dansk og engelsk og to tema- 
udgivelser, om henholdsvis ældres helse og social ulighed i dødelighed. NOSOSKO forventer i 2014 at udgive "Social tryghed i de nordiske lande" på både dansk og engelsk og en temaudgivelse om effektiv pensionsalder. I 2014 vil der desuden blive gennemført en fortsat udvikling af NOMESKO og NOSOSKO's fælles hjemmeside og database, og en videreudvikling af digitale nyhedsbreve om komitéernes virksomhed, begge dele for at øge kendskabet til kommitéernes arbejde og tilgængeligheden af sammenlignelig nordisk sundheds- og socialstatistik.

Ledelse og Planlagte udgifter 2014: 240.000 DKK

adm. $\quad$ Faktiske udgifter 2012: 240.000 DKK

Sekretariats- Statens Serum Institut, Danmark funktion

\section{4-4382-1 NIOM A/S - Nordisk Institutt for Odontologiske Materialer}

\begin{tabular}{|l|c|c|c|c|c|} 
Valuta & Budget 14 & Budget 13 & Budget 12 & Disp./bud. 12 & Bud.disp. af \\
\hline DKK & 10.456 .000 & 10.781 .000 & 10.590 .000 & $100 \%$ & NIOM AS
\end{tabular}

Formål

NIOM har til formål å sikre at medisintekniske produkter som benyttes innen tannpleien i Norden, oppfyller de helsemessige og tekniske krav som kan stilles med hensyn til utviklingen innen området. NIOMs oppgaver er forskning, materialprøving, standardisering og opplysningsvirksomhet. NIOMs forsknings- og informasjonsvirksomhet skal baseres på vitenskapelig grunn og være praktisk anvendelig i klinisk virksomhet. NIOMs aktiviteter skal ha en høy nordisk profil og bidra til nordisk nytte ved å skape en merverdi utover faglige samarbeidsresultater. NIOMs visjon er å bidra til at pasienter i nordiske land får sikre og velfungerende biomaterialer.

Prioriteringer i NIOM har utarbeidet en strategisk plan 2012-2016 med 2014 fire hovedmål:

- NIOM skal ha en høy nordisk profil 
- NIOM skal drive biomaterialforskning på internasjonalt nivå

- NIOMs oppdragsvirksomhet skal generere midler og kompetanse som kan styrke den øvrige virksomheten

- NIOM skal være en aktiv premissleverandør innen europeisk og internasjonal standardisering.

Ifølge planen skal følgende oppgaver prioriteres i 2014:

- NIOM skal etablere direkte kontakt med nordiske tannleger gjennom nyhetsbrev på hjemlandets språk og ved at NIOMs hjemmesider inneholder klinisk anvendelig informasjon om materialer og metoder

- NIOM skal utføre produkttesting i henhold til internasjonale standarder for nordiske myndigheter

- NIOMs forskning og arbeid innen standardisering skal øke pasientsikkerheten i Norden

- NIOM skal videreutvikle det nordiske forskningssamarbeidet gjennom økt fokus på kliniske problemstillinger

- NIOM skal tilby minst 24 måneder gjesteforskeraktivitet med forskere fra de nordiske landene.

Ledelse og Planlagte udgifter 2014: 2.500.000 NOK

adm.

Faktiske udgifter 2012: 2.456.025 NOK

Sekretariats- $\quad$ NIOM A/S

funktion

\section{Institutioner}

4-4380-3 Nordens Välfärdscenter (NVC)

\begin{tabular}{|l|c|c|c|c|c|} 
Valuta & Budget 14 & Budget 13 & Budget 12 & NMR fin. 12 & Bud.disp. af \\
\hline SEK & 24.301 .000 & 25.314 .000 & 25.076 .000 & $83 \%$ & Institutionen \\
\hline $\begin{array}{l}\text { Modsv. } \\
\text { DKK }\end{array}$ & 21.142 .000 & 21.264 .000 & 20.562 .000 & &
\end{tabular}

Formål

NVCs opgave er at fremme udviklingen inden for det velfærdspolitiske område i Norden og dets nærområder, 
samt at bidrage til at udvikle den nordiske velfærdsmodel i et globalt perspektiv. Dette skal ske gennem oplæring, information, fokus på forskningsarbejde og udbredelse af forskningsresultater, udviklingsarbejde, netværksopbyggende og internationalt arbejde. NVC er organiseret som tre organisatoriske enheder, men med én styrelse, som er ansvarlig for driften ved NVC Stockholm og centerets datterinstitutioner; NVC Finland og NVC Danmark. Alle institutionens virksomhedsformer og aktiviteter bidrager til den nordiske profil og nytte, således at arbejdet skaber en nordisk merværdi udover de rent fagmæssige samarbejdsresultater. MR-S/MR-SAM har besluttet at NVC Danmark skal sammenlægges med NVC Stockholm fra 1. januar 2015.

Prioriteringer i NVC arbejder med velfærdsmodellen som paraply for 2014 NVC's fem hovedindsatsområder:

- Velfærdspolitik: Hovedmålet er at belyse konsekvenser og udviklingsmuligheder for den nordiske velfærdsmodel. En hovedprioritering er at belyse hvordan det nordiske samfund er at vokse op i og blive gammelt i. Der igangsættes nordisk projekt og der sammenstilles analyser inden for familiepolitik og ældrepolitik.

- Funktionshinder: Formålet er at skabe forudsætning for ligestilling, deltagelse i samfundslivet og inkludering af personer med funktionsnedsættelse. Arbejdet tager udgangspunkt i FN konventionen om rettigheder for personer med funktionsnedsættelse og hvorledes denne er implementeret i de nordiske lande, blandt andet inden for arbejdsmarkedet. Der vil blive prioriteret samarbejde med brugerorganisationerne for at identificere specifikke indsatsområder.

- Alkohol- og narkotikaforskning: Målsætningen er at stimulere, opretholde og formidle en aktuel og relevant samfundspolitisk kundskabsbase på alkohol- og narkotikaområdet. NVC initierer, udfører og deltager i nordiske og internationale projekter på området, samt bidrager med underlag til nordiske politiske og administrative netværk.

- Velfærdsteknologi: Målsætningen er at fremme de 
nordiske landes udvikling og udbredelse af velfærdsteknologiske løsninger, således at landene effektiv kan drage nytte af hinandens erfaringer. Der fokuseres blandt andet på anvendelse af velfærdsteknologi som understøttelse af inkludering på arbejdsmarkedet af personer med funktionsnedsættelse.

- Arbejdsinkludering: Formålet er at sikre fortsat fokus på sårbare unges situation på arbejdsmarkedet. Specifik prioritering er projekt: Kundskabsbank om frafald i højere uddannelse samt inkludering på arbejdsmarkedet af unge med psykiske problemstillinger.

Generelt vil der være fokus på information og implementering i alle de nordiske lande samt de selvstyrende områder og Nordens nærområder af resultaterne af NVC's arbejde. Dette sker ved forskellige former for arrangementer for beslutningstagere, brugerorganisationer, medier med flere.

Kontrakt-

2012-2014

periode

Kontrakt- Opfyldt

status

Økonomi Ingen bemærkninger

Ledelse og Planlagte udgifter 2014: 8.500.000 SEK

adm. Faktiske udgifter 2012: 9.028.096 SEK

\section{4-4381-3 Nordiska högskolan för folkhälsovetenskap (NHV)*}

\begin{tabular}{|l|c|c|c|c|c|} 
Valuta & Budget 14 & Budget 13 & Budget 12 & NMR fin. 12 & Bud.disp. af \\
\hline SEK & 45.989 .000 & 45.592 .000 & 45.163 .000 & $84 \%$ & Institutionen \\
\hline $\begin{array}{l}\text { Modsv. } \\
\text { DKK }\end{array}$ & 40.010 .000 & 38.297 .000 & 37.034 .000 & & \\
\hline
\end{tabular}

* NHV er finansieret direkte af landene, og indgår derfor ikke i de akkumulerede beløb 
Formål

Ledelse og adm.
I 2013 besluttede EK-S at indstille til MR-S og MR-SAM at nedlægge Nordic School of Public Health NHV (NHV) med sigte på at skolen skal afvikles senest den 1 . januar 2015. I 2014 skal NHV's ledelse afvikle skolen og en organisationskomite udarbejde beslutningsgrundlag for de nordiske aktiviteter inden for folkesundhed. De nordiske lande ser det som yderst vigtigt at beholde ambitionsniveauet $\mathrm{i}$ det fortsatte nordiske samarbejde på folkesundhedsområdet.

Ved forhandlingerne mellem Nordisk Ministerråd og Nordisk Råd om budgettet for 2014 er der opnået enighed om:

-at der er behov for at fremme det internationale samarbejde om tiltag for at modvirke voksende antibakteriel resistens (One Health). Derfor foreslås det, at en fælles nordisk indsats på dette område prioriteres højt, når det kommende nordiske samarbejde omkring folkehelse skal udformes og besluttes i starten af 2014 som følge af afviklingen af Nordic School of Public Health (NHV).

Planlagte udgifter 2014: 8.600.000 SEK

Faktiske udgifter 2012: 8.532.145 SEK 


\section{Närings-, Energi och Regionalpolitik}

\section{Generel indledning}

Generelt

MR-NER skal på det erhvervspolitiske område først og fremmest sikre at fyrtårnsprojekterne under det nye samarbejdsprogram for 2014-2017 sættes i gang. Projekterne skal have fokus på at styrke den nordiske konkurrencekraft, herunder at skabe fælles viden, der kan styrke nordisk erhvervspolitik. Det gælder fx for områderne innovation i offentlige sektor, behovsdreven innovation og entreprenørskab. Samarbejdsprogrammet for Innovations- og erhvervspolitik 2014-17 er blevet udarbejdet i løbet af 2013. Der vil også blive lagt vægt på at få prioriteringsindsatsen om bio-økonomi sat i gang.

MR-NER skal, via sit energipolitiske samarbejdsprogram for 2014-2017, bidrage til grønne vækstsamfund med stabil energiforsyning og bæredygtig energi til gavn for velfærden i de nordiske lande. Det nordiske energisamarbejde skal være et redskab til yderligere harmonisering af det nordiske elmarked og markedsføring af nordiske styrkepositioner på den globale arena. Der skal fortsat arbejdes målrettet med velfungerende energimarkeder og klimavenlige energisystemer, energieffektivisering og brug af vedvarende energikilder samt med udviklingen af mere miljøvenlige energikilder til transport på sø, land og i fiskerisektoren.

Det nordiska regionalpolitiska samarbetet skall bidra till att säkra en implementering av de regionalpolitiska målsättningarna inom ministerrådet för näringsliv, energi och regionalpolitik (MR-NER). Regionalsektorn har tagit fram ett samarbetsprogram för perioden 2013 - 2016 som ska 1) Bidra till en regionalt hållbar välfärdsutveckling, 2) Främja en hållbar regional utveckling i Arktis, samt 3) Stimulera en grön tillväxt $i$ alla regioner. Regionalsektorn avser att under programperioden skapa en gemensam plattform för kunskapsuppbyggnad om de välfärdsutma- 
ningar de demografiska förändringarna bidrar till. Regionalsektorn avser att ta initiativ till en tematisk bred och djuplodande studie av den framtida utvecklingen i Arktis i form av scenarier eller framtidsbilder, samt bidra till en ökad grön tillväxt i näringsliv och ökad sysselsättning genom nya initiativ som ska främja grön innovation regionalt och lokalt.

Udmøntning af De samlede besparelse på MR-NER udgør 5,026 TDKK besparelse $i$ budget 2014 (inkl. de administrative besparelser), svarende til 3,9\% i henhold til budget 2013. Näring- og Energisektorene under MR-NER, har valgt at følge MR-SAM's anbefalinger i forhold til fordeling af besparelserne. Regionalsektoren har på baggrund af fordelingsnøglen særligt prioriteret at tage midler fra posten grænseregionalt samarbejde og dermed opretholde det ønskede finansieringsniveau på sektorens andre budgetposter.

Minister-
rådets
styrings-
dokumenter

- Nordisk samarbejdsprogram for innovation og erhvervspolitik 2014-2017

- Samarbejdsprogram for det nordiske energipolitiske samarbejde 2014-2017

- Nordisk regionalpolitisk samarbejdsprogram 2013-2016

Styringsdokumenterne er tilgængelige på www.norden.org

Resumé af

Ministerrådets resultater i 2012
- Rapporten Nordic Entreprenuership Review presenterades och visar att de nordiska länderna är goda till att igångsätta verksamheter men att det finns svårigheter när det gäller att få dem att växa.

- I forlængelse af fyrtårnsprojektet om innovation gennem offentligt indkøb og regulering, blev der i 2012 forberedt og fundet finansiering til tre projekter om at gennemføre innovative indkøb til sundhedssektoren i Norden. Projekterne finansieres af Nordisk Innovation i samarbejde med Tekes, VINNOVA, Innovation Norge, Erhvervsstyrelsen og Rannis for en samlet sum af ca. 10 mio. NOK. Projekterne gennemføres i 2013 
og 2014 af kommuner, hospitaler og leverandører til sundhedssektoren.

- Innovationsforum fremlagde anbefalinger til et nordisk arbejde med innovativt offentligt udbud og grønne forretningsmodeller. Anbefalingerne blev taget med $i$ arbejdet med det nye samarbejdsprogram 20142017.

- Nordic Built udarbejdede i 2012 sit charter på Nordic Built Arena med deltagelse fra 60 repræsentanter fra byggesektoren. Charteret er en beskrivelse af bæredygtige værdier og ambitioner for den nordiske byggesektor. På nuværende tidspunkt har mere end 120 virksomheder og institutioner underskrevet charteret og dermed forpligtet sig til dets principper.

- I energisektoren udarbejdede de nordiske systemoperatører i 2012 en plan for netinvesteringer og planer, der har et nordisk perspektiv og bygger på analyser af nordisk nytte.

- De nordiske systemoperatører fremlagde ligeledes en vurdering af indpasningen af de øgede mængder vind i det nordiske elnet. Vurderingen påviste, at integreringen stadig kan løses i de kommende år, men at der vil være behov for investeringer i elnettene og for øget forbrugerfleksibilitet i fremtiden, såfremt de stigende mængder vindkraft skal kunne håndteres. De nordiske regulatorer udtrykte $\mathrm{i}$ en rapport tilfredshed med fremdriften i etableringen af et fælles nordisk detailmarked for handel med elektricitet i 2015.

- I energisektoren blev der endvidere startet flere initiativer under Grøn Vækst i 2012, herunder Nordsyn, Testcentre og øget forbrugerfleksibilitet på elmarkedet. Projekterne skal i de næste år bidrage til at opfylde NMR's ambitioner indenfor Grøn Vækst. 
- Regionalsektorn har arbetat fram ett nytt regionalpolitiskt samarbetsprogram 2013 - 2016 som lades fram av de nordiska regionalministrarna.

- Regionalsektorn har under 2012 fortsatt sin satsning på de demografiutmaningar som de nordiska länderna står inför.

- Regionalsektorn har tagit fram en demografisk handbok för inspiration till handling i nordiska kommuner och regioner för att möta demografiska förändringar.

\begin{tabular}{llrrrr} 
& & Budget & Budget & \multicolumn{2}{c}{ Difference } \\
& & $\mathbf{2 0 1 4}$ & $\mathbf{2 0 1 3}$ & \multicolumn{1}{c}{+ - } & \multicolumn{1}{c}{$\mathbf{\%}$} \\
\hline Sum MR-NER (TDKK) & $\mathbf{1 2 5 . 5 0 0}$ & $\mathbf{1 2 7 . 6 9 4}$ & $\mathbf{- 2 . 1 9 4}$ & $\mathbf{- 1 , 7 \%}$ \\
& & & & \\
& Näring & 81.053 & 82.379 & -1.326 & $-1,6 \%$ \\
\hline \multirow{2}{*}{$4-5140-1$} & Projektmidler - Näring & 1.957 & 1.996 & -39 & $-2,0 \%$ \\
& Projektmidler Näring & 1.957 & 1.996 & -39 & $-2,0 \%$ \\
& Institutioner - Näring & 79.096 & 80.383 & -1.287 & $-1,6 \%$ \\
$4-5180-3$ & Nordisk Innovation & 79.096 & 80.383 & -1.287 & $-1,6 \%$ \\
& Energi & 11.163 & 11.453 & -290 & $-2,5 \%$ \\
\hline $4-5141-1$ & Projektmidler Energi & 4.192 & 2.220 & 1.972 & $88,8 \%$ \\
$4-5142-2$ & Arbejdsgrupper - energi & 0 & 2.077 & -2.077 & - \\
& Institutioner - Energi & 6.971 & 7.156 & -185 & $-2,6 \%$ \\
$4-3220-3$ & Nordisk Energiforskning (NEF) & 6.971 & 7.156 & -185 & $-2,6 \%$ \\
& Regional & 33.284 & 33.862 & -578 & $-1,7 \%$ \\
\hline $4-5143-1$ & Projektmidler Regional & 5.393 & 3.753 & 1.640 & $43,7 \%$ \\
$4-5151-4$ & NORA & 6.640 & 6.821 & -181 & $-2,7 \%$ \\
$4-5160-2$ & Grenseregionalt samarbeid & 9.550 & 11.809 & -2.259 & $-19,1 \%$ \\
& Institutioner - Regional & 11.701 & 11.479 & 222 & $1,9 \%$ \\
$4-6180-3$ & Nordregio & 11.701 & 11.479 & 222 & $1,9 \%$ \\
& & & & & \\
\hline Opdelt på kategorier & Projektmidler & 11.542 & 7.969 & $9,2 \%$ & $6,2 \%$ \\
\hline & Programlignende aktiviteter & 9.550 & 13.886 & $7,6 \%$ & $10,9 \%$ \\
& Institutioner & 97.768 & 99.018 & $77,9 \%$ & $77,5 \%$ \\
& Organisationsbidrag & 6.640 & 6.821 & $5,3 \%$ & $5,3 \%$ \\
& & & &
\end{tabular}




\section{Näring}

4-5140-1 Projektmedel - Näring

\begin{tabular}{|l|c|c|c|c|c|} 
Valuta & Budget 14 & Budget 13 & Budget 12 & Disp./bud. 12 & Bud.disp. af \\
\hline DKK & 1.957 .000 & 1.996 .000 & 2.077 .000 & $96 \%$ & EK-NER/N
\end{tabular}

Formål

Projektmidlerne skal bruges til at gennemføre de politiske målsætninger i ministerrådet (MR-NER). Først og fremmest skal projektmidlerne sikre at fyrtårnsprojekterne under det nye samarbejdsprogram kan sættes i gang. Projektmidlerne skal anvendes til projekter, som har fokus på at styrke den nordiske konkurrencekraft, herunder til at skabe fælles viden der kan styrke nordisk erhvervspolitik. Det gælder fx for områderne innovation i offentlige sektor, behovsdreven innovation og entreprenørskab.

Prioriteringer i Et nyt samarbejdsprogram for Innovations- og erhvervs2014 politik er blevet udarbejdet i løbet af 2013. Projektmidlerne skal anvendes til at sætte erhvervsministrenes fyrtårnsprojekter, i det nye samarbejdsprogram, i gang.

Endelig kan projektmidlerne anvendes til et mindre antal fokuserede satsninger, som fx en satsning på området for bio-økonomi som forventes højt prioriteret under det islandske formandskab.

\section{4-5180-3 Nordisk Innovation}

\begin{tabular}{|l|c|c|c|c|c|} 
Valuta & Budget 14 & Budget 13 & Budget 12 & NMR fin. 12 & Bud.disp. af \\
\hline NOK & 80.710 .000 & 82.023 .000 & 79.226 .000 & $61 \%$ & Institutionen \\
\hline $\begin{array}{l}\text { Modsv. } \\
\text { DKK }\end{array}$ & 79.096 .000 & 80.383 .000 & 76.469 .000 & &
\end{tabular}

Formål

Nordisk Innovation skall vara Nordiska Ministerrådets viktigaste organ för att genomföra ett nordiskt näringspolitiskt samarbete, med sikte på att utveckla och stärka det 
nordiska näringslivet som ett av de främsta och mest konkurrenskraftiga i världen.

Nordisk Innovations insatser skall medverka till en hållbar tillväxt, värdeskapande och ett mer konkurrenskraftigt, entreprenöriellt och innovativt näringsliv i Norden.

Målsättningen för Nordisk Innovation är att bidra till att skapa nordisk nytta genom aktiviteter som

- ökar nordisk kompetens och konkurrenskraft,

- manifesterar och utvecklar nordisk samhörighet,

- skulle kunna genomföras i nationell regi, men där påvisbara effekter kan uppnås genom gemensamma nordiska satsningar,

- förstärker gemensam politikutformning inom näringslivsområdet på nordisk nivå

Nordisk Innovation ska skapa nätverk och samarbetsplattformar mellan nordiska offentliga och privata aktörer inom handel, innovation och näringsfrämjande. Samarbetet ska stärka utvecklingen av Norden som en marknad och stärka nordiska företags synlighet och genomslagskraft på marknader utanför Norden. I tillæg til den årlige bevilling gives en tilsagnsfuldmagt på 70 MNOK. Denne fordeles med maksimalt 40 MNOK 2015, 20 MNOK i 2016 og 10 MNOK i 2017.

Prioriteringer i Nordisk Innovation skal fortsætte med at koncentrere 2014 arbejdet om få og større satsninger. Hoveddelen af Nordisk Innovations ressourcer skal benyttes til satsninger indenfor innovation, handelsfremme og grøn vækst.

Nordisk Innovation skal i 2014:

- Bistå Nordisk Ministerråd med medfinansiering og sekretariatsbistand af fyrtårnsprojekter under erhvervsministrenes samarbejdsprogram som dækker perioden 2014-2017.

- Bistå Nordisk Ministerråd med at udvikle et initiativ der kan styrke Nordens globale position indenfor bio-økonomi. 
- Bistå Nordisk Ministerråd ved at udvikle en erhvervsrettet indsats i relation til NordMin, samarbejdsministrenes satsning om bæredygtig mineog mineralindustri.

- Bistå Nordisk Ministerråd med gennemførelse af projekterne om udvikling af nordiske standarder for klimavenligt byggeri under samarbejdsministrenes satsning om grøn vækst.

- Bistå Nordisk Ministerråd med gennemførelsen af Nordic Built, en erhvervsrettet indsats om klimavenligt byggeri.

- Bistå Nordisk Ministerråd med opfølgning på Nordic Entrepreneurship Review.

- Videreudvikle arbejdet med at styrke det indre marked i Norden.

- Bistå Nordisk Ministerråd med udarbejdelse af maksimalt to mindre analyser af potentielle nye samarbejdsområder på opdrag af EK-N.

- I det øvrige gjennomføre satsinger prioritert av styret til Nordisk Innovation.

MR-NER tog beslutning om nyt samarbejdsprogram 2014-2017 i oktober 2013.

Ved forhandlingerne mellem Nordisk Ministerråd og Nordisk Råd om budgettet for 2014 er der opnået enighed om:

-at undersøge, om der findes mulige effektiviserings- og rationaliseringsgevinster ved at sammenlægge driftsfunktioner i de tre separate organisationer, der udgør Nordisk Center i Oslo. Styring af institutionerne udredes i generalsekretærens moderniserings-arbejde.

Kontrakt- 2014

periode

Kontrakt- Opfyldt

status

Økonomi Ingen bemærkninger 
Närings-, Energi och Regionalpolitik

Ledelse og Planlagte udgifter 2014: 5,9 MNOK

adm.

Faktiske udgifter 2012: 5,6 MNOK

\section{Energi}

\section{4-5141-1 Projektmedel - Energi}

\begin{tabular}{|l|c|c|c|c|c|} 
Valuta & Budget 14 & Budget 13 & Budget 12 & Disp./bud. 12 & Bud.disp. af \\
\hline DKK & 4.192 .000 & 2.220 .000 & 2.180 .000 & $93 \%$ & $\begin{array}{c}\text { EK- } \\
\text { NER/Energi }\end{array}$
\end{tabular}

Formål

Projektmidlerne skal sikre gennemførelsen af ministerrådets energipolitiske målsætninger. De energirelaterede klimaudfordringer står højt på dagsorden i ministerrådet. Det nordiske energisamarbejde skal målrettes disse udfordringer og bidrage til sikring af landenes forsyningssikkerhed samt skabe forudsætninger for grøn vækst. De nordiske lande skal være aktive og konstruktive medspillere i den politiske proces i EU og i andre internationale fora. Gennem samarbejdet skal landenes indflydelse på og implementering af EU-lovgivningen styrkes.

Prioriteringer i Vigtige områder for det energipolitiske samarbejde i Nor2014 den i 2014 vil være energieffektivisering, vedvarende energi og yderligere harmonisering af det nordiske elmarked, områder som alle er centrale for skabelsen af grøn vækst i Norden. I tillæg skal der fokuseres på tyndt befolkede områder og miljøvenlig energi til transport på sø og land samt i fiskerisektoren.

I 2013 udarbejdes et nyt handlingsprogram for det energipolitiske samarbejde 2014-2017.

I 2014 kan der derfor fremkomme prioriteringer i henhold til nyt handlingsprogram, som ikke er beskrevet hér.

- Vedvarende energi og energieffektivisering i transportsektoren samt i fiskeri og godstransport til søs

- $\quad$ get integration af vedvarende energi i energisy- 
stemerne og yderligere harmonisering af elmarkedet

- Energieffektivisering

- Energi i tyndt befolkede områder

- $\quad$ get indsats for udvikling af fornybardirektivets samarbejdsmekanismer

- Fortsat samarbejde omkring forberedelse og gennemføring af EU-strategier og direktiver på energiområdet.

- Evt. nye prioriteringer i overensstemmelse med det nye handlingsprogram for 2014-2017

På nuværende tidspunkt udføres en del af arbejdet under energisektoren af en række arbejdsgrupper. EK-E vil i forbindelse med udarbejdelsen af det nye handlingsprogram tage beslutning om den videre arbejdsfordeling.

\section{4-5142-2 Arbetsgrupper - Energi}

\begin{tabular}{|l|c|c|c|c|c|} 
Valuta & Budget 14 & Budget 13 & Budget 12 & Disp./bud. 12 & Bud.disp. af \\
\hline DKK & 0 & 2.077 .000 & 2.077 .000 & $85 \%$ & EK- \\
& & & & & NER/Energi
\end{tabular}

Formål

EK-E har besluttet at ligge denne budgetpost sammen med 4-5141-1Projektmidler Energi.

\section{4-3220-3 - Nordisk Energiforskning (NEF)}

\begin{tabular}{|l|c|c|c|c|c|} 
Valuta & Budget 14 & Budget 13 & Budget 12 & NMR fin. 12 & Bud.disp. af \\
\hline NOK & 7.113 .000 & 7.302 .000 & 6.114 .000 & $30 \%$ & Institutionen \\
\hline $\begin{array}{l}\text { Modsv. } \\
\text { DKK }\end{array}$ & 6.971 .000 & 7.156 .000 & 5.808 .000 & &
\end{tabular}

Formål

NEF bidrager til at øge nordisk kompetence og konkurrenceevne indenfor energisektoren. NEF arbejder for at 
udvikle en fælles retning for forskning, udvikling og information om de dele af energisektoren som har en fælles nordisk interesse og nytte.

Ved at være en aktiv medspiller i implementeringen af nationale strategier kan NEF bidrage til en øget internationalisering af energiforskningen. NEF vil fortsat videreudvikle sin rolle som trinbræt til EU-programmer for nordiske forskningsinitiativer.

NEF skal bidrage til videnskabsbaserede beslutningsgrundlag, koble FoU til relevante energipolitiske processer, og hjælpe med løsninger af aktuelle energipolitiske spørgsmål. Videre skal NEF være en aktør i det internationale energiforskningssamarbejde i forhold til det europæiske forskningsrum (ERA), International Energy Agency (IEA) og andre relevante internationale fora.

NEF skal fungere som brobygger mellem industri-, forsknings- og policyaktører.

Der udarbejdes på nuværende tidspunkt en evaluering af NEF. På baggrund af denne vil MR-NER på deres møde i oktober 2013 tage beslutning om en række anbefalinger til det fremtidige arbejde i NEF.

Prioriteringer i 2014
- Forvaltning af forskningsprojekterne under Sustainable Energy Systems og Topforskningsinitiativet

- Forvaltning af Northern European Innovative Energy Research Programme (N-INNER)

- Understøtte aktiviteter indenfor forskning og udvikling gennem finansiering af af FoU-projekter, netværk og mobilitet, samt seminarer og konferencer

- Profilering af det nordiske energisamarbejde i nordiske forsknings- og innovationsmiljøer, samt relevante internationale fora

- Kommunikation og formidling

Ved forhandlingerne mellem Nordisk Ministerråd og Nordisk Råd om budgettet for 2014 er der opnået enighed om:

-at undersøge, om der findes mulige effektiviserings- og 
rationaliseringsgevinster ved at sammenlægge driftsfunktioner i de tre separate organisationer, der udgør Nordisk Center i Oslo. Styring af institutionerne udredes i generalsekretærens moderniserings-arbejde.

-at transport skal inngå i det nye energipolitiske handlingsprogrammet $(2014$ - 2017). Forskning og innovasjon på transportområdet skal også vurderes i forbindelse med utarbeidingen av nytt energiforskningsprogram (2015 2018) for Nordisk energiforskning.

Kontrakt- 2011-2014

periode

Kontrakt- Opfyldt

status

Økonomi Ingen bemærkninger

Ledelse og Planlagte udgifter 2014: 5,0 MNOK

adm.

Faktiske udgifter: 2012: 5.024 TNOK

\section{Regional}

4-5143-1 Implementering av samarbetsprogram, demografi, arbetsgrupper och projektmedel - Regional

\begin{tabular}{|l|c|c|c|c|c|} 
Valuta & Budget 14 & Budget 13 & Budget 12 & Disp./bud. 12 & Bud.disp. af \\
\hline DKK & 5.393 .000 & 3.753 .000 & 3.447 .000 & $83 \%$ & EK-R
\end{tabular}

Formål Regional utveckling, både inom Norden och EU, är en viktig motor för att säkra tillväxt och välfärd i de nordiska länderna. Regionalpolitikens fokus på den territoriella dimensionen av samhällsutvecklingen ger den en särskild roll som strategisk och tematisk brobyggare mellan politikområden och sektorsintressen.

De nordiska regionalpolitiska medlen skall bidra till att säkra en implementering av de regionalpolitiska målsättningarna inom ministerrådet för näringsliv, energi och 
regionalpolitik (MR-NER). Ämbetsmannakommittén för regionalpolitik (ÄK-R) har det överordnade ansvaret för regionalsektorns aktiviteter och skall vara ett centrum för strategiska politiska diskussioner och erfarenhetsutbyte kring policyutveckling inom de nordiska länderna.

För att genomföra det nordiska regionalpolitiska samarbetet har regionalsektorn tagit fram ett samarbetsprogram för perioden 2013 - 2016 som ska 1) Bidra till en regionalt hållbar välfärdsutveckling, 2) Främja en hållbar regional utveckling i Arktis, samt 3) Stimulera en grön tillväxt $\mathrm{i}$ alla regioner.

Regionalsektorn avser att under programperioden skapa en gemensam plattform för kunskapsuppbyggnad om de välfärdsutmaningar de demografiska förändringarna bidrar till. Den demografiska utvecklingen i de nordiska länderna innebär stora utmaningar för regioner och kommuner i form av efterfrågan och upprätthållande av tjänsteutbud och offentlig service, infrastruktur, kompetensförsörjning, tillgång till bostäder, näringslivsutveckling, etc.

Regionalsektorn avser att ta initiativ till en tematisk bred och djuplodande studie av den framtida utvecklingen i Arktis i form av scenarier eller framtidsbilder.

Sektorn skall bidra till en ökad grön tillväxt i näringsliv och ökad sysselsättning genom nya initiativ som ska främja grön innovation regionalt och lokalt. Exempel på hållbar stadsutveckling som kan fungera som modell för olika regioner i de nordiska länderna och Europa skall utvecklas under programperioden.

ÄK-R har initierat fyra arbetsgrupper för att genomföra intentionerna i samarbetsprogrammet som ska arbeta utifrån teman; 1) Välfärd/demografi, 2) Arktis, 3) Grön tillväxt - innovation, 4) Grön tillväxt - plansamarbete och hållbara stadsregioner. För detta ändamål överförs regionalsektorns projektmedel från budgetpost 4-5145-2 
Arbetsgrupper under Regional till budgetpost 4-5143-1 för arbetsgruppernas arbete med implementering av programmet. Den tidigare arbetsgruppen för EU/Interreg/Statstöds-frågor fortsätter som nätverk.

Regionalsektorn avser att under året ta initiativ till insatser för ett stärkt nordiskt näringsliv genom att maximera hållbart, ekonomiskt och socialt utnyttjande av biologiska resurser från land och hav och härigenom stärka regional utveckling. Bioekonomi har blivit en allt viktigare del av den nationella, nordiska och globala politiken. De sociala, ekonomiska och biologiska utmaningarna i kombination med bristen på naturresurser och klimatförändringar kräver en ny syn på kunskap och innovation samt en anpassad kunskapsbaserad politik. En ökad satsning på forskning och innovation ur ett regionalt perspektiv kan bidra till nya och smartare produkter som bromsar klimatförändringarna och bidrar till ny sysselsättning.

Prioriteringer $\mathrm{i}$

2014
- Bidra till en regionalt hållbar välfärds- och demografiutveckling,

- Främja en hållbar regional utveckling i Arktis,

- Stimulera en grön tillväxt i alla regioner

- Stärka nordiskt näringsliv genom att maximera hållbart, ekonomiskt och socialt utnyttjande av biologiska resurser från land och hav för en regional utveckling

\section{4-5145-2 Arbetsgrupper under Regional}

\begin{tabular}{|l|c|c|c|c|c|} 
Valuta & Budget 14 & Budget 13 & Budget 12 & Disp./bud. 12 & Bud.disp. af \\
\hline DKK & 0 & 0 & 1.527 .000 & $100 \%$ & EK-R
\end{tabular}

Formål

Budgetposten är sammanslagen med budgetpost 4-5143-1 Implementering av samarbetsprogram, demografi, arbetsgrupper och projektmedel - Regional. 


\section{4-5151-4 NORA}

\begin{tabular}{|l|c|c|c|c|c|} 
Valuta & Budget 14 & Budget 13 & Budget 12 & Disp./bud. 12 & Bud.disp. af \\
\hline DKK & 6.640 .000 & 6.821 .000 & 6.505 .000 & $100 \%$ & MR- \\
& & & & & NER/ER-R
\end{tabular}

Formål

NORA skall stärka och utveckla samarbetet i den nordatlantiska regionen (Grönland, Island, Färöarna och KustNorge) och med nordens grannar i väst (Kanada, Skottland och Irland). Genom ett stärkt samarbete mellan näringsliv och forsknings- och utvecklingsorganisationer över nationsgränser skall NORA bidra till att göra nordatlanten till en kraftfull nordisk region med en stark och hållbar ekonomisk utveckling. NORA skall fungera som en strategisk aktör och pådrivare i de nordatlantiska ländernas projektsamarbete.

Prioriteringer i NORA skall fortsätta genomförandet av sitt strategipro2014 gram 2012 - 2016 för att:

- Stärka innovation och samarbete inom fiskeri och marina resurser,

- Främja differentieringen av regionens ekonomier för att skapa nya möjligheter,

- Utveckla lösningar på geografiska utmaningar i regionen

NORA skall genom konkreta initiativ omsätta handlingsplanen för 2014 med fokus på att:

- förmedla och initiera konkreta projektsamarbeten i regionen,

- utveckla en attraktiv plattform för nordiskt samarbete med grannländerna,

- skapa arenor där gemensamma strategier och initiativ för nordatlantiska problemställningar kan utvecklas,

- bidra i realiseringen av det regionalpolitiska sam- 
arbetsprogrammets mål om att stärka en hållbar näringslivsutveckling i Arktis

- fortsätta utveckla samarbetet med Kanada, Skottland och Irland

\section{4-5160-2 Gränsregionalt samarbete}

\begin{tabular}{|l|c|c|c|c|c|} 
Valuta & Budget 14 & Budget 13 & Budget 12 & Disp./bud. 12 & Bud.disp. af \\
\hline DKK & 9.550 .000 & 11.809 .000 & 10.529 .000 & $97 \%$ & EK-R
\end{tabular}

Formål

Medlen för gränsregionalt samarbete skall följa de övergripande prioriteringarna i det nordiska regionalpolitiska samarbetsprogrammet 2013 - 2016. De nordiska medlen till det gränsregionala samarbetet skall bidra till att reducera gränshinder och att utveckla hållbara gränsregioner och regionalsektorn kommer under året att systematiskt arbeta för en gemensam kunskapsutveckling och erfarenhetsutbyte.

De avsatta medel (1,8 miljoner DKK) för utveckling och förvaltningen av den nordiska statistikdatabasen StatNord har återförts till budgetpost 4-5143-1 Implementering av samarbetsprogram, demografi, arbetsgrupper och projektmedel - Regional eftersom projektet inte igångsatts.

Prioriteringer i Det nordiska finansiella bidraget till det nordiska gräns2014 regionala samarbetet skall under 2014 bidra till ett välfungerande och fruktbart gränsregionalt samarbete.

\section{4-6180-3 Nordregio}

\begin{tabular}{|l|c|c|c|c|c|} 
Valuta & Budget 14 & Budget 13 & Budget 12 & NMR fin. 12 & Bud.disp. af \\
\hline SEK & 13.449 .000 & 13.665 .000 & 13.326 .000 & $59 \%$ & Institutionen \\
\hline $\begin{array}{l}\text { Modsv. } \\
\text { DKK }\end{array}$ & 11.701 .000 & 11.479 .000 & 10.927 .000 & &
\end{tabular}


Nordregio är Nordiska ministerrådets viktigaste organ för att genomföra och driva ett nordiskt regionalpolitiskt samarbete framåt, med sikte på att utveckla och stärka en hållbar utveckling i de nordiska regionerna.

Nordregio skall genom riktade forskningsinsatser medverka till en hållbar tillväxt och ett mer konkurrenskraftigt, innovativt regionalt Norden.

Målsättningen för Nordregio är att:

- öka nordisk kompetens och konkurrenskraft,

- fungera som förmedlare mellan forskning och politikutveckling

- bidra till att utveckla ny kunskap och kompetens i förhållande till strategiskt viktiga frågor om regional och lokal utveckling och planläggning

- fungera som kunskapsbor mellan Norden och Europa i förhållande till forskning och politikutveckling

- medverka till att tydliggöra nordiska intressen i EU-samarbetet genom förmedling av goda nordiska exempel

Nordregio skall genom sin forskning bidra till genomförande av det nordiska regionalpolitiska samarbetsprogrammet 2013 - 2016 och de löpande ordförandeskapsprogrammen. Nordregios sekretariatsfunktion för de fyra arbetsgrupper som Ämbetsmannakommittén för regionalpolitik nedsatt för genomförandet av sammanbetsprogrammet skall fortsätta.

Prioriteringer i 2014
- Producera en regional översikt "state-of-theregion" som analyserar de viktigaste utvecklingstendenserna

- Producera nödvändigt data- och kartmaterial för demografisatsningen

- Starta ett nytt större projekt om potentialer och attraktivitet i glest befolkade områden

- Bidra med ökad kunskap om kön, etnicitet och entreprenörskap i ett regionalt perspektiv

- Utveckla en värderingsmodell för regionala skill- 
nader i gröna växtstrategier

- Bidra till förståelsen av de processer som leder till ökad territoriell integration

- Starta ett nytt större samhällsvetenskapligt forskningsprojekt om Arktis

- Bidra till utveckling av metoder och strategier som främjar lokal och regional attraktivitet

Kontrakt- $\quad 2013-2015$

periode

Kontrakt- Uppfyllt

status

Økonomi Inga bemärkningar

Ledelse og Planlagte udgifter 2014: 4600 000 SEK

adm. Faktiske udgifter 2012: 4716940 SEK (ca 4100 tusen

DKK växelkurs 1,15) 


\section{Miljö}

\section{Generel indledning}

Generelt Det nordiska miljösamarbetet skall bidra till att bevara och förbättra miljökvalitet och livskvalitet i Norden, ha förvaltningsrelevans samt påverka det internationella samarbetet. Miljöhandlingsprogrammet för perioden 2013 2018, är det viktigaste styrdokumentet och utgångspunkten för miljösamarbetet.

Huvudteman i miljöhandlingsprogrammet är grön samhällsutveckling, klimatförändringar och luftföroreningar, biologisk mångfald och ekosystem samt hälsa och miljöfarliga kemikalier.

Norden och de nordiska ländernas miljösamarbete är i fokus och blir understött först och främst genom miljöarbetsgrupperna men också genom miljöfinansieringsbolaget NEFCO och miljömärket Svanen. Internationellt prioriteras samarbetet med regionala organ, t.ex. Arktiskt Råd, Barentsrådet och HELCOM (Helsinki Commission), men också i EU och i internationella miljökonventioner och t.ex. i FNs miljöprogram UNEP.

Tvärfackligt samarbete sker där det främjar integrering av miljöhänsyn i andra sektorer och där man uppnår strategiska synergier.

Nordiska ministerrådet finansierar Nordiska rådets miljöpris.

Udmøntning af Samarbetsministrarna har beslutat att minska nordiska besparelse i ministerrådets budget för 2014 med $5 \%$ varav 4 miljoner budget 2014 på administration och $3,5 \%$ på sektorbudgeterna. För miljösektorn blir det totalt 1696000 DKK varav 107000 DKK på administration. För miljösektorn reduceras arbetsgruppernas budget med 848000 DKK och NMRbidraget till NEFCO med 848000 DKK. De administra- 
Ministerrådets styringsdokumenter

Resumé af Ministerrådets resultater i 2012 tiva besparingarna ligger framförallt $\mathrm{i}$ arbetsgrupperna.

Målsättningar och prioriteringar finns i miljøhandlingsprogrammet som i tillägg till huvudtemana bland annat hållbar konsumtion och produktion, resurseffektivitet och avfall, kortlivade klimatföroreningar, friluftsliv, landskap och kulturmiljö, biologisk mångfald och klimatförändringar, havsmiljö och havsförsurning.

Några exempel på aktiviteter och resultat med stor synlighet i 2012:

- Klimat: samspelet mellan klimat och luftföroreningar t.ex. projekt och workshop om kortlivade klimatföroreningar (SLCP/Short Lived Climate Pollutants), projekt om reducering av klimatutsläpp i sektorer, Peru om avfall och Vietnam om cement inom ramen för Nordic Partnership Initiative

- Luft: utveckling av modellscenarier som grundlag för strategier och policybeslut bland annat med deltagande av Ryssland, projekt relaterade till Arktis och EU och FN:s luftvårdskonvention LRTAP (Long Range Transboundary Air Pollution)

- Havet: underlag till de regionala havsmiljökonventionerna särskilt HELCOM (Helsingforskommissionen) och Arktiska rådet särskilt AMAP (Arctic Monitoiring and Assessment Programme) om miljöfarliga ämnen och projekt relaterade till vattenramdirektivet och övergödning samt aktiviteter avseende havsmiljöplanering

- Biodiversitet och ekosystemtjänster: workshop om ekosystemtjänster i skog, projekt om restaurering av våtmarker, projekt i Barentsregionen om klimatförändringarnas påverkan på biologisk mångfald med deltagande av Ryssland, värdering av ekosystemtjänster inom ramen för arbete om TEEB (The Economics of Ecosystems and Biodiversity)

- Hållbar konsumtion och produktion: underlag till eko- 
designdirektivet, workshops och projekt om Svanen med utblick år 2015, bästa teknologi i biobränslehantering samt projekt kopplat till grön växt om grön offentlig upphandling

- Kemikalier: projekt och workshop om REACH, projekt om ämnen som har hög påverkan på reproduktionsförmågan samt om hormonförstörande ämnen och växtskyddsmedel, framtagning av testmetoder till OECD

- Avfall: projekt relaterade till avfallsdirektivet och främjandet av synergier mellan kemikalie-, produkt- och avfallspolitik, aktiviteter om matavfall, kostnadsnyttoanalys av ett nordiskt pantsystem samt projekt kopplat till grön växt om textil- och plastavfall

- Miljöekonomi: nordiskt samarbete om miljöteknologi, ekonomiska effekter av gröna jobb, mål och räkenskaper för en hållbar utveckling, värdering av utsläpp för fartygstrafik, värdering av naturkapital samt andra projekt relaterade till grön växt.

\begin{tabular}{|c|c|c|c|c|c|}
\hline & \multirow{2}{*}{$\begin{array}{c}\text { Budget } \\
2014\end{array}$} & \multirow{2}{*}{$\begin{array}{c}\text { Budget } \\
2013\end{array}$} & \multicolumn{2}{|c|}{ Difference } \\
\hline & & & & $+/-$ & $\%$ \\
\hline \multicolumn{2}{|c|}{ MR-Miljø (TDKK) } & 44.392 & 45.389 & -997 & $-2,2 \%$ \\
\hline $3-3310-1$ & Dispositionsmidler - Miljø & 6.247 & 6.149 & 98 & $1,6 \%$ \\
\hline $3-3311-2$ & Miljøsektorens arbejdsgrupper & 22.711 & 23.201 & -490 & $-2,1 \%$ \\
\hline $3-3320-2$ & NEFCOS Miljøudviklingsfond & 11.297 & 11.967 & -670 & $-5,6 \%$ \\
\hline $3-6720-4$ & SVANEN - Nordisk miljömärkning & 4.137 & 4.072 & 65 & $1,6 \%$ \\
\hline \multicolumn{2}{|c|}{ Opdelt på kategorier } & 44.392 & 45.389 & $100 \%$ & $100 \%$ \\
\hline & Projektmidler & 6.247 & 6.149 & $14,1 \%$ & $13,5 \%$ \\
\hline & Programlignende aktiviteter & 34.008 & 35.168 & $76,6 \%$ & $77,5 \%$ \\
\hline & Organisationsbidrag & 4.137 & 4.072 & $9,3 \%$ & $9,0 \%$ \\
\hline
\end{tabular}




\section{3-3310-1 Dispositionsmedel - Miljö}

\begin{tabular}{|l|c|c|c|c|c|} 
Valuta & Budget 14 & Budget 13 & Budget 12 & Disp./bud. 12 & Bud.disp. af \\
\hline DKK & 6.247 .000 & 6.149 .000 & 6.749 .000 & $90 \%$ & EK-M/MR-M
\end{tabular}

Formål

Miljösektorn förfogar över ett så kallat prioriteringskonto som ska användas till politiska initiativ under budgetåret. Denna budgetpost används också i finansiering av Nordiska rådets miljöpris.

Prioriteringer i Prioriteringarna finns angivna i miljöhandlingsprogram2014 met men omfattar också prioriteringar i Islands ordförandeskapsprogram för miljösektorn 2014. Särskilt politiskt prioriterade teman under år 2014 förväntas vara:

- Bioekonomi

- Klimat

- Hav

- Ekosystemtjänster

3-3311-2 Miljösektorns arbetsgrupper

\begin{tabular}{|l|c|c|c|c|c|} 
Valuta & Budget 14 & Budget 13 & Budget 12 & Disp./bud. 12 & Bud.disp. af \\
\hline DKK & 22.711 .000 & 23.201 .000 & 23.501 .000 & $100 \%$ & $\begin{array}{c}\text { Arbetsgrup- } \\
\text { perna }\end{array}$
\end{tabular}

Formål Genomförandet av miljöhandlingsprogrammet sker genom arbetsgrupper i projekt och aktiviteter, i form av t.ex. analyser och utredningar, seminarer och workshops, och under medverkan av nordiska experter.

ÄK-M fördelar medlen till arbetsgrupperna.

Prioriteringer i Prioriteringarna finns angivna i miljöhandlingsprogram2014 met. Exempel på områden och aktiviteter som förväntas prioriterat i 2014 är: 
- Fortsatta aktiviteter inom ramen för grön ekonomi, härunder ekosystemtjänster, miljö- och hållbarhetsaspekter i räkenskaper, ekonomiska styrmedel och miljömärkning

- Ekosystembaserad förvaltning av hav- och kustområden

- Resurseffektivitet och forebyggelse av affald

- Fortsatt fokus på uppföljning av HELCOM:s handlingsplan för Östersjön

- Fortsatt engagement i det arktiska samarbetet

Ved forhandlingerne mellem Nordisk Ministerråd og Nordisk Råd om budgettet for 2014 er der opnået enighed om:

-at holdbare forbrukerpolitiske aspekter tydeliggjøres i det nye arbeidsprogrammet for miljøsektorens arbeidsgruppe - Holbar konsumtion och produksjon - HKP. -at der innen for budsjettposten "miljøsektorens arbeidsgrupper" (3-3311-2) øresmerkes midler til å fremme implementeringen af HELCOMs aksjonsplan (BSPA).

Ledelse og Arbetsgruppernas sekretariatskostnader förväntas ligga på adm. samma nivå som 2013 men styrningen av arbestgrupperna kommer att förbättras och den administrativa effektiviteten öka.

Sekretariats- Varje arbetsgrupp har en fast anställd koordinator som är funktion placerad i forvaltnin gsorganen i de nordiska ländernas administrationer.

\section{3-3320-2 NEFCOS Miljöutvecklingsfond}

\begin{tabular}{|l|c|c|c|c|c|} 
Valuta & Budget 14 & Budget 13 & Budget 12 & Disp./bud. 12 & Bud.disp. af \\
\hline DKK & 11.297 .000 & 11.967 .000 & 11.755 .000 & $100 \%$ & NEFCO
\end{tabular}

Formål

NEFCO:s egna medel och förvaltade medel uppgår sammanlagt till cirka 500 miljoner EUR. Nordiska minister- 
rådet bidrar med medel direkt till Nordiska miljöutvecklingsfonden (NMF) och indirekt via NMF till NMF Krediter och till Barents Hot-Spots Facility (BHSF). Sedan 1995 har NMR tillsammans med de nordiska länderna och NEFCO bidragit med sammanlagt ca 70 miljoner EUR till fonderna, totalt har projekt för 60 miljoner EUR godkänts. I dagsläget uppgår kapitalet i dessa tre fonder till ca 52 miljoner EUR. Den största fonden är NMF Krediter (30 miljoner EUR) som är en revolverande ordning där medel ändvänds flera gånger genom att medel ges som krediter eller garantier.

Miljøudviklingsfonden er rettet mod at muliggøre og tilrettelægge finansiering af miljøforbedrende foranstaltninger i Rusland, Ukraine, Vitryssland och Moldavien, på særligt favorable vilkår med sigte på at styrke forudsætningerne for gennemførelse af nye miljøprojekter.

Til orientering skal det nævnes, at Nordiska Projektexportfonden(NOPEF) fra 1. januar 2014 vil blive en selvstændig trust fund under NEFCO. Således vil Nordiska ministerrådet fremover bidrage med midler til to fonde under NEFCO.

\section{Ny programperiod $2014-2016$}

Miljöministrarna stödjer fortsatt nationell påfyllnad i NMF för perioden 2014 - 2016 samt fortsatt NMRbidrag. NMR-bidraget är nedjusterat med 848000 DKK, i linje med MR-SAM:s beslut om minskning av den nordiska budgeten och enligt beslut i ÄK-M.

\section{Administrativa kostnaderna för NMF}

De administrativa kostnaderna för fonderna är en av NEFCO:s styrelse fastslagen avgift på 1,75 \% av kapitalet per år (kostnadsstorleken är den samma som för de övriga motsvarande fonder som NEFCO förvaltar).

För år 2012 uppgick den administrativa kostnaden för de tre fonderna till 900000 EUR. Nettot till fonderna blev 
dock ett tillskott med 1 miljoner EUR, då NEFCO under 2012 betalade in ländernas bidrag till NMF på 1,92 miljoner EUR (totalt har NEFCO betalat in 5,75 miljoner EUR till NMF för åren 2011-2013).

\section{Framtida administrativa kostnader}

För att minska på de administrativa kostnaderna, speciellt för fonden NMF Krediter, har NEFCO överfört en stor del av arbetet till de lokala kontoren. Det bör dock noteras att det finns en förväntan om att öka antalet projekt främst inom de revolverande fonderna vilket däremot medför ökade administrativa kostnader.

Det bör även noteras att en reduktion av de administrativa kostnaderna inte påverkar NMR:s budget. NMR:s budget påverkas endast av de årliga anslagen till NMF.

Prioriteringer i NEFCO:s miljöutvecklingsfond ska i 2014 fokusera 2014 främst på följande:

- Renare produktionsprojekt i den privata sektorn

- Energibesparingsprojekt i den offentliga sektorn

- Regionala miljöprogram: eliminering av Barents Hot Spots

- Reduktion av miljögifter med fokus på Arktis

- Projekt för att minska utsläpp från jordbruket bland annat gödselhantering

- Projektutveckling

Ledelse og NEFCO

adm.

Sekretariats- NEFCO

funktion 


\section{3-6720-4 SVANEN - Nordisk Miljömärkning}

\begin{tabular}{|l|c|c|c|c|c|} 
Valuta & Budget 14 & Budget 13 & Budget 12 & Disp./bud. 12 & Bud.disp. af \\
\hline DKK & 4.137 .000 & 4.072 .000 & 2.581 .000 & $100 \%$ & $\begin{array}{c}\text { Nordiska } \\
\text { miljömärk- } \\
\text { ningsnämn- } \\
\text { den }\end{array}$
\end{tabular}

Formål

Svanen är Nordens officiella miljömärkning. Syftet är att ha en frivillig gemensam nordisk miljömärkning, som medverkar till att minska den börda som den dagliga konsumtionen lägger på miljön. Svanemärket granskar varors och tjänsters miljöpåverkan under hela livscykeln från råvara till avfall. Det ställs hårda miljö- och klimatkrav men även krav på funktion, hälsa och kvalitet.

Arbetet samordnas genom den Nordiska miljömärkningsnämnden (NMN), som bestämmer vilka produktgrupper som ska omfattas av Svanen och vilka krav de ska uppfylla. Nordiska experter arbetar fram förslag till kriterier och de olika ländernas miljömärkningssekretariat tar hand om licensansökningar och utfärdar licenser. Miljömärkningen i Norden omsätter årligen i storleksordningen 95 miljoner danska kronor och arbetsstyrkan utgör totalt 125 personer. Alla miljömärkningssekretariat arbetar parallellt med Svanen och det europeiska miljömärket EU Ecolabel.

Arbetet med att etablera en ny samnordisk juridisk plattform för Nordisk miljömärkning, i form av en förening med hemvist i Sverige, förväntas vara fungerande i 2014. Detta beslut har inga konsekvenser för budgeten.

\section{Administrativa kostnader för NMN}

Nordiska miljömärkningsnämnden är sekretariatet för den nordiska samordningen av Svanen och de administrativa kostnaderna ligger på drygt 3000000 NOK per år. I denna samordning kan dubbelarbete reduceras och specialuppdrag placeras där kompetansen är högst vilket utgör det rådrum för administrativ effektivisering som finns 
i NMN. Ett exempel på detta är nordisk IT-utveckling med etablering av en gemensam nordisk IT-plattform och intranät.

\section{Framtida administrativa kostnader}

Informationsarbete samt licensieringsarbetet ska förstärkas och effektiviseras vilket kan minska de administrativa kostnaderna.

Prioriteringer i Nordiska miljömärkningsnämnden ska i 2014 fokusera på 2014 följande:

- Implementering och uppföljning av visionsarbetet Svanen 2015 enligt MR-M beslutet, genom att definiera och genomföra de åtgärder som NMN utpekas vara ansvarig för

- Implementering av Strategiske mål for Nordisk miljømerking 2012 - 2015 och uppstart av arbetet med strategi för 2016-2020

- Förstärkning och effektivisering av det samnordiska kriterieutvecklingsarbetet

- Nordisk samordning av administrations- och informationsarbetet, speciellt licensieringsverksamheten

- Utveckling av nya stödkoncept för att upprätthålla och stimulera till ökad efterfrågan av Svanen bland producenter och konsumenter

- Samarbetet med Global Ecolabelling Network

Ledelse og Nordiska miljömärkningsnämnden adm.

Sekretariats- Nordiska miljömärkningsnämnden funktion 


\section{Arbejdslivspolitik}

\section{Generel indledning}

Generelt Ministerrådet for Arbejdsliv (MR-A) vil i perioden 201316 fokusere det nordiske regeringssamarbejde på de udfordringer, som udspringer af globaliseringen og den demografiske udvikling. Samtidig vil samarbejdet efter behov prioritere også mere konjunkturelt betingede udfordringer, som opstår i perioden.

MR-A har det overordnede ansvar for samarbejdet på arbejdslivsområdet. Samarbejdet organiseres af Embedsmandskomiteen for arbejdsliv (EK-A), som udstikker retningslinjer for og fordeler MR-A's budget.

Udmøntning af Den af MR-SAM besluttede generelle besparelse på sekbesparelse i torerne på 3,5 \% udmøntes gennem en reduktion af probudget 2014 jektmidlerne til de faste udvalg på arbejdslivsområdet med 9,1\% i henhold til budget 2013 .

Den af MR-SAM besluttede besparelse på de administrative udgifter på $0,3 \%$ udmøntes gennem en reduktion af bevillingen til NIVA på 1,4 \% i henhold til bevillingen 2013.

Minister-

Det overordnede formål med MR-As samarbejdsprogram rådets 2013-16 er at bidrage til at sikre et velfungerende nordisk styringsarbejdsmarked og et godt arbejdsliv $i$ et konkurrencedygdokumenter tigt Norden. De vigtigste mål er følgende:

På beskæftigelses- og arbejdsmarkedsområdet:

1. Mobilisere så stor en del af de interne arbejdskraftressourcer som muligt

2. Styrke matchningen af udbud og efterspørgsel på arbejdskraft

3. Fremme livslang læring målrettet arbejdsmarkedets behov

4. Fremme tiltrækningskraften i forhold til efterspurgt 
udenlandsk arbejdskraft fra lande uden for EU/EØS

5. Fremme koordinationen blandt relevante myndigheder

6 . Bekæmpe ledigheden blandt udsatte grupper og langtidsledighed

På arbejdsmiljø- og arbejdsretsområdet:

7. Styrke et godt fysisk og psykisk arbejdsmiljø på arbejdspladserne

8. Videreudvikle arbejdsmiljøstrategier og -tilsyn

9. Modvirke uacceptable arbejdsforhold, 'social dumping' og diskrimination på arbejdsmarkedet

10. Synliggøre betydningen af god ledelse og aktiv medarbejderindflydelse

11. Styrke en bæredygtig anvendelse af den enkelte arbejdstagers ressourcer

12. Sikre en god balance mellem lønmodtagerbeskyttelse og fleksibilitet

13. Fremme ligestilling og ligebehandling på arbejdsmarkedet

14. Styrke det nordiske samarbejde i forhold til international regulering

Tværgående prioritetsområder:

15. Forebygge og nedbryde grænsehindringer

16. Deltage i tværsektorielt samarbejde, hvor det giver nordisk nytte

Samarbejdet vil blive nærmere konkretiseret gennem det islandske formandskabsprogram for arbejdslivsområdet, de faste udvalgs virksomhedsplaner for 2014 samt kontrakterne med NIVA (2012-2014), Nordjobb (2014-16) og Informationsprogrammet (2013-2014).

Resumé af $\quad$ MR-A gennemførte et meget vellykket møde på Svalbard Ministeri september 2012. Fokus var på flere temadrøftelser med rådets resultater i 2012 arbejdsmarkedets parter på nordisk plan om centrale udfordringer samt på grænsehindringssamarbejdet: 
1. Muligheder og udfordringer for den nordiske velfærdsstat i et europæisk perspektiv, herunder som følge af den øgede arbejdskraftmobilitet i Europa.

2. Status og tiltag i forhold til ungdomsarbejdsløsheden i de nordiske lande.

3. Kvinder og erhvervsdeltagelse med særlig fokus på deltid og sygefravær.

På hvert af disse områder traf MR-A sammen med parterne en række beslutninger med henblik på opfølgning på drøftelserne.

MR-A anmodede desuden EK-A om at sikre konkret opfølgning på den kortlægning og analyse af en række grænsehindringer på arbejdsmarkeds- og socialområdet, som en ekspertgruppe nedsat af EK-A og EK-S havde afleveret i marts 2012.

MR-A godkendte også MR-As samarbejdsprogram for 2013-16 i skriftlig procedure i september 2012.

EK-A gennemførte to møder i 2012. EK-A's forårsmøde fokuserede på grænsehindringsekspertgruppens rapport, MR-As samarbejdsprogram og de to globaliseringsprojekter, som MR-A har hovedansvar for. EK-As efterårsmøde fokuserede på opfølgningen på MR-A's møde på Svalbard.

De tre faste udvalg under EK-A fortsatte deres arbejde med gensidig orientering om de seneste udviklinger på arbejdslivsområdet i landene og i EU, temadrøftelser samt allokering af projektmidler til udvalgte projekter.

Informationsprogrammet konsoliderede og videreudviklede sine hjemmesider og de elektroniske nyhedsbreve Arbeidsliv i Norden og Nordic Labour Journal og nåede sine kontraktmål.

Nordjobb opfyldte sine mål for antal komplette ansøgninger, nordjobbere og arbejdspladser. Ikke mindst Nord- 
jobbs nye satsning 'Jobbresan' bidrog hertil.

NIVA nåede sine kontraktmål for året. Årets resultat viste et pænt overskud og egenkapitalen lå ved regnskabsafslutningen på et normalt niveau.

\begin{tabular}{llrrrr} 
& & Budget & Budget & \multicolumn{2}{c}{ Difference } \\
& & $\mathbf{2 0 1 4}$ & $\mathbf{2 0 1 3}$ & \multicolumn{1}{c}{+ - } & \% \\
\hline MR-A (TDKK) & $\mathbf{1 3 . 6 9 8}$ & $\mathbf{1 3 . 9 9 2}$ & $\mathbf{- 2 9 4}$ & $\mathbf{- 2 , 1 \%}$ \\
& Projektmedel & 10.384 & 10.710 & -326 & $-3,0 \%$ \\
\hline $2-4110-1$ & Projektmidler i øvrigt - Arbejdsliv & 694 & 683 & 11 & $1,6 \%$ \\
$2-4111-2$ & Arbejdsliv faste udvalg & 4.989 & 5.400 & -411 & $-7,6 \%$ \\
$2-4120-2$ & Nordjobb & 3.113 & 3.064 & 49 & $1,6 \%$ \\
$2-4130-1$ & Kommunikation om arbejdsliv & 1.588 & 1.563 & 25 & $1,6 \%$ \\
& Institutioner & 3.314 & 3.282 & 32 & $1,0 \%$ \\
\hline $2-4180-3$ & Institut för vidareutb.inom arbetsmiljö & 3.314 & 3.282 & 32 & $1,0 \%$ \\
& (NIVA) & & & &
\end{tabular}

\begin{tabular}{crrrr}
\hline Opdelt på kategorier & $\mathbf{1 3 . 6 9 8}$ & $\mathbf{1 3 . 9 9 2}$ & $\mathbf{1 0 0 \%}$ & $\mathbf{1 0 0 \%}$ \\
\hline Projektmidler & 2.282 & 2.246 & $16,7 \%$ & $16,1 \%$ \\
Programlignende aktiviteter & 8.102 & 8.464 & $59,1 \%$ & $60,5 \%$ \\
Institutioner & 3.314 & 3.282 & $24,2 \%$ & $23,5 \%$
\end{tabular}

2-4110-1 Projektmedel i övrigt - Arbetsliv

\begin{tabular}{|l|c|c|c|c|c|} 
Valuta & Budget 14 & Budget 13 & Budget 12 & Disp./bud. 12 & Bud.disp. af \\
\hline DKK & 694.000 & 683.000 & 611.000 & $96 \%$ & EK-A
\end{tabular}

Formål

'Projektmidler - i øvrigt' anvendes bl.a. til finansiering af MR-As formandskabspulje, den nordisk-baltisk-polske EU-informationsgruppe og EK-As driftsmidler.

Prioriteringer i Budgetposten skal bidrage til gennemførelsen det island2014 ske formandskab og driften af det nordiske samarbejde på arbejdslivsområdet.

- MR-As formandskabspulje skal give mulighed for at yde økonomisk støtte til gennemførelsen af formandskabets konferencer og seminarer på arbejdslivsområdet. 
- Bevillingen til EU-informationsgruppen dækker udgifterne til gruppens eksterne sekretærfunktion, som er nødvendig for gennemførelsen af gruppens møder.

- EK-As driftsmidler skal sikre en smidig drift af Ministerrådet for arbejdsliv.

Ledelse og Planlagte udgifter 2014: 60.000 DKK

adm.

Faktiske udgifter 2012: 90.000 DKK

Sekretariats- $\quad$ NMRS står for sekretariatsfunktionen idet dog sekretarifunktion atsfunktion for EU-informationsgruppen varetages af det polske arbejds- og socialministerium.

\section{2-4111-2 Arbejdsliv faste udvalg}

\begin{tabular}{|l|c|c|c|c|c|} 
Valuta & Budget 14 & Budget 13 & Budget 12 & Disp./bud. 12 & Bud.disp. af \\
\hline DKK & 4.989 .000 & 5.400 .000 & 5.305 .000 & $83 \%$ & EK-A
\end{tabular}

Formål

EK-A uddelegerer årligt ansvaret for fordelingen og anvendelsen af sektorens projektstøttemidler til Arbejdsmarkedsudvalget, Arbejdsmiljøudvalget og Arbejdsretsudvalget. Udvalgene annoncerer hvert år et antal temaer inden for rammerne af MR-As samarbejdsprogram og formandskabsprogrammet, som man ønsker at fokusere projektstøttemidler på. Udvalgene behandler de indkomne ansøgninger og bevilger projektstøtten til de projekter, som bedst muligt kan bidrage til at belyse de valgte temaer. Projektstøtten anvendes også til finansiering af de eksterne sekretærer for de tre udvalg.

Gennem støtten til de konkrete projekter frembringer udvalgene især viden om aktuelle arbejdslivspolitiske emner, som kan bruges i de enkelte landes arbejdslivspolitikker og til at fremme nordiske synspunkter internationalt.

Prioriteringer i Udvalgene skal på deres halvårlige møder fokusere på 2014 implementering af målene i MR-As samarbejdsprogram 2013-2016 og det islandske formandskabs sektorprogram. 
Disse programmer skal dels styre udvalgenes arbejde generelt og dels deres annonceringer efter projektansøgninger. Udvalgene vil overordnet set fokusere på kortlægninger og analyser, som bidrager til at skabe ny viden om, hvordan Norden bedst kan udnytte de muligheder og imødegå de udfordringer, der udspringer af globaliseringen og den demografiske udvikling.

- Bidrage med erfaringsudveksling og øget kundskab om hvordan man kan reducere ungdomsledigheden og langtidsledigheden og indtænke behovet for at sikre en tilstrækkelig arbejdsstyrke med de rette kvalifikationer i Norden på længere sigt.

- Bidrage med erfaringsudveksling og øget kundskab om hvordan man kan styrke sundhed og velfærd for nordiske arbejdstagere yderligere gennem udvikling af kvaliteten i arbejdslivet.

- Bidrage med erfaringsudveksling og øget kundskab om hvordan man kan styrke balancen mellem lønmodtagerbeskyttelse og fleksibilitet på de nordiske arbejdsmarkeder samt fremme ligestilling og ligebehandling $\mathrm{i}$ arbejdslivet.

- Bidrage med erfaringsudveksling og øget kundskab om hvordan man kan gøre det nordiske arbejdsmarked endnu mere attraktivt med henblik på at tiltrække arbejdskraft og investeringer.

- Bidrage med erfaringsudveksling og øget kundskab om hvordan man kan styrke det nordiske samarbejde i forhold til international regulering.

Ledelse og Planlagte udgifter 2014: 400.000 DKK

adm.

Faktiske udgifter 2012: 400.000 DKK

Sekretariats- Der er tre eksterne sekretærer ansat på deltid i landene til funktion at varetage sekretærfunktionen i de tre udvalg. 
2-4120-2 Nordjobb

\begin{tabular}{|l|c|c|c|c|c|} 
Valuta & Budget 14 & Budget 13 & Budget 12 & Disp./bud. 12 & Bud.disp. af \\
\hline DKK & 3.113 .000 & 3.064 .000 & 2.810 .000 & $97 \%$ & FNF
\end{tabular}

Formål

Formålet med Nordjobb-projektet er at anvende det fælles nordiske arbejdsmarked til at tilbyde unge (18-28 år) et sommerjob, en bolig og et fritidsprogram i et andet nordisk land. Samtidig skal projektet give nordiske arbejdsgivere mulighed for at trække på arbejdskraft fra andre nordiske lande i sommerperioden.

Prioriteringer i Nordjobb skal opnå en række konkrete mål for antal 2014 komplette ansøgninger, arbejdspladser, deltagere og fritidsledere.

$\begin{array}{ll}\text { - } & 4700 \text { komplette ansøgninger } \\ \text { - } & 760 \text { arbejdspladser } \\ & 760 \text { deltagere }\end{array}$

Ved forhandlingerne mellem Nordisk Ministerråd og Nordisk Råd om budgettet for 2014 er der opnået enighed om:

-at det innenfor budsjettrammen for Nordjobb avsettes midler for å markedsføre «Jobbresan» til kommuner i Norden.

Ledelse og Planlagte udgifter 2014: 900.000 DKK

adm.

Faktiske udgifter 2012: 900.000 DKK

Sekretariats- Foreningerne Nordens Forbund

funktion

2-4130-1 Kommunikation om arbetsliv

\begin{tabular}{|l|c|c|c|c|c|} 
Valuta & Budget 14 & Budget 13 & Budget 12 & Disp./bud. 12 & Bud.disp. af \\
\hline DKK & 1.588 .000 & 1.563 .000 & 1.595 .000 & $100 \%$ & EK-A
\end{tabular}

Formål Formålet med Kommunikation om arbejdsliv er at udbrede kendskabet i og uden for Norden til arbejdslivsområdet 


\section{i Norden.}

Budgetposten dækker følgende opgaver og udgifter (2013-priser):

1. Informationsprogrammet varetager opgaven som ekstern redaktør for webmagasinet (www.arbeidslivinorden.org) og de elektroniske nyhedsbreve på skandinavisk og engelsk: 1.170 .000 DKK

2. Oversættelser til engelsk: $85.000 \mathrm{DKK}$

3. Støtte til nyhedsbrevet 'EU \& arbetsrätt' og dets webportal(www.arbetsratt.juridicum.su.se): 308.000 DKK.

Prioriteringer i Kommunikationen om arbejdsliv sker i henhold til MR2014 As informations- og kommunikationsstrategi 2013-2016. Som en del heraf vil den ekterne ansvarlige redaktør sikre vedligeholdelse af webmagasinet og udsendelse af de elektroniske nyhedsbreve Arbeidsliv i Norden og Nordic Labour Journal til brede målgrupper.

- Antallet af abonnenter skal forøges i forhold til 2013.

- Informationsprogrammet skal udgive 9 nyhedsbreve årligt på både skandinavisk og engelsk.

- Samarbejdet mellem Informationsprogrammet og andre relevante webportaler skal udvikles til gensidig nytte.

Ledelse og Planlagte udgifter 2014: 800.000 DKK adm. Faktiske udgifter 2012: 846.000 DKK

Sekretariats- Webmagasin og elektroniske nyhedsbreve udgives af funktion Arbeidsforskningsintituttet i Norge efter aftale med EK-A

2-4180-3 Institut for videreuddannelse inden for arbejdsmiljø (NIVA)

\begin{tabular}{|l|c|c|c|c|c|} 
Valuta & Budget 14 & Budget 13 & Budget 12 & NMR fin. 12 & Bud.disp. af \\
\hline EUR & 444.200 & 441.100 & 430.300 & $75 \%$ & Institutionen \\
\hline $\begin{array}{l}\text { Modsv. } \\
\text { DKK }\end{array}$ & 3.314 .000 & 3.282 .000 & 3.206 .000 & &
\end{tabular}


og arbejdssundhed gennem tilbud om videreuddannelse på højt nordisk og internationalt niveau af forskere, praktikere i myndigheder og virksomheder samt øvrige aktører. Videreuddannelsen foregår på engelsk via kurser, seminarer og symposier, der er baseret på nordisk og international forskning og politik på arbejdsmiljø- og arbejdslivsområdet.

Prioriteringer i NIVA skal fungere som et forum for udvikling af nye 2014 ideer og tilpasninger af afprøvede løsninger. Et vigtigt mål er at opbygge et specialistnetværk. Samarbejdet er specielt vigtigt på områder, hvor de enkelte lande har relativt få egne eksperter. På disse områder er det særligt vigtigt, at specialister fra de forskellige lande har mulighed for regelmæssigt at udveksle erfaringer og opdatere sine kundskaber.

- Flere af kurserne bør fokusere på psykosociale spørgsmål inden for arbejdsorganisationen, f.eks. vedrørende aldring, mobning og vold.

- Der bør også planlægges kurser om metodologiske og epidemiologiske spørgsmål, forebyggelse, tilbagegang til arbejdet, holdbar udvikling $i$ arbejdslivet, fremme af arbejdsevnen, ergonomi, toxikologi, arbejdshygiejne, astma, allergi og dermatologi.

- NIVA skal gennemføre 8-15 kurser/seminarer /symposier pr. år.

- Målet for antal deltagere pr. år er 300. Derudover er det en prioritering, at bevilge op til ti stipendier årligt til deltagere fra Rusland.

- Fremme viden og bygge netværk internationalt om nordisk arbejdsmiljøviden og -forskning

- Effektivisering af markedsføringen af NIVAs kursustilbud bl.a. gennem øget anvendelse af elektronisk kommunikation, herunder publicere et elektronisk nyhedsbrev tre gange årligt.

- Der skal forberedes en ny kontrakt for NIVA 2015-17 på grundlag af den eksterne evaluering af NIVA fra 2013.

Kontrakt- $\quad$ 2012-2014 periode 
Arbejdslivspolitik

Kontrakt- Kontraktmålene for 2012 blev nået.

status

Økonomi NIVAs aktiviteter i 2012 gav et pænt overskud og egenkapitalen ligger på et normalt niveau.

Ledelse og Planlagte udgifter 2014: 750.000 DKK adm.

Faktiske udgifter 2012: 738.000 DKK 


\section{Ekonomi- og Finanspolitik}

\section{Generel indledning}

Generelt

Ministerrådets styringsdokumenter
Nordiska ministerrådets samarbete på det ekonomiska och finansiella området skall bidra till att skapa förutsättningar för att de grundläggande ekonomisk-politiska målen om en stabil och sund ekonomisk utveckling med hög sysselsättning och god och uthållig tillväxt skall kunna uppnås.

EU-frågor är av fortsatt hög prioritet inom det nordiska ekonomiska och finansiella samarbetet. Sektorn har en ordning för systematiskt samråd och samarbete om EUfrågor på det ekonomiska och finansiella området. Flera EU-relaterade frågor som kommer att behandlas inom ramen för Ekofin-rådets verksamhet kan förutses att bli aktuella. Andra områden som väntas utgöra viktiga delar av arbetet inom sektorn under 2014 är uppföljningen av arbetet med att avlägsna gränshinder mellan de nordiska länderna, systematiskt samråd och samarbete om skattefrågor, samråd och samarbete om stabilitet på finansmarknaden, samt samarbete för att verka för att den ekonomiska dimensionen inkorporeras på ett tydligare sätt $\mathrm{i}$ den nordiska strategin om hållbar utveckling.

Sektorns arbete understöds av en rad arbetsgrupper som t.ex. nordiska miljö- och ekonomigruppen, nordiska konjunkturgruppen och den nordiska skattegruppen. Dessa grupper väntas komma med centrala inspel till ämbetsmannakommittén och de nordiska finansministrarna.

Sektorns styr av de överordnade prioriteringar de nordiska finansministrarna beslutade om under 2007, i dokument om kärnuppgifter för MR-Finans. De övergripande målsättningarna är bl.a. att verka för en stabil och hållbar ekonomisk tillväxt, att verka för utvecklingen av den nordiska välfärdsmodellen, att främja den ekonomiska integrationen inom Norden och med Östersjöregionen och Europa samt att främja gemensamma nordiska intressen 
internationellt.

Resumé af

Minister-

rådets resultater

i 2012
Nordiskt samarbete kring informationsutbyte på skatteområdet

I syfte att följa upp OECD:s arbete mot internationell skatteflykt beslutade de nordiska länderna i juni 2006 att inleda gemensamma förhandlingar med finansiella offshorecentra (sk. skatteparadis). Fram till den mars 2013 har de nordiska länderna ingått informationsutbytesavtal med 41 stater och fler avtal förväntas ingås under 2013. ÄK-Finans beslutade under 2012 att även stödja de nordiska skattemyndigheterna samarbete om uppföljning av informationsutbytesavtalen, genom arbetet med en informationsportal för de nordiska skatterevisorerna.

Utgivningen av en Nordisk ekonomisk-politisk forskningstidsskrift

Med målsättningen att göra aktuell ekonomisk-politisk forskning mer användbar för beslutsfattare samt att främja en bredare diskussion av ekonomisk-politiska frågor i de nordiska länderna etablerades 2009 en Nordisk forskningstidskrift med namnet Nordic Economic Policy Review. Total sju nummer planeras utges under perioden och som avslutas 2013. Tidskriftens artiklar diskuterades även på de nordiska finansministrarnas möte under 2010, 2011 och 2012.

\section{Ekonomiska instrument i miljöpolitiken}

Arbetet i Miljö-ekonomigruppen, som är en gemensam grupp mellan MR-Finans och MR-Miljö, har resulterat i ett antal studier och rapporter. Under 2012 har man genomfört analyser som berör områdena "Miljöeffektiv teknologi", "Gröna jobb", "Mål och räkenskap för hållbar miljö", "Grön budget", "Effektiva styrmedel för förnybar energi", "Ekonomiska styrmedel för fartygstrafik", samt "Naturkapital". Arbetet i gruppen har inneburit ett värdefullt tillskott inför beslut i de nordiska länderna omkring olika ekonomiska faktorers och styrmedels betydelse för miljön. 
Samarbete för implementeringen av EU regler om kapital- och likviditetskrav i bankerna.

Vid MR-Finans möte den 1 november 2011 beslutade ministrarna att nedsätta en Nordisk arbetsgrupp med uppgift att utarbeta ett internt dokument som värderar de utmaningar de nordiska länderna var för sig står inför med avseende på CDR IV (Basel III). Vid MRFinans i juli 2012 presenterades gruppens arbete som gav ett antal rekommendationer på områden där man senare inviterade de nationella Finanstillsynerna att se vidare på ett samarbete. De nordiska länderna är starkt engagerade $i$ arbetet med att stabilisera finansmarknaden och ska fortsätta sitt samarbete om reglering av finansmarknaden.

\section{Arbetet med att undanröja gränshinder}

Gränshindersfrågor är ett prioriterat område för samarbetet. Såväl MR-Finans som ÄK-Finans har under 2012 behandlat gränshindersfrågor på samtliga möten. Vid MR-Finans i juli 2012 deltog representant från Gränshindersforum och framförde synpunkter angående bland annat beskattning av pensioner. Till det efterföljande MR-Finans möte i oktober 2012 utarbetades en analys av för och nackdelar med olika beskattningsmetoder i internationella dubbelbeskattningsavtal.

Finansiering av gröna företag och investeringar, uppföljning av statsministrarnas uppdrag om grön tillväxt. Finansministrarnas har fått i uppdrag av statsministrarna att ge förslag till hur de kan samordna och förstärka sina insatser i finansiella institutioner där de nordiska länderna är centrala aktörer för att stödja finansieringen av växande gröna företag och investeringar. Under 2012 har ÄK-Finans låtit utarbeta en bakgrundsanalys som belyser arbetet med investeringar som kan främja en grön utveckling inom ramen för internationella finansiella institutioner $\mathrm{i}$ vårt närområde. 


\begin{tabular}{|c|c|c|c|c|}
\hline & \multirow{2}{*}{$\begin{array}{c}\text { Budget } \\
2014\end{array}$} & \multirow{2}{*}{$\begin{array}{c}\text { Budget } \\
2013\end{array}$} & \multicolumn{2}{|c|}{ Difference } \\
\hline & & & $+/-$ & $\%$ \\
\hline MR-Finans (TDKK) & 1.819 & 1.855 & -36 & $-1,9 \%$ \\
\hline Projektmedel- Ekonomi och finanspolitik & 1.819 & 1.855 & -36 & $-1,9 \%$ \\
\hline Opdelt på kategorier & 1.819 & 1.855 & $100 \%$ & $100 \%$ \\
\hline Projektmidler & 1.819 & 1.855 & $100 \%$ & $100 \%$ \\
\hline
\end{tabular}

4-5210-1 Projektmedel - Ekonomi- och Finanspolitik

\begin{tabular}{|l|c|c|c|c|c|} 
Valuta & Budget 14 & Budget 13 & Budget 12 & Disp./bud. 12 & Bud.disp. af \\
\hline DKK & 1.819 .000 & 1.855 .000 & 1.822 .000 & $91 \%$ & $\begin{array}{c}\text { EK-MR- } \\
\text { Finans }\end{array}$
\end{tabular}

Formål

Nordiska Ministerrådets ekonomi- och finanssektor har som målsättning att främja det nordiska samarbetet vad gäller ekonomiska och finanspolitiska frågor. Med utgångspunkt i ministerrådets kärnuppgifter och ordförandeskapsprogrammet, skall genomförandet av de prioriteringar som finansministrarna har beslutat säkras. Utifrån särskilda riktlinjer ges ekonomiskt stöd till olika instrument som används till att uppnå dessa mål, bl.a. genom seminarier, konferenser och olika utredningar m.m.

Prioriteringer i Island innehar ordförandeskapsposten under 2014. Me2014 ningen är att utvecklingen av nyttiga projekt fortsätter och diskuteras innanför det nordiska området. Vikten läggs på generella politiska överenskommelser och utväxling av information med hänseende att skapa solidaritet bland de nordiska nationerna omkring stora frågor, som inte minst är viktiga i dessa tider som karaktäriseras av ekonomisk instabilitet. Island arbetar för att fortsätta det projektinriktade samarbetet. Samarbetet mellan de nordiska länderna inom informationsavtal med finansiella off-shorecentran (sk. skatteparadis) är ett gott exempel på detta - och det samma vill gälla för det ytterligare arbete som är igång för att undanröja gränshinder. På dagordningen önskas det vidare en diskussion om den ekonomiska och statsfi- 
nansiella utvecklingen samt att det förbereds en diskussion om enskilda projekt som kräver ministrarnas uppmärksamhet. Island ser gärna större deltagande från de självstyrande områdena på det finansiella och ekonomiska planet i framtiden.

Prioriteringarna förutsätter en fortsatt aktiv nordisk dialog om bland annat ekonomisk politik, konjunkturbevakning, budgetfrågor, strukturfrågor, skatter och avgifter, samt regelverket för finansiell sektor. Informationsutväxling och diskussion av EU-frågor på det ekonomiska och finansiella området vill fortsatt vara ett viktigt tema under de nordiska finansministermötena. Samarbetet skall också bidra till att införandet av direktiv och andra EU/EESrättsakter blir så likartat som möjligt.

Prioriteringar inkluderar en rad samarbeten som etablerats sedan tidigare:

\section{Samarbete mot skatteflykt}

De gemensamma nordiska förhandlingarna om informationsutbytesavtal på skatteområdet fortsätter under 2013. MR-Finans kommer under 2013 och 2014 följa arbetet i länderna av de informationsutbytesavtal som ingåtts genom det nordiska förhandlingssamarbetet, och därunder arbetet med skattemyndigheternas informationsportal.

\section{Gränshindersarbetet}

Arbetet med att undanröja gränshinder i Norden är fortsatt ett av ekonomi- och finanssektorns prioriterade områden. På området sker kontinuerligt ett nordiskt samarbete, dels genom den nordiska skatteportalen och dels genom bilateralt samarbete i Norden. De senaste åren har arbetet med att lösa gränshindersfrågor intensifierats.

\section{Nordic Economic Policy Review}

Ministerrådet beslutade att en utgåva av den ekonomiskpolitiska tidskriften Nordic Economic Policy Review (NEPR) med temat "Fler unga i arbete i Norden" kommer ges ut våren 2013, kopplat till det svenska ordförande- 
skapet i Nordiska Ministerrådet.

Beslut om en eventuell vidareföring av tidsskriften 2014

förväntas beslutas under första delen av 2013.

Finansiering av gröna företag och investeringar, uppföljning av statsministrarnas uppdrag om grön tillväxt.

På det nordiska statsministermötet den 1 november 2011 gavs i uppdrag att vidareutveckla åtta konkreta förslagen som presenterades i rapporten "Norden-ledande i grön tillväxt" från arbetsgruppen för grön tillväxt. Finansministrarnas fick i uppdrag att ge förslag till hur de kan samordna och förstärka sina insatser i finansiella institutioner där de nordiska länderna är centrala aktörer för att stödja finansieringen av växande gröna företag och investeringar. Arbetet med uppdraget kommer följas upp under 2013 och 2014. Miljö-ekonomigruppen är involverade i detta arbete.

Uppföljning av arbetsmarknadstoppmöte med fokus på ungdomsarbetslöshet

I samband med MR-Finans möte under hösten 2013 så kan det vara aktuellt att följa upp eventuella nya initiativ och frågeställningar som uppkommit vid statsministrarnas arbetsmarknadstoppmöte i maj. 


\section{Lagstiftning}

\section{Generel indledning}

Generelt

Samarbejdet indenfor justitssektoren angår bl.a. forberedende lovgivningsarbejde, initiativer til forebyggelse og bekæmpelse af kriminalitet, samarbejde med hensyn til EU/EØS-ret, behandling af projektansøgninger samt samarbejde med de retshåndhævende myndigheder i de baltiske stater.

Med henblik på fortsat at arbejde mod en ensartet retlig udvikling i overensstemmelse med Helsingforsaftalens målsætninger og opfyldelse af justitssektorens samarbejdsprogram, gennemgås og drøftes aktuelle nordiske lovgivningsinitiativer, og ved behov gennemføres endvidere konkrete lovgivningsprojekter.

Under Ministerrådet er etableret Nordisk Baltisk Kontaktgruppe (NBCG). NBCG har som overordnet formål at fremme og styrke det retlige samarbejde mellem de nordiske og de baltiske lande. NBCG har som hovedopgaver, at pege på fælles prioriteringer for samarbejdet, at identificere konkrete projekter og aktiviteter, at arrangere seminarer m.v., at erfaringsudveksle og at forberede de ministermøder, som finder sted hvert andet år.

Udover det formaliserede nordiske samarbejde indenfor Justitssektoren findes et løbende praktisk samarbejde. På embedsmandsniveau afholdes kontaktmøder, seminarer m.v. mellem fx landenes Domstolsadministrationer, Rigsanklagere, Rigspolitichefer og Kriminalforsorgen.

Ministerrådets styringsdokumenter
Justitssektorens overordnede samarbejdsprogram blev senest revideret i 2011 og gælder indtil udgangen af 2014.

Samarbejdsprogrammet indeholder principperne for det nordiske lovgivningssamarbejde. Det er en grundlæggen- 
Resumé af

Ministerrådets resultater $\mathrm{i}$ 2012 de værdi for det retlige samarbejde, at det skal styrke demokratiske beslutningsprocesser og fremme individets retssikkerhed. Som et grundlæggende princip er videre anført, at det er en målsætning for den nordiske lovgivning, at borgere og virksomheders frie bevægelighed i Norden ikke skal hæmmes af unødvendige grænsehindringer.

De årlige formandsskabsprogrammer for Justitssektoren supplerer det overordnede samarbejdsprogram og tilsammen danner disse grundlaget for Ministerrådets virke.

Ministerrådet har ydet økonomisk støtte til forskellige juridiske projekter, herunder

- Forskningsprojekt om administrative sanktioner/bøder forankret på Helsingfors Universitet. Forskningsprojektet videreførtes i 2013.

- Støtte til Retspolitisk Forskningsinstitut, Helsingfors til gennemførelse af et møde i regi af European Homicide Monitor Project

- Støtte til projekt om evaluering af exit-indsatser for rocker/bandemedlemmer, Forskningskontoret, Justitsministeriet, DK

Ministerrådet har endvidere modtaget og drøftet en redegørelse om det nordiske politisamarbejde og en redegørelse om det nordiske arbejde med efterforskning m.v. af krigsforbrydelser.

Ministerrådet har videre indledt en drøftelse af de generelle principper for ministerrådets arbejde og prioriteringer med henblik på at øge effektiviteten og resultaterne af samarbejdet. Drøftelserne videreførtes i 2013.

Ministerrådet har taget initiativ til etablering af en nordisk følgegruppe, som har til formål at søge at finde fælles nordiske synspunkter m.v. med hensyn til de forslag til (nye) databeskyttelsesregler der er fremsat af EUKommissionen i 2012. 
Blandt Ministerrådets aktiviteter var også drøftelser med landenes Rigsadvokater om aktuelle kriminalretslige og kriminalpolitiske problemstillinger.

Endelig bemærkes, at de nordiske og de baltiske ministre på et møde i Riga i Letland fornyede mandatet til NBCG og samtidig vedtog konklusioner, som i den kommende tid er retningsgivende for gruppens arbejde og gennemførelse af juridiske seminarer m.v.

\begin{tabular}{|c|c|c|c|c|c|}
\hline & \multirow{2}{*}{$\begin{array}{c}\text { Budget } \\
2014\end{array}$} & \multirow{2}{*}{$\begin{array}{c}\text { Budget } \\
2013\end{array}$} & \multicolumn{2}{|c|}{ Difference } \\
\hline & & & & $+/-$ & $\%$ \\
\hline Sum MR & Lag (TDKK) & 1.390 & 1.418 & -28 & $-2,0 \%$ \\
\hline $1-7110-1$ & Projektmedel - Lagstiftning & 1.390 & 1.418 & -28 & $-2,0 \%$ \\
\hline & Opdelt på kategorier & 1.390 & 1.418 & $100 \%$ & $100 \%$ \\
\hline & Projektmidler & 1.390 & 1.418 & $100 \%$ & $100 \%$ \\
\hline
\end{tabular}

1-7110-1 Projektmedel - Lagstiftning

\begin{tabular}{|l|c|c|c|c|c|} 
Valuta & Budget 14 & Budget 13 & Budget 12 & Disp./bud. 12 & Bud.disp. af \\
\hline DKK & 1.390 .000 & 1.418 .000 & 1.393 .000 & $84 \%$ & $\begin{array}{c}\text { MR- } \\
\text { LAG/NÄL }\end{array}$
\end{tabular}

Formål

Med udgangspunkt i Ministerrådets samarbejdsprogram og i formandsskabs-programmet gennemføres de prioriteringer, som er besluttet og som fremgår nedenfor. De priorieterede temaer kan fx søges opfyldt i form af økonomisk støtte til seminarer, udredninger, projekter og lignende.

Prioriteringer i Ministerrådet vil følge op på projekter og udredninger 2014 m.v. som er igangsat i tidligere år og sikre, at der foretages den fornødne retlige og administrative evaluering heraf.

Ministerrådet vil i forlængelse af en drøftelse af Minister- 
rådets arbejdsform og hvilken effekt dets aktiviteter har, iværksætte de eventuelt fornødne initiativer.

Ministerrådet vil endvidere gennemføre drøftelser med henblik på stillingtagen til eventuelle justeringer i justitssektorens samarbejdsprogram.

Herudover prioriteres særligt formandsskabets program, sikring og bevaring af åbne, demokratiske nordiske samfund samt arbejdet i den nedsatte nordiske følgegruppe om udkast til nye EU-regler om databeskyttelse.

Prioriteringer i 2014 vedr. projektmidler:

- Formandskabets program og prioriteringer

- Sikring og bevaring af åbne, demokratiske nordiske samfund

- Sikring og udvikling af den nordiske velfærdsmodel i et retligt perspektiv 


\section{Internationalt samarbejde}

\section{Generel indledning}

Generelt Ministerrådets internationale budget omfatter samarbejdet med Nordens nabolande med hovedfokus på landene rundt om Østersøen især Estland, Letland og Litauen og Nordvestrusland, det arktiske samarbejde, samt naboerne i Vest. Samarbejde med andre regionale organisationer, Arktisk Råd, Barentsrådet, Østersørådet, EU hører også under dette politikområde. Samarbejdet med Arktisk Råd hvor Ministerrådet er permanent observatør, har en selvstændig status indenfor NMRs Arktiske Samarbejdsprogram. Endvidere er støtte til demokratiudvikling i Hviderusland samt støtte til NGO-samarbejde i Østersøregionen omfattet. Dertil kommer, at en del af fagministerrådenes internationale samarbejde finansieres fra fagministerrådenes budgetter.

Ministerrådet ønsker at fokusere mere på nordisk samarbejde globalt og har derfor oprettet en ny budgetpost Internationalt samarbejde og benævner nu Nabosamarbejdet for Internationalt samarbejde.

Udmøntning af Den samlede besparelse på NMRs internationale budget besparelse $\mathrm{i}$ udgør i 2014 7,98 millioner DKK, svarende til 8.3\% (i budget 2014 2013 priser). Blandt andet beskæres budgetpost 6-0980-1 Partnerskab og grænseregionalt samarbejde med 3.850.000 DKK og budgetpost 6-0970-3 Ministerrådets kontor i Nordvestrusland med 1 million DKK, idet Kaliningrad-kontoret administrativt lægges under Skt. Petersborg-kontoret. Budgetpost 6-5280-3 Nopef beskæres med $8,3 \%$, svarende til 1.330.000 DKK. Den resterende del af besparelsen fordeles på budgetpost 6-870-1 Arktisk Samarbejdsprogram med 0,5 millioner DKK, budgetpost 60990-1 Samarbejde med Nordens naboer i Vest med 1,0 millioner DKK og EHU/Hviderusland med 300.000 DKK

Ministerrådets Det internationale samarbejde har flere styringsdokumenstyringster. Nye retningslinjer for samarbejdet med Estland, Letland og Litauen gældende fra 2014 er blevet udarbejdet i 
dokumenter løbet af 2012-2013 og blev godkendt af Nordisk Råds session i 2013. Tilsvarende nye retningslinjer forventes godkendt for samarbejdet med Nordvestrusland. Retningslinjerne understreger, at samarbejdet skal have udgangspunkt i det nordiske samarbejde og være til nordisk nytte. Særligt prioriterede er samarbejdsområder, hvor en positiv udvikling er i de nordiske landes interesse. Dette omfatter dels problemstillinger af grænseoverskridende karakter såsom organiseret kriminalitet, menneskehandel, smitsomme sygdomme og miljøspørgsmål, dels styrkelse af den økonomiske og sociale udvikling, demokratiudvikling, menneskerettigheder og god forvaltningsskik. Samarbejdet skal også understøtte gennemførelsen af den Nordlige Dimension og EU's Østersøstrategi samt andre overordnede politiske rammeværk, hvori de nordiske lande deltager. For det arktiske samarbejde er der i 2011 vedtaget et samarbejdsprogram for 2012-2014 "Bæredygtig udvikling i Arktis". Samarbejdet med Nordens naboer i Vest foregår indenfor rammerne af retningslinjer for perioden 2012-2016, mens opdaterede retningslinjer for Hvideruslandsaktiviteter blev godkendt af Nordisk Råds session i 2013. Generelle retningslinjer for NMRs samarbejde med Barentsrådet, Østersørådet og Arktisk Råd blev besluttet af MR-SAM i september 2005. Andre styringsdokumenter er Den Nordlige Dimensions Policy Framework Document og EU's Østersøstrategi. I tillæg til disse styringsdokumenter kommer formandskabsprogrammer samt de enkelte fagministerråds handlingsplaner og programmer og initiativer, som koordineres med indsatser under det internationale samarbejde.

Resumé af Arbejdet om udvikling af nye retningslinjer for samarbejMinisterdet med Estland, Letland og Litauen er blevet igangsat. rådets resulta- De fælles nordisk-baltiske mobilitetsprogrammer på omter i 2012 råderne tjenestemandsudveksling, næringsliv og kultur er blevet videreført. Arbejdet med programmet for kundskabsopbygning og netværk for Nordvestrusland er blevet intensiveret og nye projekter lanceret på en lang række områder, herunder CSR, arbejdsmarked, kommunesamarbejde, bekæmpelse af menneskehandel, kreative industri- 
er. På basis af det i 2011 underskrevne Memorandum of Understanding mellem Nordisk Ministerråd og det russiske føderale Undervisnings- og forskningsministerium er det nye fælles nordisk-russiske samarbejdsprogram for uddannelse og forskning blevet lanceret. Ministerrådet har i 2012 bidraget til handlingsplanen for EU's Østersøstrategi med en række konkrete projekter og har fået en mere aktiv rolle i gennemførelse af handlingsplanens prioritetsområder. Ministerrådet har endvidere støttet udviklingen af Partnerskabet for Kultur under den Nordlige Dimension ved at være vært for Partnerskabets sekretariat i 2011 2013. Ministerrådet har i 2012 fortsat støttet det hviderussiske eksiluniversitet European Humanities University i Vilnius samtidig med at ministerrådet har administreret to EU-finansierede programmer til støtte for civilsamfundet og hviderussiske studerende. Det arktiske samarbejde er blevet udviklet med udgangspunkt i det nye Arktiske Samarbejdsprogram for 2012-2014, som giver mulighed for mere prioriterede og fokuserede indsatser. Samarbejdet med Nordens naboer i vest har især fokuseret på udvikling af samarbejdet med Canada.

\begin{tabular}{|c|c|c|c|c|c|}
\hline & \multirow{2}{*}{$\begin{array}{c}\text { Budget } \\
2014\end{array}$} & \multirow{2}{*}{$\begin{array}{l}\text { Budget } \\
2013\end{array}$} & \multicolumn{2}{|c|}{ Difference } \\
\hline & & & & $+/-$ & $\%$ \\
\hline \multicolumn{2}{|c|}{ Internationalt samarbejde (TDKK) } & 89.718 & 95.592 & -5.874 & $-6,1 \%$ \\
\hline $6-0820-2$ & Kunskapsuppbyggning och nätverk & 27.962 & 27.522 & 440 & $1,6 \%$ \\
\hline $6-0980-1$ & Partnerskab og grænseregionalt samarbejde & 2.438 & 6.230 & -3.792 & $-60,9 \%$ \\
\hline $6-0960-1$ & NGO-virksomhed i Østersøregionen & 6.231 & 6.133 & 98 & $1,6 \%$ \\
\hline $6-5280-2$ & Nopef & 14.938 & 16.053 & -1.115 & $-6,9 \%$ \\
\hline $6-0970-3$ & $\begin{array}{l}\text { Ministerrådets kontorer i Nord-vest Rus- } \\
\text { land }\end{array}$ & 9.383 & 10.244 & -861 & $-8,4 \%$ \\
\hline $6-0810-3$ & $\begin{array}{l}\text { Ministerrådets kontorer i Estland, Letland } \\
\text { og Litauen }\end{array}$ & 11.694 & 11.521 & 173 & $1,5 \%$ \\
\hline 6-0910-1 & Politiske initiativer & 0 & 986 & -986 & - \\
\hline $6-0850-1$ & Internationellt samarbete & 1.727 & 0 & 1.727 & - \\
\hline $6-0870-1$ & Arktisk samarbeidsprogram & 9.335 & 9.688 & -353 & $-3,6 \%$ \\
\hline $6-0950-2$ & EHU/Hviderusland & 4.432 & 4.662 & -230 & $-4,9 \%$ \\
\hline 6-0990-1 & Samarbejde med Nordens naboer i Vest & 1.578 & 2.553 & -975 & $-38,2 \%$ \\
\hline
\end{tabular}

\begin{tabular}{ccccc}
\hline Opdelt på kategorier & $\mathbf{8 9 . 7 1 8}$ & $\mathbf{9 5 . 5 9 2}$ & $\mathbf{1 0 0 \%}$ & $\mathbf{1 0 0} \%$ \\
\hline Projektmidler & 21.309 & 25.590 & $23,8 \%$ & $26,8 \%$ \\
Programlignende aktiviteter & 47.332 & 32.184 & $52,8 \%$ & $33,7 \%$ \\
Institutioner & 21.077 & 37.818 & $23,5 \%$ & $39,6 \%$
\end{tabular}


6-0820-2 Kunskapsuppbyggning och nätverk

\begin{tabular}{|l|c|c|c|c|c|} 
Valuta & Budget 14 & Budget 13 & Budget 12 & Disp./bud. 12 & Bud.disp. af \\
\hline DKK & 27.962 .000 & 27.522 .000 & 27.235 .000 & $95 \%$ & $\begin{array}{c}\text { NSK/MR- } \\
\text { SAM }\end{array}$
\end{tabular}

Formål

Budgetpostens overordnede formål er at skabe netværk mellem de nordiske lande og Nordvestrusland henholdsvis de baltiske lande. Budgetposten finansierer dels de fælles nordisk-baltiske mobilitetsprogrammer, dels programmet for kundskabsopbygning og netværk, som er ministerrådets centrale instrument i samarbejdet med Nordvestrusland.

De fælles nordisk-baltiske mobilitetsprogrammer er det primære finansieringsinstrument til fremme af samarbejdet med Estland, Letland og Litauen. Ministerrådets samarbejde med de baltiske lande er først og fremmest et politisk samarbejde med udgangspunkt i fælles prioriteter og fælles nytte. Samarbejdet under-støttes af de fælles nordisk-baltiske mobilitetsprogrammer på områderne tjenestemandsudveksling, erhvervssamarbejde henholdsvis kultur, som blev lanceret i 2009. En videreførelse af programmerne for tjenestemænd og erhvervssamarbejde efter 2013 drøftes. Kulturprogrammet fortsætter til og med 2014. De fælles nordisk-baltiske mobilitetsprogrammer er finansieret ud fra landenes relative økonomiske størrelse målt ved bruttonationalindkomsten og er forankret i relevante fagministerråd. Der er krav om deltagerbetaling på minimum $30 \%$. Programmerne fremmer netværksopbygning mellem de nordiske og de baltiske lande og understøtter dermed det politiske samarbejde. Programmerne er åbne for deltagere fra de baltiske og de nordiske lande. Administrationen af programmerne varetages af Ministerrådets kontorer i Tallinn og Riga samt af Kultur Kontakt Nord. Bevillingen til en fortsættelse af de nordisk-baltiske mobilitetsprogrammer forudsættes fastholdt på minimum samme niveau som i 2013. 
Samarbejdet med Nordvestrusland fokuseres på områder, hvor der både er fælles nordisk nytte og hvor der kan opnås enighed med russiske partnere om vigtigheden af samarbejdet. Samarbejdet komplementerer de nordiske landes bilaterale samarbejde. Programmet for kundskabsopbygning og netværk for Nordvestrusland tager udgangspunkt i nordiske prioriteringer af samarbejdsområder med Nordvestrusland. Programmet har hidtil indeholdt fire hovedområder:

1. Offentlig forvaltning

2. Uddannelse og forskning

3. Forbedring af forudsætningerne for økonomisk samarbejde

4. Civilsamfund

Hovedområderne omfatter en række delprogrammer med fælles finansiering, hvor der fra og med 2014 skal tilstræbes en ligelig fordeling af finansieringen mellem nordiske og rusiske partnere (50-50), dog undtaget samarbejde om styrkelse af civilsamfundet. En top-down approach anvendes til identifikation af samarbejdspartnere for at sikre forankring i de politisk fastsatte prioriteter. Programmet er fleksibelt for udvikling af nye delprogrammer med nye aktører indenfor de fire hovedområder, samtidig med at det er fokuseret på klart identificerede områder, hvor der er ønske om samarbejde. Programmets administration varetages dels af Nordisk Ministerråds kontor i Nordvestrusland og relevante nordiske institutioner, dels af de medvirkende myndigheder, institutioner og organisationer. Ministerrådets kontor i Nordvestrusland medvirker derudover til at identificere relevante aktører for programmet.

Budgetposten indeholder derudover en pulje til at sikre synergi mellem det nordiske samarbejde med de baltiske lande og med Nordvestrusland på områder, hvor det synes hensigtsmæssigt med et bredere regionalt samarbejde. Puljen kan finansiere aktiviteter initieret af NMRS, fag- 
ministerråd eller NMRs kontorer og institutioner for at komplementere indsatser på prioriterede områder, hvor en russisk henholdsvis baltisk dimension er ønsket. Sådanne indsatser kan medvirke til implementering af den Nordlige Dimension og EU's Østersøstrategi.

Den årlige rapportering til MR-SAM indeholder en kvalitativ bedømmelse af samarbejdsinstrumenterne.

Prioriteringer i I 2014 vil der med udgangspunkt i nye retningslinjer ske 2014 en fortsat udvikling af samarbejdet mellem de nordiske lande og Nordvestrusland henholdsvis Estland, Letland og Litauen indenfor rammerne af kundskabs- og netværksprogrammet og de nordisk-baltiske mobilitetsprogrammer:

- Udvikling af samarbejde på de nye prioriteringsområder i Ministerrådets retningslinjer for samarbejde med Nordvestrusland.

- Udvikling af nye tiltag og initiativer forankret i fagministerrådene inden for programmet for kundskabsopbygning og netværk i Nordvestrusland.

- Udvikling af nordisk-baltisk-russisk samarbejde med henblik på at bidrage på områder af relevans for EU's Østersøstrategi og den Nordlige Dimension.

- Videreudvikling af de nordisk-baltiske mobilitesprogrammer.

\section{6-0980-1 Partnerskap och gränsregionalt samarbete}

\begin{tabular}{|l|c|c|c|c|c|} 
Valuta & Budget 14 & Budget 13 & Budget 12 & Disp./bud. 12 & Bud.disp. af \\
\hline DKK & 2.438 .000 & 6.230 .000 & 6.320 .000 & $80 \%$ & $\begin{array}{c}\text { NSK/MR- } \\
\text { SAM }\end{array}$
\end{tabular}

Formål

Formålet med budgetposten er at understøtte gennemførelsen af EU's Østersøstrategi og den Nordlige Dimension på områder af særlig nordisk nytte, at fremme samarbejdet med øvrige regionale organisationer og andre relevante aktører samt at støtte grænseregionalt samarbejde mellem Norden og nabolandene. 
Ministerrådet bidrager til gennemførelse af konkrete projekter i handlingsplanen for EU's Østersøstrategi, både som projektleder og som deltager. Endvidere bidrager ministerrådet til at sikre synlighed og opmærksomhed om Østersøstrategien gennem organisering og deltagelse i seminarer og konferencer om temaer af relevans for strategien.

Den Nordlige Dimension udgør den overordnede ramme for Nordisk Ministerråds samarbejde med Nordvestrusland. Nordisk Ministerråd arbejder gennem tre af partnerskaberne under den Nordlige Dimension: Partnerskabet for Sundhed og Socialt velbefindende med indsatser især rettet mod bekæmpelse af menneskehandel og smitsomme sygdomme (HIV/AIDS, tuberkulose), den Nordlige Dimensions Miljøpartnerskab, hvor den nordiske indsats gennemføres af NEFCO (Nordic Environment Finance Cooperation. Nordisk Ministerråd), den Nordlige Dimensions Partnerskab for Kultur, hvor NMR i perioden 20112013 havde påtaget sig værtskabet for sekretariatet.

Ministerrådet koordinerer og udveksler information med øvrige regionale organisationer såsom Østersørådet, Barentsrådet og Arktisk Råd i overensstemmelse med MRSAMs retningslinier vedtaget i september 2005.

Budgetposten kan endvidere anvendes til støtte af grænseregionalt samarbejde på tværs af regionen, også inklusive partnere i Polen og Tyskland.

Prioriteringer i Indsatser, som understøtter gennemførelsen af EU's 2014 Østersøstrategi og den Nordlige Dimension, er prioriteret:

- Gennemførelse af indsatser til understøttelse af EU's Østersøstrategi.

- Gennemførelse af indsatser til understøttelse af den Nordlige Dimension.

- Fortsat udvikling af samarbejdet med øvrige regionale råd og organisationer, herunder EU, Østersørådet, Barentsrådet, Arktisk Råd samt Helcom og Baltic 
Development Forum.

Styrkelse af det grænseregionale samarbejde i Østersøregionen, inklusive samarbejde med Polen og Tyskland.

6-0960-1 NGO-verksamhet i Östersjöregionen

\begin{tabular}{|l|c|c|c|c|c|} 
Valuta & Budget 14 & Budget 13 & Budget 12 & Disp./bud. 12 & Bud.disp. af \\
\hline DKK & 6.231 .000 & 6.133 .000 & 6.025 .000 & $80 \%$ & $\begin{array}{c}\text { NSK/MR- } \\
\text { SAM }\end{array}$
\end{tabular}

Formål

Ministerrådets NGO-program har som overordnet formål at understøtte styrkelse af civilsamfundet i Østersøregionen Programmet er et centralt instrument i Ministerrådets samarbejde i Østersøregionen.

Ministerrådets NGO-program for Østersøregionen støtter projekter, der fremmer kapacitetsopbygning og netværksdannelse gennem samarbejde mellem NGOer fra de nordiske lande, de baltiske lande og Polen samt Nordvestrusland og Hviderusland, indenfor en række områder såsom eksempelvis demokratiudvikling, miljø, kultur og menneskerettigheder.

Budgetposten finansierer endvidere nordisk-baltiske NGO-samarbejde indenfor en ramme på 1 MDKK. Dette program administreres af Nordisk Ministerråds kontorer i Estland, Letland og Litauen.

Prioriteringer i - Programmet lägger vikt på hållbarhet och resultatin2014 riktning

- Gennemførelse af 1 ansøgningsrunda 
6-5280-2 Nopef

\begin{tabular}{|l|c|c|c|c|c|} 
Valuta & Budget 14 & Budget 13 & Budget 12 & Disp./bud. 12 & Bud.disp. af \\
\hline DKK & 14.938 .000 & 16.053 .000 & 15.882 .000 & $0 \%$ & $\begin{array}{c}\text { NSK/MR- } \\
\text { SAM }\end{array}$
\end{tabular}

Formål

Nopef bliver en trust fund under NEFCO fra og med

1. januar 2014 og nedlægges dermed som en selvstændig institution.

Nopef har som syfte att som ett led i globaliseringen stärka nordiska små och medelstora bolags (SME) internationella konkurrenskraft genom att bevilja villkorslån till förstudier och förberedande aktiviteter inför internationella etableringar och investeringar utanför EU och Efta.

Nopef stöder projekt som bedöms att ha starka förutsättningar till kommersiell realisering och som främjar grön tillväxt, innovation, nordisk spetskompetens samt hälsa och välfärd. Nopef skall utveckla och stärka samarbetet med nordiska och nationella organisationer genom att erbjuda en unik och specialiserad produkt för nordiska tillväxtbolag.

Nopef bidrar med ett konkret riskavlyft i en tidig fas av nordiska SME-bolags internationalisering, och skall genom verksamheten agera som brobyggare mellan forskning \& utveckling och kommersialiseringsstadiet. Nopef samverkar här med andra nordiska finansieringsinstitutioner, näringspolitiska och exportfrämjande organisationer samt med aktörer inom den privata sektorn.

Genom ett aktivt informationsutbyte kan Nopef vägleda SME-bolagen och bidra med kunskap om nya och framväxande marknader samt ge tillgång till ett brett kontaktnätverk. Nopefs medverkan ger bolagen ökade resurser för överföring av nordisk kompetens och teknologi, före- 
tagskultur, värderingar och CSR. Vidare bidrar Nopefs deltagande till en effektiverad projektuppföljning och utgör en kvalitetsstämpel för företagens internationaliseringsprojekt.

Prioriteringer i Nopef skall fokusera på internationalisering av nor2014 diska SME-bolag inom kunskapsintensiva framtidsbranscher som bl.a. Cleantech, ICT, nano- och bioteknologi, material- och processteknik, Life Science, hälsa och välfärd samt klimat och miljö. Nopef prioriterar samnordiska projekt där det ingår aktörer från två eller flera nordiska länder och som bidrar till att skapa nordiska nätverk och allianser i projektländerna.

- Grön tillväxt och miljöteknik: projekt inom luft-, vatten- och avloppsteknik, avfallshantering, återvinning, förnybar energi, energieffektivisering, material- och processteknik, boende och infrastruktur.

- Innovation och spetskompetens: internationalisering av nordiska SME-bolag som kommersialiserat nya produkter, tjänster, produktionsprocesser eller affärsmodeller, samt tillväxtbolag med unik kompetens inom sitt verksamhetsområde.

- Hälsa och välfärd: internationella satsningar inom hälsa- och sjukvård, medicinsk teknik, bioteknologi, medicintekniska produkter, hjälpmedel samt arbetssäkerhet och -miljö.

- Förbättra SME-bolagens tillgång till nya och krävande tillväxtmarknader genom ett ekonomiskt riskavlyft i en krävande och riskfylld fas av internationaliseringen.

- Bidra till en kvalitativt bättre förstudie och ett starkare beslutsunderlag inför investeringar och affärsetableringar i Nopefs geografiska målområden.

- Skapa ökade förutsättningar för överföring av nordisk kompetens och teknologi, företagskultur, värderingar och CSR vid företagsetableringar i Nopefs geografiska målområden.

- Öka Nopefs synlighet bland Nordiska SME-bolag genom att aktivt delta i relevanta företagsseminarier och nätverk, samt genom ett utökat samarbete med 
nordiska aktörer inom det näringspolitiska området.

Ledelse og Planlagte udgifter 2014: $229000 €$

adm. Faktiske udgifter 2012: $273126 €$

Sekretariats- NEFCO

funktion

6-0970-3 Ministerrådets kontor i Nordväst Ryssland

\begin{tabular}{|l|c|c|c|c|c|} 
Valuta & Budget 14 & Budget 13 & Budget 12 & NMR fin. 12 & Bud.disp. af \\
\hline DKK & 9.383 .000 & 10.244 .000 & 10.043 .000 & $100 \%$ & Institutionen
\end{tabular}

Formål Budgetposten finansierer Nordisk Ministerråds kontor i Nordvestrusland: Skt. Petersborg med tilhørende kontaktcentre i Murmansk, Petrozavodsk og Arkhangelsk, samt kontoret i Kaliningrad, som fra 2014 administrativt er underlagt Skt. Petersborg kontoret.

Kontoret har en central rolle for Ministerrådet i gennemførelsen af retningslinjerne for samarbejdet med Nordvestrusland. Kontoret er en del af Nordisk Ministerråds sekretariat og arbejder sammen med alle relevante fagministerråd og nordiske institutioner. Kontoret i Nordvestrusland har en afgørende rolle i Nordisk Ministerråds samarbejde med Nordvestrusland og medvirker til opbygning af netværk og udvikling af samarbejde med såvel regionale som føderale aktører i Rusland og med andre internationale organisationer. Kontoret arbejder tæt sammen med Nordisk Ministerråds fagministerråd og bistår fagministerrådene i gennemførelsen af samarbejdsaktiviteter. Kontoret har endvidere tæt samarbejde med de nordiske landes generalkonsulater i Nordvestrusland og ambassader i Moskva og medvirker til skabelse af synergi i samarbejdet med landenes repræsentationer i Rusland om profilering af Norden indenfor alle sektorer. 
Kontoret fremmer og udvikler Ministerrådets program for Kundskabsopbygning og netværk, som er det centrale instrument for samarbejdet. Derudover medvirker kontoret i udvikling af både det nordisk-russiske NGO samarbejde og NGO-samarbejdet i Østersøregionen.

Kontoret er ansvarlige for administration af en række delprogrammer og projekter under Kundskabsopbygning og netværksprogrammet samt projekter med oprindelse i fagministerrådene. Kontoret varetager endvidere administration af øvrige ministerråds aktiviteter i Nordvestrusland og medvirker til implementering af ministerrådets aktiviteter relateret til den Nordlige Dimension og EU's Østersøstrategi. Kontoret medvirker i større projekter, herunder EU-projekter, som partner eller administrator.

Prioriteringer i Kontoret skal i 2014 fortsat udvikle det nordisk-russiske 2014 samarbejde med udgangspunkt i de nye retningslinjer samt deltage i og bidrage til gennemførelse af projekter og programmer.

- Facilitering og videreudvikling af det nordisk-russiske samarbejde i koordination med relevante fagministerråd.

- Bidrage til implementering af den Nordlige Dimension på projektniveau, herunder i samarbejde med de øvrige regionale organisationer i Nordeuropa.

- Gennemførelse af indsatser indenfor programmet for Kundskabsopbygning og netværk med udgangspunkt i de nye retningslinjer.

- Udvikling af NGO-samarbejdet i Østersøregionen, herunder inddragelse af partnere fra Barentsregionen.

- Udvikling af nordisk-russisk-baltisk samarbejde på relevante områder, særligt i forbindelse med den Nordlige Dimension og EU's Østersøstrategi og sammen med NMRs kontorer i Estland, Letland og Litauen.

- Aktiviteter indenfor formandskabsprogrammet i tæt samarbejde med Islands formandskab.

- Nordenfremmende indsatser i tæt samarbejde med de nordiske landes repræsentationer i Rusland. 


\section{6-0810-3 Ministerrådets kontor i Estland, Lettland och Litauen}

\begin{tabular}{|l|c|c|c|c|c|} 
Valuta & Budget 14 & Budget 13 & Budget 12 & NMR fin. 12 & Bud.disp. af \\
\hline DKK & 11.694 .000 & 11.521 .000 & 11.295 .000 & $100 \%$ & Institutionen
\end{tabular}

Formål

Budgetposten finansierer Nordisk Ministerråds kontorer i Riga, Vilnius og Tallinn, herunder infopunktet i Tartu, Estland.

Kontorerne har en central rolle for Ministerrådet i gennemførelsen af retningslinjerne for samarbejdet med Estland, Letland og Litauen. Kontorerne er en del af Nordisk Ministerråds Sekretariat og repræsenterer ministerrådet overfor myndigheder og organisationer i de baltiske lande. Kontorerne bidrager til at udvikle netværk og nye kontakter på politisk niveau i tæt koordination med relevante fagministerråd. Kontorerne bistår landene, fagministerrådene, de nordiske institutioner og sekretariatet $\mathrm{i}$ København med udvikling af fælles nordisk samarbejde med de baltiske lande. Kontorerne har tæt samarbejde med de nordiske landes ambassader i Tallinn, Riga og Vilnius og medvirker til at skabe synergi i samarbejdet med landenes repræsentationer om profilering af Norden indenfor alle sektorer.

Kontorerne medvirker til at udvikle NGO-samarbejdet mellem Norden og de baltiske lande og NGO-samarbejdet i Østersøregionen. Kontorerne medvirker i samarbejde med de baltiske lande om demokratifremmende projekter i Hviderusland, blandt andet støtten til European Humanities University i Vilnius. Kontorerne deltager i Ministerrådets arbejde for implementering af handlingsplanen for EU's Østersøstrategi og bidrager til ministerrådets arbejde indenfor rammerne af den Nordlige Dimension. Sammen med NMRs kontor i Nordvestrusland bidrager kontorerne til udvikling af nordisk-baltisk-russisk samarbejde.

Alle tre kontorer deltager som partner eller administrator i større projekter, herunder EU-projekter. Kontorerne med- 
virker i udvikling og gennemførelse af de fælles nordiskbaltiske mobilitetsprogrammer for offentlig administration, erhvervssamarbejde og kultur. Kontoret i Vilnius bistår sekretariatet i København med udvikling og administration af ministerrådets aktiviteter i forhold til Hviderusland, herunder EHU og EU-programmet CSSB.

Prioriteringer i Kontorerne skal i 2014 fortsat udvikle det nordisk2014 baltiske politiske samarbejde med udgangspunkt i de nye retningslinjer samt deltage i og bidrage til gennemforelse af projekter og programmer.

- Facilitering og videreudvikling af det nordisk-baltiske samarbejde i koordination med relevante fagministerråd.

- Bidrage til gennemførelse af EU's Østersøstrategi på projektniveau samt i NMRs arbejde for synliggørelse af strategien.

- Nordisk-baltiske mobilitetsprogrammer og udvikling af NGO-samarbejdet i Østersøregionen.

- Udvikling af nordisk-baltisk-russisk samarbejde, særligt relateret til EU's Østersøstrategi og den Nordlige Dimension.

- Aktiviteter indenfor formandskabsprogrammet i tæt samarbejde med Islands formandskab.

- Nordenfremmende indsatser i tæt samarbejde med de nordiske landes ambassader og andre relevante aktører.

\section{6-0910-1 Politiska initiativ}

\begin{tabular}{|l|c|c|c|c|c|} 
Valuta & Budget 14 & Budget 13 & Budget 12 & Disp./bud. 12 & Bud.disp. af \\
\hline DKK & 0 & 986.000 & 1.142 .000 & $80 \%$ & $\begin{array}{c}\text { NSK/MR- } \\
\text { SAM }\end{array}$
\end{tabular}

Formål

Budgetposten er nedlagt og sammenlagt med budgetpost 5-1021-1 Internationale aktiviteter. 
6-0850-1 Internationellt samarbete

\begin{tabular}{|l|c|c|c|c|c|} 
Valuta & Budget 14 & Budget 13 & Budget 12 & Disp./bud. 12 & Bud.disp. af \\
\hline DKK & 1.727 .000 & 0 & 0 & $0 \%$ & $\begin{array}{c}\text { General- } \\
\text { sekretæren }\end{array}$
\end{tabular}

Formål

Budgetposten finansierar initiativ och verksamhet i förbindelse med nya politiska utmaningar i Nordens närområden och resten av världen. Huvudvikt skall läggas vid nordenfrämjande verksamhet av tvärsektoriell karaktär utanför Norden. Detta för att ha den nödvändiga beredskapen att kunna agera på ad hoc - präglade initiativ för profilering och främjande av den nordiska modellen. I hög grad anslås medel till kontaktskapande och utvecklingsverksamhet där samnordiska satsningar prioriteras framom bilaterala. Utredningar, informationsmaterial och konferenser med betydelse för det nordiska samarbetet prioriteras.

Prioriteringer i Afhænger af den politiske udvikling.

2014

\section{6-0870-1 Arktiskt samarbetsprogram}

\begin{tabular}{|l|c|c|c|c|c|} 
Valuta & Budget 14 & Budget 13 & Budget 12 & Disp./bud. 12 & Bud.disp. af \\
\hline DKK & 9.335 .000 & 9.688 .000 & 9.717 .000 & $95 \%$ & $\begin{array}{c}\text { NSK/MR- } \\
\text { SAM }\end{array}$
\end{tabular}

Formål

Ministerrådets overordnede innsats i Arktis styres gjennom 3-årige arktiske samarbeidsprogrammer. Samarbeidsprogrammet "Bærekraftig utvikling i Arktis" varer fra 2012-2014. Formålet med dette tverrsektorielle programmet er å fokusere på og understøtte de områder hvor Norden har felles interesser og utfordringer i forhold til Arktis. Med den arktiske befolkningen i sentrum tar samarbeidsprogrammet sikte på å styrke innsatser for arktiske befolkningers fremtidige muligheter til å leve og virke i Arktis. 
Det arktiske samarbeidsprogrammet er rammen og instrumentet for dette arbeidet. Programmet supplerer de øvrige innsatser under ministerrådets internasjonale samarbeid og i de respektive fagministerråd. 3 mio DKK er øremerket utvikling av nye, nordiske politiske initiativ.

Initiativene og aktivitetene som understøttes av det arktiske samarbeidsprogrammet har utgangspunkt i de nordiske landenes strategier for regionen og er samtidig $\mathrm{i}$ overensstemmelse med arbeidet $\mathrm{i}$ andre arktisk relaterte fora som Arktisk Råd, Barentsrådet, EU m.fl.

Prioriteringer i Det arktiske samarbeidsprogrammet for 2012-2014 har 2014 som overgripende tema «befolkningen i sentrum».

Programmets innsatsområder har fem ulike tema som omfatter:

1) Arktiske befolkninger og deres levekår, helse og samfunnsutfordringer

2) Arktisk miljø og natur

3) Klimaspørsmål

4) Bærekraftig næringsutvikling og utvikling av en grønn næringsutvikling i Arktis

5) Utvikling og kompetanseutvikling av lokalbefolkninger i Arktis.

Aktiviteter med arktisk og nordisk medvirkning innenfor rammene av det arktiske samarbeidsprogrammets målsettinger, innsatsområder og kriterier.

Aktiviteter som er i tråd med aktuelle politiske prioriteringer, herunder i ministerrådene og i landenes arktiske strategier mv. 


\section{6-0950-2 EHU/Vitryssland}

\begin{tabular}{|l|c|c|c|c|c|} 
Valuta & Budget 14 & Budget 13 & Budget 12 & Disp./bud. 12 & Bud.disp. af \\
\hline DKK & 4.432 .000 & 4.662 .000 & 4.780 .000 & $82 \%$ & $\begin{array}{c}\text { NSK/MR- } \\
\text { SAM }\end{array}$
\end{tabular}

Formål

Nordisk Ministerråds aktiviteter i forhold til Hviderusland styres af retningslinjerne som godkendtes af NMR i 2010 og er i kraft i 2011-2013. På denne baggrund er budgettet til aktiviteter i forhold til Hviderusland forøget. Fokus er først og fremmest på støtte til demokratiudvikling, som er blevet endnu vigtigere efter den negative udvikling som indtraf efter præsidentvalget i december 2010. Aktiviteterne udvikles i tæt koordination med de nordiske landes bilaterale aktiviteter og i tæt samarbejde med øvrige donororganisationer.

EHU Trust Fondens hidtidige mandat udløb med udgangen af 2013, og en ekstern evaluering af fondens aktiviteter og drift er blevet gennemført. På baggrund af en anbefaling fra Assembly of Donors besluttede Nordisk Ministerråd i juli 2013 at forlænge mandatet til udgangen af 2016.

Budgetposten finansierer Nordisk Ministerråds bidrag til støtte for det hviderussiske eksiluniversitet European Humanities University (EHU) i Vilnius for herigennem at bidrage til at fremme en demokratisk samfundsudvikling i Hviderusland. Støtten til EHU foregår i tæt samspil med EU-kommissionen, som er den største bidragyder til EHU, den litauiske regering samt øvrige donorer, herunder det amerikanske State Department. Nordisk Ministerråds støtte til EHU vil blive kanaliseret gennem den Trust Fund, som ministerrådet etablerede i 2008. Fonden styres af NMR og sikrer gennemsigtighed om anvendelsen af donorstøtten til EHU.

Øvrige aktiviteter under denne budgetpost er støtte til øvige projekter, der kan bidrage til at fremme en demo- 
kratisk samfundsudvikling i Hviderusland. Endvidere kan budgetposten finansiere medarbejderressourcer på NMRs kontor i Vilnius, som bistår sekretariatet i København med udvikling af projekter relateret til Hviderusland.

Prioriteringer i Udvikling af initiativer i forhold til Hviderusland i tæt 2014 koordination med de nordiske landes bilaterale aktiviteter og i tæt samarbejde med de øvrige donororganisationer.

- Fortsat støtte til European Humanities University (EHU) i Vilnius, Litauen.

- Effektiv drift og administration af Trust Fonden for EHU.

- Udvikling af initiativer til fremme af en demokratisk samfundsudvikling i Hviderusland.

6-0990-1 Samarbetet med Nordens grannar i Väst

\begin{tabular}{|l|c|c|c|c|c|} 
Valuta & Budget 14 & Budget 13 & Budget 12 & Disp./bud. 12 & Bud.disp. af \\
\hline DKK & 1.578 .000 & 2.553 .000 & 2.708 .000 & $80 \%$ & $\begin{array}{c}\text { NSK/MR- } \\
\text { SAM }\end{array}$
\end{tabular}

Formål

Nordisk ministerråd ønsker å øke samarbeidet med Nordens naboer i vest, med hovedvekt på Canada. Budsjettposten finansierer utviklingen av samarbeidsinitiativ og konkrete prosjekter i de temaområder som nevnes i

NMRs retningslinjer for samarbeidet med naboene i vest, d.v.s. det marine området; næring, miljø, klima og energi; utdanning, forskning og innovasjon; kultur; og helse. Budsjettposten skal primært brukes som såkornsmidler og ikke som kontinuerlig finansiering. Initiativene koordineres med de øvrige relevante innsatser i Nordisk ministerråd.

Prioriteringer i I 2014 prioriteres oppfølgingen av NMRs retningslinjer 2014 for samarbeidet med naboerne i vest 2012-2016. 


\section{Samarbejdsministrene}

\section{Generel indledning}

Generelt Samarbejdsministrene har det overordnede ansvar for det nordiske samarbejde. Det betyder, at de fleste af de budgetposter som samarbejdsministrene har ansvaret for er af tværgående karakter. Udover at være af tværgående karakter spænder budgetposterne også over en meget bred vifte af aktiviteter, herunder bl.a. poster af teknisk administrativ karakter såsom bidrag til Vestnorden, tjenestemandsudbytte og Generalsekretærens dispositionsreserve.

Posten Holdbart Norden fordeles af NSK og samarbejdsministrene hen over året med baggrund i henholdsvis formandskabsprogrammet og i strategien for bæredygtig udvikling, sidstnævnte i dialog med fagministerrådene.

De resterende poster har primært et kommunikations- og formidlingsperspektiv, som disponeres af generalsekretæren.

Udmøntning af Den total budgetramme i 2014 reduceres med $5 \%$ i forbesparelse i hold til 2013 (i 2013 priser). Dette svarer til 49,3 MDKK. budget 2014 Hvis besparelserne på budgetposter i 2014 er sammenlignet med de budgetposter som tilhørte rammen i 2013 er der 4,9 MDKK af dette beløb som fordeles på rammen "Samarbejdsministrene". Nærmere deles dette beløb op i 3,8 MDKK som skæres på Sekretariatets andel i rammen $(4,6 \%)$ og 1,1 MDKK (3,8 \%) på Fællesaktiviteter.

Der er pålagt administrative besparelse på 1 MDKK på samarbejdsministrenes ramme. Den vil blive udmøntet ved, at der i sekretariatet nedlægges en afdelingschefstilling. Mindre besparelser på Hallo Norden og Norden i Fokus vil blive sikret via kontrakterne med forvaltningsorganerne i 2014. Pro rata reduktion på alle budgetposter er 3,9 MDKK.

Rammen er $\mathrm{i}$ alt efter reduktion og omplacering af bud- 
getposten Internationale aktiviteter fra Samarbejdsministrenes ramme til Nabopolitik, se nærmere bemærkninger hernedenfor, 105,746 MDKK i 2013 prisniveau.

Andre ændringer på budgetpostniveau er på følgende budgetposter:

\section{Hallo Norden}

På NSK møde i juni 2010 blev det besluttet at anvende 300 TDKK til at oprette kontaktpunkt for Hallo Norden på Åland i en forsøgsperiode i 2 år, 2011 og 2012. I 2011 bestemte NSK at oprette kontaktpunkt på Færøerne med forsøgsperiode i årene 2012 og 2013, og blev det finansieret med 200 TDKK pr. år med uforbrugte midler fra tidligere år. Sidste år bestemt NSK at forlænge forsøgsperioden på Åland om 1 år med 200 TDKK. Midler hertil finansieredes med 100 TDKK henholdsvis fra Grænsehindringer og Grænsehindringsforum. Kontaktpunktet på begge steder skal forsætte fremover og at ovenanført bevilling på total 200 TDKK i 2013 forsætter. De efterstående 200 TDKK finansieres fra Tjänestemannautbyte. Desuden er der bestemt at forhøje bevillingen med 50 TDKK til begge steder, med finansiering fra Grænsehindringsforum.

Tjänestemannautbyte

Som led $i$ at finde finansiering til Hallo Norden som nævnt ovenfor, er budgetposten reduceret med 200 TDKK

Internationale aktiviteter

Generelsekretæren foreslår at budgetposten sammenlægges med budgetposten Politiske initiativer og at disse to poster danner en ny budgetpost Internationellt samarbete under rammen Nabopolitik. Disse to poster er forholdsvis små og formålene er lignende.

Ministerrådets styringsdokumenter
Som en konsekvens af rammens tværgående karakter er der ikke ét, men flere dokumenter, der styrer aktiviteterne under rammen. Af styringsdokumenter kan nævnes: - Formandskabsprogrammet 
Resumé af Ministerrådets resultater i 2012
- Bæredygtig udvikling - en ny strategi for Norden

- Nordisk Ministerråds kommunikationstrategi

Hållbar utveckling 2012

Året var präglat av två stora satsningar inom hållbar utveckling: revideringen av den nordiska strategin för hållbar utveckling samt deltagandet i FN:s Rio+20 konferens. Den nya nordiska hållbarhetsstrategin, Ett gott liv $i$ ett hållbart Norden, utarbetades av den nordiska expertgruppen för hållbar utveckling i tätt samarbete med ministerrådets facksektorer. Det togs också fram ett nytt nordiskt nyckelindikatorset för att följa utvecklingen i Norden. Nordiska rådet godkände den nya strategin med det förbehåll att ministerrådet framlägger sektorernas konkreta åtgärder som ett ministerrådsförslag i 2013.

NMR deltog aktivt i Rio+20 konferensen i juni 2012 och arrangerade ett officiellt sidoarrangemang och tre temaseminarier. Sidoarrangemanget var en ministerdialog, Seizing ecolabelling and Sustainable Public Procurement opportunities, som samlade ministrar från Norden och Sydamerika för att diskutera miljömärkning och hållbar offentlig upphandling inom ramen för grön ekonomi och hållbar utveckling. Arrangemanget hade en tydlig koppling till ett samarbetsprojekt med FN:s miljöprogram (UNEP), som främjar regionalt samarbete inom dessa teman i Brasilien, Chile, Argentina, Uruguay och Paraguay, och därmed förstärkte arrangemanget även ländernas politiska engagemang och ägarskap i projektet.

Temaseminarierna hade fokus på olika dimensioner i hållbar utveckling, nämligen mat $i$ en global hållbarhetskontext (From New Nordic Food to New Rural Development), jämställdhet och social inkludering (Gender Equality is Sustainability) och ekosystemtjänster och naturkapitalets roll (Natural capital in green economy - from regional insights to a global partnership). I tillägg delfinansierade NMR två workshopar och bidrog innehållsmässigt till flera arrangemang med nordiska presentationer. NMR hade också en infomonter i Rio+20 konferensens pavil- 
jongområde, med bl.a. en nordisk energiutställning.

I tillägg fortsatte implementeringen av strategin 20092012 inom fyra prioriterade områden: klimat och förnybar energi; hållbar konsumtion och produktion; nordisk välfärdsstat som verktyg för hållbar utveckling; samt utbildning och forskning, befolknings deltagande och lokala hållbarhetsstrategier. Det beviljades projektstöd till två större projekt, varav det ena hade fokus på hållbar akvakultur och det andra på utbildning.

Arbetet med att undanröja gränshinder i Norden Merparten av allt gränshinderarbete på NMRs sker idag inom ramen för "Gränshinderforum" (GF), där NMRs är sekretariat för GF. Arbetet i förhållande till GF har främst handlat om att utreda och ta fram underlag rörande konkreta gränshinder, författa brev till myndigheter och ministrar, administrera större utredningar och projekt m.m.

I løbet af 2012 afsluttedes arbejdet $i$ en ekspertgruppe nedsat under EK-A og EK-S. Arbejdsgruppen gennemførte analysearbejde af 36 grænsehindringer og fremkom med løsningsforslag til en række af hindringerne på social- og arbejdsmarkedsområdet. Rapportens konklusioner danner nu grundlag for en række processer på arbejdslov og social- og helseområdet, der forventes at medføre, at en række konkrete grænsehindringer vil blive fjernet.

NMRs har också haft ett tätt samarbete med de nordiska informationstjänsterna, Hallo Norden samt de gränsregionala informationstjänsterna, och gränskommittéerna för att på så sätt försöka undanröja gränshinder i Norden. Under 2012 höll Gränshinderforum sitt årliga möte med HalloNorden och de regionala informationstjänsterna där man diskuterade samordning av gränshinder- och informationsarbetet samt priortering av gränshinder.

En arbetsgrupp tillsattes i maj 2012 att utreda Gränshinderforums arbete fram till nu samt utveckla en handlingsplan för det fortsatta gränshinderarbetet med start 2014. 
Handlingsplanen kommer att presentera och godkännas på Nordiska Rådets Session i oktober 2013.

Kommunikation och förmedling 2012

Samarbetsministern för 2012 års ordförandeland, Norge, Rigmor Aasrud, lyfte i sin sessionsrapport särskilt upp den stora kommunikationssatsningen på Bok \& Biblioteksmässan i Göteborg. Det är den största bokmässan i Norden, och 2012 hade man valt Norden som tema för mässan. Med särskilt stöd av kulturministrarna kunde Nordiska ministerrådet i ett omfattande och tvärsektoriellt samarbete bygga en central temamonter med över 70 programpunkter om allt från rena litterära möten till politiska debatter om till exempel kulturell mångfald och identitet $\mathrm{i}$ Norden.

Strategin att uppträda på arenor för politisk debatt medförde att vi återigen, i arrangemang av Norden i Fokus, fanns på plats på Folkemötet på Bornholm. Där fokuserades på prioriterade debattämnen som Framtidens hälsosektor, En ny nordisk skola och Tillväxt i kreativa näringar.

Som ett stöd för olika former av PR togs en imagefilm fram, Cool Nordic. Den hade premiär på de nordiska ambassaderna i Berlin och visades därefter på ett flertal festivaler samt distribuerades till ambassader, konsulat, parlament, kulturhus med flera vidareförmedlare.

Webutvecklingen tog stora steg under 2012. Hemsidan, www.norden.org, fick en ny så kallad responsive design, vilket innebär att den kan anpassas till olika typer av digitala mottagare; mobilder, i Pads med flera. En ny struktur för Hallå Norden togs fram, och nätfrågorna till organisationen om arbete, studier och förflyttning mellan de nordiska länderna var fortsatt de mest angelägna för de medborgare i Norden som valde att söka information via www.norden.org.

Modernisering och effektivisering blev också nyckelorden 
för arbetet med att förmedla den kunskap som genereras i det nordiska samarbetet i form av rapporter, böcker etc. Tack vare en övergång till print-on-demand kunde 60 ton papper slängas, och genom att etablera samarbete med digitala plattformar som Google Books, ebrary, EBSCO med flera kunde vi på kort tid minst tiodubbla sökbarheten. Tack vare en påbörjad utgivning av e-böcker nådde vi detaljhandeln och via e-lån folkbiblioteken. En undersökning påvisade fördelarna med att publicera i Open Access, varpå ett samarbete med berörda institutioner startade med målet att under kommande år öppet tillgängliggöra mycket av det som publiceras tack vare stöd från Nordiska ministerrådet.

\begin{tabular}{llrrrr} 
& & Budget & Budget & \multicolumn{2}{c}{ Difference } \\
& & $\mathbf{2 0 1 4}$ & $\mathbf{2 0 1 3}$ & \multicolumn{1}{c}{+ - } & \% \\
\hline Samarbejdsministrene (TDKK) & $\mathbf{1 0 7 . 3 6 2}$ & $\mathbf{1 1 1 . 3 6 4}$ & $\mathbf{- 4 . 0 0 2}$ & $\mathbf{- 3 , 6 \%}$ \\
& Ministerrådets sekretariat (NMRS) & 78.204 & 80.804 & -2.600 & $-3,2 \%$ \\
$5-0180-3$ & Ministerrådets sekretariat (NMRS) & 78.204 & 80.804 & -2.600 & $-3,2 \%$ \\
& Nordisk Ministerråds faellesaktiviteter & 29.158 & 30.560 & -1.402 & $-4,6 \%$ \\
$5-0410-4$ & Föreningarna Nordens Förbund & 3.244 & 3.309 & -65 & $-2,0 \%$ \\
$5-0425-4$ & Bidrag til Västnorden & 729 & 744 & -15 & $-2,0 \%$ \\
$5-0435-1$ & Generalsekreterarens disponeringsreserv & 414 & 422 & -8 & $-1,9 \%$ \\
$5-0460-1$ & Holdbart Norden & 3.042 & 3.102 & -60 & $-1,9 \%$ \\
$5-1011-1$ & Informationsaktiviteter & 5.086 & 5.188 & -102 & $-2,0 \%$ \\
$5-1012-1$ & Norden i Fokus & 4.423 & 4.541 & -118 & $-2,6 \%$ \\
$5-1021-1$ & Internationale aktiviteter & 0 & 740 & -740 & - \\
$5-1030-2$ & Hallo Norden & 5.823 & 5.679 & 144 & $2,5 \%$ \\
$5-1035-1$ & Grænsehindringer & 0 & 3.911 & -3.911 & - \\
$5-1036-2$ & Grænsehindringsråd & 5.076 & 0 & 5.076 & - \\
$5-1050-2$ & Tjänstemannautbyte & 1.321 & 1.554 & -233 & $-15,0 \%$ \\
$5-2055-1$ & Gränshindersforum & 0 & 1.370 & -1.370 & -
\end{tabular}

\begin{tabular}{crrrr}
\hline Opdelt på kategorier & $\mathbf{1 0 7 . 3 6 2}$ & $\mathbf{1 1 1 . 3 6 4}$ & $\mathbf{1 0 0 \%}$ & $\mathbf{1 0 0 \%}$ \\
\hline Projektmidler & 12.965 & 19.274 & $12,1 \%$ & $17,3 \%$ \\
Programlignende aktiviteter & 12.220 & 7.233 & $11,4 \%$ & $6,5 \%$ \\
Institutioner & 78.204 & 80.804 & $72,8 \%$ & $72,6 \%$ \\
Organisationsbidrag & 3.973 & 4.053 & $3,7 \%$ & $3,6 \%$
\end{tabular}




\section{Sekretariatet}

\section{5-0180-3 Ministerrådets sekretariat (NMRS)}

\begin{tabular}{|l|c|c|c|c|c|} 
Valuta & Budget 14 & Budget 13 & Budget 12 & NMR fin. 12 & Bud.disp. af \\
\hline DKK & 78.204 .000 & 80.804 .000 & 79.220 .000 & $100 \%$ & Institutionen
\end{tabular}

Formål

Nordisk Ministerråds Sekretariat (NMRS) er et politisk sekretariat for Nordisk Ministerråd og vil gennem høj kompetence og effektivitet løse de opgaver, som de får i opdrag. NMRS bidrager på opdrag fra de nordiske landes regeringer, de selvstyrende områders landstyrer og på eget initiativ til at videreføre, forstærke og udvikle det nordiske samarbejde, samt fremme fælles nordiske interesser i en verden under stadig forandring.

Nordisk Ministerråd har en kommunikationsafdeling fælles med Nordisk råd. Kommunikationsafdelingen finansieres i forholdet 60/40 mellem Ministerrådet og Rådet.

Prioriteringer i Sekretariatet skal opfattes som en professionel, attraktiv 2014 arbejdsplads, med et arbejdsmiljø præget af medarbejdere som tager ansvar, viser engagement og integritet, har vilje og evne til nytænkning og samarbejde. Udvikling af kompetence, fysisk og psykosocialt arbejdsmiljø skal indgå som en integreret del af sekretariatets virksomhed. Sekretariatet skal lægge vægt på arbejdsmetoder, som bidrager til relevans og fokusering på de centrale opgaver. Nordisk nytte udvikles ved:

- Identificering og forberedelser af temaer med fælles nordisk betydning for politisk behandling i ministerråd og embedsmandskomitèer i et nært samarbejde med de ansvarlige nationale myndigheder.

- Gennem udredninger, seminarer og konferencer at give medlemslandene muligheder for at tage initiativ omkring relevante nordiske temaer

- At initiere og implementere politiske beslutninger, og bidrage til at evalueringer og resultater bliver rapporteret til de politiske beslutningsorganer. 
- Sikre kvalitet, kontinuitet og fremdrift i udførelse af sekretariatets arbejdsopgaver.

- Give kundskab og bidrage til øget interesse for det nordiske samarbejde både i og udenfor Norden gennem effektiv og målrettet informationsformidling. I denne sammenhæng er det vigtig at tydeliggøre resultaterne og konsekvenserne af det nordiske samarbejde, samt at synliggøre hvordan de nordiske erfaringer kan være et bidrag til samfundsudviklingen i Europa og verden udenfor Norden.

- Bidrage til at udvikle, modernisere og effektivisere det nordiske samarbejde.

\section{Nordiska ministerrådets Fællesaktiviteter}

5-0410-4 Föreningarna Nordens Förbund

\begin{tabular}{|l|c|c|c|c|c|} 
Valuta & Budget 14 & Budget 13 & Budget 12 & Disp./bud. 12 & Bud.disp. af \\
\hline DKK & 3.244 .000 & 3.309 .000 & 3.250 .000 & $100 \%$ & FNF
\end{tabular}

Formål

Att genom beviljningen till Föreningarna Nordens Förbund (FNF) bidra till en folklig förankring av det nordiska samarbetet, samt till en god kännedom om det nordiska samarbetet bland de nordiska medborgarna.

Beviljningen till FNF är ett allmänt verksamhetsbidrag. FNF tillvaratar samarbetet mellan Föreningarna Norden i de fem nordiska länderna, Färöarna, Grönland och Åland samt bidrar till att verksamheten vid de regionala informationskontoren drivs vidare under 2014.

Prioriteringer i - Nordiskt skolsamarbete 2014

- Stärkande av forstålese av grannspråken

- Dialog och samarbete med NMR och NR

- Gränshinder och den gemensamma nordiska arbetsmarknaden

- Arbete för att samla de nordiska sammenslutningsorganisationerna till ett nätverk 
5-0425-4 Bidrag till Västnorden

\begin{tabular}{|l|c|c|c|c|c|} 
Valuta & Budget 14 & Budget 13 & Budget 12 & Disp./bud. 12 & Bud.disp. af \\
\hline DKK & 729.000 & 744.000 & 731.000 & $100 \%$ & $\begin{array}{c}\text { General- } \\
\text { sekretæren }\end{array}$
\end{tabular}

Formål Bidraget anvendes til rejsestøtte til grønlandske embedsmænds deltagelse i det nordiske samarbejdet.

5-0435-1 Generalsekreterarens disponeringsreserv

\begin{tabular}{|l|c|c|c|c|c|} 
Valuta & Budget 14 & Budget 13 & Budget 12 & Disp./bud. 12 & Bud.disp. af \\
\hline DKK & 414.000 & 422.000 & 415.000 & $52 \%$ & $\begin{array}{c}\text { General- } \\
\text { sekretæren }\end{array}$
\end{tabular}

Formål Generalsekretærens dispositionsreserve er afsat til rådighed for generalsekretæren til at imødekomme specifikke behov. Reserven giver generalsekretæren mulighed for at igangsætte $\mathrm{fx}$ indledende projekter og undersøgelser, sætte fokus på særlige problemstillinger, dække uforudsete udgifter i forbindelse med afslutning af projekter mv. Generalsekretærens reserve skal derimod ikke benyttes til tillægsbevillinger til institutioner, embedsmandskomiteer eller sekretariatet til formål, som er prøvet i den ordinære budgetbehandling.

5-0445-1 Formandsskabspuljen

\begin{tabular}{|l|c|c|c|c|c|} 
Valuta & Budget 14 & Budget 13 & Budget 12 & Disp./bud. 12 & Bud.disp. af \\
\hline DKK & 0 & 0 & 6.022 .000 & $89 \%$ & $\begin{array}{c}\text { NSK/MR- } \\
\text { SAM }\end{array}$
\end{tabular}

Formål Budgetposten er nedlagt. 


\section{5-0460-1 Hållbart Norden}

\begin{tabular}{|l|c|c|c|c|c|} 
Valuta & Budget 14 & Budget 13 & Budget 12 & Disp./bud. 12 & Bud.disp. af \\
\hline DKK & 3.042 .000 & 3.102 .000 & 3.047 .000 & $94 \%$ & $\begin{array}{c}\text { NSK/MR- } \\
\text { SAM }\end{array}$
\end{tabular}

Formål

Budgetposten Hållbar Norden stimulerar samnordiska insatser inom hållbar utveckling. Ett gott liv $i$ ett hållbart Norden - Nordisk strategi för hållbar utveckling är den överordnade och tvärsektoriella ramen för Nordiska ministerrådets arbete. Allt arbete som görs inom ramen för Nordiska ministerrådet ska ha ett integrerat hållbarhetsperspektiv.

Nordiska ministerrådet ska bidra till att de nordiska länderna successivt fortsätter att förbättra välfärden och livskvaliteten för nuvarande och kommande generationer genom att skydda och tillvarata jordens förmåga att uppehålla liv i hela dess mångfald.

Strategin ger långsiktiga riktlinjer fram till 2025 inom följande fokusområden: den nordiska välfärdsmodellen, livskraftiga ekosystem, ett förändrat klimat, ett hållbart nyttjande av jordens resurser samt utbildning, forskning och innovation. Strategin kan också fungera som utgångspunkt för gemensamma inspel i internationella forum för hållbar utveckling.

De nordiska samarbetsministrarna har det övergripande ansvaret för hållbar utveckling. Ett framgångsrikt genomförande förutsätter också att de berörda fackministerråden tar ägarskap för det samnordiska hållbarhetsarbetet. Strategins gemensamma värdegrund och målsättningar ska integreras i fackministerrådens sektorsprogram och omsättas till konkreta åtgärder med mätbara mål.

Prioriteringer i Arbetet med hållbar utveckling ska fokusera på områden 2014 där Norden har gemensamma intressen och utmaningar 
och där det finns särskilt goda förutsättningar för att bidra till hållbar utveckling. Det nordiska samarbetet ska skapa ett mervärde och bidra till ökad kompetens och en mer effektiv resursanvändning.

Budgetposten Hållbar Norden används för aktiviteter som stödjer implementeringen av den nordiska strategin för hållbar utveckling. Dessa initiativ skall uppfylla kraven om nordisk nytta, vara tvärsektoriella och innovativa samt integrera de tre aspekterna av hållbar utveckling.

- Stödja implementeringen av den nordiska strategin för hållbar utveckling

- Följa utvecklingen i Norden genom de nordiska nyckelindikatorerna för hållbar utveckling

- Delta aktivt $\mathrm{i}$ implementeringen av Islands ordförandeskapsprioriteringar för hållbar utveckling, speciellt inom det tvärsektoriella området bioekonomi

- Engagera ministerrådets facksektorer för samarbetet om hållbar utveckling och genomföra ett s.k. verktygsprojekt för att underlätta sektorernas hållbarhetsintegrering

- Förstärka kommunikationsinsatser kring ministerrådets aktiviteter inom hållbar utveckling

- Delta aktivt i det internationella arbetet om hållbar utveckling, speciellt inom EU, UNECE, OECD och FN

- Följa upp FN:s konferens för hållbar utveckling Rio +20

\section{5-1011-1 Informationsaktiviteter}

\begin{tabular}{|l|c|c|c|c|c|} 
Valuta & Budget 14 & Budget 13 & Budget 12 & Disp./bud. 12 & Bud.disp. af \\
\hline DKK & 5.086 .000 & 5.188 .000 & 5.096 .000 & $83 \%$ & $\begin{array}{c}\text { General- } \\
\text { sekretæren }\end{array}$
\end{tabular}


Formål

\section{Prioriteringer i} 2014
Denna budgetpost är en del av verksamheten i Nordiska ministerrådets kommunikationsavdelning. Den stödjer det kommunikationsstrategiska arbetet, utvecklingen av kommunikationsområdet som sådant, nordiskt statistiskt arbete, översättnings- och tolkningsarbete samt övriga mediestrategiska satsningar. Ur denna budgetpost finansieras endast aktiviteter som berör Nordiska ministerrådet. (Kommunikationsavdelningen arbetar också för Nordiska rådet.)

Modernisering och effektivisering är parallellt med kvalitetshöjning viktiga mål för det kommunikationsstrategiska arbetet. Förutom att förbättra kommunikationsarbetet som sådant är kommunikation ett av de verktyg som kan bidra till hela verksamhetens utveckling. En förbättrad intern kommunikation, liksom stödet till kommunikationen och dialogen i det nordiska samarbetets nätverk bidrar till en tydligare och mer synlig bild av verksamhetens resultat och politiska ambitioner.

- Att implementera en ny kommunikationsstrategi

- Att ta vara på omvärldens intresse för det nordiska samarbetet genom att förekomma på arenor för politik och debatt inom och utanför Norden

- Att samordna, modernisera och effektivisera kommunikationsarbetet

- Fortsatt fokus på ökad tillgänglighet och nytta med hjälp av marknadsföring och förmedling i digitala kanaler av kunskap genererad i det nordiska samarbetet; rapporter, böcker, nordisk statistik etc.

- Att öka graden av service och medborgarnas tillgång till tjänster till via www.norden.org

- Att utveckla graden av kommunikationskompetens inom organisationen.

- Att bidra till en samsyn på syftet och möjligheterna med kommunikation som ett medel för verksamhetsutveckling. 
5-1012-1 Norden i Fokus

\begin{tabular}{|l|c|c|c|c|c|} 
Valuta & Budget 14 & Budget 13 & Budget 12 & Disp./bud. 12 & Bud.disp. af \\
\hline DKK & 4.423 .000 & 4.541 .000 & 4.461 .000 & $98 \%$ & $\begin{array}{c}\text { General- } \\
\text { sekretæren }\end{array}$
\end{tabular}

Formål

Norden i Fokus kontoren kommer under 2014 att fortsätta arbetet med styrka samarbetet mellan kontoren och Nordiska Ministerrådet. Det finns flera syften med det; modernisering, effektivisering och höjd grad av kvalitet. Arbetet ska fortsatt ske med den övergripande kommunikationsstrategin som utgångspunkt och med de profilerade frågorna i fokus. Därmed ska aktiviteter väljas som faller inom ramen för de fyra profileringsområden, som beskrivs i kommunikationsstrategin. Ordförandeskapets prioriteringar och de prioriterade insatsområdena Grön tillväxt och Hållbar nordisk välfärd ska också vara underlag i planeringen av årets aktiviteter.

De goda erfarenheterna av att uppträda på arenor för politisk debatt, som Almedalen, Folkmötet på Bornholm, Suomi Areena och Arendalsveckan, ska tas tillvara och utvecklas i hela Norden. Nya medier ska användas i samma eller ökat omfång. Samtidigt ska NIF agera med flexibilitet och snabbhet. Exempelvis har vissa av kontoren goda erfarenheter av att anordna aktiviteter kring ett av de nordiska ländernas val, vilket kommer att fortsätta. Verksamhetsplaneringen ska ske i dialog och direkt samarbete med sekretariatets kommunikationsavdelning. Uppföljning av aktiviteterna är en viktig del i rapporteringen av verksamheten.

Prioriteringer i 2014
- Nordensamordnade aktiviteter

- Synlighet på arenor för aktuell politisk debatt 
5-1021-1 Internationella aktiviteter

\begin{tabular}{|l|c|c|c|c|c|} 
Valuta & Budget 14 & Budget 13 & Budget 12 & Disp./bud. 12 & Bud.disp. af \\
\hline DKK & 0 & 740.000 & 727.000 & $72 \%$ & $\begin{array}{c}\text { General- } \\
\text { sekretæren }\end{array}$
\end{tabular}

Formål

Budgetposten er sammenlagt med posten Politiske initiativer (Internationalt samarbejde), og de danner en ny budgetpost Internationalt samarbejde under Internationalt samarbejdes ramme.

5-1030-2 Hallo Norden

\begin{tabular}{|l|c|c|c|c|c|} 
Valuta & Budget 14 & Budget 13 & Budget 12 & Disp./bud. 12 & Bud.disp. af \\
\hline DKK & 5.823 .000 & 5.679 .000 & 5.379 .000 & $98 \%$ & $\begin{array}{c}\text { General- } \\
\text { sekretæren }\end{array}$
\end{tabular}

Formål

Syftet med Hallå Norden är att underlätta privatpersoners och företags mobilitet i Norden. Detta skall ske genom att tillhandahålla information till privatpersoner och företag, för att underlätta dessas beslut om flytt, arbete, studier, etablering av företag etc. $i$ ett nordiskt grannland.

I huvudsak skall relevant information tillhandahållas via Nordiska ministerrådets och Nordiska rådets webbplats, www.norden.org, i andra hand skall personlig vägledning ske i de fall enskilda eller företag tar kontakt med Hallå Norden via webben, e-post, telefon, brev eller personliga besök.

Från och med 2014 avsätts fasta medel för finansiering av kontaktpunkter på Åland och Färöarna.

För att underlätta mobiliteten i Norden arrangerar Hallå Norden informationsseminarier för nationella tjänstemän på myndigheter som allmänhet och företag ofta tar kon- 
takt med inför en flytt, arbete, studier etc.

Hallå Norden skall också bygga nätverk med centrala personer på centralamyndigheter och departement / ministerier, och arrangera regelbundna möten med dessa $i$ syfte att dels hålla sig informerade om regelförändringar och politiska skeenden i länderna, dels för att själva informera om problem etc.

Prioriteringer i 2014

- Målriktad webinformation till yrkesgrupper som pendlar mycket

- Dialog och delaktighet av målgrupper via sociala medier

- Utveckling av gemensamma verktyg och processer för gränstjänster i syfte att möjliggöra systematisk dokumentation och förmedling rörande gränshinder

- Implementering av ny informationsstruktur för Hallå Nordens websidor

5-1035-1 Gränshinder

\begin{tabular}{|l|c|c|c|c|c|} 
Valuta & Budget 14 & Budget 13 & Budget 12 & Disp./bud. 12 & Bud.disp. af \\
\hline DKK & 0 & 3.911 .000 & 3.942 .000 & $80 \%$ & $\begin{array}{c}\text { General- } \\
\text { sekretæren }\end{array}$
\end{tabular}

Formål Budgetposterne for grænsehindringsarbejdet, 5-1035-1 Grænsehindringer og 5-2055-1 Gränshindersforum, er sammenlagt til en ny budgetpost, 5-1036-1, Gränshindringsråd fra og med 2014.

\section{5-1036-1 Grænsehindringsråd}

\begin{tabular}{|l|c|c|c|c|c|} 
Valuta & Budget 14 & Budget 13 & Budget 12 & Disp./bud. 12 & Bud.disp. af \\
\hline DKK & 5.076 .000 & 0 & 0 & $0 \%$ & $\begin{array}{c}\text { General- } \\
\text { sekretæren }\end{array}$
\end{tabular}


Med henblik på yderligere at styrke grænsehindringsarbejdet udvikles et Grænsehindringsråd med en ny strategi- og handleplan, som træder i kraft den 1. januar 2014. Grænsehindringsrådet erstatter det tidligere Grænsehindringsforum (budgetpost 5-2055-1) og budgetposten Gränsehinder (5-1035-1)

For at opnå dette får organisationen som mål

- at virke for et åbent og velfungerende fælles arbejdsmarked

- at skabe de bedste mulige forudsætninger for at nordiske virksomheder kan virke over grænserne i Norden

- $\quad$ så vidt muligt at sikre en ensartet gennemførelse af EU-regulering i Norden gennem en løbende dialog mellem de nordiske lande

- $\quad$ at virke for at landene, når nødvendigt, gennemfører høring med hinanden når nye eller ændrede regler foreslås med henblik på at undgå at nye grænsehindringer opstår,

Dette medfører at

- arbejdet kommer til at blive koblet tættere til den politiske ledelse i Nordisk Ministerråd ved at formandsskabslandet i Nordisk Ministerråd også kommer til at indehave formandsskabet i Grænsehindringsrådet

- generalsekretæren får en stærkere rolle i grænsehindringsarbejdet for ministerrådet

- Grænsehindringsrådet nationale repræsentanter får et tydeligt opdrag med at samarbejde med de aktører, der kan bidrage med at løse grænsehindringer for individer og virksomheder i Norden. Dette samarbejde omfatter bl.a. landenes departementer og myndigheder, parlamentarikere og de grænseregionale informationstjenester.

Den nye form for nordisk grænsehindringsarbejde kommer til at bidrage til et mere effektivt arbejde for at fjerne 
grænsehindringer og øge bevægeligheden i Norden.

Prioriteringer Grænsehindringsrådet vil søge at opnå resultater indenfor i 2014 de områder, der typisk har medført de største barrierer for mobilitet i Norden. I praksis antages det at medføre, at der vil blive fokuseres på

- forebyggelse af hindringer

- hindringer på social - og arbejdsmarkedet,

- hindringer uddannelsessektoren,

- hindringer på skatteområdet

- hindringer på næringslivsområdet

- at sikre bevægelighed for små- og mellemstore virksomheder

Ved forhandlingerne mellem Nordisk Ministerråd og Nordisk Råd om budgettet for 2014 er der opnået enighed om:

-at det avsätts 0,5 MDKK till en förstudie, för att närmare dokumentera behovet av nordiskt sammanhållen information på webben till små- och mellanstora företag som önskar rekrytera personal, etablera sig eller handla över gränserna i Norden. Förstudiet skal ske i samarbeta med företagsorganisationerna. En regional webbportal av detta slag existerar redan i Öresundsregionen, men denna service kan gärna erbjudas små- och mellanstora företag i hela Norden. Förstudien finansieras genom posterna för Gränsehindersamarbetet.

\section{5-1050-2 Tjänstemannautbyte}

\begin{tabular}{|l|c|c|c|c|c|} 
Valuta & Budget 14 & Budget 13 & Budget 12 & Disp./bud. 12 & Bud.disp. af \\
\hline DKK & 1.321 .000 & 1.554 .000 & 1.527 .000 & $96 \%$ & $\begin{array}{l}\text { Kontakt- } \\
\text { gruppen }\end{array}$
\end{tabular}

Formål

Nordiskt tjänstemannautbyte etablerades 1989 med syfte att

- stärka möjligheterna för statsanställda i Norden att lära känna andra förvaltningar och bli inspirerade av nor- 
diska kollegors arbetsmetoder och praktiker,

- berika den mottagande arbetsplatsen med erfarenheter från sitt hemland,

- främja arbetet på sin hemarbetsplats,

- främja den personliga utvecklingen för den enskilda stipendiaten.

Beviljningen fördelas mellan länderna av en grupp bestående av kontaktpersoner från vart land och självstyrande område. Stipendierna fördelas, utbetalas och rapporteras nationellt.

Budgetposten reduceres med 200 TDKK til at finansiere Hallo Nordens kontaktpunkt på Færeøerne.

Prioriteringer

i 2014

Sekretariatsfunktion
- Kunskapsutveckling

- Nätverksuppbyggnad

- Marknadsföring av ordning

Nordiska ministerrådet upprättar kontrakt med kontaktpersoner i vart land. Länderna ansvarar själva för administrations- och resekostnader i samband med gemensamma möten.

5-0500-2 Pulje till Nordiska ministerrådets stöd till Island

\begin{tabular}{|l|c|c|c|c|c|} 
Valuta & Budget 14 & Budget 13 & Budget 12 & Disp./bud. 12 & Bud.disp. af \\
\hline DKK & 0 & 0 & 1.527 .000 & $93 \%$ & $\begin{array}{c}\text { NSK/MR- } \\
\text { SAM }\end{array}$
\end{tabular}

Formål

Budgetposten er nedlagt. 
5-2055-1 Gränshinderforum

\begin{tabular}{|l|c|c|c|c|c|} 
Valuta & Budget 14 & Budget 13 & Budget 12 & Disp./bud. 12 & Bud.disp. af \\
\hline DKK & 0 & 1.370 .000 & 1.446 .000 & $83 \%$ & $\begin{array}{c}\text { GF efter } \\
\text { rambeslut av } \\
\text { MR-SAM }\end{array}$
\end{tabular}

Formål Budgetposterne for grænsehindringsarbejdet, 5-1035-1 Grænsehindringer og 5-2055-1 Gränshindersforum, er sammenlagt til en ny budgetpost, 5-1036-1, Gränshindringsråd fra og med 2014. 


\section{Globalisering}

\section{Generel Indledning}

Generelt Globalisering identifierades som ett nytt prioriterat område för det nordiska samarbetet i samband med statsministrarnas möte i Punkaharju, Finland 2007. Sedan 2008 har totalt 22 globaliseringsinitiativ startats inom NMR. Globaliseringssatsningen avslutades som helhet vid utgången av år 2012, men vissa av de enskilda initiativen har haft ett motiverat krav för fortsatt finansiering. Dessa initiativ erhåller finansiering från prioriteringsbudgeten.

5-2020-1 Globaliseringsforum

\begin{tabular}{|l|c|c|c|c|c|} 
Valuta & BUDGET 14 & BUDGET 13 & BUDGET 12 & Disp./bud. 12 & Bud.disp. af \\
\hline DKK & 0 & 0 & 8.144 .000 & $81 \%$ & NSK/MR-SAM
\end{tabular}

Budgetposten har utgått

5-2025-2 Nordisk Topforskning

\begin{tabular}{|l|c|c|c|c|c|} 
Valuta & BUDGET 14 & BUDGET 13 & BUDGET 12 & Disp./bud. 12 & Bud.disp. af \\
\hline DKK & 0 & 0 & 2.036 .000 & $80 \%$ & NSK/MR-SAM
\end{tabular}

Budgetposten har utgått

5-2030-2 Innovationsrepresentationer

\begin{tabular}{|l|c|c|c|c|c|} 
Valuta & BUDGET 14 & BUDGET 13 & BUDGET 12 & Disp./bud. 12 & Bud.disp. af \\
\hline DKK & 0 & 0 & 1.527 .000 & $89 \%$ & MR-NER
\end{tabular}

Budgetposten har utgått 
5-2042-1 Energi och transport inkl. uppföljning på gemensamt nordiskt Energi Expo

\begin{tabular}{|l|c|c|c|c|c|} 
Valuta & BUDGET 14 & BUDGET 13 & BUDGET 12 & Disp./bud. 12 & Bud.disp. af \\
\hline DKK & 0 & 0 & 9.162 .000 & $99 \%$ & MR-NER
\end{tabular}

Budgetposten har utgått

5-2055-1 Gränshinderforum

\begin{tabular}{|l|c|c|c|c|c|} 
Valuta & BUDGET 14 & BUDGET 13 & BUDGET 12 & Disp./bud. 12 & Bud.disp. af \\
\hline DKK & 1.222 .000 & 1.370 .000 & 1.446 .000 & $83 \%$ & $\begin{array}{c}\text { GF efter rambeslut } \\
\text { av MR-SAM }\end{array}$
\end{tabular}

Detta projekt fortsätter under Samarbetsministrarnas ram.

5-2060-2 Utvecklingen av det nordiska forsknings- och innovationsområdet (NORIA)

\begin{tabular}{|l|c|c|c|c|c|} 
Valuta & BUDGET 14 & BUDGET 13 & BUDGET 12 & Disp./bud. 12 & Bud.disp. af \\
\hline DKK & 0 & 0 & 2.036 .000 & $80 \%$ & MR-U
\end{tabular}

Projektet avslutades i 2012.

5-2062-1 e-Science

\begin{tabular}{|l|c|c|c|c|c|} 
Valuta & BUDGET 14 & BUDGET 13 & BUDGET 12 & Disp./bud. 12 & Bud.disp. af \\
\hline DKK & 0 & 0 & 8.144 .000 & $100 \%$ & MR-U
\end{tabular}

Projektet är en del av prioriteringsbudgeten. 
5-2065-1 Främjande av högre utbildning i Norden

\begin{tabular}{|l|c|c|c|c|c|} 
Valuta & BUDGET 14 & BUDGET 13 & BUDGET 12 & Disp./bud. 12 & Bud.disp. af \\
\hline DKK & 0 & 0 & 6.108 .000 & $88 \%$ & MR-U
\end{tabular}

Budgetposten har utgått.

5-2070-1 En god uppläring av ungdomar och vuxna

\begin{tabular}{|l|c|c|c|c|c|} 
Valuta & BUDGET 14 & BUDGET 13 & BUDGET 12 & Disp./bud. 12 & Bud.disp. af \\
\hline DKK & 0 & 0 & 2.036 .000 & $90 \%$ & MR-U
\end{tabular}

Projektet avslutades i 2012.

5-2075-2 Belysning av konsekvenserna av klimatförändringarna på naturresurser i Norden

\begin{tabular}{|l|c|c|c|c|c|} 
Valuta & BUDGET 14 & BUDGET 13 & BUDGET 12 & Disp./bud. 12 & Bud.disp. af \\
\hline DKK & 0 & 0 & 4.072 .000 & $100 \%$ & MR-FJLS
\end{tabular}

Projektet är nu del av prioriteringsbudgeten.

5-2076-2 Harmonisering av el-marknaden i Norden

\begin{tabular}{|l|c|c|c|c|c|} 
Valuta & BUDGET 14 & BUDGET 13 & BUDGET 12 & Disp./bud. 12 & Bud.disp. af \\
\hline DKK & 0 & 0 & 1.527 .000 & $98 \%$ & MR-NER
\end{tabular}

Projektet är nu del av prioriteringsbudgeten 
5-2080-2 Kultur och kreativitet

\begin{tabular}{|l|c|c|c|c|c|} 
Valuta & BUDGET 14 & BUDGET 13 & BUDGET 12 & Disp./bud. 12 & Bud.disp. af \\
\hline DKK & 0 & 0 & 6.108 .000 & $80 \%$ & MR-NER
\end{tabular}

Projektet är nu del av prioriteringsbudgeten.

5.2085-2 Hälsa och välfärd

\begin{tabular}{|l|c|c|c|c|c|} 
Valuta & BUDGET 14 & BUDGET 13 & BUDGET 12 & Disp./bud. 12 & Bud.disp. af \\
\hline DKK & 0 & 0 & 13.234 .000 & $94 \%$ & MR-SAM
\end{tabular}

Budgetposten har utgått.

5-2090-1 Klimatvänligt byggeri

\begin{tabular}{|l|c|c|c|c|c|} 
Valuta & BUDGET 14 & BUDGET 13 & BUDGET 12 & Disp./bud. 12 & Bud.disp. af \\
\hline DKK & 0 & 0 & 8.144 .000 & $98 \%$ & MR-NER
\end{tabular}

Projektet är nu del av prioriteringsbudgeten. 


\section{Nordisk Ministerråds budget for virksomhedsåret 2014}

\section{SAMMENSTILLING AF BUDGET 2014 OG 2013 (løbende priser, TDKK)}

\begin{tabular}{|c|c|c|c|c|c|c|}
\hline & \multirow{2}{*}{$\begin{array}{c}\text { Budget } \\
2014\end{array}$} & \multirow[t]{2}{*}{ Andel } & \multirow{2}{*}{$\begin{array}{c}\text { Budget } \\
2013\end{array}$} & \multirow[t]{2}{*}{ Andel } & \multicolumn{2}{|c|}{ Difference } \\
\hline & & & & & $+/-$ & $\%$ \\
\hline Prioriteringsbudgettet & 74.768 & $7,8 \%$ & 81.441 & $8,3 \%$ & -6.673 & $-8,2 \%$ \\
\hline Formandskapspuljen & 30.480 & $3,2 \%$ & 20.360 & $2,1 \%$ & 10.120 & $49,7 \%$ \\
\hline Prioriteringspuljen & 44.288 & $4,6 \%$ & 61.081 & $6,4 \%$ & -16.793 & $-27,5 \%$ \\
\hline $\begin{array}{l}\text { MR-Kultur, MR-FJLS, MR- } \\
\text { Ligestilling }\end{array}$ & 217.891 & $22,8 \%$ & 224.051 & $22,7 \%$ & -6.160 & $-2,7 \%$ \\
\hline Kultur & 167.879 & $17,6 \%$ & 173.335 & $17,6 \%$ & -5.456 & $-3,1 \%$ \\
\hline $\begin{array}{l}\text { Fiskeri, Jord- och skovbrug og } \\
\text { levnedsmidler }\end{array}$ & 41.093 & $4,3 \%$ & 41.598 & $4,4 \%$ & -505 & $-1,2 \%$ \\
\hline Ligestilling & 8.919 & $0,9 \%$ & 9.118 & $0,9 \%$ & -199 & $-2,2 \%$ \\
\hline $\begin{array}{l}\text { MR-Uddannelse og forskning, } \\
\text { MR-S }\end{array}$ & 278.677 & $29,2 \%$ & 283.930 & $28,8 \%$ & -5.253 & $-1,9 \%$ \\
\hline Uddannelse og forskning & 238.384 & $25,0 \%$ & 243.071 & $24,6 \%$ & -4.687 & $-1,9 \%$ \\
\hline Socialpolitik & 40.293 & $4,2 \%$ & 40.859 & $4,1 \%$ & -566 & $-1,4 \%$ \\
\hline $\begin{array}{l}\text { MR-NER, MR-Miljø, MR-A, MR- } \\
\text { Finans }\end{array}$ & 185.409 & $19,4 \%$ & 188.930 & $19,1 \%$ & -3.521 & $-1,9 \%$ \\
\hline Näring, energi og regional & 125.500 & $13,1 \%$ & 127.694 & $12,9 \%$ & -2.194 & $-1,7 \%$ \\
\hline Miljø & 44.392 & $4,6 \%$ & 45.389 & $4,6 \%$ & -997 & $-2,2 \%$ \\
\hline $\begin{array}{l}\text { Arbejds- } \\
\text { liv }\end{array}$ & 13.698 & $1,4 \%$ & 13.992 & $1,4 \%$ & -294 & $-2,1 \%$ \\
\hline Finanspolitik & 1.819 & $0,2 \%$ & 1.855 & $0,2 \%$ & -36 & $-1,9 \%$ \\
\hline MR-Lag & 1.390 & $0,1 \%$ & 1.418 & $0,1 \%$ & -28 & $-2,0 \%$ \\
\hline Lag & 1.390 & $0,1 \%$ & 1.418 & $0,1 \%$ & -28 & $-2,0 \%$ \\
\hline Samarbejdsministrene & 197.080 & $20,6 \%$ & 206.956 & $21,0 \%$ & -9.876 & $-4,8 \%$ \\
\hline Internationalt samarbejde & 89.718 & $9,4 \%$ & 95.592 & $10,0 \%$ & -5.874 & $-6,1 \%$ \\
\hline Ministerrådets sekretariat (NMRS) & 78.204 & $8,2 \%$ & 80.804 & $8,2 \%$ & -2.600 & $-3,2 \%$ \\
\hline $\begin{array}{l}\text { Nordisk Ministerråds fællesaktivite- } \\
\text { ter }\end{array}$ & 29.158 & $3,1 \%$ & 30.560 & $3,1 \%$ & -1.402 & $-4,6 \%$ \\
\hline
\end{tabular}

\begin{tabular}{lllllll}
\hline TOTALT & 955.215 & $100 \%$ & 986.726 & $100 \%$ & -31.511 & $-3,2 \%$ \\
\hline
\end{tabular}




\section{Forhandlinger med Nordisk Råd og det opnåede kompromisforslag ${ }^{2}$}

I efteråret 2013 var der de årlige politiske forhandlinger mellem Nordisk Råd og Nordisk Ministerråd om ministerrådets budgetforslag der resulterede i enighed om følgende, vedtagne ændringer på budgetposter:

- at udrede, om der er effektiviserings- og rationaliseringsgevinster ved at sammenlægge Nordisk Kulturfond og Kulturkontakt Nord, herunder effekterne og fordele og ulemper for det kulturpolitiske arbejde

- at undersøge, om der findes mulige effektiviserings- og rationaliseringsgevinster ved at sammenlægge driftsfunktioner i de tre separate organisationer, der udgør Nordisk Center i Oslo. Styring af institutionerne udredes i generalsekretærens moderniserings-arbejde

- at Nordisk Journalistcenter tilføres 1.000.000 DKK til at fremme journalistiske opgaver med klare og tydelige nordiske formål. Ordningerne skal finansieres fra post 1-2208-1 Strategiska satsningar

- at det af uforbrugte midler i Formandskapspuljen øremærkes i alt 300000 DKK til at fuldføre initiativet Fremst. 41/2012 om selvstyre i Norden i løbet af 2014

- at der er behov for at fremme det internationale samarbejde om tiltag for at modvirke voksende antibakteriel resistens (One Health). Derfor foreslås det, at en fælles nordisk indsats på dette område prioriteres højt, når det kommende nordiske samarbejde omkring folkehelse skal udformes og besluttes i starten af 2014 som følge af afviklingen af Nordic School of Public Health (NHV)

- at holdbare forbrukerpolitiske aspekter tydeliggjøres i det nye arbeidsprogrammet for miljøsektorens arbeidsgruppe - Holbar konsumtion och produksjon - HKP

\footnotetext{
${ }^{2}$ Kompromiserne er indarbejdede i de pågældende budgetposter.
} 
- at det innenfor budsjettrammen for Nordjobb avsettes midler for å markedsføre «Jobbresan» til kommuner i Norden

- at Nordisk Sommeruniversitet (NSU) bliver underlagt NordForsk under forudsætning af, at NSU's aktivitetsniveau fortsætter. NordForsk får i 2014 i opgave at finansiere NSU's virksomhed i 2014 på et tilsvarende niveau som for 2013

- at det avsätts 0,5 miljoner DKK till en förstudie, för att närmare dokumentera behovet av nordiskt sammanhållen information på webben till små- och mellanstora företag som önskar rekrytera personal, etablera sig eller handla över gränserna i Norden. Förstudiet skal ske i samarbeta med företagsorganisationerna. En regional webbportal av detta slag existerar redan i Öresundsregionen, men denna service kan gärna erbjudas små- och mellanstora företag $i$ hela Norden. Förstudien finansieras genom posterna för Gränsehindersamarbete 5-2055-1

- at det innenfor budsjettpost 7-8113-2 (Grønne tekniske normer og standarder - Norden som standardmaker) også inkluderes en vurdering av en harmonisering i Nordisk byggningssektor

- at transport skal inngå i det nye energipolitiske handlingsprogrammet $(2014$ - 2017). Forskning og innovasjon på transportområdet skal også vurderes $\mathrm{i}$ forbindelse med utarbeidingen av nytt energiforskningsprogram (2015 - 2018) for Nordisk energiforskning

- at der innen for budsjettposten "miljøsektorens arbeidsgrupper" (33311-2) øresmerkes midler til å fremme implementeringen af HELCOMs aksjonsplan (BSPA)

- at der er behov for et nordisk studie for at se på patienternes frie bevægelighed i Norden når det nye EU-direktiv (Directive on Cross Border Health Care) er implementeret i landene og de første erfaringer er indhøstet. Spørgsmålet vil indgå i NMR's store 2013 - 2015 program, Holdbar Nordisk Velfærd, herunder vurderes i den gennemgang av samarbejdet på sundhedsområdet som nu gennemføres 


\section{Budgettets indtægter og landenes indbetalinger}

Nordisk Ministerråds budget finansieres i første række af direkte bidrag fra landene. Som udgangspunkt indbetaler landene et beløb svarende til aktivitetsrammen fratrukket afgift på løn, nettorenteindtægter og øvrige indtægter, som det er vist i nedenstående tabel. Landenes indbetalinger sker i henhold til en særskilt fordelingsnøgle, som er beregnet på basis af det respektive lands andel af den samlede bruttonationalindtægt i faktorpriser i Norden for de to seneste kendte år, som i budgettet for 2014 er 2010 og 2011.

\begin{tabular}{|l|rr|rr|rr|}
\hline INDT/EGTER & Budget & $\begin{array}{c}\text { Ford. - } \\
\text { nøgle }\end{array}$ & Budget & $\begin{array}{c}\text { Ford. - } \\
\text { nøgle }\end{array}$ & Budget & $\begin{array}{c}\text { Ford. - } \\
\text { nøgle }\end{array}$ \\
\cline { 2 - 3 } (løbende priser) & $\mathbf{2 0 1 2}$ & $\mathbf{2 0 1 2}$ & $\mathbf{2 0 1 3}$ & $\mathbf{2 0 1 3}$ & $\mathbf{2 0 1 4}$ & $\mathbf{2 0 1 4}$ \\
\hline Afgift på løn & 10.000 & & 11.000 & & 12.000 & \\
Renteindtægter & 500 & & 1.000 & & 800 & \\
Øvrige indtægter & 200 & & 200 & & 300 & \\
\hline Landenes bidrag & 950.772 & & 974.526 & & 942.115 & \\
- Danmark & 210.881 & $22,2 \%$ & 217.319 & $22,3 \%$ & 197.844 & $21,0 \%$ \\
- Finland & 169.142 & $17,8 \%$ & 169.568 & $17,4 \%$ & 153.565 & $16,3 \%$ \\
- Island & 7.226 & $0,8 \%$ & 6.822 & $0,7 \%$ & 6.595 & $0,7 \%$ \\
- Norge & 277.340 & $29,2 \%$ & 285.536 & $29,3 \%$ & 288.287 & $30,6 \%$ \\
- Sverige & 286.182 & $30,1 \%$ & 295.281 & $30,3 \%$ & 295.824 & $31,4 \%$ \\
\hline Sum : & 961.472 & $100 \%$ & 986.726 & $100 \%$ & 955.215 & $100 \%$ \\
\hline
\end{tabular}

\section{Betalingsordningen for højere uddannelser}

Det er besluttet i Overenskomsten om adgang til videregå ende uddannelse, at konsekvenserne af betalingsordningen for de nordiske lande skal reguleres over Ministerrådets budget, og påvirker derved landenes bidrag til det nordiske budget. Betalingsordningen gælder Danmark, Finland, Norge og Sverige. Island, Grønland, Færøerne og Åland står udenfor betalingsordningen. Der tages hensyn til landenes gensidige betalinger i landenes bidrag og aftalen påvirker alene den interne fordeling af bidragene mellem landene (Danmark, Finland, Norge og Sverige). Det er i 2012 besluttet at forlænge overenskomsten til udgangen af 2015.

Af overenskomsten fremgår det, at der skal ske betaling for $75 \%$ af det antal studerende, som modtager studiestøtte fra det land hvor den studerende er bosat efter gældende regler i det land, og som er indskrevet på en 
højere uddannelse $\mathrm{i}$ et andet land, som falder ind under Artikel $1 \mathrm{i}$ overenskomsten.

Forskningsuddannelser samt studerende på uspecificeret højere uddannelse medregnes ikke i beregningsgrundlaget. Den årlige erstatning pr. studerende har hidtil været 22.000 DKK, men er i 2013, 26.000 DKK pr. studerende og i 2014, 30.000 DKK. Derefter skal de 30.000 DKK indeksreguleres.

Ministerrådet modtager statistik fra de nordiske studiestøttemyndigheder, som ligger til grund for beregningen af antal studerende mellem de nordiske lande, der indgår i ordningen.

Betalingsordning, højere uddannelse TDKK

\begin{tabular}{lrrr}
\hline & Budget & Budget & Budget \\
& $\mathbf{2 0 1 2}$ & $\mathbf{2 0 1 3}$ & $\mathbf{2 0 1 4}$ \\
\hline Danmark & -62.205 & -76.830 & -89.078 \\
Finland & 12.689 & 17.335 & 19.777 \\
Island & 0 & 0 & 0 \\
Norge & 38.000 & 46.917 & 58.343 \\
Sverige & 11.517 & 12.578 & 10.958 \\
\hline Sum: & 0 & 0 & 0 \\
\hline
\end{tabular}

\section{Indbetalinger fra landene}

Landenes indbetalinger til Nordisk Ministerråd er følgende efter korrektion for betalingsordningen for højere uddannelse:

Indbetalinger efter betalingsordning og reduktion i grundkapital, løbende priser TDKK

\begin{tabular}{lrrr}
\hline & Budget 2012 & Budget 2013 & Budget 2014 \\
\hline Danmark & 148.676 & 140.489 & 108.766 \\
Finland & 181.831 & 186.903 & 173.342 \\
Island & 7.226 & 6.822 & 6.595 \\
Norge & 315.340 & 332.453 & 346.630 \\
Sverige & 297.699 & 307.859 & 306.782 \\
\hline Sum: & 950.772 & 974.526 & 942.115 \\
\hline
\end{tabular}




\section{Landenes prognosticerede indbetalinger i national valuta}

Nedenfor vises landenes indbetalinger til Nordisk Ministerråd i tusinder af det enkelte lands valuta, med udgangspunkt i de af samarbejdsministrene godkendte budgetvalutakurser, jfr. side 11. Beløbene inkluderer betalingsordningen.

\begin{tabular}{lrl}
\hline Budget 2014 - Landenes prognosticerede bidrag i national valuta \\
\hline Danmark & 108.766 & DKK \\
Finland & 23.236 & EUR \\
Island & 143.365 & ISK \\
Norge & 353.704 & NOK \\
Sverige & 352.623 & SEK \\
\hline
\end{tabular}

\section{Økonomiske og politiske frihedsgrader i Nordisk Ministerråds budget}

I forbindelse med budgetmoderniseringen i februar 2007 var et af forslagene at erstatte den tidligere opgørelse over Ministerrådets planlægningsramme med en prognosticeret opgørelse over de økonomiske frihedsgrader i budgettet i de kommende år.

Oversigten er et forsøg på at lave en opgørelse over det økonomiske, juridiske og politiske råderum, der reelt er i det nordiske budget, dvs. der forsøges at give et billede af størrelsen af de politiske omkostninger ved at frigøre midler på de forskellige budgetposter i budgettet. Derudover skal opgørelsen forsøge at give et billede af de økonomiske omkostninger ved at frigøre midler - det kunne f. eks. være tab af tidligere opbyggede nordiske værdier. Det er væsentligt at notere, at der ikke er tale om en kvalitetsvurdering af de nordiske aktiviteter - opgørelsen er alene et forsøg på at vise udgiftsstrukturen i det nordiske budget ud fra et perspektiv om frihedsgraderne i budgettet.

Det skal understreges, at prognosen er lavet på baggrund af den totale ramme i 2014 og samme rammefordeling på ministerråd som i 2014 og ikke mindst på grundlag af det institutionelle set-up og organisationsstrukturen i de enkelte sektorer. I forbindelse med budgetbehandlingen i sektorerne i foråret 2013 er opgørelserne for de enkelte ministerråd forelagt det politiske niveau. 
I opgørelsen inddeles budgetsektorernes midler i tre kategorier. Der begyndes med de midler, som er mindst bundet. Der tages udgangspunkt i rammerne og budgetfordelingen på budgetposterne i budgetforslag 2014.

De tre kategorier er:

Kategori 1: Midler der benyttes til korte, enkeltstående og tidsbegrænsede projekter. Det er midler, der tildeles på ad hoc basis. I denne kategori ligger udover projektmidlerne også de midler, der i de nordiske institutioner har projektlignende karakter.

Kategori 2: Kontraktbundne midler er midler, hvor Nordisk Ministerråd har givet signal om, eller hvor der i forbindelse med uddeling af midler klart fra Ministerrådet ligger en hensigtserklæring om finansiering over flere år. I denne kategori medtages midler, hvor Nordisk Ministerråd er den eneste finansieringskilde. I denne kategori ligger f.eks. støtteordninger og større programmer og eventuelt samarbejdsorganer og arbejdsgrupper.

Kategori 3: Midler i kategori 3 er midler, som binder Nordisk Ministerråd juridisk. Det drejer sig om leasing- og huslejeaftaler samt institutionernes personale i et vist tidsrum (typisk 6 måneder). Denne kategori er kun aktuel for de nordiske institutioner.

Fordeling på de tre kategorier ser således ud:

\begin{tabular}{|lccc|}
\hline $\begin{array}{l}\text { Opgørelse over frihedsgrader i Nordisk Ministerråds budget 2014 } \\
\text { (2013 priser) }\end{array}$ & Budget overslag 2015 \\
\hline Graden af frihed & $\mathbf{1}$ & $\mathbf{3}$ \\
\hline MR-Kultur, MR-FJLS, MR-Ligestilling & $\mathbf{1 2 . 6 7 3}$ & $\mathbf{1 6 9 . 2 4 9}$ & $\mathbf{3 1 . 8 7 2}$ \\
\hline & & & 11.953 \\
Kultur & 8.230 & 144.949 & 19.919 \\
Fiskeri, Jord- och skovbrug og levnedsmidler & 964 & 19.000 & 0 \\
Ligestilling & 3.479 & 5.300 & $\mathbf{2 2 . 7 6 2}$ \\
& & & 12.544 \\
& & & 10.218 \\
\hline MR-Uddannelse og forskning, MR-S & $\mathbf{4 2 . 7 4 9}$ & $\mathbf{2 0 7 . 4 4 6}$ & \\
\hline Uddannelse og forskning & 28.500 & 192.826 & $\mathbf{2 8 . 3 2 0}$ \\
Socialpolitik & 14.249 & 14.620 & 27.470
\end{tabular}




\begin{tabular}{|c|c|c|c|}
\hline Miljø & 6.149 & 37.544 & 0 \\
\hline Arbejdsliv & 5.088 & 7.519 & 850 \\
\hline Finanspolitik & 1.790 & 0 & 0 \\
\hline MR-Lag & 1.368 & $\mathbf{0}$ & $\mathbf{0}$ \\
\hline Lag & 1.368 & 0 & 0 \\
\hline Nabopolitik & 66.749 & 9.174 & 12.403 \\
\hline Samarbejdsministrene & 44.459 & 22.331 & 38.956 \\
\hline Ministerrådets sekretariat (NMRS) & 38.092 & 0 & 38.956 \\
\hline Nordisk Ministerråds fællesaktiviteter & 6.367 & 22.331 & 0 \\
\hline TOTALT & 215.604 & 513.882 & 134.313 \\
\hline
\end{tabular}

Som det ses af tabellen er der i 2014 lidt over 134 MDKK af Ministerrådets budget, der er juridisk kontraktbundne. Af de resterende midler er knap 514 MDKK midler, der i større eller mindre grad er bundet op i kontrakter eller hvor der er givet et signal om at finansieringen også fortsætter ud over budgetåret. Og ca. 216 MDKK kan betegnes som frie midler der bruges på år-til-år basis til aktiviteter af engangskarakter. I disse tal er prioriteringsbudgettet ikke inkluderet. 


\section{Historisk udvikling i Nordisk Ministerråds budget og likviditet}

\section{Udviklingen i udisponerede midler 2010 - 2012}

Udisponerede midler er defineret som midler, hvor der ikke er foretaget en beslutning om anvendelse til et bestemt formål. Udisponerede midler kan alene forekomme under budgetposter med projektmidler og programlignende aktiviteter, idet ministerrådet på institutioner og organisationsbidrag udbetaler alle midler til eksterne parter, som har dispositionsretten over midlerne, og derfor er disse midler i Ministerrådets budget altid pr. definition $100 \%$ disponeret. Projektmidler og programlignende aktiviteter udgjorde totalt ca. $56 \%$ af ministerrådets budget i 2012 .

I forbindelse med budgetmoderniseringen og vedtagelse af Generalsekretærens forslagskatalog i februar 2007 besluttede MR-SAM at indføre en $20 \%$-regel, kombineret med et minimumsbeløb på 200.000 DKK, som betyder, at højst $20 \%$ af årets budget på en budgetpost kan videreføres til næste år; dog kan man altid videreføre 200.000 DKK. ${ }^{3}$

Det forventes, at reglen dels fremskynder projektinitieringen og øger afløbstempoet for Ministerrådets projekter, og dels giver ekstra muligheder for politiske prioriteringer.

Dog er der naturligvis også risiko for at skærpede krav til overførselsadgang kan medvirke til, at der i højere grad bliver disponeret midler til projekter, der ikke umiddelbart er prioriteret højt politisk.

Samarbejdsministrene besluttede i maj måned 2009, at fra og med virksomhedsår 2009 skal midler, som falder for $20 \%$, tilbageføres til landene. Beslutningen er taget på baggrund af, at budgetrammen i 2008 blev udvidet med et engangsløft på 35 MDKK til finansiering af globaliseringsinitaitiverne.

På budgetpostniveau under hvert ministerråd viser rubrikken "Disp./Bud 12", hvor meget der er disponeret i budgetåret 2012 ud af midler til rådighed. I bilag 2 vises ligeledes en samlet oversigt over regnskabstal på alle budgetposter, hvor også dispositionsprocenterne er vist.

\footnotetext{
${ }^{3}$ Minimumsgrænsen er indført af hensyn til de små projektbudgetposter, som en procentordning alene vil ramme uforholdsmæssigt hårdt.
} 
Nedenfor er grafisk vist de udisponerede midler i 2010 - 2012 samt en oversigt over fordelingen af de udisponerede midler på ministerråd i TDKK og i procent af sektorens samlede ramme.

Som det ses af grafen og den efterfølgende tabel, steg de udisponerede midler fra 2011 til 2012 med 11,5 MDKK - som primært skyldes en tilbageførsel af ca. 12 MDKK på Nordplus programmet. Uden den tilbageføring ville de udisponerede midler udgøre $2,7 \%$ af det totale budget.

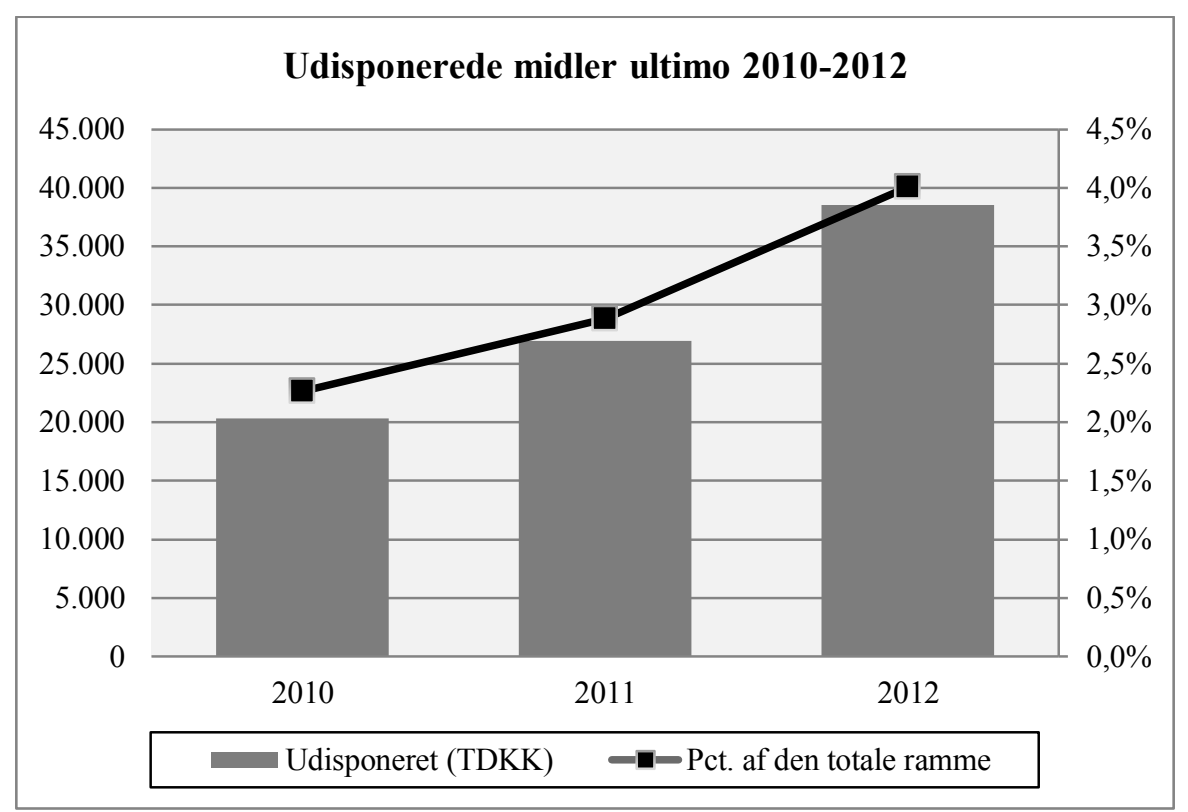


Historisk udvikling i Nordisk Ministerråds budget og likviditet

Udis ponere de midler ultimo 2010-2012

\begin{tabular}{|c|c|c|c|c|c|c|c|}
\hline Sektor (TDKK) & 2010 & $\begin{array}{c}\% \text { af sekt. } \\
\text { størrelse }\end{array}$ & 2011 & $\begin{array}{l}\% \text { af sekt. } \\
\text { storrelse }\end{array}$ & 2012 & $\begin{array}{c}\% \text { af sekt. } \\
\text { storrelse }\end{array}$ & $\begin{array}{l}\text { Beskåret jf. } \\
20 \% \text { regl. }\end{array}$ \\
\hline Globalis eringsinitiativer & 3.975 & $6 \%$ & 6.794 & $9 \%$ & 6.374 & $9 \%$ & \\
\hline Kulturpolitik & 1.494 & $1 \%$ & 1.484 & $1 \%$ & 1.548 & $1 \%$ & \\
\hline Uddannelse og forskning & 1.494 & $1 \%$ & 1.791 & $1 \%$ & 14.026 & $6 \%$ & 691 \\
\hline Internationalt samarbejde & 3.986 & $4 \%$ & 7.272 & $8 \%$ & 6.819 & $7 \%$ & \\
\hline Miljø & 1.112 & $3 \%$ & 1.238 & $3 \%$ & 672 & $2 \%$ & \\
\hline Ekonomi og Finanspolitik & 4 & $0 \%$ & 14 & $1 \%$ & 165 & $9 \%$ & \\
\hline MR-FJLS & 634 & $2 \%$ & 1.392 & $4 \%$ & 623 & $2 \%$ & \\
\hline Arbejds livspolitik & 1.131 & $9 \%$ & 816 & $6 \%$ & 1.028 & $8 \%$ & \\
\hline Social- og Helsepolitik & 223 & $1 \%$ & 615 & $2 \%$ & 361 & $1 \%$ & \\
\hline Ligestilling & 83 & $1 \%$ & 496 & $6 \%$ & 465 & $5 \%$ & \\
\hline MR-NER & 2.798 & $3 \%$ & 2.308 & $2 \%$ & 1.450 & $1 \%$ & \\
\hline Lagstiftning & 271 & $20 \%$ & 167 & $12 \%$ & 223 & $16 \%$ & \\
\hline Øvrig virksomhet & 3.150 & $3 \%$ & 2.573 & $2 \%$ & 4.754 & $4 \%$ & 4.371 \\
\hline SUM & 20.355 & $2,3 \%$ & 26.960 & $2,9 \%$ & 38.508 & $4,0 \%$ & 5.062 \\
\hline
\end{tabular}

\section{Budgettets udvikling i perioden 2003 - 2014}

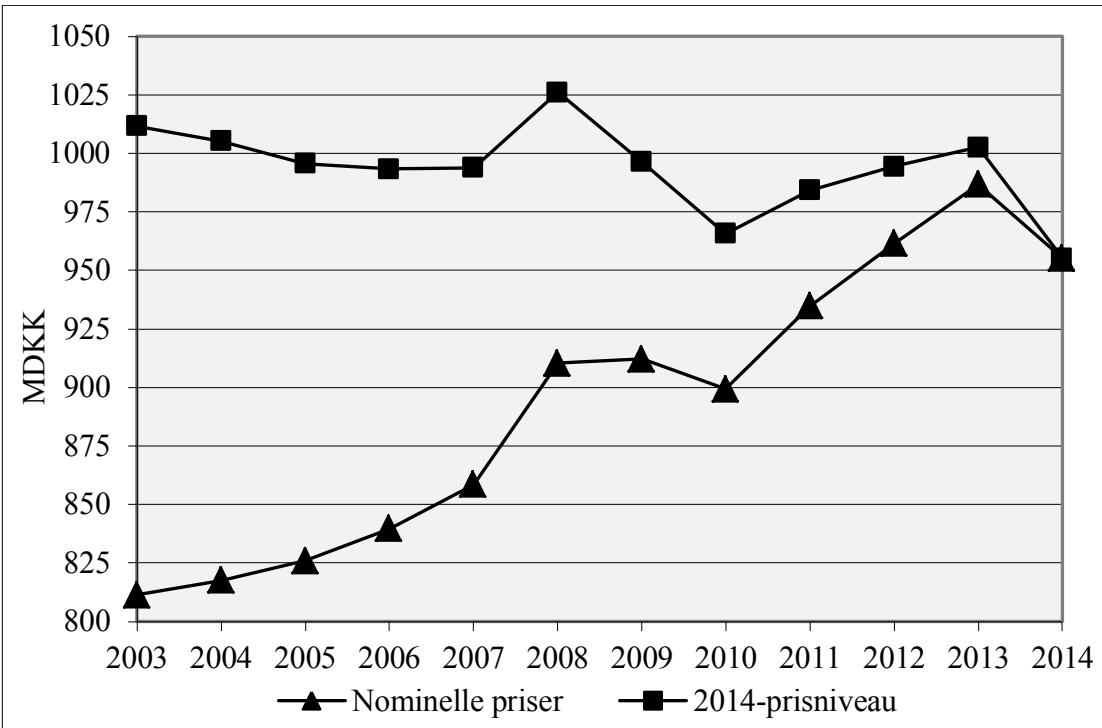

MR-SAM har for 2014 vedtaget en ramme der indeholder $5 \%$ nedskæring (-49 MDKK) i budgetrammen i forhold til 2013. Niveauskiftet i 2008 skal ses på baggrund af beslutningen i forbindelse med budget 2008 om at finansiere en del af globaliseringssatsninger på $60 \mathrm{MDKK}$ i 2008, som 
statsministrene lancerede i Punkaharju i Finland i juni 2007, med en forøgelse af aktivitetsrammen på 35 MDKK.

Når budgettet i faste priser i 2010 falder i forhold til 2009 og fortsat i 2011 ligger under niveauet for 2009 skyldes det de udsving der har været i valutakurserne. I denne situation skyldes det konkret det store fald i norske og svenske kroners værdi fra sidste halvdel af 2008 til midten af 2009 i forhold til danske kroner. Stigningen fra 2011 til 2012 og forsat til 2013 skyldes på samme måde stigningen i norske og svenske kroner i forhold til danske kroner.

\section{Likviditetens udvikling}

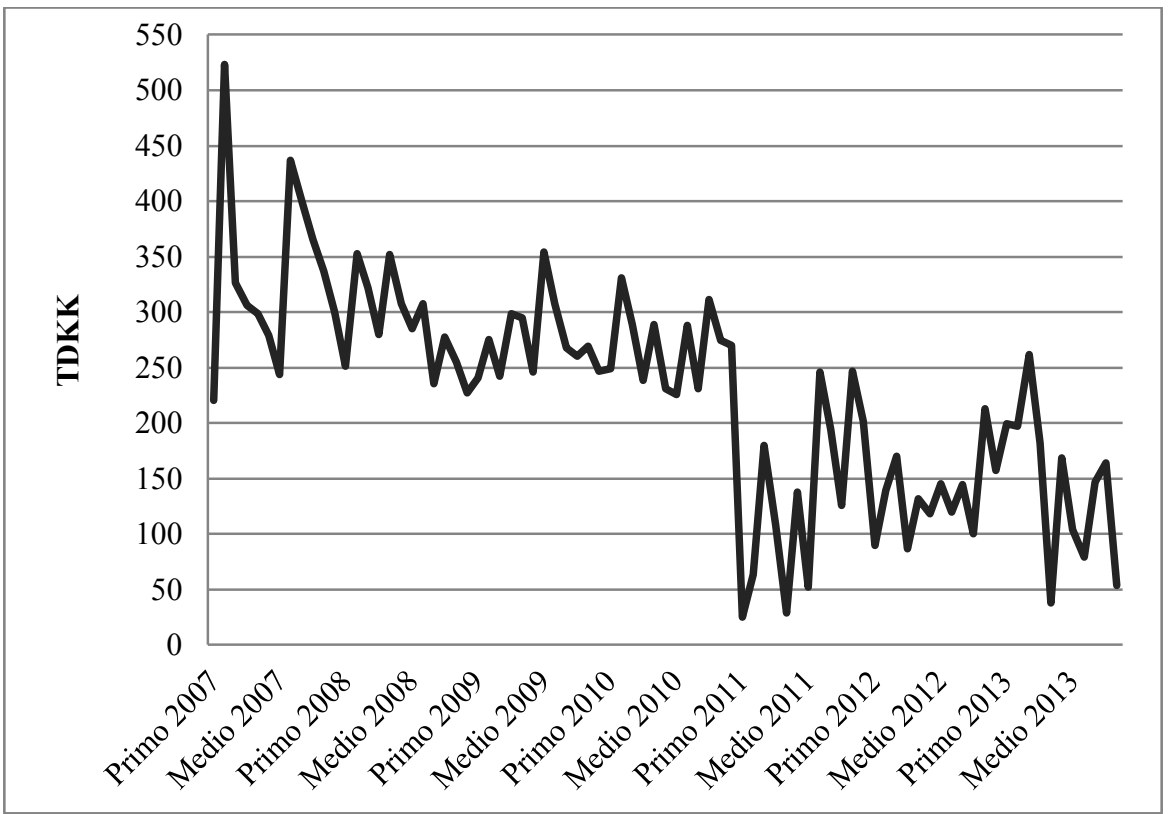

Som det ses af grafen udviser Ministerrådets likviditet et fast mønster. Mønsteret er generet af, at udbetalinger forløber nogenlunde jævnt over året og at landene indbetaler på faste tidspunkter i løbet af året.

Fra og med budgetåret 2008 er landene begyndt at indbetale 4 gange årligt mod tidligere 2 gange, som betyder et ændret mønster i Ministerrådets likviditetsbeholdning. 
Det har i flere gange over den viste periode været landenes synspunkter, at ministerrådets likviditet har været for høj. Derfor har der i flere omgange været forsøg på at nedbringe den, senest da MR-SAM i november 2010 besluttede at forskyde landenes indbetalinger med to måneder. Effekten herefter er, som ses af figuren, at ministerrådets likviditet er reduceret betydeligt og på visse tidspunkter af året er tæt på 0 .

\section{Budgettets fordeling på budgetpostkategorier}

Nedenfor vises budgettet fordelt på budgetkategorier. Foruden de fire kategorier, projektmidler, programlignende aktiviteter, institutioner og organisationsbidrag, er prioriteringsbudgettet skilt ud som selvstændig kategori. Derudover er bevillingerne til ministerrådssekretariatet og kontoren i Nordvestrusland samt i Estland, Letland, og Litauen defineret som institutioner, men vist separat i diagrammerne nedenfor.

De ordninger, som administreres af de nordiske institutioner NordForsk og Nordisk Innovation indgår i institutionsandelen. Nordisk projekteksportfond (Nopef) er nedlagt som selvstendig institution fra og med 2014 og omdannet til trust fund, Nopef TF, under NEFCO.

Nedenstående tabel viser udvikling i budgettets fordeling på udgiftskategorier.

\begin{tabular}{lcccc} 
I TDKK & \multicolumn{2}{c}{ Budget 2014 } & \multicolumn{2}{c}{ Budget 2013 } \\
\hline Prioriteringsbudget & 74.768 & $7,8 \%$ & 81.441 & $8,3 \%$ \\
Projektmidler & 106.275 & $11,1 \%$ & 116.899 & $11,8 \%$ \\
Programlignende aktiviteter & 347.112 & $36,3 \%$ & 338.210 & $34,3 \%$ \\
Institutioner & 309.327 & $32,4 \%$ & 327.805 & $33,2 \%$ \\
Organisationsbidrag & 18.452 & $1,9 \%$ & 19.802 & $2,0 \%$ \\
Sekretariatet og kontorerne & 99.281 & $10,4 \%$ & 102.569 & $10,4 \%$ \\
\hline I alt & 955.215 & $100 \%$ & 986.726 & $100 \%$
\end{tabular}




\section{4}

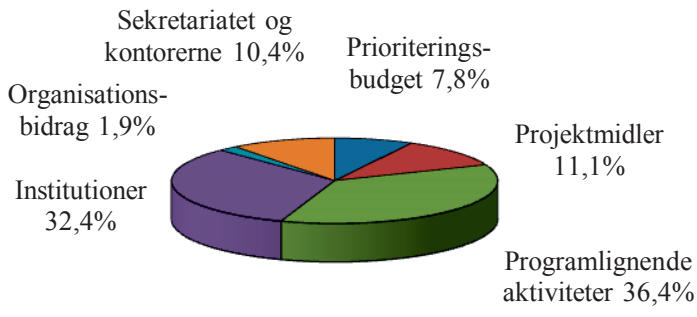

2013

Sekretariatet og kontorerne $10,4 \%$ Prioriterings-

Organisationsbudget $8,3 \%$

bidrag 2,0\%

Institutioner

$33,2 \%$

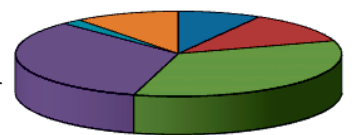

Projektmidler

$11,8 \%$

Programlignende aktiviteter $34,3 \%$ 


\section{Bilag 1 - Budgettet konverteret til EURO}

\begin{tabular}{|c|c|c|c|c|c|}
\hline & MR-Kultur & Budget & Budget & Diffe & rence \\
\hline & & 2014 & 2013 & $+/-$ & $\%$ \\
\hline MR-K & & 22.504 & 23.235 & -731 & $-3,1 \%$ \\
\hline & Generelle kulturinnsatser & 6.222 & 6.521 & -299 & $-4,6 \%$ \\
\hline $1-2203-1$ & Dispositionsmidler Kultur & 138 & 270 & -132 & $-48,9 \%$ \\
\hline $1-2205-2$ & Nordisk kulturfond & 4.628 & 4.728 & -100 & $-2,1 \%$ \\
\hline $1-2206-2$ & Nordisk Råds priser & 473 & 324 & 149 & $45,9 \%$ \\
\hline $1-2208-1$ & Strategiska satsningar & 983 & 1.199 & -216 & $-18,0 \%$ \\
\hline & Barn och unga & 813 & 830 & -17 & $-2,1 \%$ \\
\hline & Projektmedel och generella stödordningar & 813 & 830 & -17 & $-2,1 \%$ \\
\hline $1-2212-2$ & $\begin{array}{l}\text { Nordisk Børne- og Ungdomskomité } \\
\text { (NORDBUK) }\end{array}$ & 813 & 830 & -17 & $-2,1 \%$ \\
\hline & Film och media & 4.988 & 5.293 & -306 & $-5,8 \%$ \\
\hline & Projektmedel och generella stödordningar & 4.566 & 4.890 & -324 & $-6,6 \%$ \\
\hline $1-2221-2$ & Nordisk computerspilprogram & 886 & 909 & -23 & $-2,5 \%$ \\
\hline $1-2222-2$ & Nordisk Film- och TV-fond & 3.680 & 3.622 & 58 & $1,6 \%$ \\
\hline $1-2223-2$ & Nordisk Journalistisk Efteruddannelse & 0 & 359 & -359 & \\
\hline & Institutioner & 421 & 403 & 18 & $4,5 \%$ \\
\hline $1-2228-3$ & NORDICOM & 421 & 403 & 18 & $4,5 \%$ \\
\hline & Konstområdet & 9.985 & 10.102 & -117 & $-1,2 \%$ \\
\hline & Projektmedel och generella stödordningar & 4.386 & 4.317 & 69 & $1,6 \%$ \\
\hline $1-2251-2$ & Kultur- og kunstprogrammet & 2.349 & 2.312 & 37 & $1,6 \%$ \\
\hline $1-2253-2$ & Nordisk oversættelsesstøtte & 405 & 399 & 6 & $1,6 \%$ \\
\hline $1-2254-2$ & $\begin{array}{l}\text { Nordiskt-baltiskt mobilitetsprogram för } \\
\text { Kultur }\end{array}$ & 1.632 & 1.606 & 26 & $1,6 \%$ \\
\hline & Nordiska kulturhus (institutioner) & 5.599 & 5.785 & -186 & $-3,2 \%$ \\
\hline $1-2270-3$ & Nordens hus i Reykjavik & 1.128 & 1.177 & -49 & $-4,2 \%$ \\
\hline $1-2272-3$ & Nordens hus på Färöarna & 1.787 & 1.841 & -54 & $-2,9 \%$ \\
\hline $1-2274-3$ & Nordens institut på Åland & 388 & 404 & -16 & $-3,9 \%$ \\
\hline $1-2277-3$ & Nordens institut på Grönland (NAPA) & 837 & 859 & -22 & $-2,5 \%$ \\
\hline $1-2548-3$ & Kulturkontakt Nord & 1.459 & 1.505 & -46 & $-3,1 \%$ \\
\hline & Andra kultursatsningar & 496 & 488 & 8 & $1,6 \%$ \\
\hline & Projektmedel och generella stödordningar & 496 & 488 & 8 & $1,6 \%$ \\
\hline $1-2234-4$ & Samisk samarbeid & 496 & 488 & 8 & $1,6 \%$ \\
\hline Opdelt pa & kategorier & 22.504 & 23.235 & $100 \%$ & $100 \%$ \\
\hline & Projektmidler & 1.121 & 2.658 & $5,0 \%$ & $11,4 \%$ \\
\hline & Programlignende aktiviteter & 14.867 & 13.901 & $66,1 \%$ & $59,8 \%$ \\
\hline & Institutioner & 6.020 & 6.189 & $26,8 \%$ & $26,6 \%$ \\
\hline & Organisationsbidrag & 496 & 488 & $2,2 \%$ & $2,1 \%$ \\
\hline
\end{tabular}




\begin{tabular}{|c|c|c|c|c|c|}
\hline & MR-FJLS & Budget & Budget & Diffe & ence \\
\hline & & 2014 & 2013 & $+/-$ & $\%$ \\
\hline MR-FJLS & & 5.508 & 5.576 & -68 & $-1,2 \%$ \\
\hline & Projektmidler & 230 & 318 & -88 & $-27,6 \%$ \\
\hline $3-6420-2$ & Ny nordisk mad & 230 & 318 & -88 & $-27,6 \%$ \\
\hline & Fiskeri & 818 & 836 & -18 & $-2,1 \%$ \\
\hline $3-6610-1$ & Projektmedel - Fiskeri & 818 & 836 & -18 & $-2,1 \%$ \\
\hline & Jord-och skovbrug & 3.721 & 3.667 & 54 & $1,5 \%$ \\
\hline & Projektmidler - jordbrug & 157 & 160 & -3 & $-2,1 \%$ \\
\hline $3-6510-1$ & Projektmidler Jordbrug & 49 & 50 & -1 & $-2,2 \%$ \\
\hline $3-6520-2$ & $\begin{array}{l}\text { Nordiskt kontaktorgan för jordbruksforsk- } \\
\text { ning (NKJ) }\end{array}$ & 108 & 110 & -2 & $-2,1 \%$ \\
\hline & Institutioner - jordbrug & 2.790 & 2.715 & 74 & $2,7 \%$ \\
\hline $3-6585-3$ & Nordisk Genressource Center (NordGen) & 2.790 & 2.715 & 74 & $2,7 \%$ \\
\hline & Projektmidler - skovbrug & 775 & 792 & -17 & $-2,1 \%$ \\
\hline $3-6310-1$ & Projektmidler Skovbrug & 40 & 41 & -1 & $-2,0 \%$ \\
\hline $3-6581-2$ & Samnordisk skogsforskning (SNS) & 734 & 751 & -16 & $-2,1 \%$ \\
\hline & Levnedsmidler & 739 & 755 & -16 & $-2,1 \%$ \\
\hline $3-6810-1$ & Projektmedel - Levnedsmidler & 666 & 681 & -15 & $-2,1 \%$ \\
\hline $3-6830-1$ & $\begin{array}{l}\text { Nordisk handlingsplan for bedre helse og } \\
\text { livskvalitet }\end{array}$ & 72 & 74 & -2 & $-2,2 \%$ \\
\hline Opdelt på & kategorier & 5.508 & 5.576 & $49 \%$ & $79 \%$ \\
\hline & Projektmidler & 1.646 & 1.682 & $29,9 \%$ & $30,2 \%$ \\
\hline & Programlignende aktiviteter & 1.073 & 1.179 & $19,5 \%$ & $48,7 \%$ \\
\hline & Institutioner & 2.790 & 2.715 & $50,6 \%$ & $48,7 \%$ \\
\hline
\end{tabular}

MR-JÄM

\begin{tabular}{lrrrr} 
& 2014 & 2013 & $+/-$ & $\%$ \\
\hline MR-Jäm & 1.196 & 1.222 & -27 &
\end{tabular}

\begin{tabular}{crrrr}
\hline Opdelt på kategorier & $\mathbf{1 . 1 9 6}$ & $\mathbf{1 . 2 2 2}$ & $\mathbf{1 0 0 \%}$ & $\mathbf{1 0 0 \%}$ \\
\hline Projektmidler & 855 & 813 & $71,5 \%$ & $66,5 \%$ \\
Programlignende aktiviteter & 340 & 409 & $28,5 \%$ & $33,5 \%$
\end{tabular}


MR-U

\begin{tabular}{|c|c|c|c|c|c|}
\hline & \multirow{2}{*}{2014} & \multirow{2}{*}{2013} & \\
\hline & & & & $+/-$ & $\%$ \\
\hline \multirow[t]{2}{*}{ MR-U } & & 31.955 & 32.583 & -628 & $-1,9 \%$ \\
\hline & $\begin{array}{l}\text { Generelle utdannings- og forskningsinnsat- } \\
\text { ser }\end{array}$ & 394 & 656 & -262 & $-40,0 \%$ \\
\hline \multirow[t]{2}{*}{$2-2505-1$} & Dispositionsmedel-Utbildning och forskning & 394 & 656 & -262 & $-40,0 \%$ \\
\hline & Politikudvikling m.v. & 2.392 & 2.160 & 232 & $10,7 \%$ \\
\hline $2-2560-1$ & $\begin{array}{l}\text { Ad hoc arbejdsrupper på prioriterede områ- } \\
\text { der }\end{array}$ & 348 & 409 & -62 & $-15,0 \%$ \\
\hline $2-2544-1$ & Det nordiske sprogsamarbejde & 926 & 731 & 195 & $26,7 \%$ \\
\hline $2-2553-1$ & $\begin{array}{l}\text { Politikudvikling, Videnssamfund og IT- } \\
\text { infrastruktur }\end{array}$ & 75 & 82 & -7 & $-8,5 \%$ \\
\hline \multirow[t]{2}{*}{$2-3127-2$} & Politikudvikling voksnes læring & 1.043 & 938 & 105 & $11,2 \%$ \\
\hline & Mobilitets og netvarksprogrammer & 10.002 & 10.154 & -152 & $-1,5 \%$ \\
\hline $2-2513-2$ & Nordplus & 10.002 & 9.845 & 158 & $1,6 \%$ \\
\hline $2-2534-4$ & $\begin{array}{l}\text { Bidrag till Nordisk Sommaruniversitet } \\
\text { (NSU) }\end{array}$ & 0 & 162 & -162 & - \\
\hline \multirow[t]{2}{*}{$2-2545-2$} & $\begin{array}{l}\text { Samarbejdsnævnet for Nordenundervisning i } \\
\text { udlandet }\end{array}$ & 0 & 147 & -147 & - \\
\hline & NordForsk & 16.271 & 16.050 & 221 & $1,4 \%$ \\
\hline $2-3100-3$ & NordForsk & 16.271 & 15.913 & 358 & $2,3 \%$ \\
\hline \multirow[t]{2}{*}{$2-3140-2$} & Nordisk komitè for Bioetikk & 0 & 137 & -137 & - \\
\hline & Forskning $i$ øvrigt & 2.895 & 3.562 & -667 & $-18,7 \%$ \\
\hline $2-3180-2$ & $\begin{array}{l}\text { Nordisk Institut for Teoretisk Fysik (NOR- } \\
\text { DITA) }\end{array}$ & 1.189 & 1.463 & -274 & $-18,7 \%$ \\
\hline $2-3181-2$ & Nordiska Institutet for Sjörett (NIfS) & 354 & 436 & -82 & $-18,7 \%$ \\
\hline $2-3182-2$ & Nordisk Institutt for Asiastudier (NIAS) & 562 & 691 & -129 & $-18,7 \%$ \\
\hline $2-3184-2$ & $\begin{array}{l}\text { Nordisk vulkanologisk institut (NORD- } \\
\text { VULK) }\end{array}$ & 574 & 706 & -132 & $-18,7 \%$ \\
\hline $2-3185-2$ & Nordisk Samisk Institutt (NSI) & 217 & 267 & -50 & $-18,7 \%$ \\
\hline
\end{tabular}

\begin{tabular}{crrrr}
\hline Opdelt på kategorier & $\mathbf{3 1 . 9 5 5}$ & $\mathbf{3 2 . 5 8 3}$ & $\mathbf{1 0 0} \%$ & $\mathbf{1 0 0} \%$ \\
\hline Projektmidler & 1.743 & 2.015 & $5,5 \%$ & $6,2 \%$ \\
Programlignende aktiviteter & 13.941 & 14.492 & $43,6 \%$ & $44,5 \%$ \\
Institutioner & 16.271 & 15.913 & $50,9 \%$ & $48,8 \%$ \\
Organisationsbidrag & 0 & 162 & $0,0 \%$ & $0,5 \%$
\end{tabular}

\begin{tabular}{llrrrr} 
& MR-S & $\begin{array}{r}\text { Budget } \\
\mathbf{2 0 1 4}\end{array}$ & $\begin{array}{r}\text { Budget } \\
\mathbf{2 0 1 3}\end{array}$ & $\begin{array}{c}\text { Difference } \\
+/-\end{array}$ & $\mathbf{\%}$ \\
\hline MR-S & & $\mathbf{5 . 4 0 1}$ & $\mathbf{5 . 4 7 7}$ & $\mathbf{- 7 6}$ & $\mathbf{- 1 , 4 \%}$ \\
& & & & & \\
& Projektmedel & 2.567 & 2.627 & -60 & $-2,3 \%$ \\
\hline $4-4310-1$ & Projekmedel - Social- och hälsovårdspolitik & 767 & 772 & -4 & $-0,5 \%$ \\
$4-4320-1$ & $\begin{array}{l}\text { Rådet för nordiskt samarbete om funktions- } \\
\text { hinder }\end{array}$ & 148 & 153 & -5 & $-3,2 \%$ \\
$4-4340-1$ & Nomesko og Nososko & 250 & 257 & -7 & $-2,7 \%$ \\
$4-4382-2$ & $\begin{array}{l}\text { NIOM AS - Nordisk institutt for Odontolo- } \\
\text { giske Materialer }\end{array}$ & 1.402 & 1.445 & -44 & $-3,0 \%$
\end{tabular}




\begin{tabular}{|c|c|c|c|c|c|}
\hline & Institutioner & 2.834 & 2.850 & -16 & $-0,6 \%$ \\
\hline $4-4380-3$ & Nordens Välfärdcenter & 2.834 & 2.850 & -16 & $-0,6 \%$ \\
\hline $4-4381-3$ & $\begin{array}{l}\text { Nordiska högskolan för folkhälsovetenskab } \\
(\mathrm{NHV})^{*}\end{array}$ & 5.363 & 5.134 & 230 & $4,5 \%$ \\
\hline \multicolumn{2}{|c|}{ Opdelt på kategorier } & 5.401 & 5.477 & $100 \%$ & $100 \%$ \\
\hline & Projektmidler & 1.166 & 1.182 & $21,6 \%$ & $21,6 \%$ \\
\hline & Programlignende aktiviteter & 1.402 & 1.445 & $25,9 \%$ & $26,4 \%$ \\
\hline & Institutioner & 2.834 & 2.850 & $52,5 \%$ & $52,0 \%$ \\
\hline
\end{tabular}

* NHV er finansieret direkte af landene, og indgår derfor ikke i de akkumulerede beløb.

\begin{tabular}{|c|c|c|c|c|c|}
\hline & \multirow[t]{2}{*}{ MR-NER } & \multirow{2}{*}{$\begin{array}{c}\text { Budget } \\
2014\end{array}$} & \multirow{2}{*}{$\begin{array}{c}\text { Budget } \\
2013\end{array}$} & \multicolumn{2}{|c|}{ Difference } \\
\hline & & & & $+/-$ & $\%$ \\
\hline \multirow[t]{2}{*}{ MR-NER } & & 16.823 & 17.117 & -294 & $-1,7 \%$ \\
\hline & Näring & 10.865 & 11.043 & -178 & $-1,6 \%$ \\
\hline & Projektmidler - Näring & 262 & 268 & -5 & $-2,0 \%$ \\
\hline \multirow[t]{2}{*}{$4-5140-1$} & Projektmidler Näring & 262 & 268 & -5 & $-2,0 \%$ \\
\hline & Institutioner - Näring & 10.603 & 10.775 & -173 & $-1,6 \%$ \\
\hline \multirow[t]{2}{*}{$4-5180-3$} & Nordisk Innovation & 10.603 & 10.775 & -173 & $-1,6 \%$ \\
\hline & Energi & 1.496 & 1.535 & -39 & $-2,5 \%$ \\
\hline $4-5141-1$ & Projektmidler Energi & 562 & 298 & 264 & $88,8 \%$ \\
\hline \multirow[t]{2}{*}{$4-5142-2$} & Arbejdsgrupper - energi & 0 & 278 & -278 & - \\
\hline & Institutioner - Energi & 934 & 959 & -25 & $-2,6 \%$ \\
\hline \multirow[t]{2}{*}{$4-3220-3$} & Nordisk Energiforskning (NEF) & 934 & 959 & -25 & $-2,6 \%$ \\
\hline & Regional & 4.462 & 4.539 & -77 & $-1,7 \%$ \\
\hline $4-5143-1$ & Projektmidler Regional & 723 & 503 & 220 & $43,7 \%$ \\
\hline $4-5151-4$ & NORA & 890 & 914 & -24 & $-2,7 \%$ \\
\hline \multirow[t]{2}{*}{$4-5160-2$} & Grenseregionalt samarbeid & 1.280 & 1.583 & -303 & $-19,1 \%$ \\
\hline & Institutioner - Regional & 1.568 & 1.539 & 30 & $1,9 \%$ \\
\hline $4-6180-3$ & Nordregio & 1.568 & 1.539 & 30 & $1,9 \%$ \\
\hline \multicolumn{2}{|c|}{ Opdelt på kategorier } & 16.823 & 17.117 & $100 \%$ & $100 \%$ \\
\hline & Projektmidler & 1.547 & 1.068 & $9,2 \%$ & $6,2 \%$ \\
\hline & Programlignende aktiviteter & 1.280 & 1.861 & $7,6 \%$ & $10,9 \%$ \\
\hline & Institutioner & 13.106 & 13.273 & $77,9 \%$ & $77,5 \%$ \\
\hline & Organisationsbidrag & 890 & 914 & $5,3 \%$ & $5,3 \%$ \\
\hline & \multirow[t]{2}{*}{ MR-Miljø } & Budget & Budget & \multicolumn{2}{|c|}{ Difference } \\
\hline & & 2014 & 2013 & $+/-$ & $\%$ \\
\hline \multicolumn{2}{|l|}{ MR-Miljø } & 5.951 & 6.084 & -134 & $-2,2 \%$ \\
\hline $3-3310-1$ & Dispositionsmidler - Miljø & 837 & 824 & 13 & $1,6 \%$ \\
\hline $3-3311-2$ & Miljøsektorens arbejdsgrupper & 3.044 & 3.110 & -66 & $-2,1 \%$ \\
\hline $3-3320-2$ & NEFCOS Miljøudviklingsfond & 1.514 & 1.604 & -90 & $-5,6 \%$ \\
\hline $3-6720-4$ & SVANEN - Nordisk miljömärkning & 555 & 546 & 9 & $1,6 \%$ \\
\hline
\end{tabular}




\begin{tabular}{crrrr}
\hline Opdelt på kategorier & $\mathbf{5 . 9 5 1}$ & $\mathbf{6 . 0 8 4}$ & $\mathbf{1 0 0 \%}$ & $\mathbf{1 0 0 \%}$ \\
\hline Projektmidler & 837 & 824 & $14,1 \%$ & $13,5 \%$ \\
Programlignende aktiviteter & 4.559 & 4.714 & $76,6 \%$ & $77,5 \%$ \\
Organisationsbidrag & 555 & 546 & $9,3 \%$ & $9,0 \%$
\end{tabular}

\begin{tabular}{llrrrr} 
& MR-Arbetsliv & $\begin{array}{c}\text { Budget } \\
\mathbf{2 0 1 4}\end{array}$ & $\begin{array}{c}\text { Budget } \\
\mathbf{2 0 1 3}\end{array}$ & \multicolumn{2}{c}{$\begin{array}{c}\text { Difference } \\
+/-\end{array}$} \\
\hline MR-A & $\mathbf{1 . 8 3 6}$ & $\mathbf{1 . 8 7 6}$ & $\mathbf{- 3 9}$ & $\mathbf{- 2 , 1 \%}$ \\
& & & & \\
& Projektmedel & 1.392 & 1.436 & -44 & $-3,0 \%$ \\
\hline $2-4110-1$ & Projektmidler i øvrigt - Arbejdsliv & 93 & 92 & 1 & $1,6 \%$ \\
$2-4111-2$ & Arbejdsliv faste udvalg & 669 & 724 & -55 & $-7,6 \%$ \\
$2-4120-2$ & Nordjobb & 417 & 411 & 7 & $1,6 \%$ \\
$2-4130-1$ & Kommunikation om arbejdsliv & 213 & 210 & 3 & $1,6 \%$ \\
& Institutioner & 444 & 440 & 4 & $1,0 \%$ \\
\hline $2-4180-3$ & Institut för vidareutb.inom arbetsmiljö & 444 & 440 & 4 & $1,0 \%$ \\
& (NIVA) & & & & \\
& & & & & \\
\hline Opdelt på & kategorier & $\mathbf{1 . 8 3 6}$ & $\mathbf{1 . 8 7 6}$ & $\mathbf{1 0 0 \%}$ & $\mathbf{1 0 0 \%}$ \\
\hline & Projektmidler & 306 & 301 & $16,7 \%$ & $16,1 \%$ \\
& Programlignende aktiviteter & 1.086 & 1.135 & $59,1 \%$ & $60,5 \%$ \\
& Institutioner & 444 & 440 & $24,2 \%$ & $23,5 \%$
\end{tabular}

\begin{tabular}{|c|c|c|c|c|c|}
\hline & MR-Finans & Budget & Budget & Diffe & ence \\
\hline & & 2014 & 2013 & $+/-$ & $\%$ \\
\hline MR-Fina & & 244 & 249 & -5 & $-1,9 \%$ \\
\hline $4-5210-1$ & Projektmedel- Ekonomi och finanspolitik & 244 & 249 & -5 & $-1,9 \%$ \\
\hline Opdelt p & kategorier & 244 & 249 & $100 \%$ & $100 \%$ \\
\hline & Projektmidler & 244 & 249 & $100 \%$ & $100 \%$ \\
\hline
\end{tabular}

\begin{tabular}{|c|c|c|c|c|c|}
\hline & \multirow[t]{2}{*}{ MR-Lag } & \multirow{2}{*}{$\begin{array}{c}\text { Budget } \\
2014\end{array}$} & \multirow{2}{*}{$\begin{array}{c}\text { Budget } \\
2013\end{array}$} & \multicolumn{2}{|c|}{ Difference } \\
\hline & & & & $+/-$ & $\%$ \\
\hline MR-Lag & & 186 & 190 & -4 & $-2,0 \%$ \\
\hline \multirow[t]{3}{*}{$1-7110-1$} & Projektmedel - Lagstiftning & 186 & 190 & -4 & $-2,0 \%$ \\
\hline & Opdelt på katgorier & 186 & 190 & $100 \%$ & $100 \%$ \\
\hline & Projektmidler & 186 & 190 & $100 \%$ & $100 \%$ \\
\hline
\end{tabular}




\begin{tabular}{|c|c|c|c|c|c|}
\hline & MR-SAM & Budget & Budget & Diffe & ence \\
\hline & & 2014 & 2013 & $+/-$ & $\%$ \\
\hline Internati & nalt samarbejde & 12.027 & 12.814 & -787 & $-6,1 \%$ \\
\hline $6-0820-2$ & Kunskapsuppbyggning och nätverk & 3.748 & 3.689 & 59 & $1,6 \%$ \\
\hline $6-0980-1$ & Partnerskab og grænseregionalt samarbejde & 327 & 835 & -508 & $-60,9 \%$ \\
\hline $6-0960-1$ & NGO-virksomhed i Østersøregionen & 835 & 822 & 13 & $1,6 \%$ \\
\hline $6-5280-2$ & Nopef & 2.002 & 2.152 & -149 & $-6,9 \%$ \\
\hline $6-0970-3$ & Ministerrådets kontorer i Nord-vest Rusland & 1.258 & 1.373 & -115 & $-8,4 \%$ \\
\hline $6-0810-3$ & $\begin{array}{l}\text { Ministerrådets kontorer i Estland, Letland og } \\
\text { Litauen }\end{array}$ & 1.568 & 1.544 & 23 & $1,5 \%$ \\
\hline $6-0910-1$ & Politiske initiativer & 0 & 132 & -132 & \\
\hline $6-0850-1$ & Internationellt samarbete & 232 & 0 & 232 & - \\
\hline $6-0870-1$ & Arktisk samarbeidsprogram & 1.251 & 1.299 & -47 & $-3,6 \%$ \\
\hline $6-0950-2$ & EHU/Hviderusland & 594 & 625 & -31 & $-4,9 \%$ \\
\hline 6-0990-1 & Samarbejde med Nordens naboer i Vest & 212 & 342 & -131 & $-38,2 \%$ \\
\hline Opdelt p & kategorier & 12.027 & 12.814 & $100 \%$ & $100 \%$ \\
\hline & Projektmidler & 2.856 & 3.430 & $23,8 \%$ & $26,8 \%$ \\
\hline & Programlignende aktiviteter & 4.342 & 4.314 & $36,1 \%$ & $33,7 \%$ \\
\hline & Institutioner & 4.828 & 5.069 & $40,1 \%$ & $39,6 \%$ \\
\hline
\end{tabular}

\begin{tabular}{|c|c|c|c|c|c|}
\hline & MR-SAM & Budget & Budget & Diffe & ence \\
\hline & & 2014 & 2013 & $+/-$ & $\%$ \\
\hline Samarbe & Isministrene & 14.392 & 14.928 & -536 & $-3,7 \%$ \\
\hline & Ministerrådets sekretariat (NMRS) & 10.483 & 10.832 & -349 & $-3,2 \%$ \\
\hline $5-0180-3$ & Ministerrådets sekretariat (NMRS) & 10.483 & 10.832 & -349 & $-3,2 \%$ \\
\hline & Nordisk Ministerråds fcellesaktiviteter & 3.909 & 4.097 & -188 & $-4,6 \%$ \\
\hline $5-0410-4$ & Föreningarna Nordens Förbund & 435 & 444 & -9 & $-2,0 \%$ \\
\hline $5-0425-4$ & Bidrag til Västnorden & 98 & 100 & -2 & $-2,0 \%$ \\
\hline $5-0435-1$ & Generalsekreterarens disponeringsreserv & 55 & 57 & -1 & $-1,9 \%$ \\
\hline $5-0460-1$ & Holdbart Norden & 408 & 416 & -8 & $-1,9 \%$ \\
\hline $5-1011-1$ & Informationsaktiviteter & 682 & 695 & -14 & $-2,0 \%$ \\
\hline $5-1012-1$ & Norden i Fokus & 593 & 609 & -16 & $-2,6 \%$ \\
\hline $5-1021-1$ & Internationale aktiviteter & 0 & 99 & -99 & \\
\hline $5-1030-2$ & Hallo Norden & 781 & 761 & 19 & $2,5 \%$ \\
\hline $5-1035-1$ & Grænsehindringer & 0 & 524 & -524 & - \\
\hline $5-1036-2$ & Grænsehindringsråd & 680 & 0 & 680 & \\
\hline $5-1050-2$ & Tjänstemannautbyte & 177 & 208 & -31 & \\
\hline $5-2055-1$ & Gränshindersforum & 0 & 184 & -184 & \\
\hline Opdelt p & kategorier & 14.392 & 14.928 & $100 \%$ & $100 \%$ \\
\hline & Projektmidler & 1.738 & 2.584 & $12,1 \%$ & $17,3 \%$ \\
\hline & Programlignende aktiviteter & 1.638 & 970 & $11,4 \%$ & $6,5 \%$ \\
\hline & Institutioner & 10.483 & 10.832 & $72,8 \%$ & $72,6 \%$ \\
\hline & Organisationsbidrag & 533 & 543 & $3,7 \%$ & $3,6 \%$ \\
\hline
\end{tabular}




\begin{tabular}{|c|c|c|c|c|c|}
\hline & MR-SAM & Budget & Budget & Diff & ence \\
\hline & & 2014 & 2013 & $+/-$ & $\%$ \\
\hline Prioriteri & gsbudgettet (TDKK) & 10.023 & 10.917 & -895 & $-8,9 \%$ \\
\hline & Formandskapspuljen, Island & 2.043 & 0 & 2.043 & 0 \\
\hline $7-8005-2$ & Den nordiska spellistan & 272 & 0 & 272 & - \\
\hline $7-8006-2$ & Välfärdsvakten & 409 & 0 & 409 & - \\
\hline $7-8007-2$ & Bioekonomi-satsningen & 1.362 & 0 & 1.362 & - \\
\hline & Formandskapspuljen, Sverige & 2.043 & 2.729 & -686 & $-25,1 \%$ \\
\hline $7-8001-2$ & NordMin & 1.362 & 1.365 & -3 & $-0,2 \%$ \\
\hline $7-8002-2$ & $\begin{array}{l}\text { Fler unga i arbete i Norden och arbetsmak- } \\
\text { nadsmötet }\end{array}$ & 0 & 682 & -682 & - \\
\hline $7-8003-2$ & $\begin{array}{l}\text { Förbättrade emissionsinventeringar av kortli- } \\
\text { vade klimatpåvekande luftföreningar }\end{array}$ & 272 & 273 & -1 & $-0,2 \%$ \\
\hline $7-8004-2$ & Lärande på arbetsplats & 409 & 409 & -1 & $-0,2 \%$ \\
\hline & Prioriteringspuljen & 5.937 & 8.188 & -2.251 & $-27,5 \%$ \\
\hline $7-8110-1$ & Testcenter & 111 & 68 & 43 & $62,7 \%$ \\
\hline $7-8111-2$ & Uddannelse og forskning inden for grøn vækst & 504 & 1.160 & -656 & $-56,6 \%$ \\
\hline $7-8112-1$ & Elmarknaden & 157 & 409 & -252 & $-61,6 \%$ \\
\hline $7-8113-2$ & $\begin{array}{l}\text { Grønne tekniske normer og standarder - Nor- } \\
\text { den som standardmaker }\end{array}$ & 436 & 273 & 163 & $59,7 \%$ \\
\hline $7-8114-2$ & Grøn offentlig indkøb & 340 & 273 & 68 & $24,8 \%$ \\
\hline $7-8115-2$ & $\begin{array}{l}\text { Utveckla tekniker och metoder för avfallshan- } \\
\text { tering }\end{array}$ & 903 & 955 & -52 & $-5,5 \%$ \\
\hline $7-8116-1$ & $\begin{array}{l}\text { Främja integrationen av miljö och klima i } \\
\text { utvecklingssamarbetet }\end{array}$ & 68 & 27 & 41 & $149,0 \%$ \\
\hline $7-8117-1$ & $\begin{array}{l}\text { Samordning och förstärkt finansiering av gröna } \\
\text { inversteringar och företag }\end{array}$ & 0 & 55 & -55 & - \\
\hline $7-8118-1$ & Särskilda prioriteringer Grön tillväxt & 67 & 0 & 67 & - \\
\hline $7-8210-2$ & Hållbar nordisk välfärd & 1.771 & 2.388 & -618 & $-25,9 \%$ \\
\hline $7-8211-1$ & $\begin{array}{l}\text { Fælles studie af den nordiske velfærdsmodels } \\
\text { udfordringer }\end{array}$ & 0 & 409 & -409 & - \\
\hline $7-8212-2$ & Välfärd och kost & 136 & 136 & 0 & $-0,2 \%$ \\
\hline $7-8310-2$ & Klimavenligt byggeri & 763 & 887 & -124 & $-14,0 \%$ \\
\hline $7-8311-2$ & Kultur og kreativitet - KreaNord initativet & 545 & 682 & -138 & $-20,2 \%$ \\
\hline $7-8312-2$ & $\begin{array}{l}\text { Offentlig-privat-partnerskab om plandeforæd- } \\
\text { ling i Norden }\end{array}$ & 68 & 96 & -27 & $-28,8 \%$ \\
\hline $7-8313-2$ & Ny Nordisk Mad & 68 & 136 & -68 & $-50,1 \%$ \\
\hline $7-8401-1$ & Kennedycenter & 0 & 205 & -205 & - \\
\hline $7-8402-1$ & Interering av jämställhetsperspektiv & 0 & 27 & -27 & - \\
\hline Opdelt på & kategorier & 10.023 & 10.917 & $100 \%$ & $100 \%$ \\
\hline & Projektmidler & 403 & 1.201 & $4,0 \%$ & $11,0 \%$ \\
\hline & Programlignende aktiviteter & 9.619 & 9.716 & $96,0 \%$ & $89,0 \%$ \\
\hline
\end{tabular}




\section{Sammenstilling af Budget 2014 og 2013 (løbende priser, TEUR)}

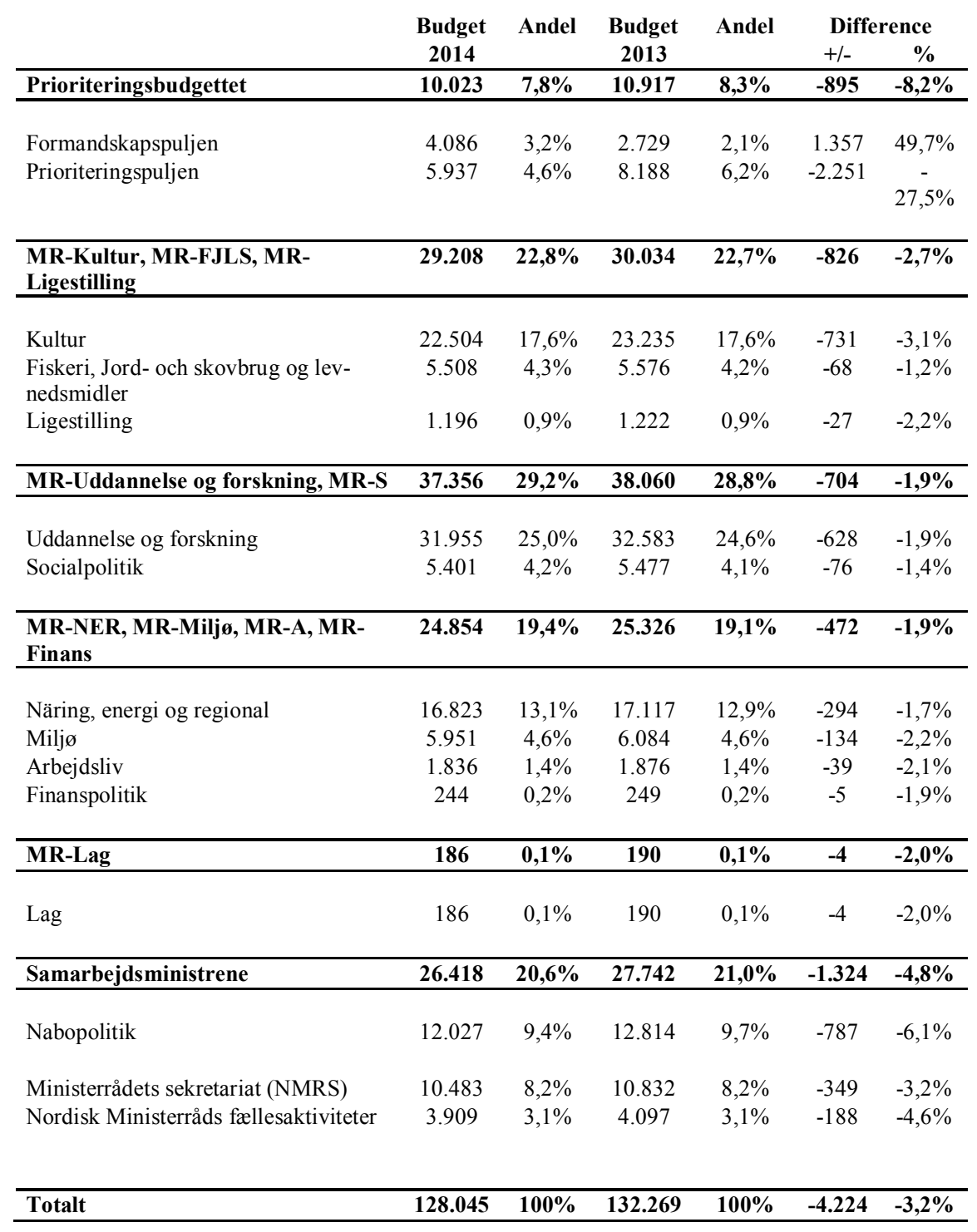




\section{Bilag 2 - Status 31. 122012 på budgetpostniveau}

\begin{tabular}{|c|c|c|c|c|c|c|}
\hline & & $\begin{array}{l}\text { Budget } \\
2012\end{array}$ & $\begin{array}{l}\text { Midler til } \\
\text { rådighed }\end{array}$ & $\begin{array}{c}\text { Anvendt i } \\
2012\end{array}$ & $\begin{array}{c}\text { Disp. } \\
\%\end{array}$ & $\begin{array}{c}\text { Ikke } \\
\text { disp. } \\
\text { midler }\end{array}$ \\
\hline \multicolumn{2}{|c|}{ Prioriteringsbudget } & $\mathbf{0}$ & $\mathbf{0}$ & -1.400 & - & 1.400 \\
\hline 8112 & Elmarknaden & 0 & 0 & -500 & - & 500 \\
\hline 8116 & Främja integrationen av miljö & 0 & 0 & -300 & - & 300 \\
\hline 8117 & Samordning och förstärk finan & 0 & 0 & -100 & - & 100 \\
\hline 8114 & Grøn offentlig indkøb & 0 & 0 & -500 & - & 500 \\
\hline \multicolumn{2}{|c|}{ Globaliseringsinitiativer } & 73.724 & 94.561 & 88.187 & $93 \%$ & 6.374 \\
\hline & Projektmidler & 35.040 & 42.577 & 39.362 & $92 \%$ & 3.215 \\
\hline 2020 & Globaliseringsforum/Grøn Vækst & 8.144 & 8.919 & 7.366 & $83 \%$ & 1.554 \\
\hline 2040 & Gemensamt nordiskt EnergiExpo & 0 & 200 & 0 & $0 \%$ & 200 \\
\hline 2042 & Energi og transport inkl. uppf & 9.162 & 10.587 & 10.540 & $100 \%$ & 47 \\
\hline 2045 & EXPO 2010 Shanghai & 0 & 200 & 0 & $0 \%$ & 200 \\
\hline 2055 & Gränshindersforum & 1.446 & 2.180 & 1.934 & $89 \%$ & 246 \\
\hline 2062 & e-Science & 8.144 & 8.144 & 8.144 & $100 \%$ & 0 \\
\hline 2065 & Främjandet av högre utbildning & 6.108 & 8.762 & 8.000 & $91 \%$ & 762 \\
\hline 2070 & God uppläring av unga och vuxn & 2.036 & 3.343 & 3.139 & $94 \%$ & 205 \\
\hline \multirow[t]{2}{*}{3000} & Puljen till nya globaliserings & 0 & 241 & 241 & $100 \%$ & 0 \\
\hline & Programlignende aktiviteter & 38.684 & 51.984 & 48.825 & $94 \%$ & 3.159 \\
\hline 2025 & Nordisk Toppforskning & 2.036 & 2.111 & 1.704 & $81 \%$ & 407 \\
\hline 2030 & Innovationsrepresent. i Asien & 1.527 & 1.669 & 1.500 & $90 \%$ & 169 \\
\hline 2060 & NORIA & 2.036 & 11.048 & 10.640 & $96 \%$ & 407 \\
\hline 2075 & Konsekvenser av klimatförändr. & 4.072 & 4.072 & 4.072 & $100 \%$ & 0 \\
\hline 2076 & Harmonisering av den nordiska & 1.527 & 1.527 & 1.500 & $98 \%$ & 27 \\
\hline 2080 & Kultur och kreativitet & 6.108 & 7.877 & 6.655 & $84 \%$ & 1.222 \\
\hline 2085 & Hälsa och välfärd & 13.234 & 15.514 & 14.753 & $95 \%$ & 760 \\
\hline 2090 & Klimatvänligt byggeri & 8.144 & 8.167 & 8.000 & $98 \%$ & 167 \\
\hline \multicolumn{2}{|c|}{ MR-Kultur, MR-Ligestilling, MR-FJL } & 219.480 & 228.421 & 225.785 & $99 \%$ & 2.635 \\
\hline \multicolumn{2}{|c|}{ MR-Kultur } & 169.972 & 174.532 & 172.985 & $99 \%$ & 1.548 \\
\hline & Projektmidler & 15.710 & 17.055 & 16.516 & $97 \%$ & 539 \\
\hline 2203 & Dispostionsmidler Kultur & 12.425 & 12.475 & 12.215 & $98 \%$ & 259 \\
\hline 2204 & Nordisk Kulturforum & 1.627 & 2.694 & 2.415 & $90 \%$ & 279 \\
\hline 2207 & Kulturmin. globaliseringsinds. & 1.658 & 1.716 & 1.716 & $100 \%$ & 0 \\
\hline 2210 & Nordiskt idrottssamarbete & 0 & 170 & 170 & $100 \%$ & 0 \\
\hline
\end{tabular}




\begin{tabular}{ccccc} 
Budget & $\begin{array}{c}\text { Midler til } \\
\text { rå̊dighed }\end{array}$ & $\begin{array}{c}\text { Anvendt i } \\
2012\end{array}$ & $\begin{array}{c}\text { Disp. } \\
\%\end{array}$ & $\begin{array}{c}\text { Ikke } \\
\text { disp. } \\
\text { midler }\end{array}$ \\
\hline
\end{tabular}

\begin{tabular}{|c|c|c|c|c|c|c|}
\hline & Programlignende aktiviteter & 114.077 & 117.191 & 116.284 & $99 \%$ & 907 \\
\hline 2205 & Nordisk kulturfond & 34.650 & 34.650 & 34.650 & $100 \%$ & 0 \\
\hline 2206 & Nordisk Råds priser & 2.376 & 3.273 & 3.273 & $100 \%$ & 0 \\
\hline 2212 & Nordisk Børne- og Ungdomskomit & 6.085 & 7.874 & 7.422 & $94 \%$ & 451 \\
\hline 2221 & Nordisk computerspilprogram & 9.162 & 9.273 & 9.162 & $99 \%$ & 111 \\
\hline 2222 & Nordisk Film- och TV-fond & 26.543 & 26.543 & 26.466 & $100 \%$ & 78 \\
\hline 2223 & Nordisk Journalistisk Efterudd & 2.628 & 2.628 & 2.628 & $100 \%$ & 0 \\
\hline 2251 & Kunst- og kulturprogrammet & 17.942 & 18.219 & 17.992 & $99 \%$ & 227 \\
\hline 2253 & Nordisk oversætterstøtte & 2.921 & 2.921 & 2.921 & $100 \%$ & 0 \\
\hline \multirow[t]{2}{*}{2254} & Mobilitets- og residensprogram & 11.770 & 11.810 & 11.770 & $100 \%$ & 40 \\
\hline & Institutioner & 40.185 & 40.287 & 40.185 & $100 \%$ & 102 \\
\hline 2228 & NORDICOM & 2.951 & 2.951 & 2.951 & $100 \%$ & 0 \\
\hline 2272 & Nordens hus på Färöarna & 13.462 & 13.462 & 13.462 & $100 \%$ & 0 \\
\hline 2274 & Nordens institut på Åland & 2.941 & 2.941 & 2.941 & $100 \%$ & 0 \\
\hline 2277 & Nordens institut på Grönland & 6.282 & 6.282 & 6.282 & $100 \%$ & 0 \\
\hline 2548 & Kulturkontakt Nord (tidl. NIFI & 10.969 & 10.969 & 10.969 & $100 \%$ & 0 \\
\hline 2234 & Samisk samarbeid & 3.580 & 3.682 & 3.580 & $97 \%$ & 102 \\
\hline \multicolumn{2}{|c|}{ MR-Ligestilling } & 8.957 & 10.320 & 9.855 & $95 \%$ & 465 \\
\hline & Projektmidler & 3.657 & 5.020 & 4.555 & $91 \%$ & 465 \\
\hline \multirow[t]{2}{*}{4410} & Projektmedel - Jämställdhet & 3.657 & 5.020 & 4.555 & $91 \%$ & 465 \\
\hline & Programlignende aktiviteter & 5.300 & 5.300 & 5.300 & $100 \%$ & 0 \\
\hline 4480 & NIKK & 5.300 & 5.300 & 5.300 & $100 \%$ & $\overline{0}$ \\
\hline \multicolumn{2}{|c|}{ MR-FJLS } & 40.551 & 43.568 & 42.946 & $99 \%$ & 623 \\
\hline & Projektmidler & 12.415 & 15.427 & 14.810 & $96 \%$ & 618 \\
\hline 6310 & Projektmidler Skovbrug & 389 & 589 & 476 & $81 \%$ & 113 \\
\hline 6410 & Projektmildler - fællespulje & 0 & 0 & 0 & $0 \%$ & 0 \\
\hline 6510 & Projektmidler Jordbrug & 365 & 569 & 545 & $96 \%$ & 25 \\
\hline 6610 & Projektmedel - Fiskeri & 6.130 & 7.093 & 6.886 & $97 \%$ & 207 \\
\hline 6810 & Projektmedel - Levnedsmidler & 3.877 & 5.495 & 5.240 & $95 \%$ & 255 \\
\hline 6820 & Forskning - levnedsmidler & 1.113 & 1.113 & 1.113 & $100 \%$ & 0 \\
\hline \multirow[t]{2}{*}{6830} & H.plan- bedre helse+livskv. & 541 & 568 & 550 & $97 \%$ & 18 \\
\hline & Programlignende aktiviteter & 28.136 & 28.141 & 28.136 & $100 \%$ & 5 \\
\hline 6420 & Ny nordisk Mad & 2.327 & 2.327 & 2.327 & $100 \%$ & 0 \\
\hline 6520 & Nor. kontaktorgan för jordbrug & 809 & 809 & 809 & $100 \%$ & 0 \\
\hline 6581 & Samnordisk skogsforskning, SNS & 5.413 & 5.413 & 5.413 & $100 \%$ & 0 \\
\hline 6585 & Nordisk Genr. Center, NordGen & 19.587 & 19.592 & 19.587 & $100 \%$ & 5 \\
\hline
\end{tabular}




\section{Budget Midler til Anvendt i Disp. Ikke \\ 2012 rådighed $2012 \quad \%$ disp. midler}

\begin{tabular}{|c|c|c|c|c|c|c|}
\hline \multicolumn{2}{|c|}{ MR-U. MR-S } & 274.903 & 288.040 & 277.066 & $96 \%$ & 10.973 \\
\hline \multirow[t]{2}{*}{ MR-U } & & 235.093 & 244.791 & 234.179 & $96 \%$ & 10.612 \\
\hline & Projektmidler & 13.767 & 23.440 & 21.772 & $93 \%$ & 1.668 \\
\hline 2505 & Utbildning och forskning & 3.592 & 8.356 & 8.227 & $98 \%$ & 129 \\
\hline 2510 & Nordiskt skolsamarbete (NSS) & 1.651 & 2.656 & 2.444 & $92 \%$ & 212 \\
\hline 2520 & Rådg.gr. for voksnes læring & 1.175 & 1.688 & 1.550 & $92 \%$ & 138 \\
\hline 2530 & Rådg.gr. for högre utbildning & 1.391 & 2.345 & 2.067 & $88 \%$ & 278 \\
\hline 2540 & Stöd till nordiska språkråd & 0 & 250 & 250 & $100 \%$ & 0 \\
\hline 2544 & De nordiske sprogsamarbejde & 5.357 & 5.611 & 5.100 & $91 \%$ & 510 \\
\hline 2553 & Politikudvikling, Videnssamfun & 601 & 1.895 & 1.695 & $89 \%$ & 200 \\
\hline \multirow[t]{2}{*}{3110} & Nordiska forskningspolitiska & 0 & 639 & 439 & $69 \%$ & 200 \\
\hline & Programlignende aktiviteter & 107.204 & 107.229 & 98.285 & $92 \%$ & 8.944 \\
\hline 2513 & Nordplus rammeprogram & 72.142 & 72.142 & 63.225 & $88 \%$ & 8.917 \\
\hline 2543 & Nordplus Sprog og Kultur & 0 & 0 & 0 & $0 \%$ & 0 \\
\hline 2545 & Nordenundervisning i utlandet & 1.080 & 1.080 & 1.080 & $100 \%$ & 0 \\
\hline 3127 & Politikudvikling voksnes lærin & 6.874 & 6.874 & 6.874 & $100 \%$ & 0 \\
\hline 3140 & Nordisk komitè for Bioetikk & 1.002 & 1.027 & 1.000 & $97 \%$ & 27 \\
\hline 3180 & Nordisk Inst. for Teor. fysik & 10.718 & 10.718 & 10.718 & $100 \%$ & 0 \\
\hline 3181 & Nordiska Inst. for Sjörett & 3.194 & 3.194 & 3.194 & $100 \%$ & 0 \\
\hline 3182 & Nordisk Institutt for Asiastud & 5.064 & 5.064 & 5.064 & $100 \%$ & 0 \\
\hline 3184 & Nordisk vulkanologisk institut & 5.174 & 5.174 & 5.174 & $100 \%$ & 0 \\
\hline \multirow[t]{2}{*}{3185} & Nordisk Samisk Institutt (NSI) & 1.956 & 1.956 & 1.956 & $100 \%$ & 0 \\
\hline & Institutioner & 112.931 & 112.931 & 112.931 & $100 \%$ & 0 \\
\hline \multirow[t]{2}{*}{3100} & NordForsk & 112.931 & 112.931 & 112.931 & $100 \%$ & 0 \\
\hline & Organisationsbidrag & 1.191 & 1.191 & 1.191 & $100 \%$ & 0 \\
\hline 2534 & Bidrag till Nor. Sommaruniv. & 1.191 & 1.191 & 1.191 & $100 \%$ & 0 \\
\hline \multirow[t]{2}{*}{ MR-S } & & 39.810 & 43.249 & 42.887 & $99 \%$ & 361 \\
\hline & Projektmidler & 8.658 & 12.091 & 11.735 & $97 \%$ & 356 \\
\hline 4310 & Projekmedel - Social- och häls & 5.654 & 9.087 & 8.731 & $96 \%$ & 356 \\
\hline 4320 & Nordiska Handikappolitiska Råd & 1.122 & 1.122 & 1.122 & $100 \%$ & 0 \\
\hline \multirow[t]{2}{*}{4340} & Nomesko og Nososko & 1.882 & 1.882 & 1.882 & $100 \%$ & 0 \\
\hline & Programlignende aktiviteter & 10.590 & 10.596 & 10.590 & $100 \%$ & 6 \\
\hline 4382 & Nordisk Inst. for Odontolologi & 10.590 & 10.596 & 10.590 & $100 \%$ & 6 \\
\hline
\end{tabular}




\begin{tabular}{ccccc}
$\begin{array}{c}\text { Budget } \\
2012\end{array}$ & $\begin{array}{c}\text { Midler til } \\
\text { rådighed }\end{array}$ & $\begin{array}{c}\text { Anvendt i } \\
2012\end{array}$ & $\begin{array}{c}\text { Disp. } \\
\%\end{array}$ & $\begin{array}{c}\text { Ikke } \\
\text { disp. } \\
\text { midler }\end{array}$ \\
\hline
\end{tabular}

\begin{tabular}{|c|c|c|c|c|c|c|}
\hline & Institutioner & 20.562 & 20.562 & 20.562 & $100 \%$ & 0 \\
\hline 4380 & Nordiskt Välfärdscenter & 20.562 & 20.562 & 20.562 & $100 \%$ & 0 \\
\hline \multicolumn{2}{|c|}{ MR-NER, MR-A, MR-Finans, MR-Miljø } & 182.874 & 194.159 & 190.619 & $98 \%$ & 3.540 \\
\hline \multicolumn{2}{|c|}{ MR-Ner } & 121.546 & 125.580 & 124.130 & $99 \%$ & 1.450 \\
\hline & Projektmidler & 7.704 & 9.883 & 9.034 & $91 \%$ & 849 \\
\hline 5140 & Projektmidler Näring & 2.077 & 2.830 & 2.739 & $97 \%$ & 90 \\
\hline 5141 & Projektmidler Energi & 2.180 & 3.177 & 3.017 & $95 \%$ & 160 \\
\hline \multirow[t]{2}{*}{5143} & Projektmidler Regional & 3.447 & 3.876 & 3.277 & $85 \%$ & 599 \\
\hline & Programlignende aktiviteter & 14.133 & 14.989 & 14.387 & $96 \%$ & 601 \\
\hline 5142 & Arbejdsgrupper - Energi & 2.077 & 2.585 & 2.280 & $88 \%$ & 304 \\
\hline 5145 & Arbejdsgrupper under regional & 1.527 & 1.742 & 1.742 & $100 \%$ & 0 \\
\hline \multirow[t]{2}{*}{5160} & Grænsekomiteer & 10.529 & 10.662 & 10.365 & $97 \%$ & 297 \\
\hline & Institutioner & 93.204 & 94.204 & 94.204 & $100 \%$ & 0 \\
\hline 3220 & Nordisk Energiforskning (NEF) & 5.808 & 6.808 & 6.808 & $100 \%$ & 0 \\
\hline 5180 & Nordisk InnovationsCenter,NICe & 76.469 & 76.469 & 76.469 & $100 \%$ & 0 \\
\hline \multirow[t]{2}{*}{6180} & Nordregio & 10.927 & 10.927 & 10.927 & $100 \%$ & 0 \\
\hline & Organisationsbidrag & 6.505 & 6.505 & 6.505 & $100 \%$ & 0 \\
\hline 5151 & NORA & 6.505 & 6.505 & 6.505 & $100 \%$ & $\overline{0}$ \\
\hline \multicolumn{2}{|c|}{ MR-Finans } & 1.822 & 1.887 & 1.722 & $91 \%$ & 165 \\
\hline & Projektmidler & 1.822 & 1.887 & 1.722 & $91 \%$ & 165 \\
\hline 5210 & Projekt-Ekonomi och finans & 1.822 & 1.887 & 1.722 & $91 \%$ & 165 \\
\hline \multicolumn{2}{|l|}{ MR-A } & 13.527 & 15.444 & 14.416 & $93 \%$ & 1.028 \\
\hline & Projektmidler & 2.206 & 2.767 & 2.738 & $99 \%$ & 29 \\
\hline 4110 & Prosjektmedel- Arbejdsliv & 611 & 1.170 & 1.143 & $98 \%$ & 27 \\
\hline \multirow[t]{2}{*}{4130} & Informationsprojektet & 1.595 & 1.597 & 1.595 & $100 \%$ & 2 \\
\hline & Programlignende aktiviteter & 8.115 & 9.471 & 8.472 & $89 \%$ & 1.000 \\
\hline 4111 & Arbejdsliv fasteudvalg & 5.305 & 6.383 & 5.462 & $86 \%$ & 922 \\
\hline \multirow[t]{2}{*}{4120} & Nordjobb & 2.810 & 3.088 & 3.010 & $97 \%$ & 78 \\
\hline & Institutioner & 3.206 & 3.206 & 3.206 & $100 \%$ & 0 \\
\hline 4180 & Inst. för vid.utb.inom arbetsm & 3.206 & 3.206 & 3.206 & $100 \%$ & 0 \\
\hline
\end{tabular}




\section{Budget Midler til Anvendt i Disp. Ikke \\ 2012 rådighed $2012 \quad \%$ disp. \\ midler}

\begin{tabular}{|c|c|c|c|c|c|c|}
\hline \multicolumn{2}{|c|}{ MR-Miljø } & \multirow{2}{*}{$\begin{array}{r}\mathbf{4 4 . 5 8 6} \\
6.749\end{array}$} & \multirow{2}{*}{$\begin{array}{l}49.372 \\
11.064\end{array}$} & \multirow{2}{*}{$\begin{array}{l}\mathbf{4 8 . 7 0 0} \\
10.419\end{array}$} & \multirow{2}{*}{$\begin{array}{l}\mathbf{9 9 \%} \\
94 \%\end{array}$} & \multirow{2}{*}{$\begin{array}{l}672 \\
646\end{array}$} \\
\hline & Projektmidler & & & & & \\
\hline \multirow[t]{2}{*}{3310} & Projektmedel - Miljö & 6.749 & 11.064 & 10.419 & $94 \%$ & 646 \\
\hline & Programlignende aktiviteter & 35.256 & 35.725 & 35.700 & $100 \%$ & 25 \\
\hline 3311 & Miljøsektorens arbejdsgrupper & 23.501 & 23.949 & 23.945 & $100 \%$ & 4 \\
\hline \multirow[t]{2}{*}{3320} & NEFCOS Miljøudviklingsfond & 11.755 & 11.776 & 11.755 & $100 \%$ & 21 \\
\hline & Organisationsbidrag & 2.581 & 2.583 & 2.581 & $100 \%$ & 2 \\
\hline 6720 & SVANEN - Nordisk miljömärkning & 2.581 & 2.583 & 2.581 & $100 \%$ & 2 \\
\hline \multicolumn{2}{|c|}{ MR-Lov } & 1.393 & 1.875 & 1.652 & $88 \%$ & 223 \\
\hline & Projektmidler & 1.393 & 1.875 & 1.652 & $88 \%$ & 223 \\
\hline 7110 & Projektmedel - Lagstiftning & 1.393 & 1.875 & 1.652 & $88 \%$ & 223 \\
\hline \multicolumn{2}{|c|}{ Nabopolitik } & 95.147 & 112.303 & 105.334 & $94 \%$ & 6.969 \\
\hline & Projektmidler & 25.912 & 34.933 & 31.113 & $89 \%$ & 3.819 \\
\hline 790 & Grænseregionalt samarbejde & 0 & 41 & 0 & $0 \%$ & 41 \\
\hline 800 & Gennemførsel af retningslinier & 0 & 95 & 0 & $0 \%$ & 95 \\
\hline 870 & Arktisk samarbeidsprogram & 9.717 & 9.909 & 9.462 & $95 \%$ & 446 \\
\hline 910 & Politiske initiativer & 1.142 & 1.372 & 1.144 & $83 \%$ & 228 \\
\hline 940 & Barentsregionen og m. frivilli & 0 & 3 & 0 & $0 \%$ & 3 \\
\hline 960 & NGO-virksomhed i Østersøregion & 6.025 & 8.046 & 6.841 & $85 \%$ & 1.205 \\
\hline 980 & Partnerskab og grænseregionalt & 6.320 & 11.248 & 9.984 & $89 \%$ & 1.264 \\
\hline \multirow[t]{2}{*}{990} & Samarb.m. Nordens naboer Vest & 2.708 & 4.220 & 3.683 & $87 \%$ & 537 \\
\hline & Programlignende aktiviteter & 32.015 & 38.588 & 36.233 & $94 \%$ & 2.355 \\
\hline 820 & Kunskapsuppbyggning och nätver & 27.235 & 33.038 & 31.558 & $96 \%$ & 1.480 \\
\hline \multirow[t]{2}{*}{950} & EHU/Hviderusland & 4.780 & 5.550 & 4.674 & $84 \%$ & 876 \\
\hline & Institutioner & 37.220 & 38.783 & 37.988 & $98 \%$ & 794 \\
\hline 810 & MR-kontorer i Estl.Letl.og Lit & 11.295 & 11.602 & 11.469 & $99 \%$ & 132 \\
\hline 970 & Ministerrådets kontorer i Nord & 10.043 & 11.299 & 10.637 & $94 \%$ & 662 \\
\hline 5280 & Nordiska Projektexportfonden & 15.882 & 15.882 & 15.882 & $100 \%$ & 0 \\
\hline \multicolumn{2}{|c|}{ Samarbejdsministrene } & 36.124 & 41.553 & 38.199 & $92 \%$ & 3.354 \\
\hline & Projektmidler & 23.710 & 28.402 & 25.308 & $89 \%$ & 3.094 \\
\hline 435 & Generalsekreterarens disponeri & 415 & 628 & 428 & $68 \%$ & 200 \\
\hline 445 & Formandsskabspuljen & 6.022 & 7.987 & 7.346 & $92 \%$ & 641 \\
\hline
\end{tabular}




\begin{tabular}{|c|c|c|c|c|c|c|}
\hline & & $\begin{array}{c}\text { Budget } \\
2012\end{array}$ & $\begin{array}{l}\text { Midler til } \\
\text { rådighed }\end{array}$ & $\begin{array}{c}\text { Anvendt i } \\
2012\end{array}$ & $\begin{array}{c}\text { Disp. } \\
\%\end{array}$ & $\begin{array}{c}\text { Ikke } \\
\text { disp. } \\
\text { midler }\end{array}$ \\
\hline 450 & Stöd till frivillig sektorn & 0 & 42 & 42 & $100 \%$ & 0 \\
\hline 460 & Holdbart Norden & 3.047 & 3.363 & 3.195 & $95 \%$ & 168 \\
\hline 461 & Nordisk sikkerhedspolitiskt Fo & 0 & 240 & 40 & $17 \%$ & 200 \\
\hline 1011 & Informationsaktiviteter & 5.096 & 5.588 & 4.765 & $85 \%$ & 823 \\
\hline 1012 & Norden I Fokus & 4.461 & 5.174 & 5.098 & $99 \%$ & 76 \\
\hline 1021 & Internationale aktiviteter & 727 & 1.025 & 825 & $80 \%$ & 200 \\
\hline 1035 & Grænsehindringer & 3.942 & 4.354 & 3.569 & $82 \%$ & 785 \\
\hline \multirow[t]{2}{*}{1040} & Översättning och tolkning & 0 & 0 & 0 & $39 \%$ & 0 \\
\hline & Programlignende aktiviteter & 8.433 & 9.170 & 8.910 & $97 \%$ & 260 \\
\hline 500 & Pulje til NMR støtte til Isl. & 1.527 & 1.629 & 1.527 & $94 \%$ & 102 \\
\hline 1030 & Hallo Norden & 5.379 & 5.404 & 5.309 & $98 \%$ & 95 \\
\hline \multirow[t]{2}{*}{1050} & Tjänstemannautbyte & 1.527 & 2.138 & 2.074 & $97 \%$ & 64 \\
\hline & Organisationsbidrag & 3.981 & 3.981 & 3.981 & $100 \%$ & 0 \\
\hline 410 & Föreningarna Nordens Förbund & 3.250 & 3.250 & 3.250 & $100 \%$ & $\overline{0}$ \\
\hline 425 & Bidrag til Västnorden & 731 & 731 & 731 & $100 \%$ & 0 \\
\hline \multicolumn{2}{|c|}{ Aktiviteter med selvstendigt regnskab } & 79.220 & 79.220 & 79.220 & $100 \%$ & $\mathbf{0}$ \\
\hline & I alt & 79.220 & 79.220 & 79.220 & $100 \%$ & 0 \\
\hline 180 & Ministerrådssekretariatet & 79.220 & 79.220 & 79.220 & $100 \%$ & 0 \\
\hline \multicolumn{2}{|c|}{ TOTAL } & 961.472 & 1.038 .256 & 1.003 .011 & $97 \%$ & 35.245 \\
\hline
\end{tabular}




\section{Bilag 3 - Forklaringer til Budgetstruktur og Budgetpost- kategorier}
Hoved- $\quad$ Budgettets hovedinddeling er det enkelte ministerråd. inddeling Præsentationen af hvert ministerråd indledes med en be- skrivelse af hele arbejdet med fokus på politiske målsæt- ninger, nye initiativer og ændringer i forhold til foregåen- de budgetår.

Budgetposter De enkelte budgetposter præsenteres ensartet indholdsmæssigt ved hjælp af fire budgetposttyper; 1) Projektmidler, 2) Programlignende aktiviteter som rummer samarbejdsorganer, rene programmer, støtteordninger/samarbejdsorgan og arbejdsgrupper 3) Institutioner/virksomheder som styres gennem mål - og resultatkontrakter samt 4) organisationsbidrag.

Nummerering Hver budgetpost har en 6 cifret nummerering. Det første ciffer er samarbejdsområde, anden til sjette ciffer er løbenummer indenfor ministerrådet. Det sidste ciffer viser hvilken type budgetpost det er; $1=$ projektmidler, $2=$ Programlignende aktiviteter, 3 = institution, 4 = organisationsbidrag.

\section{Specielle} I budgetpostene for projektmidler viser rubrikken rubrikker Disp./Bud12, hvor stor andel af 12-budgettet i procent, som er disponeret i løbet af 2012. En disponering er en beslutning om at bruge penge fra en budgetpost til et bestemt formål. Det disponerede beløb kan udbetales til formålet i budgetåret og i de 2 på følgende år, og Nordisk Ministerråd har en forpligtelse overfor det angivne formål i denne tidsperiode. En ikke udbetalt disposition vil efter 3 år blive indtægtsført i ministerrådets regnskab og tilbagebetalt til landene.

For så vidt angår videreførselsreglen for udisponerede midler på budgetpostniveau, så blev reglerne, som led i 
budget-moderniseringsarbejdet, ændret fra og med regnskabsåret 2007. Herefter er det kun være muligt at videreføre $20 \%$ af årets bevilling på en budgetpost, dog med en minimumsgrænse på 200 TDKK.

I budgetposterne for institutioner styret med resultatkontrakt viser rubrikken, NMR fin. 12 den procentvise andel af institutionens totale indtægter i 2012 som blev finansieret af Nordisk Ministerråd (fra regnskabet). Finansieringen fra Nordisk Ministerråd omfatter både basisbevilling og eventuelle projektmidler.

I rubrikken "kontraktstatus" redegøres for institutions målopfyldelse f.s.v.a. de faglige mål i resultatkontrakterne. I rubrikken "økonomi" fremgår sekretariatets bemærkninger til regnskabsaflæggelsen og intuitionens økonomiske situation for 2012 . 


\section{Bilag 4 - Økonomiske delegeringsregler i Nordisk Ministerråd}

På samarbejdsministrenes møde den 26. februar 2007 vedtog man en tilføjelse til Nordisk Ministerråds økonomireglement, hvorefter hvert enkelt ministerråd skal fastsætte egne retningslinjer for den økonomiske dispositionsret. Nedenstående tabel viser delegeringsreglerne for de forskellige ministerråd.

\begin{tabular}{|l|c|l|}
\hline $\begin{array}{l}\text { Beslutningsorgan } \\
\text { MR/EK }\end{array}$ & Belobsgraense & $\begin{array}{l}\text { Andre disponenter end } \\
\text { EK/MR og eventuel be- } \\
\text { lobsgraense }\end{array}$ \\
\hline MR-Kultur ${ }^{1)}$ & $>=1$ MDKK & \\
\hline EK-Kultur & $<1$ MDKK & \\
\hline & $>=1$ MDKK & \\
\hline MR-Jäm ${ }^{2)}$ & $<1$ MDKK & \\
\hline EK-Jäm & $>=1$ MDKK & \\
\hline MR-Lag ${ }^{3)}$ & $<1$ MDKK & \\
\hline EK-Lag & $>=1$ MDKK & \\
\hline & $<1$ MDKK & \\
\hline MR-U ${ }^{3)}$ & & \\
\hline EK-U & $\begin{array}{l}\text { Alle beslutnin- } \\
\text { ger uanset beløb }\end{array}$ & \\
\hline MR-A & \\
\hline EK-A & & \\
\hline & $\begin{array}{c}\text { Alle beslutnin- } \\
\text { ger uanset beløb }\end{array}$ & \\
\hline MR-NER & & \\
\hline EK-NE og EK-R & & \\
\hline & $\begin{array}{c}\text { Alle beslutnin- } \\
\text { ger uanset beløb }\end{array}$ & \\
\hline MR-S ${ }^{5)}$ & & \\
\hline EK-S & Alle beslutnin- & \\
\hline MR-Finans & & \\
\hline EK-Finans & & \\
\hline
\end{tabular}




\begin{tabular}{|l|c|l|}
\hline & ger uanset beløb & \\
\hline MR-M & & \\
\hline EK-M & $\begin{array}{c}\text { Alle beslutnin- } \\
\text { ger uanset beløb }\end{array}$ & \\
\hline MR-FJLS & & \\
\hline EK-FJLS & Alle beslutnin- & \\
\hline ger uanset beløb. & \\
\hline MR-SAM & & \\
\hline NSK & $>1$ MDKK & \\
\hline
\end{tabular}

1) Beslutningen indeholder endvidere en bestemmelse om at Generelsekretæren kan bevilge indtil 500 TDKK fra sektorens dispositionsmidler.

2) Beslutningen indeholder endvidere en bestemmelse om at Generalsekretæren kan bevilge indtil 300 TDKK af sektorens midler

3) Beslutningen indeholder endvidere en bestemmelse om at Generalsekretæren kan bevilge indtil 750 TDKK af sektorens midler.

4) Beslutningen indeholder endvidere en bestemmelse om at Generalsekretæren kan bevilge indtil 50 TDKK per gang fra sektorens midler og bevilge totalt 100 TDKK på hvert af områderne næring, energi og regional.

5) Beslutningen indeholder endvidere en bestemmelse om at Generalsekretæren kan bevilge indtil 50 TDKK fra sektorens dispositionsmidler.

6) Gælder for beslutninger under Holdbart Norden 5-0460-1. På Holdbart Norden er der endvidere taget beslutning om at Generalsekretæren kan disponere indtil 300 TDKK (NSK beslutning 10/10). På området Internationalt samarbejde varierer beløbsgrænserne på budgetposter. Der henvises til MRSAM beslutninger 42/08 og 39/09. 


\section{Bilag 5 - Förteckning över förkortningar}

AMAP

BHSF

CSR

CSSB

CSW

DTU

EBSCO

EFTA

EHU

ENIC

ENS

ERA

ESOF

EU

EQF

EØS

FAO

FILI

FN

FNF

FoU

GF

HELCOM

HÖGUT

ICCS

ICT

IEA

ISCED

$\mathrm{KKN}$

$\mathrm{KTH}$
Arctic monitoring and assessment programme

Barents Hot-Spot Facility

Corporate Social Responsibility

Center for Systems and Synthetic Biology

Committee on the status of women

Danmarks tekniska universitet

eBook Subscription Collection

European Free Trade Association

European Humanities University

European Network of Information Centres in the

European Region

Expertgruppen Nordiskt Språkråd

European Research Area

Euro Science Open Forum

Europeiska Unionen

European Qualifications Framework

Europeisk Østersøsamarbejde

Food and Agriculture Oranization

Finnish Literature Exchange

Förenta Nationerna

Föreningarna Nordens Förbund

Forsøgs- og Udviklingsprojekter

Gränshinderforum

Helsingfors Kommissionen

Rådgivningsgruppen för Högre Utbildning

International Civic and Citizenship Education

Study

Information and Communication Technology

International Energy Agency

International Standard Classification of Education

KulturKontaktNord

Kungliga Tekniska Högskolan 


$\begin{array}{ll}\text { LRTAP } & \text { Long-Range Transboundary Air Pollution } \\ \text { LTU } & \text { Luleå tekniska Universitet } \\ \text { MR-A } & \text { Ministerrådet för Arbetsliv } \\ \text { MR-Finans } & \text { Ministerrådet för Ekonomi- och Finanspolitik } \\ \text { MR-FJLS } & \text { Ministerrådet för Fiskeri, Havsbruk, Jordbruk, } \\ & \text { Livsmedel och Skogsbruk } \\ \text { MR-Jäm } & \text { Ministerrådet för Jämställdhet } \\ \text { MR-K } & \text { Ministerrådet för Kultur } \\ \text { MR-Lag } & \text { Ministerrådet för Lagstiftning } \\ \text { MR-M } & \text { Ministerrådet för Miljö } \\ \text { MR-NER } & \text { Ministerrådet för Näring, Energi och Regionalpoli- } \\ \text { MR-S } & \text { Mik } \\ \text { MR-SAM } & \text { Samarbetsministrarna } \\ \text { MR-U } & \text { Ministerrådet för Utbildning } \\ \text { NAMA } & \text { Nationally Appropriate Mitigation Action } \\ \text { NAPA } & \text { Nordens Institut på Grönland } \\ \text { NARIC } & \text { National Academic Recognition Information Cen- } \\ \text { NB8 } & \text { 1e European Union } \\ \text { NBCG } & \text { Nordic-Baltic Eight countries } \\ \text { NDF } & \text { Nordic Baltic Contact Group } \\ \text { NDPHS } & \text { Nordic Development Fund } \\ \text { NEF } & \text { Northern Dimension Partnership on Public Health } \\ \text { NEFCO } & \text { and Social Wellbeing } \\ \text { NeGI } & \text { Nordisk Energiforskning } \\ \text { NeIC } & \text { Nordic Environment Finance Corporation } \\ \text { NEPR } & \text { Nordic eScience Globalisation Initiative } \\ \text { NFTF } & \text { Nordic eInfrastructure Cooperation } \\ \text { NGO } & \text { Nordic Economy Policy Review } \\ \text { NHFÖ } & \text { Nordisk Film- och TV-fond } \\ \text { NHR } & \text { Non Government Organisation } \\ \text { NHV } & \text { Nordens Hus på Färöarna } \\ \text { NIAS } & \text { Nordiska Handikappolitiska Rådet } \\ & \text { Nordiska Hälsovårdshögskolan } \\ \text { NÄtitut för Asienstudier }\end{array}$


NIAS-Linc Nias Library and Information Centre

NIF Norden i Fokus

NIFIN Nordens Institut i Finland

NIfS Nordiskt Institut för Sjörätt

NIKK Nordisk Institutt for kunnskap om kjønn

NIOM Nordisk Institutt for Odontologiske Materialer

NIP $\quad$ Nordens Institut på Åland

Nordiska Institutionen för vidareutveckling inom

NIVA arbetsmiljöområdet

NKJ Nordiskt Kontaktorgan för jordbruksforskning

Nordisk arbetsgrupp för näring, matkultur och

NKMT toxikologi

Nordisk Arbetsgrupp fåor mikrobiologi och djur-

NMDD hälsa/djurvälfärd

Nordisk arbetsgrupp för Livsmedelsförvaltning

NMF och Konsumentinformation

NMKL Nordisk Metodikkomité for Levnedsmidler

NMP Nordic Master Programme

NMR Nordiska Ministerrådet

NMRS Nordiska Ministerrådets Sekretariat

NMN Nordiska Miljömärkningsnämnden

NNC Nordic Nias Council

NOMESKO Nordisk Medicinalstatistisk Kommitté

NOPEF

NORA

NOREY

Nordiska Projektexport Fonden

NORDBUK

NordGen

Nordiskt Atlantsamarbete

Nordens Hus i Reykjavik

Nordisk Barn och Ungdomskommitté

Nordisk Genresurs Center

Nordiskt Informationscenter för Medie- och

NORDICOM Kommunikationsforskning

NORDITA Nordiskt Institut for Teoretisk Fysik

Norsk Arbetstidskrift I litteratur och Kultur, den

NORDLIT Humanistiska fakultet, Tromsö Universitet

Nordregio Nordisk Center för Regional Utveckling

NORDVULK Nordiskt Vulkanologiskt Institut

NORIA Nordisk Forskning och Innovation 
NOSOSKO Nordisk Social-Statistisk Kommitté

NOS-M

Nordiskt samarbete för Medicin

NOS-N

Nordiskt samarbete för Naturvetenskap

NQF

N-REN

NR

Nordic Qualification Framework

NSI

Nationellt nätverk för forskning och utbildning

NSK

Nordiska Rådet

NSS

NSU

Nordiskt Samiskt Institut

NVC

Nordisk Samarbetskommitté

NVL

Nordiskt skolsamarbete

OECD

OESS

Nordiskt Sommaruniversitet

Nordens Välfärdscenter

Nätverk för vuxnas lärande

Organisation for Economic Cooperation and Development

$\mathrm{PhD}$

Open Europe Scholarship

PIIAC

Doctor of Philosophy

Program for the International Assessment of Adult Competencies

Arbetsgrupp under EK-U för "Samverkan, arbets-

SAK

SLCP delning och koncentration inom högre utbildning"

SLU

SNS

SME-bolag

SU

Short lived Climate Pollutants

Sveriges lantbruksuniversitet

Samnordisk Skogsforskning

SVANEN

Små och mellanstora företag

Stockholms Universitet

SVL

TEEB

TFI

Nordiskt miljömärke

Nordiskt samarbete om vuxnas lärande

The Economics of Ecosystems and Biodiversity

Topforskningsinitiativet

TIMMS and

PIRLS

UNEP

TIMMS - Trends in International Mathematics and Science Study /PIRLS - Progress in International Reading Literacy Study

UNECE

United Nations Environment Programme

ÄK/EK-xxx

United Nations Economic Commission for Europe Ämbetsmannakommitté/Embedsmandskommitté 
